\title{
BAKTERIORODOPSZIN ÉS KOENZIMEK FEMTOSZEKUNDUMOS IDŐFELBONTÁSÚ SPEKTROSZKÓPIAI VIZSGÁLATA
}

\author{
Ph.D. értekezés
}

\section{HEINER ZSUZSANNA}

\author{
TÉMAVEZETŐK: \\ Dr. Osvay Károly \\ Egyetemi docens \\ Szegedi Tudományegyetem, Optikai és Kvantumelektronikai Tanszék \\ Dr. Groma Géza \\ Tudományos fömunkatárs \\ MTA Szegedi Biológiai Kutatóközpont, Biofizikai Intézet
}

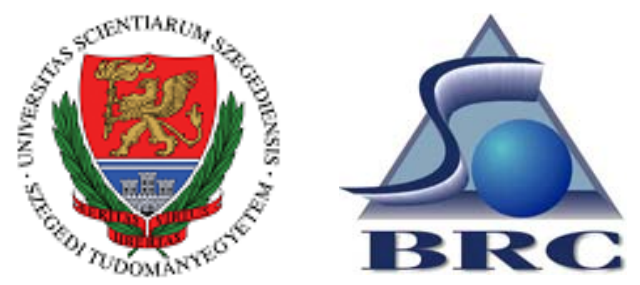

SZEGEDI TUDOMÁNYEGYETEM

Természettudományi és Informatikai Kar

Fizika Doktori Iskola

Szeged, 2013 


\section{TARTALOMJEGYZÉK}

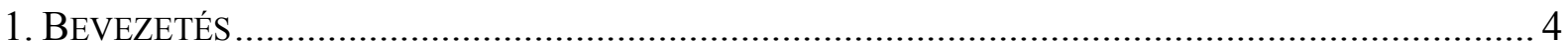

2. TUDOMÁNYOS ELÖZMÉNYEK............................................................................................. 7

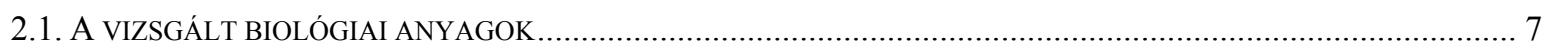

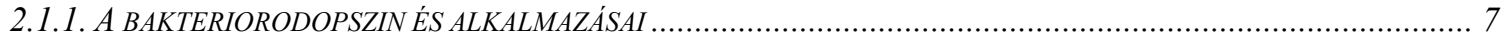

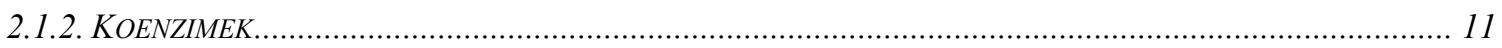

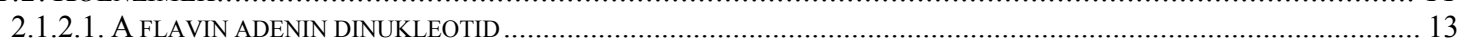

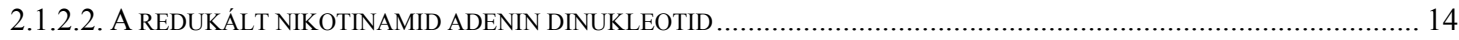

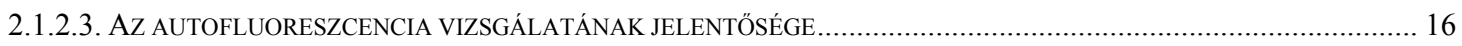

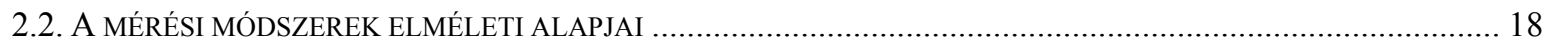

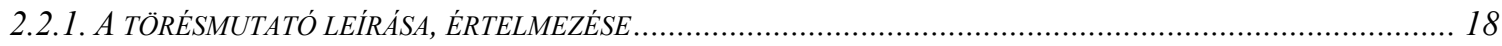

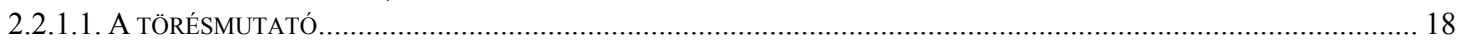

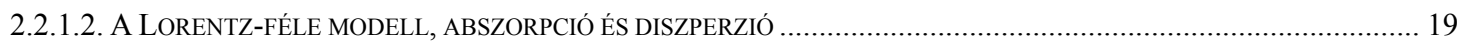

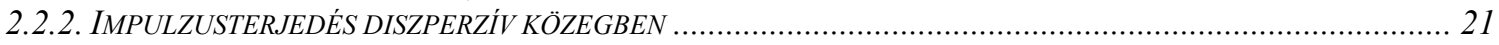

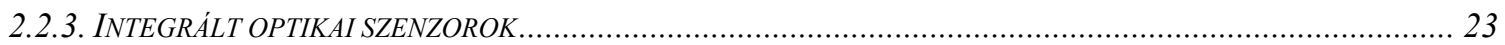

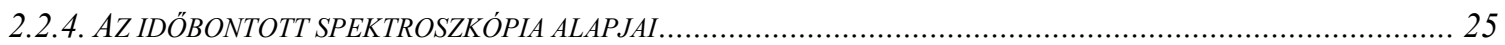

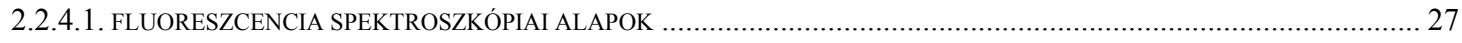

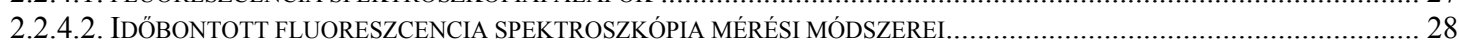

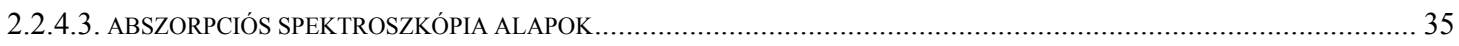

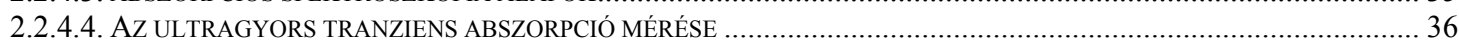

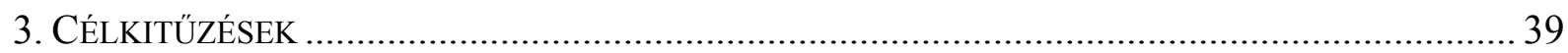

4. KíSÉRLETI ANYAGOK ÉS MÓDSZEREK ………………………………………………... 41

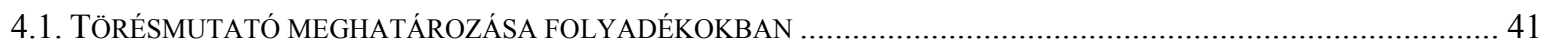

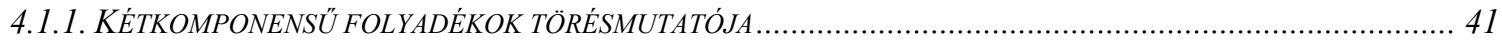

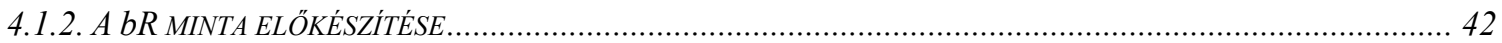

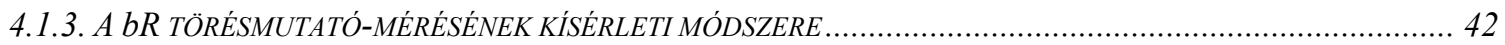

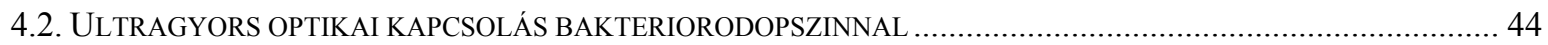

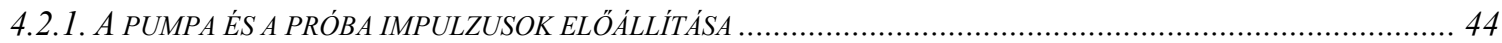

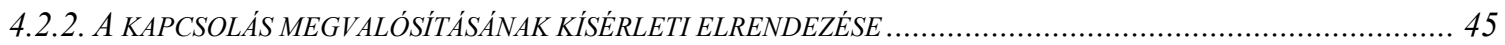

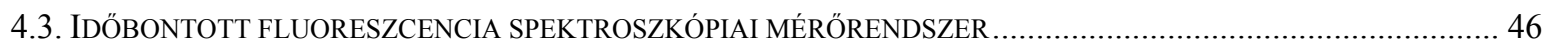

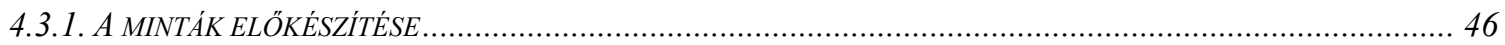

4.3.2. A FREKVENCIA KONVERZIÓN ÉS TCSPC TECHNIKÁN ALAPULÓ MÉRÉSEK TERVEZÉSE, KÍSÉRLETI

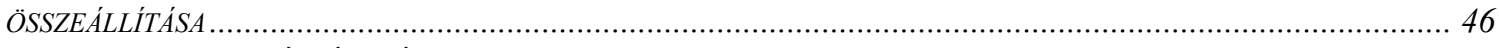

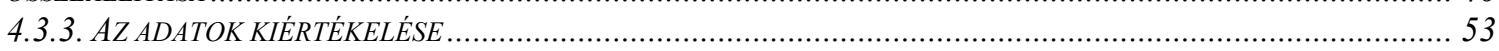

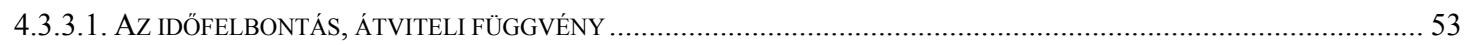

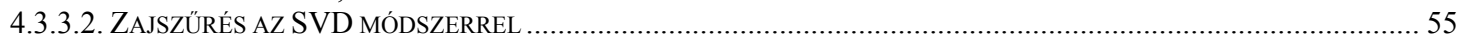

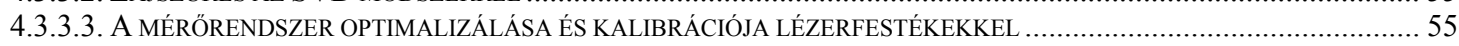

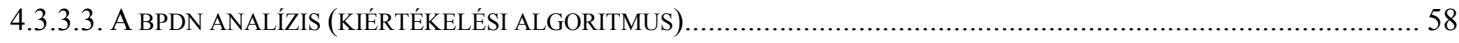

4.4. AZ ABSZORPCIÓKINETIKA MÉRÉSHEZ ALKALMAZOTT PUMPA-PRÓBA RENDSZER .................................. 61

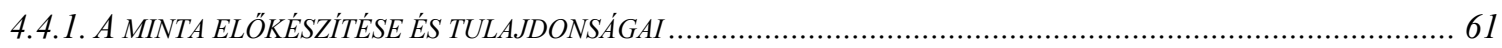

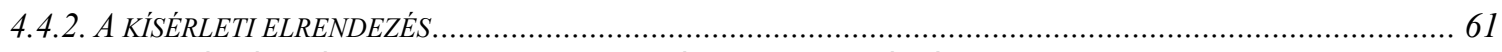

4.4.3. ADATKIÉRTÉKELÉS A TRANZIENS ABSZORPCIÓS SPEKTROSZKÓPIÁBAN.........................................63 


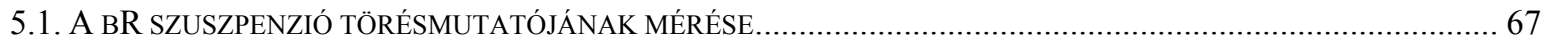

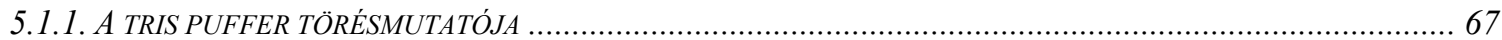

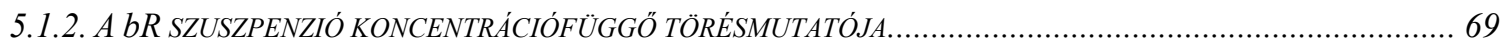

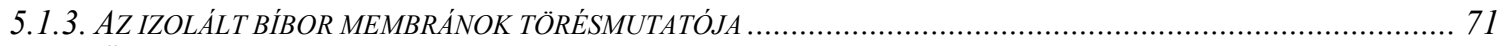

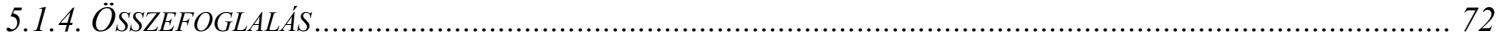

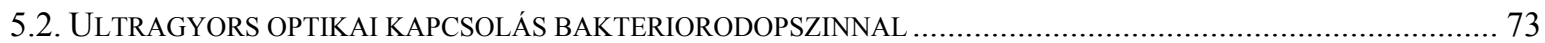

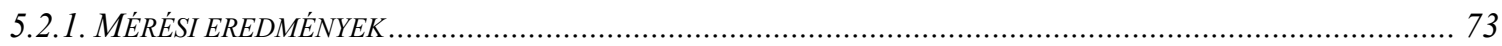

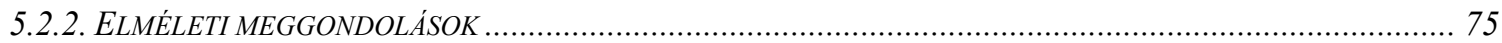

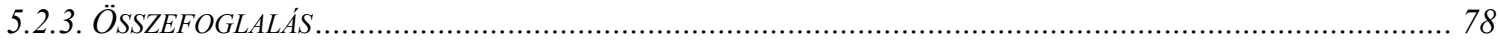

5.3. A FAD FLUORESZCENCIA KINETIKÁJÁNAK VIZSGÁLATA KÜLÖNBÖZÖ MIKROKÖRNYEZETEKBEN ………....... 80

5.3.1. A FAD FLUORESZCENCIÁJÁNAK MÉRÉSE KÜLÖNBÖZÖ MIKROKÖRNYEZETEKBEN ................................... 80

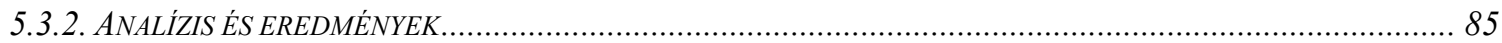

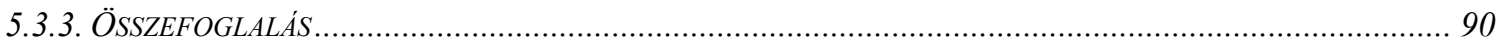

5.4. A NADH ABSZORPCIÓ KINETIKÁJÁNAK MÉRÉSE NYITOTT ÉS ZÁRT KONFORMÁCIÓBAN..............................92 92

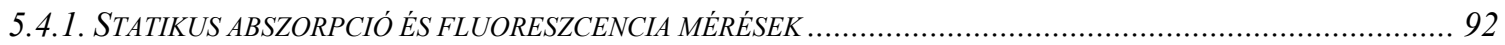

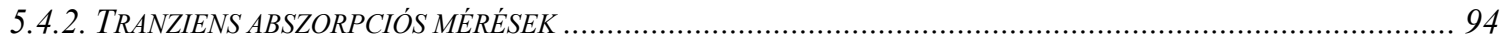

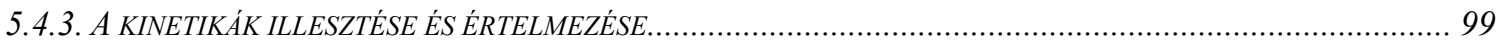

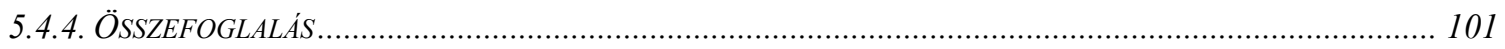

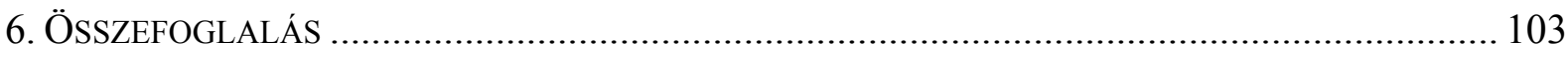

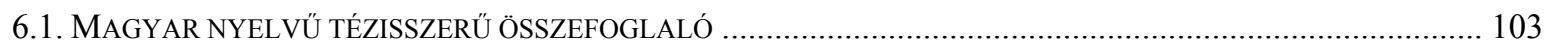

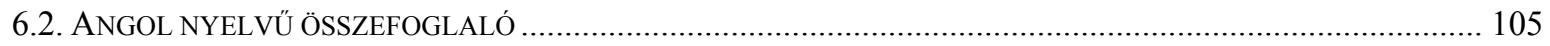

6.3. A TÉZISEK ALAPJÁT KÉPEZŐ SAJÁT KÖZLEMÉNYEK JEGYZÉKE ……................................................... 112

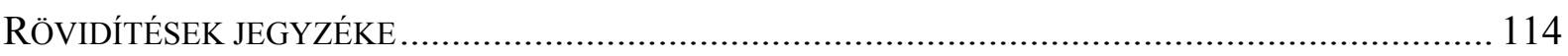

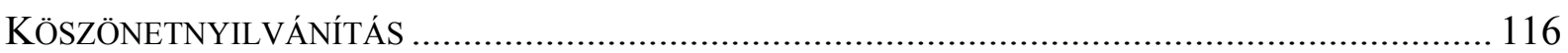

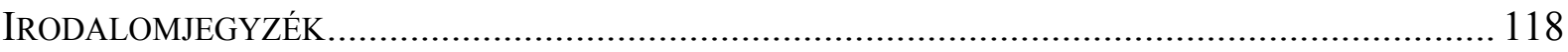




\section{BEVEZETÉS}

Az első lézer megépítésekor, 1960-ban új korszak kezdődött az optikában. A lézerek ezt követő rohamos fejlődése sok más területen is új tudományos eredményeket hozott, rendkívül sok alkalmazást tett lehetővé. Az alapkutatásokban azóta szinte napról-napra újabb eredményeket érnek el ezen eszközökkel, mint például az attoszekundumos impulzusok, lézeres gyorsítás, Bose-Einstein-kondenzáció terén. A mindennapi életben a lézerlemezjátszóktól a száloptikán alapuló fénytávközlésig, a traffipaxoktól a hologramokig, az orvosok munkaeszközein át gyakorta találkozhatunk a technika ezen vívmányaival.

Már az első lézerek megjelenésétől kezdve a kutatók érdeklődésének homlokterébe került a különböző módszerekkel előállított rövid lézerimpulzusok időtartamának csökkentése. Érthető ez a törekvés, hiszen a lézerek segítségével olyan időben, térben és spektrálisan egyaránt jelentős és szabályozható energia-kondenzációt sikerült elérni, amely addig mind az optikai, mind pedig a spektroszkópiai gyakorlatban ismeretlen volt.

Az ultrarövid impulzusok előállítása 1964-ben, a módusszinkronizálás felfedezésével kezdődött [1]. Húsz évvel később, 1984-ben felismerték, hogy a lézerrezonátoron belül elhelyezett prizmás kompresszor alkalmazásával a csoportsebesség-diszperzió csökkenthető [2-4], így az impulzushossz akár 27 fs-ra rövidíthető [5]. Manapság a rezonátorban ún. fázismodulált tükröket [6-8] és/vagy telítődő abszorbert használva [9] 3-4 fs impulzushossz is elérhető $[10,11]$. Sok alkalmazási terület azonban az oszcillátorokból nyerhetőnél lényegesen nagyobb energiákat igényel [12], ami az erősített ultrarövid impulzusok előállításának kutatását vonta maga után már a '70-es évek végétől kezdődően egészen napjainkig [13].

A legjelentősebb elörelépés ezen a területen a fázismodulált impulzuserősítés (chirped pulse amplification, CPA) felfedezése volt [14-16]. Ennek lényege, hogy az erősítendő impulzusok időbeli hosszát előbb megnyújtják, majd erősítés után összenyomják. Minderre azért van szükség, mert nyújtás nélkül az impulzusok intenzitása az erősítőben annyira megnőne, hogy roncsolná magát az erősítő kristályt, illetve maga az impulzus térben és időben nemkívánatos torzulásokat szenvedne - többek között az önfókuszálás, önfázismoduláció és következményei miatt. Megnyújtott időtartama, azaz lecsökkentett intenzitása miatt az így kapott fázismodulált impulzus már felerösíthető az optikai elemek roncsolásának veszélye nélkül. Ez történik meg a második lépésben. A már megerősített, de még nyújtott impulzust egy megfelelő kompresszorral össze kell nyomni közel az eredeti hosszára. 
Az ultrarövid impulzusok megjelenése és alkalmazása hozzájárult ahhoz, hogy a gyors folyamatok kutatásában az elektronikus eszközök feloldóképességének elvi határát (néhány pikoszekundum) sikerüljön áttörni. Ezen impulzusok $\geq 10^{10} \mathrm{~W} / \mathrm{cm}^{2}$ nagyságrendű intenzitása a fény-anyag kölcsönhatás kutatása terén már tanulmányozhatóvá tette a korábban megjósolt nemlineáris effektusokat. Ezzel új tudományterületek és spektroszkópiai alkalmazások egész sora jött létre. Az elmúlt 15-20 évben nagyon aktív és eredményes kutatások zajlottak a femtobiológia és femtokémia témakörben, melynek köszönhetően az ezen új diszciplínák létrejöttében közremüködő interdiszciplináris közösség egyik jeles vezetőjét, Ahmed $\mathrm{H}$. Zewailt 1999-ben kémiai Nobel-díjjal tüntették ki [17-19]. Ö olyan, ún. pumpa-próba mérési eljárást fejlesztett ki, amellyel femtoszekundumos időskálán követhető a kémiai-biológiai reakciók lefolyása, vagyis az atomok molekulán belüli mozgása, miközben azok a reagáló molekulákban átrendeződnek. Útnak indítva mindezzel a femtoszekundumos spektroszkópia irányvonalát.

Munkám során ultrarövid lézerimpulzusok spektroszkópiai alkalmazásával foglalkozom. Részben femtoszekundumos oszcillátorok nJ energiájú impulzusait használtam, részben pedig $\mathrm{mJ}$ energiára erősített impulzusokat, ahogy az aktuális pumpa-próba kísérlet megkövetelte. Értekezésem két fó alkalmazási területre osztható. Az egyik a bakteriorodopszin membránfehérje vizsgálata és lehetséges alkalmazása az optikai távközlésben, a másik pedig a flavin adenin dinukleotid és a redukált nikotinamid adenin dinukleotid koenzimek ultragyors időbontott spektroszkópiai vizsgálata. Mivel e koenzimek a sejtek energiatermelő folyamataiban (energiatranszport láncban) vesznek részt, vizsgálatukon keresztül többek között a sejtek metabolikus állapota is tanulmányozható.

Dolgozatomban először röviden áttekintem a tudományos előzményeket. Bemutatom a kísérleteim során használt biológiai anyagokat - a bakteriorodopszin, a flavin adenin dinucleotid és a redukált nicotinamid adenin dinucleotid -, kitérve a technikai alkalmazási lehetőségekre, illetve kutatásuk jelentőségére. Ezután összefoglalom az ultrarövid impulzusok terjedését, a hullámvezetők müködését, az abszorpciós és fluoreszcencia spektroszkópiai módszerek alapjait, illetve az ehhez szorosan kapcsolódó definíciókat, az elekrodinamikai és nemlineáris optikai vonatkozásokat. A következő fejezetben a tudományos előzmények ismeretében megfogalmazom célkitüzéseim. A negyedik fejezetben ismertetem az alkalmazott kísérleti eszközöket valamint mérési módszereimet. Bemutatom az általam használt lézerek, 
lézerrendszerek főbb paramétereit, kitérek a konkrét kísérleti elrendezésekre, a kísérletek során használt biológiai anyagok előkészítésére, a mérési adatok kiértékelésére. Az ötödik fejezetben részletesen ismertetem új tudományos eredményeim. Végezetül pedig magyar majd angol nyelven tézisszerü összefoglalást adok eredményeimről.

Méréseimet a Szegedi Tudományegyetem Optikai és Kvantumelektronikai Tanszékén (TeWaTi Kutatócsoport), a Magyar Tudományos Akadémia Szegedi Biológiai Kutatóközpont Biofizikai Intézetében (Femtobiológiai laboratórium), valamint a strasbourgi CNRS IPCMS, Département d'Optique ultrarapide et de Nanophotonique (BIODYN Kutatócsoport) lézerlaboratóriumaiban végeztem el. 


\section{TUDOMÁNYOS ELŐZMÉNYEK}

\subsection{A VIZSGÁlt BIOLÓgIAI ANYAGOK}

E fejezetben összefoglalom az általam vizsgált biológiai anyagok föbb tulajdonságait, fizikai paramétereit, bemutatom mind a bakteriorodopszint, mind pedig a koenzimeket részletesen. Külön kiemelem, miért fontos e biológiai anyagok kutatása, müködésük illetve szerepük tanulmányozása.

\subsubsection{A BAKTERIORODOPSZIN ÉS ALKALMAZÁSAI}

Az archeák doménjébe tartozó halobaktériumok, így a Halobacterium salinarum is a magas sótartalmú, napfényben gazdag vizek lakói, nagy mennyiségben találhatóak meg például tengermelléki sólepárló medencékben [20]. A nagyjából $0.5 \mu \mathrm{m}$ átméröjü és 4-10 $\mu \mathrm{m}$ hosszúságú, pálcika alakú sejt helyváltoztatásához csillókat használ. Sejtfalát szabályos, hexagonális rácsba rendeződött $200 \mathrm{kDa}$ molekulasúlyú glikoprotein és kevés szénhidrát alkotja. Ez a fal veszi körül a lipidekböl felépülő, pigmentált sejtmembránt.

Kiderült, hogy a baktérium sejtmembránjában a szemben található rodopszin nevü molekulához nagyon hasonló fehérje található (1. ábra), melyet bakteriorodopszinnak (bR) neveztek el [21]. Szerepe - a fotoszintéziséhez hasonlóan - a napfény energiájának átalakítása biokémiai energiaformává [22]. Az utóbbi évek genetikai vizsgálatai alapján kiderült, hogy egy igen közönséges baktérium (SAR 86) is tartalmaz egyfajta rodopszint. A részletesebb vizsgálat megállapította, hogy ennek szerepe szintén a napfény energiájának hasznosítása [23]. E baktérium igen nagy mennyiségben van jelen valamennyi tengerben, óceánban, ami azt jelenti, hogy a földi napfényenergia hasznositásában sokkal nagyobb a rodopszinok szerepe, mint azt korábban gondoltuk.

Egyszerü kezelhetősége miatt a Halobacterium salinarumnak - illetve ezen belül is elsősorban membránfehérjéjének, a bakteriorodopszinnak - a kutatásával nagyszámú biológus illetve biofizikus foglalkozik. Mivel a kísérletek során a molekula számos gyakorlati alkalmazhatóságára is fény derült, manapság a bR a biotechnológiában ill. biofotonikában is népszerú molekulává vált.

A bR-re elöször biológiai alapkutatások során figyeltek fel. Ez a rendszer sokkal egyszerübb, mint akár a kloroplasztisz, akár bármely más ismert biológiai energiaátalakító rendszer, így sokkal könnyebben tanulmányozható [22]. Az ehhez hasonló egyszerü 
rendszerek megismerése a biológiában számtalanszor jelenti az első lépést a komplexebb rendszerek feltérképezésében.

A bR fehérjemolekula hét alfa-hélixböl (1.a ábra, $A, B, \ldots G$ betűkkel jelölve) és körülbelül 250 aminosavból áll [24]. A fehérjék a sejt felületén szabályos hexagonális kristályszerkezetet alkotnak [25], ezek az úgynevezett bíbormembrán foltok, amelyek akár a sejt teljes felületének 50\%-át is elfoglalhatják. A fehérje bíbor színét egy hozzá kapcsolódó kromofór, a retinál adja. (A retinál közönséges festékanyag, tulajdonképpen az A-vitamin egyik alapja). A fehérjemüködés során fény hatására proton pumpálódik a sejt belsejéből az extracelluláris térbe, az így létrejött elektrokémiai gradiens később a sejt számára az élethez szükséges energiává alakul [21,26].

A fehérje belsejében egy retinál molekula található, amely a 216-os számú lizin oldallánchoz kapcsolódik protonált Schiff-bázison keresztül (1.a ábra). A retinál egy foton elnyelése hatására izomerizálódik, a Schiff-bázis protonja különböző, funkcionális szempontból aktív csoportokon keresztül a sejten kívüli térbe jut, majd a retinál a membrán belseje felöl reprotonálódik és a fehérje újra alapállapotba kerül, készen egy újabb ciklusra. A proton transzlokációja során a fehérje különböző konformációs állapotokon megy keresztül, amelyek spektroszkópiailag jól elkülöníthetők egymástól, amint ezt az 1.b ábra mutatja.

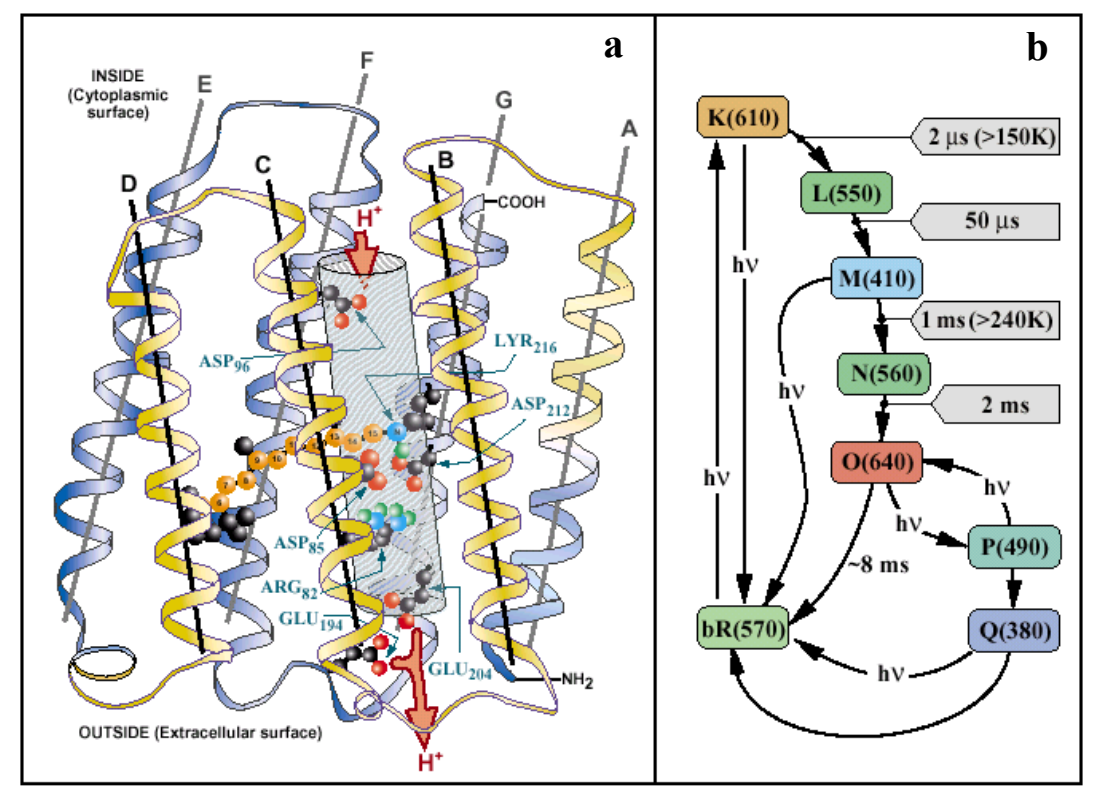

1. ábra - A bR szerkezete (a), valamint fotociklusa (b) [27]

Ezen állapotok sorozatát hívjuk fotociklusnak (1.b és 2. ábra):

$$
\mathrm{BR}_{570} \rightarrow \mathrm{I}_{460} \rightarrow \mathrm{J}_{625} \rightarrow \mathrm{K}_{610} \rightarrow \mathrm{L}_{540} \rightarrow \mathrm{M}_{410} \rightarrow \mathrm{N}_{550} \rightarrow \mathrm{O}_{630} \rightarrow \mathrm{BR}_{570}
$$


A betük az alap és a köztes állapotokat jelölik, az indexek pedig az abszorpciós maximumok hullámhosszát nm-ben. Minden köztes állapot is fényérzékeny [28, 29], azaz megfelelő hullámhosszúságú fénnyel történő második gerjesztés után a molekula rövid időn belül visszatér az alapállapotba $\left(\mathrm{BR}_{570}\right)$.

A fentiek miatt a bR-t gyakran nevezik ,optikailag programozható” anyagnak [27]. Optikai minőségü vékonyrétegeket is gyakran készítenek belőle, amit a bioelektronikai ill. fotonikai alkalmazásokban használnak. Ezekben a szárított bR mintákban például a fotociklus $\mathrm{M}$ utáni állapotokat nem tartalmaz, így közvetlenül M-böl cseng le a $\mathrm{BR}_{570}$ alapállapotba. $\mathrm{Az}$ egyes állapotok élettartama (2. ábra) néhány száz fs-tól $(B R \rightarrow I \rightarrow J)$ több száz ms-ig tart $(\mathrm{M}$ $\rightarrow \mathrm{BR})[30,31]$.

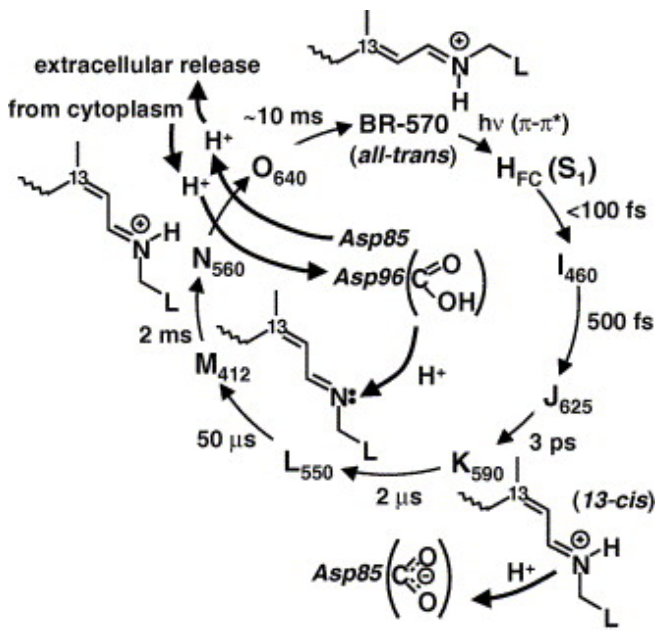

2. ábra - A bR fotociklusa az átmeneti időállandókkal [32]

A fotokémiai reakciókkal együtt jár az abszorpció változása, így a törésmutató is megváltozik a Kramers-Kronig-relációnak (ld. 2.2.1.2 fejezet) megfelelöen [33, 34], melyeket a 3.a és $b$ ábrákon mutatok be.
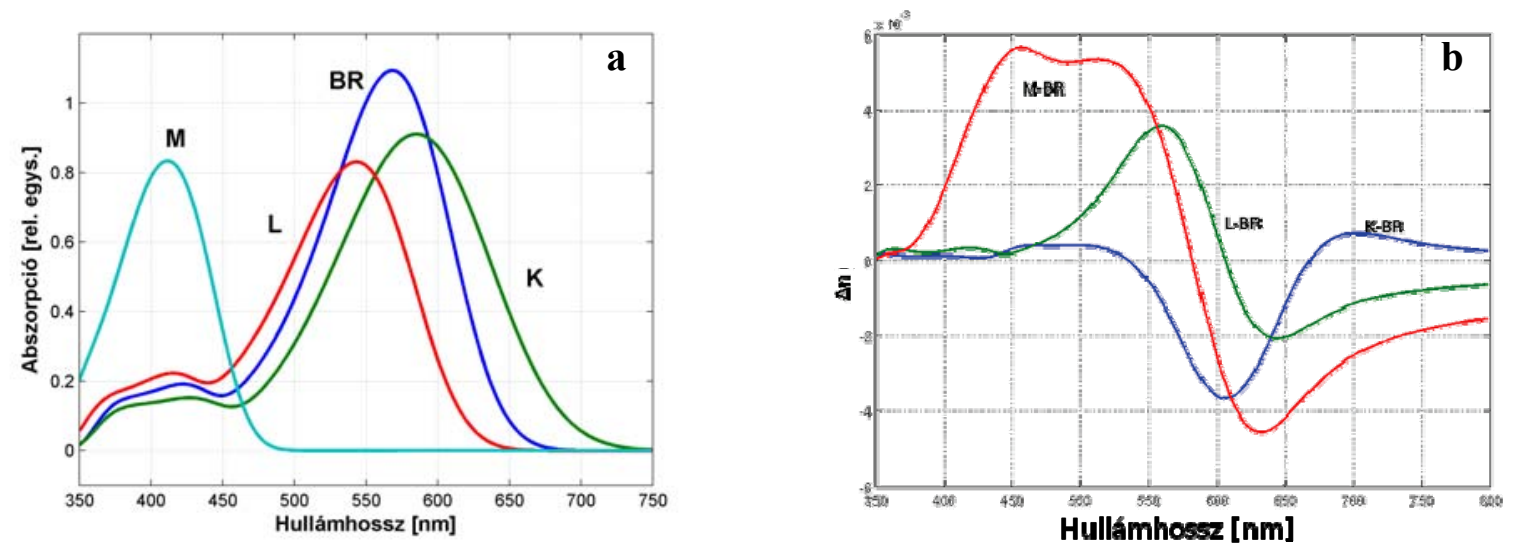

3. ábra - A bR abszorpciós spektrumai (a) és törésmutatójának változása (b) a különböző konformációs állapotokban [35] 
A bioelektronikában rögtön felismerték ezen optikai tulajdonságok perspektíváját. Napjaink kommunikációs hálózatainak adatforgalma és sebessége folyamatosan növekszik, jelenleg az 1 Tbit/s-os hálózat képviseli az elvárt sebességet és adatátviteli kapacitást. Általános vélemény, hogy a teljesen optikai adatátvitel az egyik legígéretesebb irány e cél eléréséhez. Az integrált optikai fejlesztések egyik kulcskérdése egy olyan, megfelelő nemlineáris optikai (NLO) tulajdonságokkal rendelkező anyag megtalálása, ami aktív szerepet tölthet be az integrált optikai áramkörökben. Erre a célra mindezidáig folyadékkristályokat, illetve félvezető anyagokat használtak, melyek azonban nem váltak be maradéktalanul. A legfrissebb kutatások szerint sokoldalú és költséghatékony megoldást jelenthetnek erre a célra a szerves, $\pi$-konjugált anyagok a jelenleg alkalmazott szervetlen, félvezető anyagok helyett [36-38]. A szerves anyagok ugyanis magas (harmadrendű) polarizálhatósággal rendelkeznek, ráadásul kétfoton-abszorpciós veszteségek nélkül. Ezekkel azonban problémák adódtak, mivel a folyadékkristályok nem rendelkeznek elegendően nagy fényindukált törésmutató-változással, a szerves kémiai úton előállítható $\pi$-konjugált anyagok fejlesztése és az optikai felhasználás szempontjából történő optimalizálása pedig még hosszabb időt vesz igénybe ${ }^{1}$. A természet által készen „kínált” $\pi$-konjugált anyagnak, a bakteriorodopszinnak viszont amellett, hogy más optikai anyaggal összemérhető az indukált törésmutató-változása, a stabilitása is megfelelő, sőt szárított réteg formájában akár évtizedekig megőrzi funkcionalitását. Emellett gyakorlatilag tetszőlegesen sokszor újragerjeszthető, genetikai módosításokkal különböző tulajdonságai - például az egyes állapotok lecsengési ideje - széles határok között változtathatóak, így kinetikailag is igen jól tervezhetö [39].

Mindezek miatt a bR-t az integrált optikában, de számos más helyen is igen változatos módon alkalmazzák. A bR segítségével például optikai kapcsoló építhető [40], ami a bR fényindukált törésmutató-változását használja ki. A publikációk egy része a fehérje fotoelektromos tulajdonságainak felhasználását tárgyalja [41], illetve számos szabadalom alapul azon, hogy a bR polarizációs hologramok rögzítésére képes, ezáltal dinamikus, optikai adattároló eszközök alapját képezheti a jövőben [42, 43]. A fentieken kívül számos publikáció jelent meg a bR egyéb felhasználási lehetőségeiről: UV szürőként, optikai teljesítményhatárolóként is alkalmazható [44], valamint nemlineáris optikai tulajdonságainak felhasználása révén másodharmonikus keltésére is alkalmas lehet [45-48].

Az elektronikában ismert kapcsolók pontosan úgy befolyásolják az elektromos jeleket, mint az előző bekezdésben megismert szerkezet a fényjeleket. Ezzel a módszerrel a bR-nek

\footnotetext{
${ }^{1}$ Jóllehet ez az élettartam néhányszorosára növelhető alacsony hőmérséklet, illetve extrém alacsony páratartalom mellett, de ezeket a körülményeket a gyakorlati alkalmazás során nehéz létrehozni.
} 
akár teljesen optikai úton müködő chipek létrehozásában is kulcsszerepe lehet. Sokkal valószínübb azonban, hogy az optikai számítógépek helyett csak a továbbra is elektromos úton müködő chipek közötti kommunikációban fogják felváltani a fényjelek az elektromos jeleket. Ennek elsődleges oka, hogy a számítógépekben ma az adatfeldolgozás szük keresztmetszetét nem a mikroprocesszor, hanem az adatbuszok jelentik, így ezek gyorsítása segítheti a teljesítmény további növelését. Mivel az elektromos jeltovábbítás sebessége és a távolsága a tudományos-technikai határ közelében van, az egyik megoldást a tisztán optikai jeltovábbítás jelentheti [49]. A nagysebességü internet kapcsolatokhoz már manapság is fényjeleket használnak, melyek optikai szálakban haladnak. Komoly kutatások folynak többek között az Intel-nél is - olyan módszerek kidolgozására, amellyel az optikai jelátvitelt a számítógép chipjeinek, memóriájának és háttértárjainak kommunikációja során is alkalmazzák [50].

\subsubsection{KOENZIMEK}

Nagyon sok enzim összetett fehérje, így müködésükhöz egy nem fehérje természetű molekula szükséges, amit koenzimnek nevezünk. A koenzimek kis molekulatömegü, eltérő kémiai karakterü szerves vegyületek, amelyek egyes esetekben fémiont is tartalmaznak. Az enzimfehérjéhez kémiai kötésekkel kapcsolódnak. Ezek a kötések nagyon különbözők lehetnek (pl. H-hidak, ionos, kovalens kötések).

Azok a koenzimek, amelyek gyenge kémiai kötésekkel kapcsolódnak az enzimfehérjékhez disszociábilisak. A reakció végén a koenzim disszociál az enzimröl és egy második reakcióban, amelyet egy másik enzimfehérje katalizál alakul vissza a kiindulási formává, vagyis regenerálódik. Ilyen koenzimek például a hidrid anion átvitelben szerepet játszó nikotinamid adenin dinukleotid (NAD) vagy az egyszénatomos intermedierek szállításában közremüködő tetrahidrofólsav $\left(\mathrm{FH}_{4}\right)$ [51, 52].

Bizonyos koenzimek szorosan kapcsolódnak az enzimfehérjékhez, és a katalitikus ciklust követően nem válnak el az enzimtől. Az enzimfehérjéhez szorosan kapcsolódó koenzimet prosztetikus csoportnak nevezzük. Ilyen prosztetikus csoport például az elektrontranszport láncban szerepet játszó flavin adenin dinukleotid (FAD) vagy a transzaminálási reakcióban résztvevő piridoxálfoszfát [51, 52].

A legtöbb koenzimet a sejt az intermedier anyagcserében vitaminokból állítja elö. Sok vitaminnak biokatalítikus szerepe van: a vitamin maga a koenzim illetve a koenzim 
előanyaga. Vannak olyan vitaminok, amelyek antioxidáns hatásukkal a szervezet redox homeosztázisát befolyásolják, mások viszont hormonszerü hatással rendelkeznek. Megkülönböztetünk vízoldékony és zsíroldékony vitaminokat. A vízoldékony vitaminok többnyire koenzimek, a zsíroldékony vitaminok nem koenzimek, hanem más úton befolyásolják az anyagcsere folyamatokat (pl. A-vitamin-rodopszin-retinál kapcsolat) [52].

Munkám során az energiatranszport láncban résztvevő koenzimek, a NAD és a FAD időbontott spektroszkópiai vizsgálatával foglalkoztam. Az általam vizsgált koenzimek főszerepet játszanak a sejtek energiatermelö folyamataiban oly módon, hogy a kémiai energiát hasznos metabolikus energiává alakítják át [51]. A mitokondrium belső membánjában az elektrontranszport (légzési) lánc enzimei végzik az oxidatív foszforilációt (4. ábra). A légzési lánc működése során protonokat pumpál az intermembrán térbe. A $\mathrm{p}^{+}$gradienst tovább erősíti, hogy az $\mathrm{O}_{2}$ redukciója során víz keletkezik, ami további $2 \mathrm{H}^{+}$-nal csökkenti a belső térben a protonkoncentrációt. Az így kialakuló proton gradiens működteti a protontranszporttal kapcsolt ATP szintázt, amely a nagy energiájú foszfát kötéssel rendelkező ATP (adenozin trifoszfát) molekulát hozza létre. Ezt az összefüggő hálózatot szokták sejt légzésnek is nevezni, ami olyan ATP termelö folyamat, amiben a végső elektron akceptor valamilyen szervetlen molekula. A légzési lánc nagyon hatékony: minden pár elektron a NADH-ban 2.5 mol ATP szintéziséhez elegendő energiát hordoz, a FADH pedig 1.5 mol ATP-hez elegendőt.

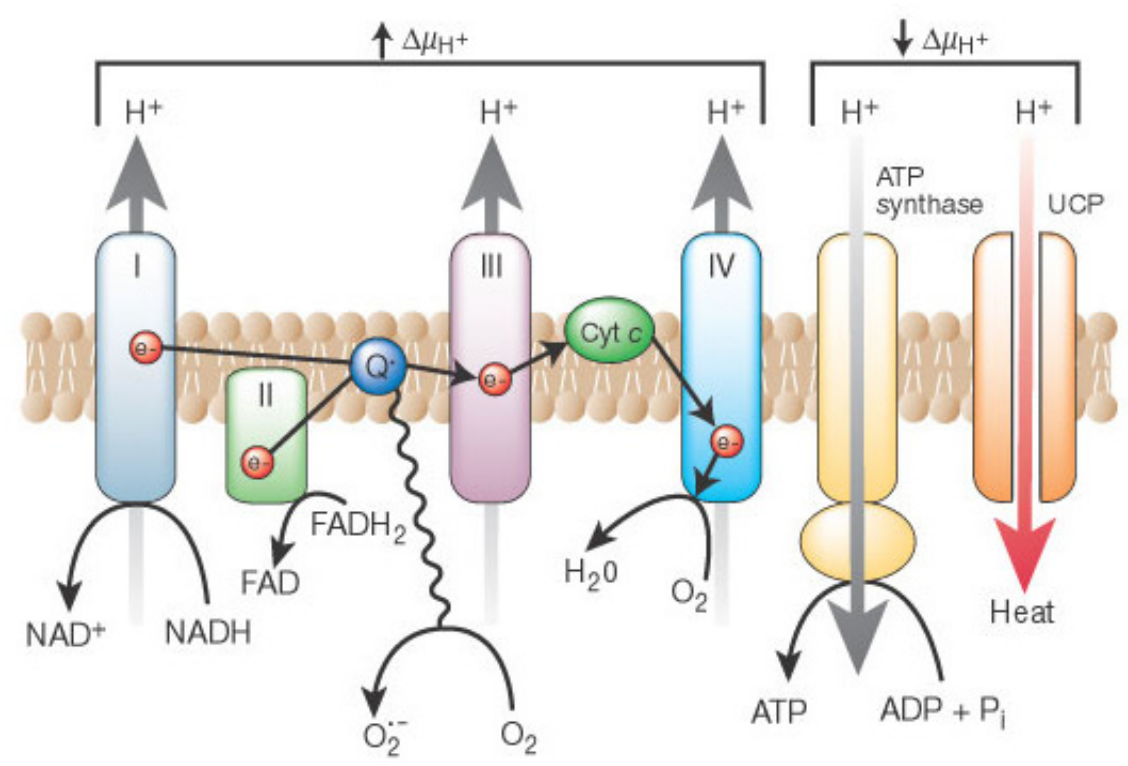

4. ábra - A mitokondrium energiatranszportjának sematikus rajza [53] 


\subsubsection{A FLAVIN ADENIN DINUKLEOTID}

A flavin adenin dinukleotid egy redox kofaktor, amely számos fontos reakcióban vesz részt a sejtek metabolizmusában [51, 52]. A FAD két különböző állapotban létezhet, amelyek az elektron(ok) befogadásával (akceptor) vagy átadásával (donor) különböznek egymástól. A molekula riboflavint (B2-vitamin) tartalmaz, amely az ADP (adenozin difoszfát) molekula foszfát csoportjához kapcsolódik Az izoalloxazin csoport ribitolhoz kötött szén-nitrogén kötéssel (ld. 5. ábra).

A FAD (oxidált vagy kinon forma) 2 elektront és 2 protont megkötve $\mathrm{FADH}_{2}$-vé (redukált vagy hidrokinon forma) alakul. E két forma abszorpciós spektrumában is különbözik egymástól.

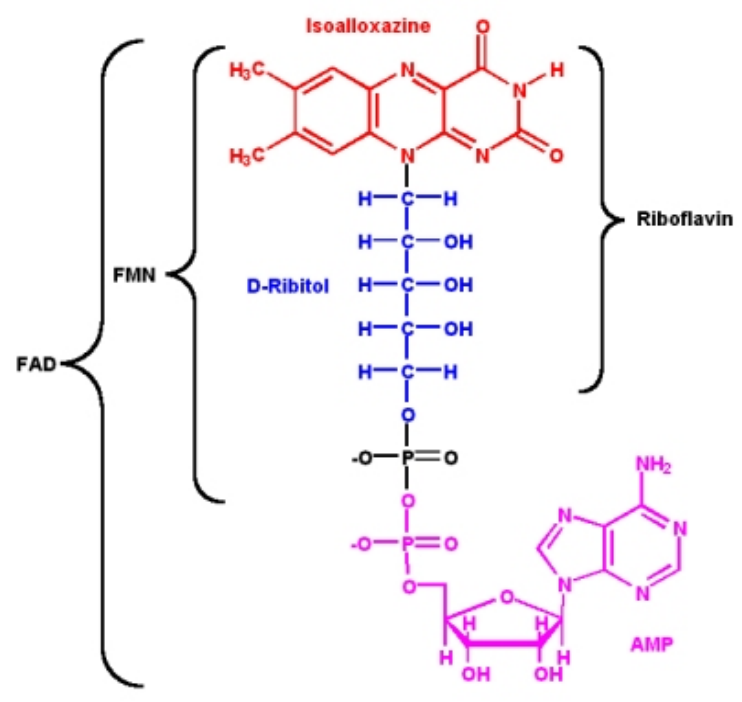

5. ábra - A FAD molekula kémiai struktúrája [54]

A FAD abszorpciós csúcsa $440 \mathrm{~nm}$ körül van, míg fluoreszcencia maximuma $530 \mathrm{~nm}$ (6. $a$ ábra). A molekula két aromás gyürüjéből (5. ábra) az izoalloxazin csoport fluoreszkál, az ADP csoport nem. Az ún. nyitott konformációs állapotban a két csoport távol van egymástól, ilyen esetben a fluoreszcencia életidő a nanoszekundumos tartományba esik. Ezzel szemben az összehajtott (stacked) konformációban (pl. vízben) az ADP csoport közel kerülve az izoalloxazinhoz kioltja annak fluoreszcenciáját, melynek eredményeképpen az életidő ps-os értékekre csökken $[55,56]$. A zárt formában a rövid lecsengés a gyors intramolekuláris elektron transzferből származik az adenin és a gerjesztett izoalloxazin csoportok között. A két konformációra azonos abszorpciós és fluoreszcencia spektrum jellemző, jelezve, hogy csak a fluoreszcencia élettartam érzékeny az izoalloxazin kromofór körüli környezetre. Az 
irodalomban fellelhető fluoreszcencia életidő mérések jellemzője, hogy egy-egy szük időablakra korlátozódnak és nem vizsgálják a fluoreszcencia teljes (100 fs - 10 ns) időtartományát. A különböző oldószerek, a hőmérséklet, a viszkozitás, pH, stb. erős hatással lehet a FAD konformációs szerkezetére, amelyeket az eddigi tanulmányok során szintén nem vizsgáltak. Az irodalomban található összehasonlító vizsgálatok szerint a szabad FAD-ra 2-3 ns körüli lecsengés jellemző, egyes fehérjékhez kötött formában az életidő 10-100 ps tartományba kerül [57] (6. b ábra).
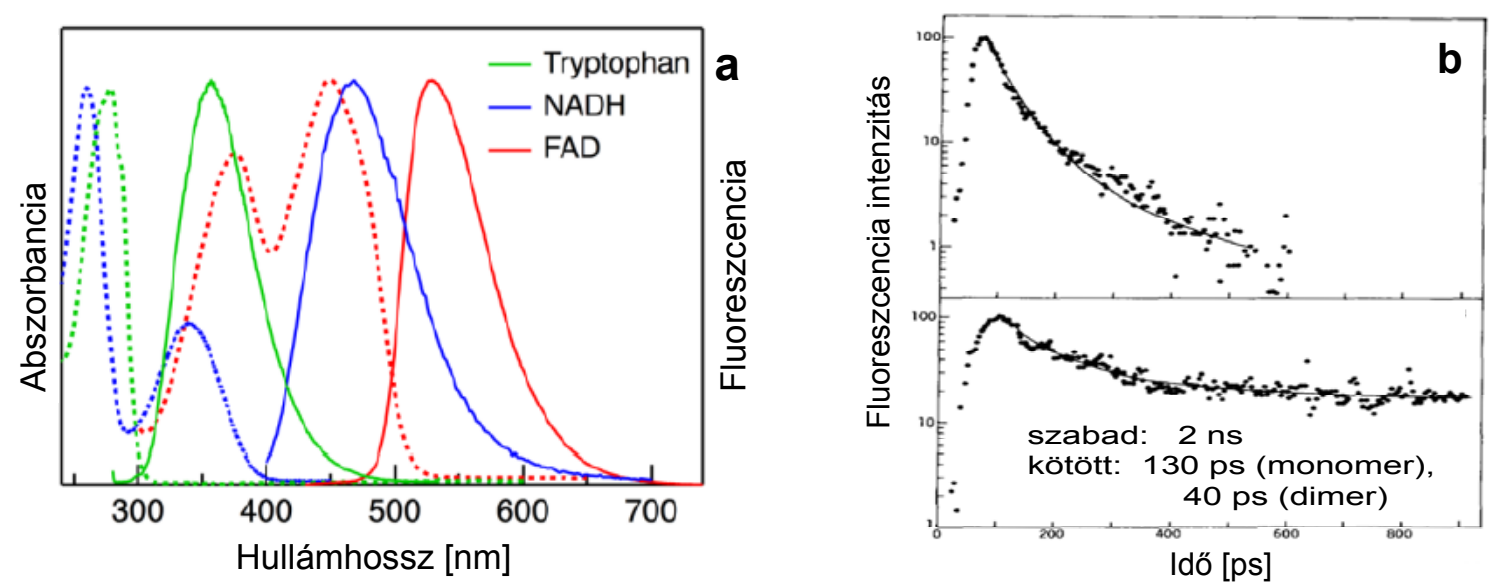

6. ábra - (a) A FAD és NADH abszorpciós (szaggatott vonal) és fluoreszcencia (folytonos vonal) spektruma [58] (b) a szabad és kötött FAD fluoreszcencia életideje [57]

\subsubsection{A REDUKÁLT NIKOTINAMID ADENIN DINUKLEOTID}

A nikotinamid adenin dinukleotid $(\mathrm{NAD}+$ ), valamint a foszforilált és redukált formája, a $\mathrm{NADP}^{+}$, a NADH és a NADPH, szintén központi szerepet játszik a sejtek anyagcseréjében és energiatermelésében, úgymint a hidrid-akceptor és donor-hidrid koenzimek [51, 52]. Az intracelluláris NADH két formában létezik, az egyik a szabad, a másik a különböző fehérjékhez kötött NADH.

A NADH két kromofórt tartalmaz (7. ábra), az egyik az adenin, a másik pedig a dihidronikotinamid, melyek abszorpciós maximumai 260 illetve 340 nm (6. a ábra, kék, szaggatott vonal) [59]. A különböző oldószerek, a hőmérséklet, a viszkozitás, stb. erős hatással lehet a NADH konformációs szerkezetére [60, 61]. A fluoreszkáló csoport a dihidronikotinamid (emissziós maximum $460 \mathrm{~nm}$ ), amely vagy direkt módon, vagy az adenin csoport abszorpcióját követő hatékony fluoreszcencia rezonancia energia transzfer (FRET) 
útján gerjeszhető. Utóbbi feltétele, hogy a molekula zárt konformációs állapotban legyen [59]. A metanol $(\mathrm{MeOH})$ jelenléte a nyitott konformációs állapotnak kedvez, így csökkenti a FRET lehetőségét a két kromofór között. A NADH oxidált formája $\left(\mathrm{NAD}^{+}\right)$nem-fluoreszcens.
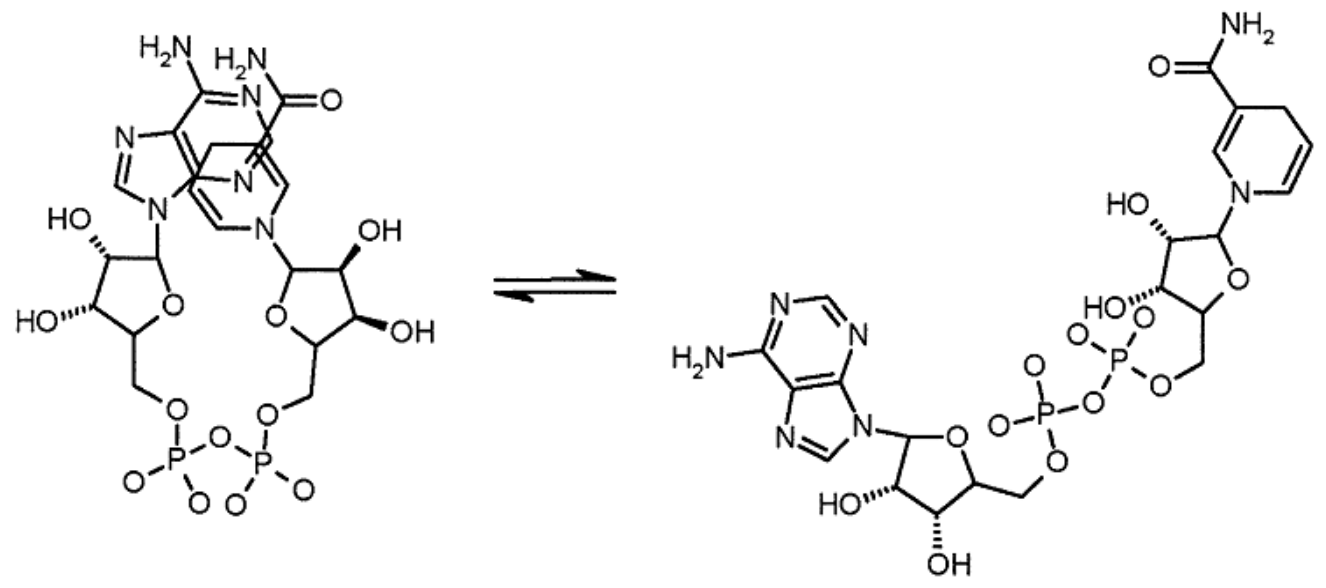

7. ábra - A NADH zárt és nyitott konformációban [59]

A szabad NAD(P)H gerjesztett állapotának életideje 0.4 ns, azonban fehérjéhez kötött formában az életidő egy nagyságrenddel nagyobb, 1-3 ns körüli (8. ábra) [62]. A két forma aránya erősen függ a mikrokörnyezettől, így - mint azt a következő fejezetben részletesen bemutatom - a fluoreszcencia életidő mérésével jól jellemezhető a sejt anyagcseréjének állapota. Ugyanakkor abszorpció kinetikai méréseket a molekula konformációjának változására vonatkozóan eddig még nem közöltek az irodalomban.

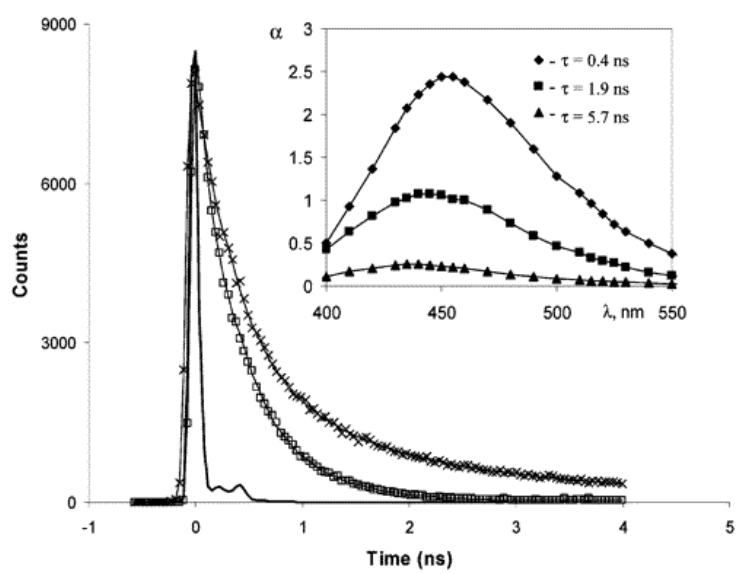

8. ábra - A szabad és kötött NADH fluoreszcencia kinetikája. A folytonos fekete vonal a rendszer átviteli függvénye, a belső ábra pedig a három exponensből álló illesztés amplitudó spektruma [62]. 


\subsubsection{AZ AUTOFLUORESZCENCIA VIZSGÁLATÁNAK JELENTŐSÉGE}

A rugalmas szórás, a fluoreszcencia, a foszforeszcencia és a Raman spektroszkópia bőven tartalmaznak a szövetek biokémiai és morfológiai összetételét illetően olyan információkat, amelyek tükrözik a betegségek jelenlétét és stádiumát a szövetekben [63, 64]. Az idő- és hullámhosszbontott fluoreszcencia spektroszkópiát a 2000-es évektől kezdve gyakran kombinálják képalkotó eljárásokkal (pl. fluorescence lifetime imaging - FLIM, Förster resonant energy transfer - FRET), hogy képalkotással egybekötve mérjék a fluoreszcencia jeleket szabad és kötött koenzimek (NADH és FAD), valamint például melanin, kollagén, elasztin, porfirin esetében, amelyek erős ún. autofluoreszcenciát (biológiai struktúrák természetes fényemissziója, natural fluorescence) mutatnak.

A spektrálisan bontott fluoreszcencia életidő diagnosztika új lehetőséget teremtett, hogy megkülönböztethessük a sejttípusokat a bennük felhalmozódott kromofórok alapján. Ily módon lehetőség van ,in vivo” feltárni fluoreszkáló aminosav oldalláncok (tirozin, triptofán, fenilalanin), a szerkezeti fehérjéknek (elasztin, kollagén) vagy akár néhány koenzim jelenlétét. A NADH erősen fluoreszkál, azonban elveszti e képességét az oxidációja során. A FAD esetében ez épp fordítva történik, az oxidált formájában képes fluoreszkálni [55, 65]. Számos kutató kimutatta, hogy amikor a közeli UV tartományban gerjesztjük a szöveteket, tumorszövetben az endogén fluoreszcencia $500 \mathrm{~nm}$ körül lecsökken a normális környező szövetekhez viszonyítva [66]. Az eltérések az oxidált állapotú flavinok és a redukált NADH relatív mennyiségének csökkenéséből eredhetnek rosszindulatú szövetekben, Ennek kvatitatív jellemzésére korábban az úgynevezett redox arányt (a FAD és NADH fluoreszcencia intenzitás aránya) használták. Mint a 9. ábrán látható, a FLIM képek bővebb információt nyújtanak a sejtek metabolikus állapotáról [63, 66]. Hasonló diagnosztikai eljárást alkalmaznak a szemészetben is, ahol szintén a két kofaktor redox aránya utalhat a cukorbetegségre már korai stádiumban is [67,68]. 

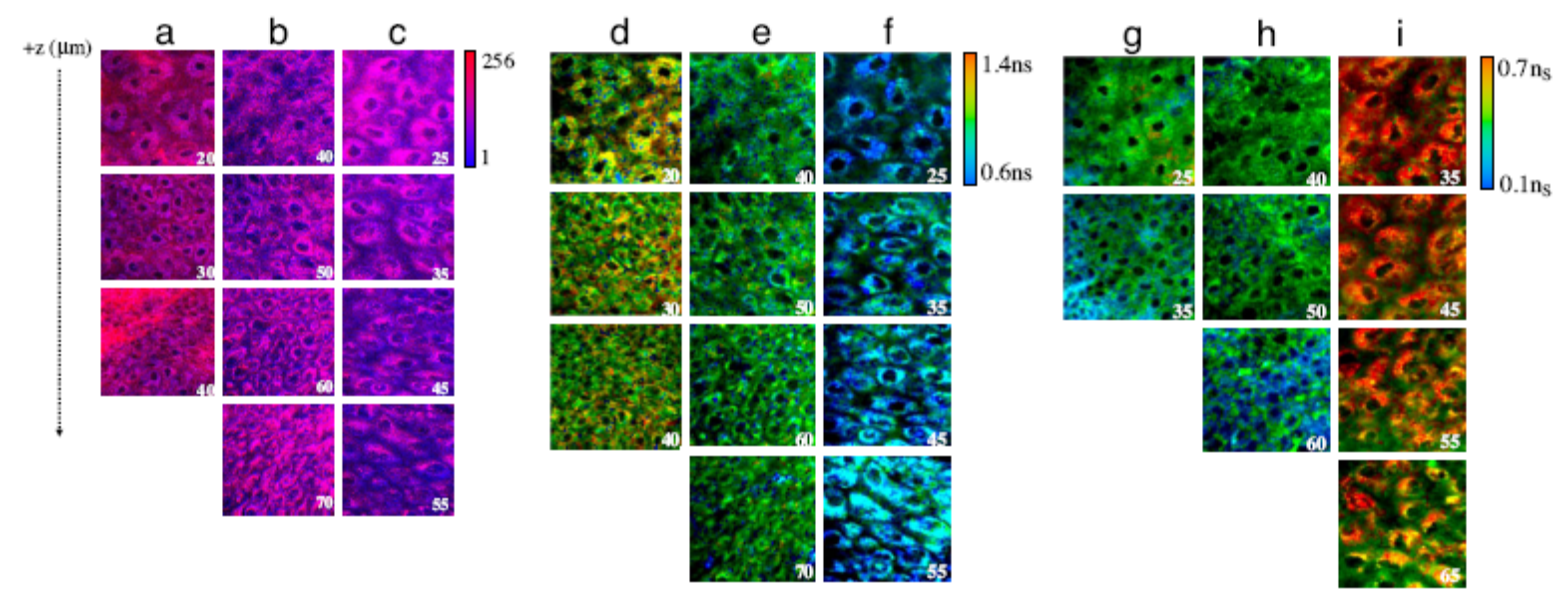

9. ábra - „In vivo” 3 dimenziós többfotonos FLIM felvételek a szövetek diagnosztizálására: (a-c) redox arány; (d-f) átlagos NADH életidő; (g-i) átlagos FAD életidő. Az a,d,g oszlopok normál sejtmüködést, a $b, e, h$ oszlopok rossz sejtműködést, rákos elváltozás korai szakaszát mutatják, amelyet később a $c, f, i$ oszlopok jobb felbontása is megerösít [66].

Összefoglalva tehát a NADH és a FAD fluoreszcencia életidejének mérése lehetőséget biztosíthat a rákos sejtek, illetve egyes neurodegeneratív betegségek, cukorbetegség, öregedés, stb. diagnosztizálására [63, 64, 66-70]. Problémát jelenthet azonban, hogy az „,in vivo" mérések során a túl sok életidő komponens és bonyolultság miatt nehéz egyértelmü korrelációkat találni. Érdemes tehát körbejárni, hogy ezen molekulákon oldat fázisban, az oldószerek polárosságának, H-kötéseinek és $\mathrm{pH}$ értékeinek változtatásával milyen fluoreszcencia jellemzők állapíthatók meg. 


\subsection{A MÉRÉSI MÓDSZEREK ELMÉLETI ALAPJAI}

E fejezetben összefogalalom röviden a munkámhoz szorosan kapcsolódó elméleti spektroszkópiai vonatkozásokat. Bemutatom az általam alkalmazott mérési módszerek alapjait, kitérek az egyes definíciókra. Rövid leírást adok a törésmutatóról, valamint ennek kapcsán az abszorpcióról és diszperzióról, illetve a törésmutató különbségen alapuló integrált optikai szenzorok müködéséről. Összefoglalom az időbontott spektroszkópia alapjait, kitérve részletesebben az általam alkalmazott mérési módszerekre.

\subsubsection{A TÖRÉSMUTATÓ LEÍRÁSA, ÉRTELMEZÉSE}

\subsubsection{A TÖRÉSMUTATÓ}

A fény-anyag kölcsönhatás következtében az anyagot gerjesztő $\tilde{E}(t)=E \cdot e^{(-i \omega t)}$ elektromágneses tér hatására az anyagban $\widetilde{P}(t)$ polarizáció lép fel. A „hagyományos”, azaz lineáris optikában az indukált polarizáció lineárisan függ az elektromos térerősségtől [71], nagy térerősség esetén azonban gyakran E(t)-szerinti sorfejtéssel közelíthető [72], amely mind a lineáris, mind a nemlineáris függést magába foglalja. Homogén, nem mágneses közeg elektromos térre adott válasza végtelen gyors anyagi válasz esetén a következő alakban írható,

$$
\widetilde{\mathrm{P}}(\mathrm{t})=\varepsilon_{0}\left[\chi^{(1)} \widetilde{\mathrm{E}}(\mathrm{t})+\chi^{(2)} \widetilde{\mathrm{E}}^{2}(\mathrm{t})+\chi^{(3)} \widetilde{\mathrm{E}}^{3}(\mathrm{t})+\ldots\right] \equiv \widetilde{\mathrm{P}}^{(1)}(\mathrm{t})+\widetilde{\mathrm{P}}^{(2)}(\mathrm{t})+\widetilde{\mathrm{P}}^{(3)}(\mathrm{t})+\ldots
$$

A $P^{(1)}$ a lineáris polarizációt, a $P^{(2)}, P^{(3)}$ a másod- és harmadrendủ polarizációt jelöli, $\chi^{(1)} \mathrm{a}$ lineáris szuszceptibilitás tenzor, az $\varepsilon_{0}=8,854 \ldots \times 10^{-12} \mathrm{~F} / \mathrm{m}$ pedig a vákuum permittivitása. A $\chi^{(2)}, \chi^{(3)}, \ldots$ tagok sorban a szuszceptibilitás tenzor magasabb rendjeit jelölik. A Maxwellegyenletekből levezethető hullámegyenletben a (2.1)-gyel megadott mennyiség szerepel a forrástagban, amely mind a közeg térre kifejtett hatását, mind a közeg válaszát leírja. A lineáris polarizáció a közeg hagyományos optika keretein belüli válaszát írja le, pl. diszperzió, diffrakció, lineáris abszorpció. A magasabb rendű tagok pedig a nemlineáris optikai jelenségekért felelősek, pl. harmonikus keltés, önfókuszálás, többfotonos abszorpció.

A lineáris polarizáció és a fenomenológikus Maxwell-egyenletekben szereplő elektromos eltolódási vektor kapcsán definiálható a dielektromos tenzor,

$$
\varepsilon=\varepsilon_{r} \varepsilon_{0}=(1+\chi) \varepsilon_{0}
$$


ahol $\varepsilon_{r}$ az anyag relatív permittivitása [71]. Nem mágneses közegekben a hullámegyenlet megoldásaiban fellépő hullámvektor a $\mathrm{k}=\mathrm{n}^{\prime} \omega / \mathrm{c}_{0}$ alakban írható, ha a komplex törésmutatót $\mathrm{n}^{\prime 2} \equiv \mu_{0} \varepsilon \mathrm{c}_{0}{ }^{2}=\varepsilon_{\mathrm{r}}$ módon definiáljuk. Az törésmutató valós része a fázissebességgel, a képzetes rész pedig az abszorpcióval kapcsolatos mennyiség. Mivel a fázissebesség anyagi minőségtől függő mennyiség, az anyagokat egyszerüen a törésmutatójukkal $(n)$ szokás jellemezni, ami a vákuumbeli $\left(\mathrm{c}_{0}\right)$ és anyagbeli fénysebesség aránya $\left(n=c_{0} / c\right)$, másképpen (nem mágneses, átlátszó anyagok esetén):

$$
n=\sqrt{\frac{\varepsilon}{\varepsilon_{0}}}=\sqrt{1+\chi},
$$

tehát az anyagra jellemző első rendű szuszceptibilitás határozza meg. Elektromágneses tér hatására az anyagok elektronszerkezetük (adott $\chi$ ) miatt nem csak bizonyos frekvenciájú fotonokat abszorbeálnak, hanem megváltoztatják a fény terjedési sebességét is, ráadásul a különböző hullámhosszakra nézve különböző mértékben, vagyis diszperziót okoznak. Ezeken túlmenően az anyagi jellemzők határozzák meg a kettőstörés jelenségét is (amelyre a nemlineáris optikai bevezetőben bővebben kitérek). A következőkben nézzük meg kicsit részletesebben az abszorpciót és diszperziót.

\subsubsection{A LORENTZ-FÉLE MODELL, ABSZORPCIÓ ÉS DISZPERZIÓ}

Tekintsünk egy dielektromos közeget, mint rezonáns atomok összességét, amelyben a polarizáció sűrüség $\widetilde{P}(t)$ és az elektromos mező $\tilde{E}(t)$ dinamikus viszonya egy lineáris másodrendü közönséges differenciálegyenlettel leírható. A rezgő oszcillátor $\omega_{0}$ sajátfrekvenciával és $\sigma$ csillapítási együtthatóval (2.1)-ből:

$$
\frac{\mathrm{d}^{2} \widetilde{\mathbf{P}}}{\mathrm{dt}^{2}}+\sigma \frac{\mathrm{d} \widetilde{\mathrm{P}}}{\mathrm{dt}}+\omega_{0}^{2} \cdot \widetilde{\mathrm{P}}=\omega_{0}^{2} \varepsilon_{0} \chi_{0} \widetilde{\mathrm{E}}
$$

ahol

$$
\chi_{0}=\frac{\mathrm{N} \cdot \mathrm{e}^{2}}{\varepsilon_{0} \mathrm{~m} \omega_{0}^{2}} .
$$

Itt $N$ az $m$ tömeggel rendelkező atomok száma egységnyi térfogatban, $e$ pedig az elektron töltése. Ennek a frekvenciafüggő $\chi$-re kiszámolható megoldását az (2.3)-ba behelyettesítve a törésmutató frekvenciafüggése az 


$$
n^{\prime 2}(\omega)=1+\frac{N \cdot e^{2} / \varepsilon_{0} m}{\omega_{0}^{2}-\omega^{2}+i \sigma \omega}
$$

alakban írható le. Ez a Lorentz-féle oszcillátor modell [71].

Az így kapott komplex törésmutató valós része a frekvenciafüggő törésmutatót, azaz a diszperziót, képzetes része pedig az abszorpciót írja le. Vagyis a komplex törésmutató egyszerü alakban

$$
\mathrm{n}^{\prime}=\mathrm{n}+\mathrm{i \kappa}
$$

ahol $n$ a valós törésmutató, $\kappa(\omega)$ pedig az extinkciós koefficiens, amely az abszorpciós koefficiensből, $\alpha(\omega)$-ból származtatható:

$$
\alpha(\omega)=\frac{4 \cdot \pi}{\lambda} \kappa(\omega)
$$

E megközelítésnél a Kramers-Kronig-reláció kimondja, hogy az anyag valós törésmutatója kapcsolatban áll az extinkciós koefficienssel minden egyes frekvencián [71, 73, 74]:

$$
\mathrm{n}(\omega)-1=\frac{\mathrm{c}}{\pi} \mathrm{P} \int_{0}^{\infty} \frac{\kappa\left(\omega^{\prime}\right)}{\omega^{\prime 2}-\omega^{2}} \mathrm{~d} \omega^{\prime}
$$

ahol az integrál előtti $P$ a Cauchy-féle föértéket jelenti.

A diszperzió (azaz a törésmutató hullámhosszfüggése) leírására számos közelítő formula használata terjedt el. Leggyakrabban a Cauchy-, Laurent- és a Sellmeier-típusú formalizmus szerint adják meg egy kérdéses anyag törésmutatóját, persze mindez erősen függ az anyag halmazállapotától és a kérdéses hullámhossztartománytól is (nem részletezve a hőmérséklet, nyomás, stb. hullámhosszfüggését). A Cauchy- és Laurent-formulák a törésmutató-négyzet egyszerü $\lambda^{2}$ szerinti Taylor-sorfejtésén alapulnak [75, 76], hátrányuk viszont, hogy csak szük hullámhossztartományon adnak pontos értéket. A Sellmeier-típusú diszperziós egyenlet azonban a Lorentz-féle oszcillátor modell alapján, az abszorpciós helyektől távoli megoldásokra támaszkodva,

$$
\mathrm{n}(\lambda)^{2}-1=\sum_{\mathrm{i}} \frac{\mathrm{A}_{\mathrm{i}} \cdot \lambda^{2}}{\lambda^{2}-\lambda_{\mathrm{i}}^{2}}
$$

alakban adja meg a diszpeziót, ahol $A_{i}$ és $\lambda_{i}$ a Sellmeier-együtthatók, a hullámhossz pedig $\mu m$ ben van definiálva [77]. E formula már sokkal szélesebb hullámhossztartományra terjed ki, és általánosan alkalmazható például gázokra, folyadékokra, dielektrikumokra, stb.. Munkám során az anyagok törésmutatójának modellezésére a Sellmeier-formulát használtam. 


\subsubsection{IMPULZUSTERJEDÉS DISZPERZÍV KÖZEGBEN}

Méréseimet femtoszekundumos impulzusokkal végeztem. Ebben a fejezetben rövid leírást adok az ultrarövid lézerimpulzusok diszperzív közegben történő terjedéséről, valamint ismertetem a vonatkozó definíciókat.

Az ultrarövid impulzusok közegbeli terjedésének leírását legegyszerübben a Maxwellegyenletekből levezethető hullámegyenlet megoldásaként tárgyalhatjuk, az elektromos térerősség megadásával. A „rövidség” és az ezzel együtt járó nagy sávszélesség miatt az anyagi diszperzió hatása jelentős, amely az impulzus „,szétfolyását” okozza.

Az ultrarövid impulzusok lineáris terjedésének leírásához tekintsünk egy diszperzív közeget, amelyekben a hullámterjedés a frekvenciától függ. Az impulzus terjedését kétféle módon adhatjuk meg: a frekvenciaképben illetve az időképbeli leírással [78]. Az idő- és frekvencia-képbeli leírás között a Fourier-transzformáció teremt kapcsolatot. Mivel méréseimet a frekvenciaképbeli leírás alapján lehet értelmezni, így a következőkben csak erről ĺrok röviden.

A közegbe belépő impulzus időbeli $E_{b e}(t)$ térerősségét előállíthatjuk olyan $\omega$ frekvenciájú monokromatikus komponensek szuperpozíciójával, amelyek $a_{b e}$ amplitudóval és $\phi_{b e}(\omega)$ fázissal írhatók le. Az időbeli térerősség így

$$
E_{b e}(t)=\int_{-\infty}^{+\infty} a_{b e}(\omega) e^{i \phi_{b e}(\omega)} e^{i \omega t} d \omega
$$

alakú. Közegben való terjedés során nemcsak a spektrális komponensek amplitudójának eloszlása változik $A(\omega)$ amplitudó-átvitellel, hanem a fázisuk is eltolódik $\phi(\omega)$-val. A közeget elhagyó impulzus időbeli alakját a spektrális térerősség Fourier-transzformáltja adja. Az így megváltozott fázisú és amplitudójú monokromatikus komponensek összegzésével megkapjuk a közegből kilépő jel időbeli térerősségét:

$$
E_{k i}(t)=\int_{-\infty}^{+\infty} A(\omega) a_{b e}(\omega) e^{i\left(\phi_{b e}(\omega)-\phi(\omega)\right)} e^{i \omega t} d \omega
$$

Az impulzusterjedés illetve a fény-anyag kölcsönhatás következtében bekövetkező időbeli torzulást a közegnek az impulzus fázisszerkezetére gyakorolt hatása okozza. A $\phi(\omega)$ fázisátvitelt jellemezhetjük oly módon, hogy $\phi(\omega)$-t Taylor-sorba fejtjük az $\omega_{0}$ központi frekvencia körül:

$$
\phi(\omega)=\phi\left(\omega_{0}\right)+\phi^{\prime}\left(\omega_{0}\right) \Delta \omega+\frac{1}{2} \phi^{\prime \prime}\left(\omega_{0}\right) \Delta \omega^{2}+\frac{1}{6} \phi^{\prime \prime \prime}\left(\omega_{0}\right) \Delta \omega^{3}+\ldots,
$$


ahol $\Delta \omega=\omega-\omega_{0}$ és

$$
\phi^{\prime}\left(\omega_{0}\right)=\left.\frac{\mathrm{d} \phi}{\mathrm{d} \omega}\right|_{\left(\omega=\omega_{0}\right)} ; \phi^{\prime \prime}\left(\omega_{0}\right)=\left.\frac{\mathrm{d}^{2} \phi}{\mathrm{d} \omega^{2}}\right|_{\left(\omega=\omega_{0}\right)} \ldots
$$

A fenti tárgyalás alapján az impulzusterjedés leírásához szükségünk van a $\phi(\omega)$ ismeretére, amely tulajdonképpen a diszperzió mértékével és minőségével kapcsolatos.

Mivel a legtöbb esetben a terjedés tényleges geometriai hosszát nem ismerjük, ezért az impulzus terjedésének általánosabb leírásához célszerü közvetlenül a $\phi(\omega)$ fázisfüggvényt, és annak deriváltjait használni. A következőkben vegyük végig, hogy milyen fizikai jelentés tulajdonítható az egyes fázisderiváltaknak (10. ábra). A $\phi\left(\omega_{0}\right)$ állandó fázistolást jelent, az $E(t)$ intenzitásburkolón belüli kezdőfázissal kapcsolatos mennyiség (carrier envelope phase, CEP). Ennek csak néhány optikai ciklusból álló impulzusok esetén van jelentősége [79-81].

A $\phi^{\prime}\left(\omega_{0}\right)$ idő dimenziójú mennyiség. Azt mondhatjuk, hogy $\phi^{\prime}\left(\omega_{0}\right)$ az az idő, ami alatt az $\omega_{0}$ központi frekvenciával jellemezhető impulzus a közegen keresztülhalad. Mindezek alapján terjedési időnek, vagy más néven csoportkésleltetésnek (group delay, GD) nevezzük.

A $\phi^{\prime \prime}\left(\omega_{0}\right)$ a csoportkésleltetés-diszperzió (group delay dispersion, GDD), amely az impulzus kiszélesedéséért felelös. A $\phi^{\prime \prime \prime}\left(\omega_{0}\right)$-t pedig harmadrendü diszperziónak (third order dispersion, TOD) nevezzük, mely az időbeli alak megváltozásáért, elö- illetve utóimpulzusok megjelenéséért felelős.

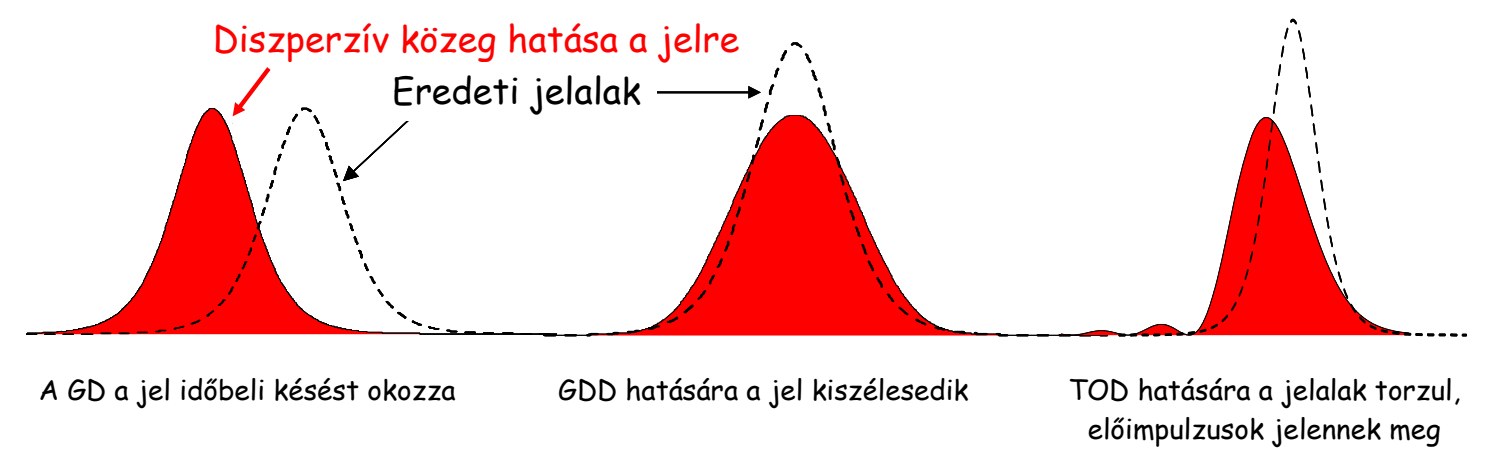

10. ábra - A fázisderiváltak hatásai az impulzusra

A magasabb rendü tagokat pl. fázismodulált impulzuserősítésnél szokták figyelembe venni, azonban a legtöbb esetben elhanyagolható a hatásuk (a páros és páratlan rendek a GDD és TOD-nak megfelelő változásokat okozzák). 
A különböző optikai elemek fázistulajdonságainak jellemzésére a $\phi^{\prime}\left(\omega=\omega_{0}\right)$ és $\phi^{\prime \prime}\left(\omega=\omega_{0}\right)$ fázisderiváltak értékeit szokás megadni, azonban bizonyos esetekben (pl. dielektrikum tükrök) magát a $\phi^{\prime}(\omega)$ ill. $\phi^{\prime \prime}(\omega)$ függvényt használják.

Az időbontott spektroszkópiai alkalmazások során kulcskérdés, hogy a $\mathrm{t}=0$ időpontot pontosan meghatározzuk, ami a pumpa és próba impulzusok tökéletes átfedésének időpontját jelenti (ld. 4. fejezetekben részletesen). Itt minden esetben figyelembe kell vennünk, hogy az optikai elemek és közegek GD és GDD-je az impulzusalakra milyen hatással van. Hiszen a közegben terjedő impulzusban a vivőhullám hullámhossza egyre hosszabb az impulzus végén. Ezt a jelenséget gyakran csörpnek (az angol chirp szó után) is nevezik ${ }^{2}$. A vákuumbeli terjedéshez képest az impulzus lemarad, megnyúlik. Mindezt az idő- és spektrálisan bontott mérések során korrigálnunk kell.

\subsubsection{INTEGRÁLT OPTIKAI SZENZOROK}

A teljesen optikai elven működő fénykapcsolás (all-optical switching) megvalósítására MachZehnder-interferométert (kétsugaras interferométer) vagy integrált optikai sík hullámvezetőt is használhatunk [82]. Ebben az alfejezetben egy rövid áttekintést nyújtok a későbbiekben „Ultragyors optikai kapcsolás bakteriorodopszinnal” c. fejezet - használt sík hullámvezető müködési elvéről, valamint egy ezen az eszközön alapuló, Optical Waveguide Lightmode Spectroscopy (OWLS) elnevezésű mérési módszerről. Ez a technika a 70-es években [83] alakult ki a többi teljes fényvisszaverődésen alapuló, felületi adszorpció mérési eljáráshoz felületi plazmon rezonancia (SPR), teljes reflexiós Fourier-transzformációs infravörös spektroszkópia - hasonlóan [84-87].

A sík hullámvezető egy szubsztrátra (üveg, félvezető, stb.) felvitt vékony, nagy törésmutatójú anyagból készült réteg, amelyben (klasszikus megközelítésben) a fény a teljes visszaverődés útján terjed és a hullámvezető rétegben kialakuló intenzitás-eloszlás a réteg határfelületeiről visszaverődő hullámok interferenciája révén alakul ki (11. ábra). Kimutatható, hogy az elektromágneses tér részben behatol a szomszédos rétegekbe is, ezáltal azok törésmutatója is befolyásolja a vezető rétegben terjedő hullám paramétereit. Emiatt az ún. evaneszcens hullám miatt a vezető rétegbe visszaverődő fény a beesési szögtől, a hullám polarizációjától, ill. a két réteg törésmutatójától függő fázistolást szenved (Goos-Hänchen

\footnotetext{
${ }^{2}$ Más néven csiripelés: mivel a lineárisan változó frekvenciájú, hallható hanghullám a madárfüttyre emlékeztet.
} 
shift), így a hullámvezetés csak bizonyos nagyon éles rezonanciafeltételek mellett jöhet létre [88, 89]. Amennyiben a fent említett interferencia esetén a maximális erősítés feltétele teljesül, a vezető rétegben kialakul az ún. vezetett módus. A módusok rendje megegyezik a vezető réteg keresztmetszete mentén kialakuló intenzitás-eloszlás minimumainak számával. Megmutatható, hogy minden rendü módus csak két-két (a beeső hullám polarizációjától függő), egymástól jól elkülönülő beesési szögek esetén jön létre. Gyakorlati alkalmazásokban a hullámvezetőben terjedő fény paramétereit vizsgálva következtethetünk a vezető réteg felett elhelyezkedő réteg, az ún. adlayer törésmutató-változására.

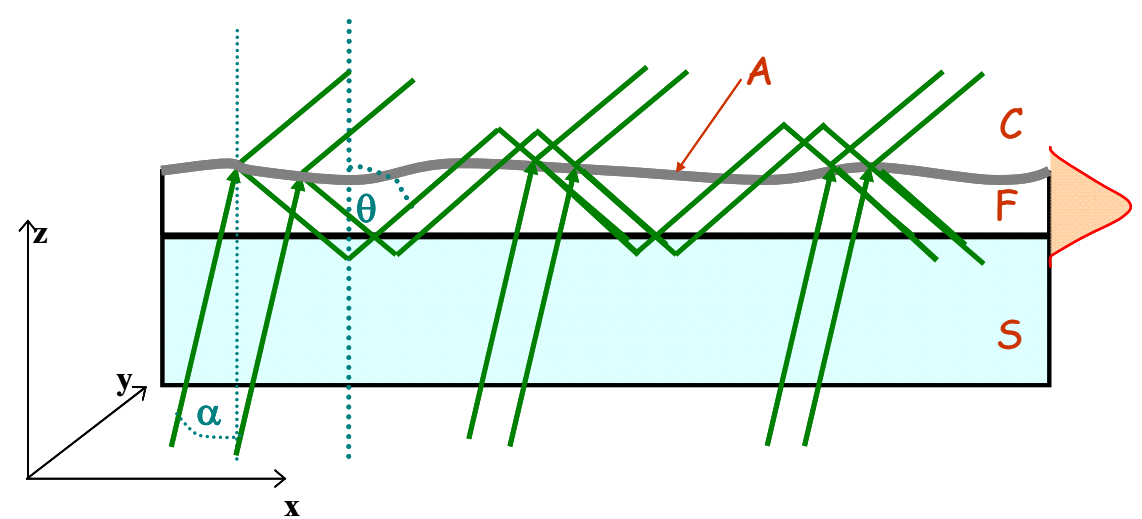

11. ábra - Hullámvezető szemléltetése ${ }^{3}: \mathrm{S}$ : üveghordozó; F: hullámvezető filmréteg;

A: adszorbeálódott anyag; $\mathrm{C}$ : fedőréteg (Az ábra jobb szélén az elektromágneses tér intenzitás eloszlását szemléltetem 0 -ad rendủ módus esetén.)

A rezonanciafeltételek megteremtésére, azaz egy vezetett módus gerjesztésére többféle megoldás létezik. Gerjeszthetünk módusokat a hullámvezető élének különleges kialakításával („tapered coupler”), prizmás csatoló (,prism coupler”), továbbá optikai rács („grating coupler”) alkalmazásával is. Az optikai rács - a prizmához hasonlóan - spektrális bontóelemként is szerepet játszik.

A 11. ábra a rácsos csatolót szemlélteti, amikor a vezető rétegbe, vagy a szubsztrátvezető réteg határfelületére integrált optikai rács által diffraktált fényt csatoljuk a hullámvezetőbe. A sorozatos visszaverődéskor a fény önmagával interferál. Csak abban az esetben történik hullámvezetés, amikor a becsatolt fény önmagával fázisban van, azaz egy

\footnotetext{
${ }^{3}$ A Maxwell-egyenletekből induló hosszas számítások azt az eredményt adják, hogy a hullám a határfelületen, azzal párhuzamosan állandó amplitúdókkal halad, a felületre merőlegesen, a második közegben befelé pedig az amplitúdók exponenciálisan csökkennek (evaneszcens hullám), és a fázisok ugyanazok, mint a felszínen. Bár a második közegben van elektromágneses tér, ennek ellenére kimutatható, hogy a Poynting-vektor normális komponensének időbeli átlaga elhanyagolható, ha a mérési idő nagy a rezgésidőhöz képest. Mivel az elektromágneses tér keltéséhez energiára van szükség, fel kell tételezni, hogy az energia periodikusan oda-vissza áramlik.
} 
„cikk-cakk“ során $2 \pi m(m=0,1, \ldots)$ fázistolást szenved. Az $x$ irányban a fény terjedését a hullámszám vektor $k_{x, F}$ komponense szabja meg, aminek segítségével bevezethetjük a hullámvezetőre jellemző $N$ effektív törésmutató mennyiséget:

$$
\mathrm{N}=\frac{\mathrm{k}_{\mathrm{x}, \mathrm{F}}}{\mathrm{k}}=\mathrm{n}_{\mathrm{F}} \cdot \sin \Theta=\mathrm{n}_{0} \sin \alpha+\frac{1 \lambda}{\Lambda}
$$

ahol $\lambda$ a lézer hullámhossza, $k=2 \pi / \lambda$ a vákuumbeli hullámszám, $n_{0}$ a levegő törésmutatója, $l$ a diffrakció rendje, $\Lambda$ pedig a rácsállandó. Abban az esetben, amikor a törésmutató csak a $z$ irányban változik (step-index waveguide), a Maxwell-egyenleteket megoldva kiszámolhatjuk a fázistolást a transzverzális elektromos (TE) és a transzverzális mágneses (TM) hullámokra [90]. Ennek alapján a háromrétegü hullámvezető módusegyenleteit a következő alakban írhatjuk fel:

$$
\mathrm{d}_{\mathrm{F}} \mathrm{k} \sqrt{\mathrm{n}_{\mathrm{F}}^{2}-\mathrm{N}^{2}}-\arctan \left[\left(\frac{\mathrm{n}_{\mathrm{F}}}{\mathrm{n}_{\mathrm{C}}}\right)^{2 \cdot \rho} \frac{\sqrt{\mathrm{N}^{2}-\mathrm{n}_{\mathrm{C}}^{2}}}{\sqrt{\mathrm{n}_{\mathrm{F}}^{2}-\mathrm{N}^{2}}}\right]-\arctan \left[\left(\frac{\mathrm{n}_{\mathrm{F}}}{\mathrm{n}_{\mathrm{S}}}\right)^{2 \cdot \rho} \frac{\sqrt{\mathrm{N}^{2}-\mathrm{n}_{\mathrm{S}}^{2}}}{\sqrt{\mathrm{n}_{\mathrm{F}}^{2}-\mathrm{N}^{2}}}\right]=\pi \cdot \mathrm{m}
$$

A TE polarizációra $\rho=0$, a TM-re pedig $\rho=1$ vonatkozik. A (2.16) egyenletet $N$-re megoldva kapjuk az adott vezetett módus effektív törésmutatóját, a (2.15) jobb oldala pedig összefüggést teremt $N$ és az optikai rácsra történő $\alpha$ beesési szög között.

A fenti elven alapul az OWLS-technika [91-93], amellyel az adlayer törésmutatójának megváltozását a vezetett módus effektív törésmutatója változásának mérésére vezethetjük vissza. A tisztán optikai elven müködő fénykapcsolásnál használt OWLS paramétereit a „Tudományos eredményeim” c. fejezetben részletezem.

\subsubsection{AZ IDŐBONTOTT SPEKTROSZKÓPIA ALAPJAI}

A molekuláris spektroszkópia területén fellépő legtöbb probléma megoldható a BornOppenheimer-közelítés keretein belül, amely szerint az elektron-, vibrációs és rotációs állapotok egymástól függetlennek tekinthetőek, a köztük levő csatolás elhanyagolható [94]. Így a molekula egészének energiája additív módon tevődik össze az elektron gerjesztési, a rotációs és a különböző forgástengelyek vibrációs energiáiból. Egy másik egyszerüsítést is szokás kihasználni, miszerint a különböző típusú állapotok energetikailag jól elkülöníthetők. Az elektronok átrendeződéséhez például nagy energia szükséges, így ezek az UV-látható spektrális tartományba eső fotonokkal gerjeszthetők. 
A molekulák energiaszint rendszerét, és az ehhez kapcsolódó spektroszkópiai jelenségeket és definíciókat a 12. ábrán bemutatott Jablonski-féle termséma szemlélteti. Alapállapotban a szingulett (ábrán S-sel jelölve) elektronszerkezettel rendelkező molekulák az $\mathrm{S}_{0}$ alapállapotú nívó megfelelő vibrációs és rotációs szintjein vannak. Foton elnyelésekor, vagyis abszorpció következtében az elektroneloszlás a molekulában átrendeződik (fs időtartomány), és a molekula az első $\left(\mathrm{S}_{1}\right)$ vagy magasabb elektrongerjesztési állapotba kerül. Újabb foton elnyelése során az ábrán nem jelzett átmenetek is lehetségesek az egyes gerjesztett állapotok között (excited state absorption, ESA). Mivel a gerjesztett állapotba került molekulák vibrációs szintek közötti eloszlása nem feltétlenül felel meg a környezettel való termikus egyensúlynak, hőcsere történik a környezet és a molekula között. Ezt termikus relaxációnak hívjuk, a folyamatra jellemző időállandó a fs-ps tartományba esik. A gerjesztett állapot nem stabil. A lecsengés - azaz az $\mathrm{S}_{0}$ alapállapotba történő visszatérés - a gerjesztett állapotból több módon is történhet, amely a molekulától és a környezetétől függően különböző valószínűséggel következhet be. Egyik út a sugárzás nélküli átmenet, amely során a gerjesztési energia teljes egészében hővé alakul (belső átalakulás, internal conversion, IC). Másik út a rendszerek közti átmenet (intersystem crossing, ISC), amelynél a gerjesztési energia részben megmarad, részben pedig hővé alakul.

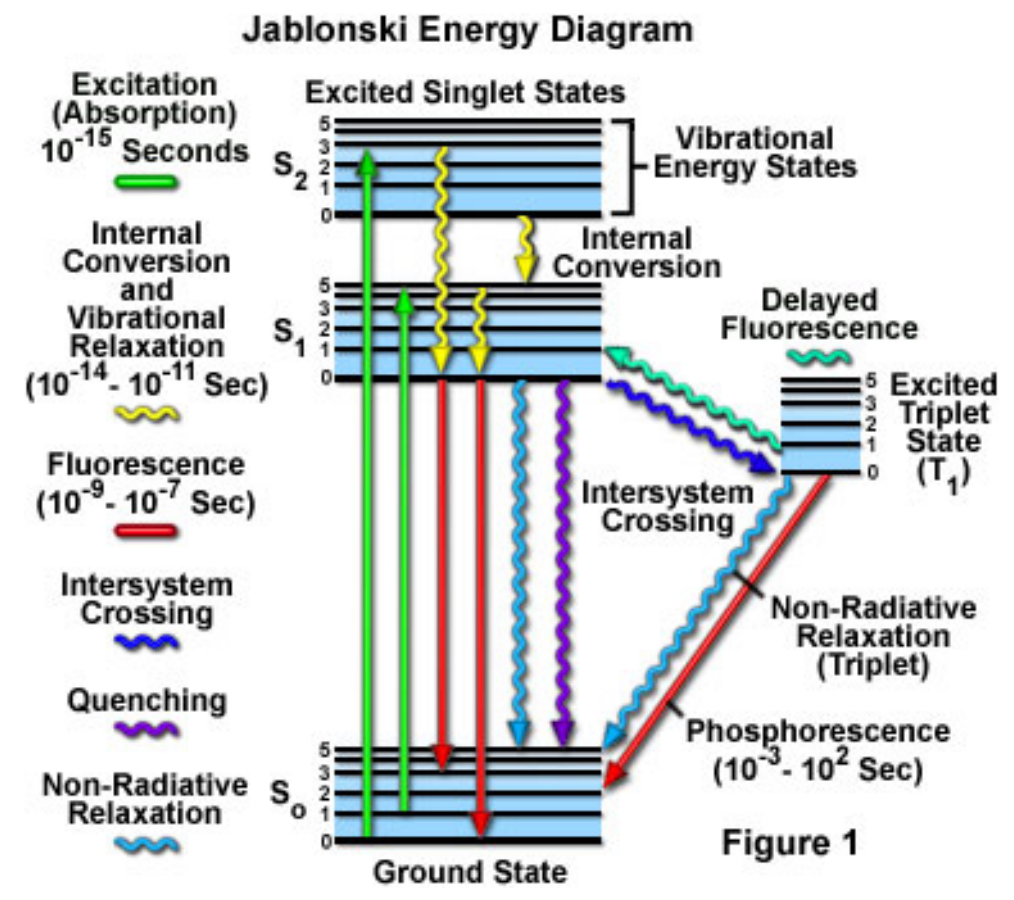

12. ábra - Jablonski-diagram sematikus rajza [95] 
Az energiát átvevő akceptor rendszer a gerjesztett molekula triplett (az ábrán $\mathrm{T}$ betűvel jelölve) állapota. A harmadik lehetőség a fénykibocsátás, amelyet fluoreszcenciának (F) vagy foszforeszcenciának hívunk, attól függően, hogy a molekula szingulett vagy triplett állapotából történik a sugárzásos átmenet az alapállapotba. A kettőt spektrumuk és időbeli lecsengésük alapján könnyen el lehet különíteni egymástól. A 12. ábrán jól látható, hogy a foszforeszcencia fotonenergiája kisebb, mint a fluoreszcenciáé, így spektruma a hosszú hullámhosszak felé tolódik. Másrészről a foszforeszcencia - a triplett állapotból a szingulett állapotba történő átmenet - tiltott, mert a spin átfordulásával jár együtt, s emiatt élettartama 5-7 nagyságrenddel nagyobb, mint a fluoreszcenciára jellemző $10^{-12}-10^{-7} \mathrm{~s}$.

\subsubsection{FLUORESZCENCIA SPEKTROSZKÓPIAI ALAPOK}

A fentiekben tárgyalt termikus relaxáció következtében a fluoreszcenciához tartozó energiaátmenet mindig kisebb, mint az abszorpcióhoz tartozó. A két spektrum csúcsa közti eltolódást Stokes-eltolódásnak (Stokes shift) hívjuk [96]. A Stokes-eltolódás a környezeti feltételektől, valamint a gerjesztett állapot geometriai változásaitól függ. NADH és FAD koenzimek esetében a Stokes-eltolódás 120 illetve $90 \mathrm{~nm}$ (7. és 9. ábra). (Ugyanakkor nanorészecskék illetve kvantumdotok esetében például az eltolódás csak 10-20 nm.)

A fluoreszkáló anyagot nem csak abszorpciós és emissziós spektrumával szokás jellemezni. Jellemző paraméterei még a sugárzás kvantumhatásfoka és a gerjesztett állapot élettartama. A fluoreszcencia tipikusan exponenciális lecsengést követ:

$$
\mathrm{I}(\mathrm{t})=\mathrm{I}_{0} \cdot \mathrm{e}^{-\mathrm{kt}}
$$

ahol $I(t)$ a fluoreszcencia intenzitásának időbeli változása, $I_{0}$ a kezdeti intenzitás $\mathrm{t}=0$ időpontban, a $k$ pedig a bomlási sebességi állandó (a fluoreszcencia életidő inverze). Az $I(t)$ arányos az elektron populációval az $\mathrm{S}_{1}$ állapotban. Mivel a gerjesztett állapot többféle módon (IC, ISC, F) kiürülhet, a teljes bomlási sebességi állandó $\left(\mathrm{k}_{T O T}\right)$ a sugárzásos $(\mathrm{rad})$ és a nem sugárzásos ( $\mathrm{nrad})$ átmenetek összegéből adódik:

$$
\mathrm{k}_{\mathrm{TOT}}=\sum_{\mathrm{i}} \mathrm{k}_{\mathrm{i}}=\mathrm{k}_{\mathrm{rad}}+\mathrm{k}_{\mathrm{nrad}}^{\mathrm{i}}=\frac{1}{\tau} \text {. }
$$

Tehát amennyiben bármelyik sebességi állandó nagy, az élettartam $(\tau)$ nagyon rövid lesz, és fordítva. Az egyes $\mathrm{k}_{\text {nrad }}^{\mathrm{i}}$ értékek függhetnek a szerkezeti inhomogenitástól, ami többszörös fluoreszcencia életidők megjelenéséhez vezet. 
A fluoreszcencia folyamat hatékonyságát a kvantumhatásfokával ( $\eta)$ szokás jellemezni. Definíció szerint ez a kibocsátott és elnyelt fotonok számának aránya [96], amely a (2.17) és (2.18) egyenletek alapján a következő egyszerű alakban is felírható:

$$
\eta=\frac{\mathrm{k}_{\mathrm{rad}}}{\mathrm{k}_{\mathrm{TOT}}}
$$

A fluoreszcenciára képes molekulák vagy fluorofórok kvantumhatásfoka széles körben változhat. Néhány festéknél megközelítheti vagy elérheti az 1 értéket (100\%), vagyis minden egyes elnyelt foton kisugárzódik. Ez esetben az alapállapotba történö lecsengés tisztán a fluoreszcenciából adódik.

Számos folyamat növelheti a nem sugárzásos átmenet valószínűségét, így csökkentheti a fluoreszcencia intenzitást. Ezeket összefoglaló néven kioltásnak (quenching) szokás nevezni [96], melyek közül a leggyakoriabbak:

- Ütközéses vagy dinamikus kioltás

- Statikus kioltás

- Energia átadás révén történő kioltás

- Gerjesztett állapotban töltés átviteli reakciók

- Izomerizáció

A biokémiai alkalmazásokban a kioltás tényéből szerkezeti információkra következtethetünk [96]. Egyes kioltó anyagok (pl. oxigén, jodid, stb.) jelenléte a fluorofór közelében a fluoreszcencia csökkenése alapján könnyen kimutatható, a kioltás mérése például a kötőhelynek a kioltó számára való hozzáférhetőségéről ad felvilágosítást. A fluoreszcencia (egy másik, akceptormolekulához irányuló) FRET miatti csökkenése pedig biomolekulák asszociációs reakcióinak, konformációs változásainak vizsgálatára alkalmas. A fluoreszcencia élettartama érzékeny indikátora a molekula belső szerkezetének és a környezettel való kölcsönhatásainak. Mindezért érdemes tehát időben is és spektrálisan is nyomon követni a fluoreszcencia változását.

\subsubsection{IDŐBONTOTT FLUORESZCENCIA SPEKTROSZKÓPIA MÉRÉSI MÓDSZEREI}

\section{A PIKOSZEKUNDUM FELETTI IDÖTARTOMÁNY}

A pikoszekundumos-nanoszekundumos időtartományban több fluoreszcencia mérési módszer terjedt el, ilyenek a fázismoduláción, a Streak-kamerán vagy az idökorrelált egy-foton számláláson (time correlated single photon counting, TCSPC) alapuló módszerek [96-98]. 
A fázismodulációs technika lényege abban áll [96], hogy szinuszosan modulált gerjesztő fény esetén a fluoreszencia is szinuszos lesz. A szinuszok közötti fáziskülönbséget mérve számolható a fluoreszcencia lecsengési ideje. E módszer időfelbontása 100 ps körüli. Nagy hátránya viszont, hogy nagyon bonyolultan alkalmazható összetett kinetikák esetén, ami miatt a biológiai anyagok vizsgálatánál nem igazán alkalmazható.

A Streak-kamerán alapuló módszer [96] egylövéses technika, melynek nagy előnye, hogy spektrográffal kombinálva közvetlen szolgáltatja a mérendő adatokat. Felbontása akár $\sim 1$ ps alatti is lehet (Hamamatsu C6138 (FESCA-200) 200 fs!). A Streak-kamera egy olyan katódsugárcső, melyben a beérkező fényimpulzus által kiváltott fotoelektronokat térítenek el gyorsan változó elektromos tér segítségével. Ezáltal az ernyőn becsapódó elektronok térbeli eloszlása arányos lesz az impulzus időbeli eloszlásával [99]. Egyes Streak-kamerák nem csak időbontott, hanem hullámhosszbontott mérésekre is alkalmasak. Hátrányuk viszont, hogy a jel/zaj arány és a felbontás között kompromisszumot kell kötnünk, s nem elhanyagolható a magas ára sem.

Jó kompromisszumot jelent azonban a TCSPC technika, amely időfelbontása akár 25 ps is lehet (pl. Hamamatsu R3809). Ára jóval a Streak-kamera ára alatt van, és mivel a „fotononkénti számláláson” alapul, így igen érzékeny technika. Müködésének lényege (13.a ábra), hogy egy a gerjesztő impulzusból származó start jellel elindítunk egy idő-amplitúdó konvertert (TAC), amelyet a fluoreszcenciából származó első foton detektálásakor leállítunk. Ezáltal megkapjuk a két esemény közötti időkülönbséget. (A gyakorlatban célszerübb a fordított eljárás, vagyis a start jel származik a fluoreszcenciából és egy késleltető kábelen áthaladt stop jel pedig a gerjesztő impulzustól.)
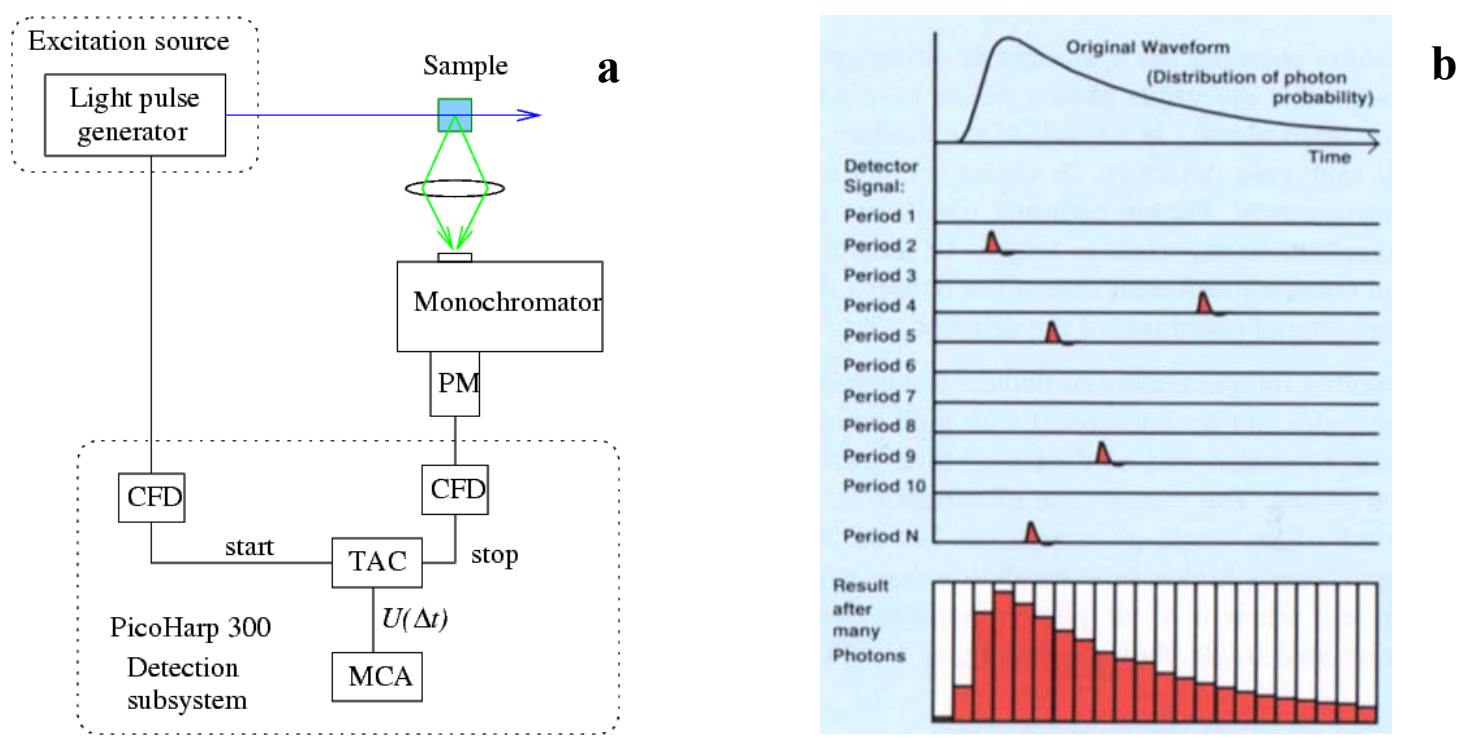

13. ábra - (a) A TCSPC technika kísérleti elrendezése és (b) a TCSPC módszer alapja [100] 
Ha ezt az eljárást kellően sokszor megismételjük, egy hisztogrammot kapunk, ami a beérkezett fotonok idejét, vagyis a fluoreszcencia lecsengését rajzolja ki, amelyet a $13 . b$ ábrán láthatunk. E módszer időfelbontása a detektor típusától függ. Az aránylag olcsó lavina dióda alkalmazásával $\sim 40$ ps időfelbontás érhető el. Az időablakunk hosszát a lézerünk ismétlési frekvenciája szabja meg. Ez titán-zafír oszcillátorok alkalmazása - tipikusan $70-80 \mathrm{MHz}$ körüli ismétlési frekvencia - esetén $\sim 13$ nanoszekundumot jelent.

\section{A FEMTOSZEKUNDUMOS TARTOMÁNY - NEMLINEÁRIS OPTIKAI ALAPOK}

Míg a pikoszekundum feletti időtartományban több fluoreszcencia mérési módszer terjedt el (ld. előző alfejezet), addig a femtoszekundumos tartományban csak önreferenciás eljárások alkalmazhatóak. A femtoszekundumos időfelbontású spektroszkópia minden területén alkalmazott önreferenciás módszerek közös vonása, hogy az időmérést a fénysebesség ismeretében távolságmérésre vezethetjük vissza. Ennek megfelelően a femtoszekundumos fényforrásból származó nyalábot kettéosztjuk. Az egyik nyaláb a minta gerjesztését végzi. A másik nyaláb először egy ismert hosszúságú késleltető vonalon halad át. Ezután vagy a mintán halad keresztül megmérve annak valamely optikai tulajdonságát (mint a későbbiekben ismertetett abszorpció kinetikai pumpa-próba mérések esetében), vagy a mintából a gerjesztés következtében kilépő fénnyel lép kölcsönhatásba egy nemlineáris optikai folyamat során. Mindkét esetben intenzitás értékeket mérünk, melynek időbeli függése a késleltető vonal hosszának ismételt megváltoztatása segítségével rekonstruálható. A fluoreszcencia életidő mérések esetében az egyik lehetséges önreferenciás módszer az ún. Kerr-kapuzás [101, 102], a másik pedig a frekvencia konverzió $[96,103,104]$.

A Kerr-effektuson alapuló optikai kapuzás- a módusszinkronizált lézerek megjelenésével - már az 1970-es évek második felében elterjedt [101]. A Kerr-elrendezésben a fluoreszcencia fény áthalad két keresztpolarizátoron, amelyek között izotróp Kerr-közeg (rendszerint egy üveglap) van elhelyezve. A kísérleti elrendezés zárt állapotban a fluoreszcens fényt nem engedi át. A Kerr-közegbe fókuszált kapuzó impulzus által „optikai nyitás” (önfókuszálás ill. önfázismoduláció) történik, mert az intenzitás olyan nagy, hogy az üveglap törésmutatóját megváltoztatja, melynek következtében optikai anizotrópia indukálódik/keletkezik. Ez megváltoztatja a fluoreszcencia fény polarizációs állapotát (lineárisból elliptikusra), így a fény már áthalad a második polarizátoron, és ezáltal detektálhatóvá válik [102]. Előnye, hogy ennél a módszernél nem kell fázisillesztést 
alkalmazni, tehát a teljes spektrum egyszerre detektálható. Csak a detektor érzékenysége és az optikai elemek áteresztő képessége limitálja. Hátránya viszont, hogy a nemlineáris törésmutatón alapuló folyamat harmadrendü folyamat, nagy intenzitásokat követel méréstechnikailag, vagyis erősített lézerrendszer szükséges hozzá.

Méréseim során a frekvencia átalakításon alapuló önreferenciás módszert használtam, melyet „fluorescence up- and/or down-conversion method” névvel illet a szakirodalom [96, 103, 104]. Én fluoreszcencia fel- és le-konverziónak, vagy egyszerüen csak fluoreszcencia frekvencia átalakításnak hívom a későbbiekben. A 14. ábra a frekvencia konverzión alapuló mérési módszert szemlélteti. Lényege abban áll, hogy a kettéosztott lézerimpulzus egyik felével (pumpa) a vizsgálandó anyagon fluoreszcenciát gerjesztünk, a másik (kapuzó, gate) nyaláb pedig késleltető vonalon halad keresztül. Ezután a kapuzó, $\omega_{1}$ frekvenciájú impulzussal és a fluoreszcencia fény egy $\omega_{2}$ frekvenciájú komponensével összeg- vagy különbségi frekvenciát keltük egy nemlineáris kristályban. A keltett, új frekvenciakomponens így mintavételezi a fluoreszcencia fény intenzitását a késleltetésnek megfelelő időpillanatban. Amennyiben a kapuzó impulzussal időben végigpásztázzuk a folyamatot, megkapjuk a fluoreszcencia lecsengés kinetikáját.

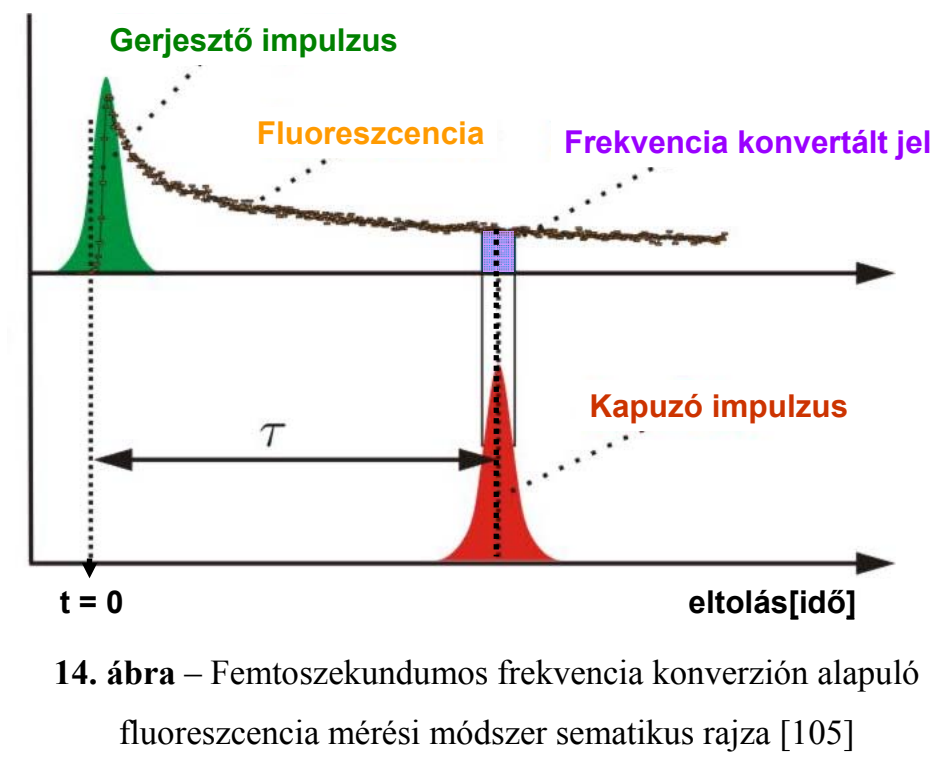

A frekvencia konverzió ez esetben egy másodrendű folyamat, megfelelő $\chi^{(2)}$-vel rendelkező anyagot választva [106] a kristályban fellépő másodrendü polarizáció leírható (2.1) segítségével, ha azt a két különböző, $\omega_{1}$ és $\omega_{2}$ frekvenciákra alkalmazzuk: 


$$
\begin{aligned}
& \tilde{\mathrm{P}}^{(2)}(\mathrm{t})=\varepsilon_{0} \cdot \chi^{(2)} \cdot \tilde{\mathrm{E}}(\mathrm{t})^{2}= \\
& =\varepsilon_{0} \cdot \chi^{(2)} \cdot\left[\mathrm{E}_{1}^{2} \cdot \mathrm{e}^{-2 i \omega_{1} \mathrm{t}}+\mathrm{E}_{2}^{2} \cdot \mathrm{e}^{-2 \mathrm{i} \omega_{2} \mathrm{t}}+2 \mathrm{E}_{1} \mathrm{E}_{2} \cdot \mathrm{e}^{-\mathrm{i}\left(\omega_{1}+\omega_{2}\right) \mathrm{t}}+2 \mathrm{E}_{1} \mathrm{E}_{2}^{*} \cdot \mathrm{e}^{-\mathrm{i}\left(\omega_{1}-\omega_{2}\right) \mathrm{t}}\right]+ \\
& +2 \cdot \varepsilon_{0} \cdot \chi^{(2)}\left[\mathrm{E}_{1} \cdot \mathrm{E}_{1}^{*}+\mathrm{E}_{2} \cdot \mathrm{E}_{2}^{*}\right]
\end{aligned}
$$

ahol

$$
\tilde{E}(t)=E_{1} \cdot e^{-i \omega_{1} t}+E_{2} \cdot e^{-i \omega_{2} t} .
$$

Tehát a kapuzó impulzus és a fluoreszcencia szuperpozíciója. Megfelelő fázisillesztéssel (lásd alább) elöállítható

- a másodharmonikusa az egyik, $P\left(2 \omega_{1}\right)$ illetve a másik, $P\left(2 \omega_{2}\right)$ frekvenciakomponensnek; a (2.20) egyenlet első és második tagja;

- az összeg- és különbségi frekvenciájuk $\left(P\left(\omega_{1}+\omega_{2}\right)\right.$ és $P\left(\omega_{1}-\omega_{2}\right)$; (2.20)-nek harmadik és negyedik tagja

- valamint az időben állandó DC tag (optical rectification) $P(0)$.

A gyakorlatban azonban ez a fázisillesztési feltétel csak ezen opciók egyikére teljesül.

Munkám során összegfrekvenciát keltettem (sum-frequency generation, SFG) $\mathrm{B}_{-} \mathrm{BaB}_{2} \mathrm{O}_{4}$ (BBO) egytengelyü nemlineáris kristályban, így a későbbiekben csak ennek alapjaira térnék ki egy kicsit részletesebben. A geometriai elrendezést és az energia-szinteket a 15. ábrán szemléltetem.

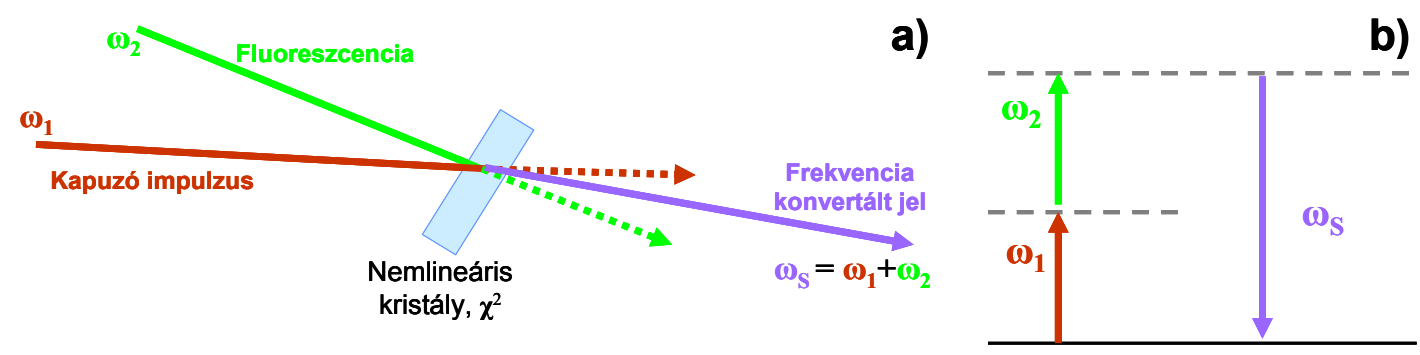

15. ábra - Összegfrekvencia keltés szemléltetése (a) és energiaszintek értelmezése (b)

Az összegfrekvencia keltése parametrikus folyamat (azaz a folyamat csakis a törésmutató valós részétől függ), amelyben az energia a nemlineáris közeg hatására $\left(\chi^{(2)}\right)$ az oszcilláló módusok között a csatolás miatt átcsoportosul. Az energiaáramlás iránya egy adott folyamatban a terek egymáshoz viszonyított relatív fázisától és kezdeti intenzitásától függ. A keltett új komponens intenzitása [72]: 


$$
\mathrm{I}_{\mathrm{S}} \approx \mathrm{d}_{\mathrm{eff}}^{2} \cdot \mathrm{I}_{1} \cdot \mathrm{I}_{2} \cdot \mathrm{L}^{2} \cdot \operatorname{sinc}^{2}\left[\frac{\Delta \mathrm{kL}}{2}\right],
$$

ahol $I_{1}$ és $I_{2}$ a kapuzó impulzus és a fluoreszcencia intenzitásai, $d_{\text {eff }}$ a másodrendü szuszceptibilitás tenzorból számolható, anyagra jellemző paraméter, $L$ pedig a kristály hossza. Jól látszik, a konvertált jel intenzitása $\operatorname{sinc}^{2}$ függvényen keresztül függ a $\Delta \overrightarrow{\mathrm{k}}=\overrightarrow{\mathrm{k}}_{1}+\overrightarrow{\mathrm{k}}_{2}-\overrightarrow{\mathrm{k}}_{\mathrm{s}}$ fázisillesztési paramétertől, ahol $\overrightarrow{\mathrm{k}}_{1}, \overrightarrow{\mathrm{k}}_{2}$ és $\overrightarrow{\mathrm{k}}_{\mathrm{s}}$ az egyes nyalábokhoz tartozó hullámvektorokat jelöli. Maga a frekvenciakeltés a kristályban lokális, a keltett frekvenciakomponens a keltő nyalábbal együtt terjed az elemi komponensek szuperpozíciójának megfelelően. Ha a keltő és keltett komponensek terjedési sebessége különböző - márpedig a diszperzió miatt a három különböző frekvenciájú hullám sebessége nincs illesztve, vagyis $\Delta \overrightarrow{\mathrm{k}} \neq 0 \quad-$, akkor a kölcsönható terek nincsenek egymással fázisban. A kimenő jel erőssége oszcillálni fog a periódikusan konstruktív és destruktív interferencia miatt, ahogyan a kristály hosszán keresztül haladnak. A legjobb konverziós hatásfok elérése érdekében tehát az impulzusmomentumnak is meg kell maradnia, vagyis a $\overrightarrow{\mathrm{k}}$ hullámvektorokra teljesül a $\sum \overrightarrow{\mathrm{k}}_{\mathrm{i}}=0$ feltétel, ami mind a kollineáris, mind pedig a nem-kollineáris fázisillesztés esetét magába foglalja.

A fázisillesztés megvalósításának legelterjedtebb módja az optikai kettőstörő kristályok alkalmazása. Mivel a kettőstörő kristályok törésmutatója különböző a beeső nyaláb polarizácójának függvényében, a beeső nyaláb polarizációjának megválasztásával és a kristály megfelelő forgatásával biztosítható a fázisillesztés a beeső és a keltett hullámok között. Minthogy a törésmutató függ a hullámhossztól, különböző hullámhosszakon a fázisillesztés más-más irányokban teljesül. Az ordinárius $\left(n_{o}\right)$ és extraordinárius $\left(n_{e}\right)$ törésmutatók egymáshoz való viszonyát negatív $\left(n_{e}<n_{o}\right)$ egytengelyü kristályokban - mint pl. BBO, $\mathrm{KH}_{2} \mathrm{PO}_{4}$ vagy az $\mathrm{LiNbO}_{3}$ kristályok -, az indexellipszoiddal szemlélteti (16. ábra). A fázisillesztés irányát az ordinárius polarizációjú $\omega_{1}$ és az extarordinárius polarizációjú $\omega_{2}$ hullám között a $\overrightarrow{\mathrm{k}}$ vektor határozza meg. Ez alapján megkülönböztetünk kollineáris és nemkollineáris elrendezést. 


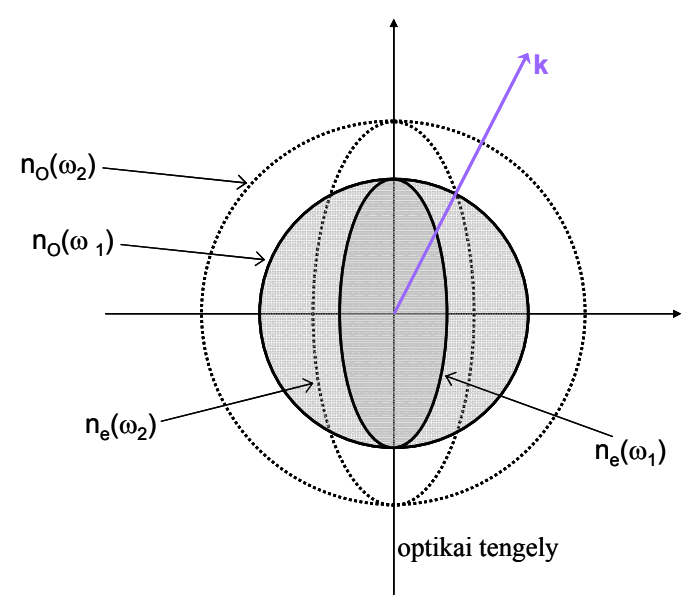

16. ábra - Az indexellipszoid metszete $\mathrm{BBO}$ kritályban

Általában a keltő $\left(\omega_{1}\right.$ és $\left.\omega_{2}\right)$ és a keltett $\left(\omega_{3}\right)$ hullámok polarizációja alapján szokás különbséget tenni a különböző típusú fázisillesztések között:

- I. típusú fázisillesztés: $\mathrm{E}_{\mathrm{o}}\left(\omega_{1}\right)+\mathrm{E}_{\mathrm{o}}\left(\omega_{2}\right)=\mathrm{E}_{\mathrm{e}}\left(\omega_{3}\right)$

- II. típusú fázisillesztés: $\mathrm{E}_{\mathrm{o}}\left(\omega_{1}\right)+\mathrm{E}_{\mathrm{e}}\left(\omega_{2}\right)=\mathrm{E}_{\mathrm{e}}\left(\omega_{3}\right)$

ahol E az elektromos mezőt jelöli extraordinárius hullám (e), valamint ordinárius hullám (o) esetében, továbbá a (2.20) alapján fennáll, hogy $\omega_{1}+\omega_{2}=\omega_{3}$. Mindezt összefoglalva a különböző típusú egytengelyü kristályok esetén az 1. táblázatban mutatom be.

\begin{tabular}{|c|c|c|}
\hline FÁZISILLESZTÉS & $\begin{array}{l}\text { Pozitív EGYTENGELYÜ } \\
\qquad \mathrm{n}_{\mathrm{e}}>\mathrm{n}_{\mathrm{o}}\end{array}$ & $\begin{array}{l}\text { NEGATíV EGYTENGELYÜ } \\
\qquad \mathrm{n}_{\mathrm{e}}<\mathrm{n}_{\mathrm{o}}\end{array}$ \\
\hline I. típusú & $\mathrm{n}_{3}^{\mathrm{o}} \omega_{3}=\mathrm{n}_{1}^{\mathrm{e}} \omega_{1}+\mathrm{n}_{2}^{\mathrm{e}} \omega_{2}$ & $\mathrm{n}_{3}^{\mathrm{e}} \omega_{3}=\mathrm{n}_{1}^{\mathrm{o}} \omega_{1}+\mathrm{n}_{2}^{\mathrm{o}} \omega_{2}$ \\
\hline II. típusú & $\mathrm{n}_{3}^{\mathrm{o}} \omega_{3}=\mathrm{n}_{1}^{\mathrm{o}} \omega_{1}+\mathrm{n}_{2}^{\mathrm{e}} \omega_{2}$ & $\mathrm{n}_{3}^{\mathrm{e}} \omega_{3}=\mathrm{n}_{1}^{\mathrm{e}} \omega_{1}+\mathrm{n}_{2}^{\mathrm{o}} \omega_{2}$ \\
\hline
\end{tabular}

1. táblázat - Az I-es és II-es fázisillesztés megvalósulása különböző típusú kristályok esetén

Munkám során I. típusú fázisillesztést használtam, ahol a BBO kristály fázisillesztési szögét ( $\theta)$ az ordinárius és extraordinárius törésmutatókból meghatározhatjuk például másodharmonikusra:

$$
\sin ^{2} \theta=\frac{\frac{1}{n_{0}^{2}(\omega)}-\frac{1}{n_{o}^{2}(2 \omega)}}{\frac{1}{n_{e}^{2}(2 \omega)}-\frac{1}{n_{o}^{2}(2 \omega)}}
$$


Konkrétan 800 nm központi hullámhosszú impulzusnál másodharmonikus keltés esetén a fázisillesztés szöge 29.5 fok BBO kristályban.

\subsubsection{ABSZORPCIÓS SPEKTROSZKÓPIA ALAPOK}

Egy minta hullámhosszfüggő abszorbanciája (A) vagy optikai denzitása (OD) az

$$
A(\lambda)=-\log _{10} \frac{I(\lambda)}{I_{0}(\lambda)}
$$

kifejezéssel definiált, ahol $I_{0}$ a beeső intenzitás, $I$ pedig a mintán átmenő transzmittált intenzitás. Alapvetően, a statikus abszorpciós spektrum az UV-látható tartományon a mintánk elektron-állapotáról ad információt. Vagyis a termikus egyensúlyi állapotból való energia átmenet különbségét mérjük: az alapállapot $\left(\mathrm{S}_{0}\right)$ és a gerjesztett állapotok $\left(\mathrm{S}_{\mathrm{n}}\right)$ közti különbséget. Emellett a detektált átmenet oszcillátor erősségéről is információhoz juthatunk.

A koncentráció $(C,[\mathrm{M}$ vagy $\mathrm{mol} / \mathrm{l}])$ és a hullámhossz-függő moláris extinkciós együttható $\left(\varepsilon(\lambda),\left[\mathrm{M}^{-1} \cdot \mathrm{cm}^{-1}\right]\right)$ kapcsolata az abszorbanciával a Beer-Lambert-törvény szerint [96]:

$$
\mathrm{A}(\lambda)=\varepsilon(\lambda) \cdot \mathrm{C} \cdot \mathrm{L}
$$

ahol $L$ a vizsgált minta vastagsága $\mathrm{cm}$-ben.

A kémiai kötések szakadása, alakja és változásai a térben ultragyors sebességgel történnek, vagyis a pikoszekundum alatti időtartományban zajlanak. Ezek a dinamikus folyamatok magukba foglalják az elektronok és atommagok mozgását. Ezen folyamatok megfigyeléséhez nem csak széles spektrális tartományra van szükség, hanem femtoszekundumos időfelbontásra is. E témakörrel részletesen a femtokémia illetve a femtobiológia foglalkozik, többek között Ahmed H. Zewail (kémiai Nobel-díj 1999-ben) úttörő munkásságának köszönhetően [17-19]. Ö olyan, ún. pumpa-próba mérési eljárást fejlesztett ki, amellyel femtoszekundumos időskálán követhető a kémiai-biológiai reakciók időbeli lefolyása, azaz a kémiai kötések kialakulásának, bomlásának és átrendeződésének dinamikája atomi szinten.

Tranziens abszorpciós mérésekből többek között az alábbi információkhoz juthatunk:

- Félvezető lézeranyagokban lezajló optikai erősítés mechanizmusa;

- Fotokémiai reakciók kinetikája és dinamikája;

- Intra- és intermolekuláris gerjesztési energiatranszfer. 


\subsubsection{AZ ULTRAGYORS TRANZIENS ABSZORPCIÓ MÉRÉSE}

A tranziens abszorpciós pumpa-próba módszer alapelve könnyen megérthető az alábbi, 17. ábra segítségével. A gerjesztő pumpa impulzust követően, a mintát meghatározott $\mathrm{t}$ időpontokban (az egyik nyaláb késleltetésével) próbaimpulzusokkal világítjuk meg, és detektáljuk a minta abszorpciós spektrumának időbeli változását spektrográf és CCD kamera segítségével. Az időbeli felbontást a pumpa és próba impulzusok konvolúciója adja meg.

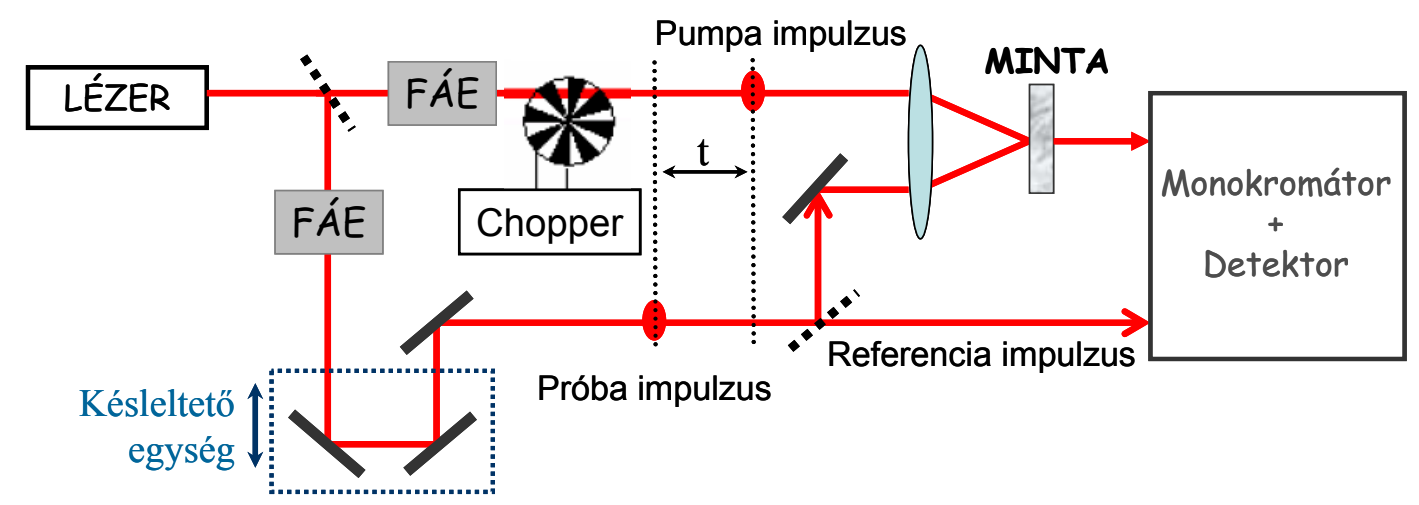

17. ábra - Tranziens abszorpciómérés sematikus rajza (az „FÁE” rövidítés: frekvencia átalakító egység)

Abszorpciós spektroszkópiában az adatok értelmezése az oldott anyag abszorpciójának koncentráció-függésén alapul. Ezt a kapcsolatot a Beer-Lambert-törvény alapján (2.25) felírhatjuk a mintán átmenő, transzmittált intenzitásra $(\mathrm{T})$ :

$$
\mathrm{T}=\frac{\mathrm{I}(\mathrm{t})}{\mathrm{I}(0)}=10^{-\varepsilon(\lambda) \cdot \mathrm{L} \cdot \mathrm{C}}
$$

A detektált jelek analízise tulajdonképpen abban áll, hogy összevetjük a próba intenzitását a mintán való áthaladás után gerjesztéssel illetve gerjesztés hatása nélkül. Ezt a gyakorlatban chopper alkalmazásával szokás megvalósítani, ami periodikusan blokkolja a pumpa nyalábot (ld. 17. ábra). A detektorunkkal így mérjük a próba impulzus intenzitását az alapállapotban gerjesztés nélkül ( $\left.\mathrm{P}_{\mathrm{OFF}}\right)$, és a gerjesztett állapotban a pumpát követően $\mathrm{P}_{\mathrm{ON}}$. A (2.26) alapján a pumpa által indukált abszorpció változása:

$$
\Delta \mathrm{A}(\lambda, \mathrm{t})=\mathrm{A}(\lambda, \mathrm{t})_{\mathrm{P}_{\mathrm{ON}}}-\mathrm{A}(\lambda, \mathrm{t})_{\mathrm{P}_{\mathrm{OFF}}}=-\log \frac{\mathrm{I}(\lambda, \mathrm{t})_{\mathrm{P}_{\mathrm{ON}}}}{\mathrm{I}(\lambda)_{\mathrm{P}_{\mathrm{OFF}}}}
$$


Amikor a próba impulzus nem elég stabil a mérések hosszú ideje alatt, referencia nyalábot szokás használni, ami ugyan nem halad keresztül a mintán, de a próbaimpulzussal egyidejüleg detektálható. Kísérleteim során a próba impulzust két részre osztottam a minta előtt, ahogy azt a 17. ábrán is szemléltettem.

A Beer-Lambert-törvényt alkalmazva kicsiny (néhány \%) abszorpció-változás és inkoherens (sztohasztikus) folyamatok esetén

$$
\Delta \mathrm{A}(\lambda, \mathrm{t})=\sum_{\mathrm{i}, \mathrm{j}} \varepsilon_{\mathrm{S}_{\mathrm{i}} \rightarrow \mathrm{S}_{\mathrm{j}}}(\lambda) \cdot \Delta \mathrm{C}_{\mathrm{S}_{\mathrm{i}}}(\mathrm{t}) \cdot \mathrm{L}
$$

Ahol az $\mathrm{i} \rightarrow \mathrm{j}$ állapotok moláris extinkciós együtthatója $\varepsilon_{\mathrm{i} \rightarrow \mathrm{j}}$, és $\Delta \mathrm{C}_{\mathrm{i}}$ a koncentráció (populáció) különbsége $\left(\equiv \mathrm{P}_{\mathrm{ON}^{-}}-\mathrm{P}_{\mathrm{OFF}}\right)$ az $\mathrm{S}_{\mathrm{i}}$ állapotban. Ez az egyenlet csak akkor érvényes, ha az extinkciós koefficiens időfüggetlen, azaz nincs relaxáció vagy koherens folyamat, s ekkor az idő- és hullámhosszváltozók elkülöníthetőek egymástól. Leegyszerüsítve tehát megkapjuk, hogy $\mathrm{S}_{\mathrm{i}}$ állapotban több $\left(\Delta \mathrm{C}_{\mathrm{i}}>0\right)$ vagy kevesebb $\left(\Delta \mathrm{C}_{\mathrm{i}}<0\right)$ a populáció.

Összegezve tehát a mért adatok a pumpálás hatására bekövetkező gerjesztett állapotbeli és az alapállapotbeli abszorpció közti különbséget adják meg az idő függvényében. A detektált abszorpcióváltozás mögött a következő jelenségek húzódhatnak meg, melyet a 18 . ábrán szemléltetek: (1) alapállapot kifehéredése (ground state bleaching), (2) stimulált emisszió (SE), valamint (3) gerjesztett állapotbeli abszorpció (excited state absorption, ESA).

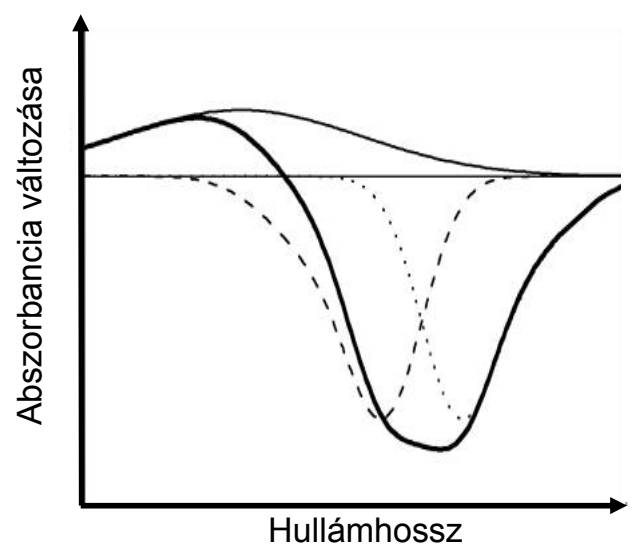

18. ábra - A detektált tranziens abszorpciós jel lehetséges értelmezésének szemléltetése: kifehéredés (szaggatott vonal), stimulált emisszió (pontozott vonal), gerjesztett állapoti abszorpció (szürke vonal), a folyamatok összege (vastag vonal) 
A 18. ábra, valamint a (2.28) egyenlet alapján tehát az alapállapot kifehéredése esetén $\Delta \mathrm{A}$ negatív, mert a koncentráció az $\mathrm{S}_{0}$ állapotban nagyobb pumpálás nélkül, ez a $\Delta \mathrm{C}_{\mathrm{S} 0}<0$-t eredményezi, míg $\mathrm{L}$ és $\varepsilon_{0 \rightarrow 1}>0$. Hasonló meggondolás alapján kapjuk, hogy SE esetén is $\Delta \mathrm{A}$ negatív, mert a koncentráció változása ugyan pozitív, de $\varepsilon_{1 \rightarrow 0}<0$. Az indukált abszorpció (ESA) is megjelenik a gerjesztett $\left(\mathrm{S}_{1}\right)$ és a magasabb $\left(\mathrm{S}_{\mathrm{n}}\right)$ állapotok között, ezesetben a $\Delta \mathrm{A}$ pozitív, mert a pumpálás miatt nő a populáció, és az $\varepsilon$ koefficiens is pozitív értékü.

Az időbontott abszorpció változásának tanulmányozására mindezek miatt az ultrarövid lézerimpulzusok alkalmazása a legmegfelelőbb, hisz így az impulzusoktól függően akár néhány 10 fs-os időfelbontással is tudjuk mérni a kinetikákat. Előny továbbá, hogy például fehér fény kontinuumot alkalmazva próba impulzusnak, a megfigyelt spektrum akár a közeli UV-tôl a teljes látható tartományon át (300-800 nm) információt adhat a molekula elektronállapotáról. 


\section{CÉLKITŰZÉSEK}

Biofizikai vizsgálataim egyik tárgya a bakteriorodopszin, a Halobacterium salinarum nevü archea egyik membránfehérjéje, amely az elmúlt 30 év számos biológiai és biofizikai kutatásának egyik legjelentősebb molekulája. A fehérje fény hatására protont pumpál az energiatermeléshez a baktérium számára. E funkciója során a bR-ben fényindukált törésmutató-változás lép fel. Ez a jelenség számos fotonikai felhasználási lehetőséget kínál, többek között az integrált optikában (tisztán optikai elven mőködő kapcsoló), az adattárolásban (polarizációs hologramok) és a nemlineáris optikában (másodharmonikus keltés). Másrészt több publikációban javasolták a fehérje fotoelektromos tulajdonságainak felhasználását is.

Annak ellenére, hogy számtalan helyen használják a bR-t, diszperziójára, valamint koncentrációfüggő törésmutatójára vonatkozó pontos mérési adatok az irodalomban nem állnak rendelkezésre. (1) Célul tüztem ki ezért a bR szuszpenzió koncentrációfüggö törésmutatójának meghatározását, valamint Sellmeier-típusú diszperziós egvenletek illesztését a teljes látható hullámhossz-tartományon. Méréseimet Dr. Osvay Károly irányítása alatt a Szegedi Tudományegyetem Optikai és Kvantumelektronikai Tanszékén található TeWaTi laborban összeállított femtoszekundumos titán-zafír lézer oszcillátorának impulzusaival végeztem, néhány mérésnél pedig nagynyomású xenon-lámpát használtam.

Napjaink kommunikációs hálózatainak adatforgalma és sebessége folyamatosan növekszik, jelenleg az 1 Tbit/s-os hálózat képviseli az elvárt sebességet és adatátviteli kapacitást. Általános vélemény, hogy a teljesen optikai adatátvitel az egyik legígéretesebb irány e cél eléréséhez. Az integrált optikai fejlesztések egyik kulcskérdése egy olyan, megfelelő nemlineáris optikai (NLO) tulajdonságokkal rendelkező anyag megtalálása, amely aktív szerepet tölthet be az integrált optikai áramkörökben. Az egyik új lehetséges jelölt lehet a bR, amely kedvező NLO tulajdonságai mellett optikai és mechanikai stabilitással is rendelkezik, és nem utolsósorban olcsó. (2) Célul tüztem ki a bR fotociklus szubpikoszekundumos $(<0.5$ ps) $\quad$ bR $\rightarrow I$ átmenetének vizsgálatát fehérje alapú integrált optikai eszköz megvalósítása céljából. Méréseimet OPCPA (optical parametric chirped-pulse amplification, optikai parametrikus fázismodulált impulzus erösítés) rendszerrel végeztem az SZTE Optikai és Kvantumelektronikai Tanszék TeWaTi lézerlaboratóriumában Dr. Osvay Károly és Dr. Dér András vezetésével. 
Az elmúlt években az MTA Szegedi Biológiai Kutatóközpont Biofizikai Intézetében Dr. Groma Géza vezetésével részt vettem egy új femtobiológiai laboratórium felépítésében, elsősorban a komplett femtoszekundumos lézerrendszer, valamint a fluoreszcencia kinetikai vizsgálatokhoz szükséges frekvencia-konverziós és egyfoton-számláló mérőberendezés megvalósításában. A létrejött mérőberendezés alkalmas a heterogén biológiai mintákban természetesen jelenlevő vagy mesterségesen bevitt kromofórok fluoreszcenciájának széles idő- és spektrális tartományban történő vizsgálatára, és ezen keresztül a kromofórok mikrokörnyezetében fellépő változások monitorozására. A legfontosabb autofluoreszcenciával rendelkező biomolekulák közzé tartozik a FAD és a NADH koenzim, amelyek a légzési lánc redox folyamataiban játszanak kulcsszerepet. A FAD és a NADH fluoreszcencia kinetika időálladóit széles körben alkalmazzák az egészséges és patológiás sejtek jellemzésére, ugyanakkor rendkívül kevés adat áll rendelkezésre arról, hogy a mikrokörnyezet egyes elemi paraméterei hogyan befolyásolják ezeket az időállandókat. Érdemes tehát körbejárni, hogy ezen molekulákon oldat fázisban az oldószerek polárosságának, H-kötéseinek és pH értékeinek változtatásával milyen változások lépnek fel fluoreszcencia jellemzőkben, és összehasonlítani a valós biológiai környezetben mérhető értékekkel. (3) Célul tüztem ki a FAD koenzim fluoreszcencia életidejének mérését a 100 fs -10 ns idötartományon különbözö mikrokörnvezetekben (különbözö oldószerekben illetve fehérjéhez kötve). Méréseimet a Magyar Tudományos Akadémia Szegedi Biológiai Kutatóközpontjában végeztem, femtoszekundumos oszcillátort használva fényforrásként. A mérési módszerek ismertetésénél bővebben beszámolok e komplett fluoreszcencia mérőrendszer felépítésének részleteiröl.

A NADH molekula két kromofórja között hatékony FRET folyamat tud létrejönni, melynek mértéke erősen függ a molekula konformációs állapotától. A gerjesztést követő intramolekuláris folyamatok pontosabb megértése céljából, a későbbi tervezett fluoreszcencia méréseket megelőzően (4) célom volt, hogy a NADH koenzim különbözö (nyitott és zárt) konformációs állapotait részletesen tanulmányozzam tranziens abszorpciós mérések alkalmazásával. Méréseimet a strasbourgi CNRS-IPCMS DON (Department of Optics and Nanophotonics) intézetben végeztem Prof. Stefan Haacke irányítása alatt. Méréseim során femtoszekundumos erősített lézerrendszer impulzusait használtam. 


\section{KÍSÉRLETI ANYAGOK ÉS MÓDSZEREK}

Munkám során femtoszekundumos fényforrásokat használtam, melyek titán-zafír oszcillátorok, illetve erősített lézerrendszerek voltak. Ebben a fejezetben sorra bemutatom az általam használt lézerek paramétereit, és a méréseim során alkalmazott kísérleti módszereket, mérési elrendezéseimet, továbbá a felhasznált biológiai minták előkészítésének módszereit. Részletesen ismertetem az általam felépített frekvencia konverziós és egy-foton számláló technikákon alapuló komplett fluoreszcencia mérőberendezést is.

\subsection{TÖRÉSMUTATÓ MEGHATÁROZÁSA FOLYADÉKOKBAN}

\subsubsection{KÉTKOMPONENSÜ FOLYADÉKOK TÖRÉSMUTATÓJA}

A bR preparálása során nyert bíbor membrán szuszpenzió optikai sűrüsége extrém nagy $(\mathrm{OD} \approx 17-60)$, ezért a fénytörés közvetlen mérése nehéz vagy lehetetlen. Méréseimet úgy végeztem, hogy a bR szuszpenziót különböző, meglehetősen alacsony koncentrációkra higítottam, amiből később visszaszámoltam a higítatlan minta törésmutatóját.

Minthogy az egyedi bíbor membránok vastagsága $(\sim 5 \mathrm{~nm})$ jóval kisebb a látható fény hullámhosszánál, a törésmutató meghatározása szempontjából a szuszpenzió olyan kétkomponensű folyadékoknak tekinthető, melynek összetevői nem lépnek kémiai reakcióba egymással. Ilyen keverékek törésmutatójának leírására az egyik leggyakrabban használt formula a Schwers (vagy Lattre) - egyenlet, amely a konkrét mintára alkalmazva [107]:

$$
\mathrm{n}_{\text {Mix }}\left(\lambda, \mathrm{V}_{\mathrm{bR}}\right)=\frac{\mathrm{V}_{\text {Mix }}}{\frac{\mathrm{V}_{\mathrm{bR}}}{\mathrm{n}_{\mathrm{bR}}(\lambda)}+\frac{\mathrm{V}_{\mathrm{TRIS}}}{\mathrm{n}_{\mathrm{TRIS}}(\lambda)}}
$$

ahol $n$ és $V$ a törésmutatót és térfogatot jelentik, a Mix, bR és TRIS indexek pedig rendre a higított bR szuszpenzióra, az izolált bíbor membránra és a TRIS pufferre utalnak. Így a puffer és az oldat törésmutatójának ismeretében az izolált bíbor membrán törésmutatója meghatározható.

Nagyon alacsony koncentrációkon (1-50 $\mu \mathrm{mol} / \mathrm{l})$ általában lineáris közelítést alkalmaznak [108, 109]: 


$$
\mathrm{n}_{\text {Mix }}\left(\lambda, \mathrm{C}_{\mathrm{bR}}\right)=\alpha(\lambda) \cdot \mathrm{C}_{\mathrm{bR}}+\mathrm{n}_{\mathrm{TRIS}}(\lambda),
$$

ahol $C_{b R}$ a bR szuszpenzió koncentrációja térfogat-százalékban, $\alpha(\lambda)$ pedig illesztési paraméter (specific refractive increment). A bR törésmutatója tehát meghatározható az $n_{b R}(\lambda)=n_{M i x}(\lambda, 1)$ értékeknél.

\subsubsection{A bR MINTA ELŐKÉSZÍTÉSE}

A mérésekhez a bR mintát a Szegedi Biofizikai Kutatóintézetből, szuszpenzió formájában kaptam. Méréseimhez ezt a mintát higítottam különbözö mértékben. A szuszpenziók aktuális koncentrációját az általánosan alkalmazott OD mérésekből állapítottam meg (2.25) alapján az $\varepsilon(568 \mathrm{~nm})=63000 \mathrm{M}^{-1} \mathrm{~cm}^{-1}$ érték alapján [110].

A különböző koncentrációjú bíbor membrán szuszpenziókat 10 mM-os Tris(hydroxymethyl)aminomethane (Sigma-Aldrich) pufferben készítettem el pH=7.0 értéken. Ennél a pH-nál a bíbor membránok aggregációja nem volt számottevő.

\subsubsection{A bR TÖRÉSMUTATÓ-MÉRÉSÉNEK KÍSÉRLETI MÓDSZERE}

A folyadékminta törésmutatójának meghatározását klasszikus refraktometriai módszerrel végeztem, a minimális deviáció szögének méréséböl [111]. A különbözö koncentrációjú bR szuszpenziókat egyenként üregprizmába tettem, majd a goniométerbe helyeztem. A szögek leolvasása kamerával történt - a nagyobb pontosság és a megfelelő infravörös érzékenység elérése érdekében. Hogy minél szélesebb spektrumon tudjak mérni, két különböző fényforrást használtam (19. ábra). A 390-780 nm közötti hullámhossztartományon 200 W-os átlagteljesítményủ Xe lámpa kollimált fényét használtam. A kívánt hullámhossz-értéket SPM2 monokromátorral állítottam be, ahol a spektrális sávszélesség mindvégig $0.4 \mathrm{~nm}$ volt - így a $60 \mu \mathrm{W}$ teljesítményủ megvilágítással megakadályoztam a minta gerjesztését, és a kifehéredést is kiküszöböltem $[112,113]$ a 390-780 nm közötti tartományon.

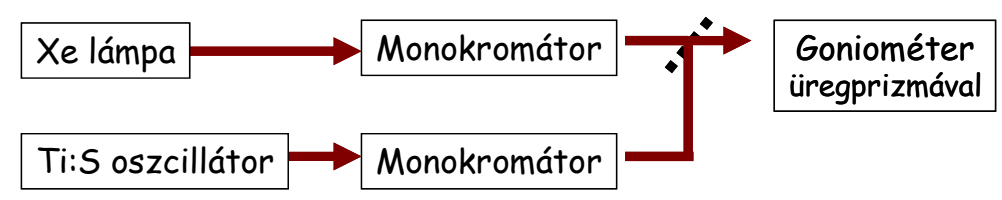

19. ábra - Kísérleti összeállitás sematikus rajza 
A 780-880 nm közötti hullámhossztartományon történő mérésekhez $70 \mathrm{MHz}$ ismétlési frekvenciájú, titán-zafír lézer oszcillátorának impulzusait használtam. A $100 \mathrm{~nm}$ spektrális félértékszélességű ( 18 fs) fényt egy Jobin Yvon H20UV monokromátorba vezettem (ahol a spektrális sávszélesség szintén $0.4 \mathrm{~nm}$ volt), majd leképeztem az üregprizma falára. Az impulzusvonulat átlagteljesítménye szürők használatával a mintánál mindvégig $10 \mu \mathrm{W}$ körüli érték volt. Tekintettel az alacsony intenzitásra, a többfotonos abszorpció nem játszott szerepet, a mérés alatt a bR mindvégig alapállapotban maradt. Méréseimet $22{ }^{\circ} \mathrm{C}$ hömérsékleten, $42 \%$ páratartalom mellett végeztem teljesen sötétben.

A mérési elrendezésben a goniométerhez érkező kvázi-monokromatikus forrásból érkező fény áthaladt a bemenő résen és a goniométer kollimátor lencséjén, így egy párhuzamos nyaláb haladt át az üres prizmán. A bemenő rést egy teleszkóppal a kamera síkjára képeztem és a goniométer skáláját nulláztam. Ezután a prizmát feltöltöttem a folyadékmintával és a minimális deviáció szögére állítottam, miközben a teleszkópból és kamerából álló egységet úgy forgattam, hogy a rés képének helye a kamerán ne változzon. Az egyes spektrumvonalakhoz tartozó elfordítás mértékét a nóniusz-skáláról olvastam le. A $\delta$ minimális deviáció abban a pontosan szimmetrikus esetben áll fenn, amikor a prizmára eső fény beesési szöge egyenlő a kilépési szöggel. A Snellius-Descartes-törvényt a törőfelületekre alkalmazva, a következő egyenlőség állítható fel:

$$
\mathrm{n}_{\text {liq }}=\mathrm{n}_{\text {air }} \cdot \frac{\sin \left(\frac{\delta+\phi}{2}\right)}{\sin \left(\frac{\phi}{2}\right)},
$$

ahol $n_{\text {liq }}$, és $n_{\text {air }}$ az üreges prizmában levő folyadék, ill. a levegö törésmutatója, $\phi$ pedig a prizma két megfelelő oldala által bezárt szög. Ez utóbbi egy HeNe lézerrel végzett méréssel $59.8 \pm 0.0017^{\circ}$-nak adódott. 


\subsection{ULTRAGYORS OPTIKAI KAPCSOLÁS BAKTERIORODOPSZINNAL}

\subsubsection{A PUMPA ÉS A PRÓBA IMPULZUSOK ELÖÁLLÍTÁSA}

A pumpa-próba méréseimet $10 \mathrm{~Hz}-\mathrm{es}$, TW-osztályú lézerrendszer $800 \mathrm{~nm}$-es impulzusaival végeztem, amelyeket két részre osztottunk (20. ábra).

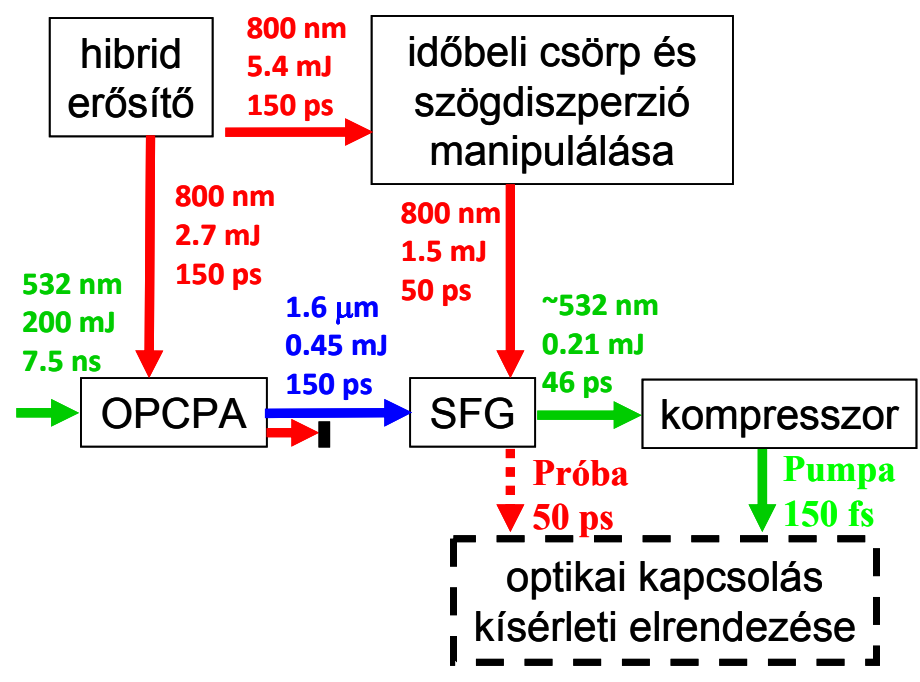

20. ábra - Az erősített zöld OPCPA rendszer sematikus rajza

Az intenzívebb részből optikai parametrikus fázismodulált impulzus-erősítés (OPCPA) és fázismodulált összegfrekvencia-keltés (chirp-assisted SFG) kombinációjával [114], kompresszálást követően állítottuk elő a 150 fs időtartamú, $80 \mu \mathrm{J}$ energiájú pumpa impulzusokat. A kompresszálást követően a pumpaimpulzusok spektrális és időbeli jellemzőit a 21. ábrán láthatjuk.

a)
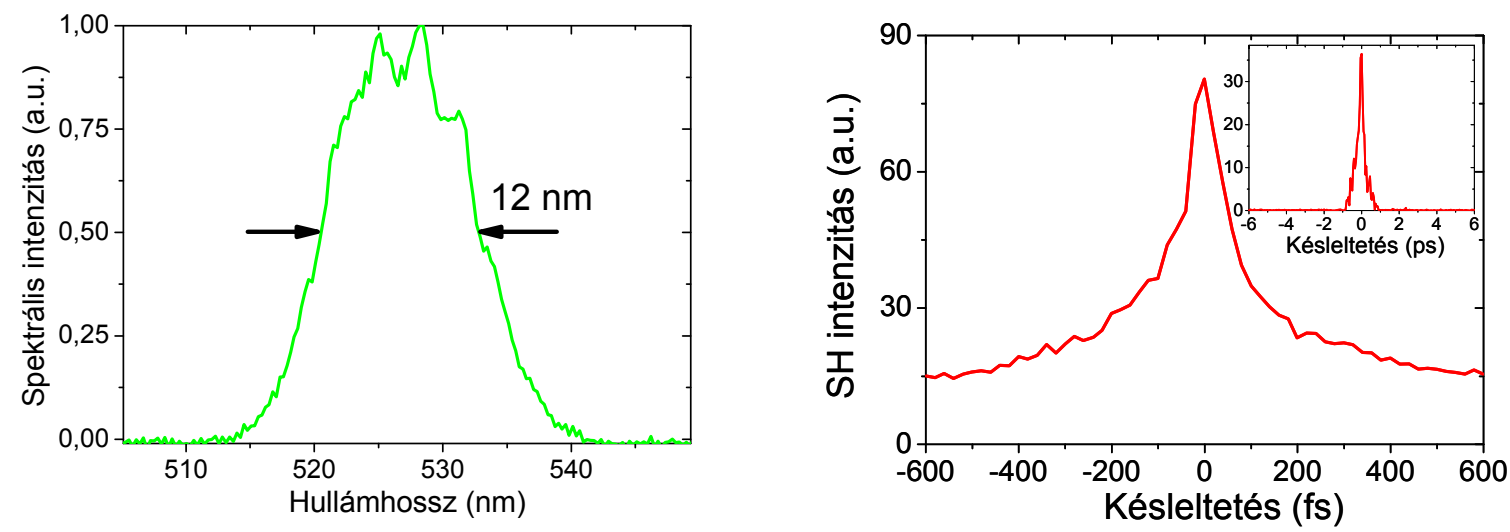

21. ábra - Az erősített pumpa impulzus spektruma (a) és a másodrendủ autokorreláció (b) $50 \mu \mathrm{m}$ vastag BBO használatával, belül a 12 ps-os időablak nagyítása látható. 


\subsubsection{A KAPCSOLÁS MEGVALÓSÍTÁSÁNAK KÍSÉRLETI ELRENDEZÉSE}

Ezzel a szélessávú (21.a ábra), zöld impulzussal a bR abszorpciós sávját gerjesztettem 530 nm-es központi hullámhosszon, elindítva a fotociklust. Az SFG kristályon áthaladó, $800 \mathrm{~nm}$ es, $1 \mu \mathrm{J}$-os próba impulzus spektrális sávszélessége $1800 \mathrm{~mm}^{-1}$-es arany rács, egy optikai rés, illetve Fabry-Perot-interferométer (finesse $\approx 50$ ) alkalmazásával $0.2 \mathrm{~nm}$, transzformációlimitált időbeli félértékszélessége pedig 3 ps volt (22.a ábra). Az impulzusokat megfelelő késleltetés után egy szárított bR filmmel bevont rácsos csatolású sík hullámvezetőre irányítottam (22. $a$ és $b$ ábra). A hullámvezetőbe a megfelelő beesési szög alatt becsatolt fény intenzitásváltozását egy gyors fotodiódával (Thorlabs, DET10A) és egy sokcsatornás analizátorral (LeCroy WaveRunner 6100A) mértem.

A méréseim során optikai hullámvezetőt (Oerlikon Balzers) használtam, amely egy üveghordozóból $\left(N_{S} \approx 1,51\right)$ és egy vékony $(d \approx 200 \mathrm{~nm})$, nagy törésmutatóval rendelkező dielektromos anyagból $\left(\mathrm{TiO} 2, n_{F} \approx 1,72\right)$ készült vezető (film)rétegből állt. A hullámvezető rétegbe való becsatolás diffrakciós ráccsal (2400 vonal $/ \mathrm{mm})$ történt, amelyet a szubsztrát-film határfelületre integráltak (22. $b$ ábra). Megfelelő feltételek mellett a fény becsatolása az elsőrendü diffrakció alkalmazásával valósítható meg. A TE és TM módusok esetén csak pontosan meghatározott beesési szögeknél teljesül a hullámvezetés [40, 91].

(a)

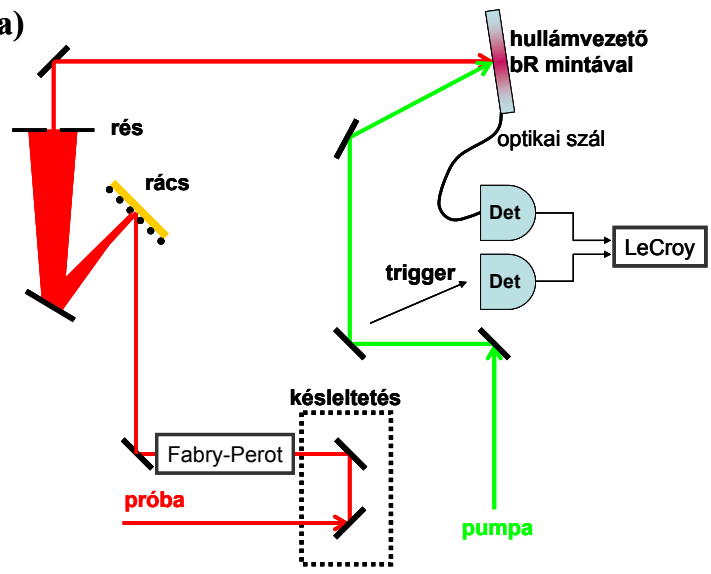

(b) bR adlayer hullámvezetô réteg

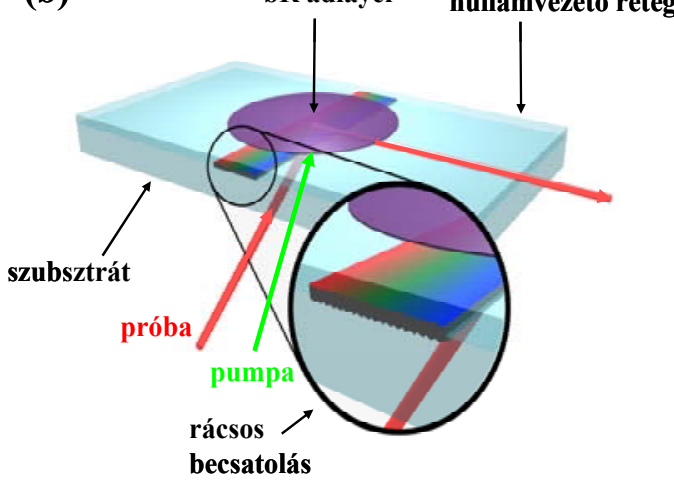

22. ábra - (a) Kísérleti elrendezés. Az optikai kapcsolást $530 \mathrm{~nm}$ pumpa impulzussal valósítottuk meg, az effektust a $790 \mathrm{~nm}$ központi hullámhosszú próba impulzusokkal vizsgáltuk. A pumpálás hatására bekövetkezö intenzitásváltozást gyors fotodiódával és oszcilloszkóppal detektáltuk. (b) Az optikai kapcsolás sematikus rajza 


\subsection{IDŐBONTOTT FLUORESZCENCIA SPEKTROSZKÓPIAI MÉRŐRENDSZER}

\subsubsection{A MINTÁK ELŐKÉSZÍTÉSE}

A FAD mintát a Sigma-Aldrich vállalattól rendeltem. Méréseimhez minden nap friss $3 \cdot 10^{-3}$ M-os törzsoldatot készítettem $50 \mathrm{mM}-\mathrm{os}, \mathrm{pH}=7.0$ foszfát pufferben. Ezután az eredeti pufferrel, valamint dioxánnal, etanollal és DMSO-val 1:1 arányban higítottam a FAD törzsoldatot. Így méréseim során a FAD koncentrációja mindvégig $1.5 \cdot 10^{-3} \mathrm{M}$ volt. A kötött FAD-ot tartalmazó flavocitokróm C (Flavocytochrome C, FCC) fehérjét Dr. Bagyinka Csaba (SZBK, Biofizikai Intézet) preparálta.

\subsubsection{A FREKVENCIA KONVERZIÓN ÉS TCSPC TECHNIKÁN ALAPULÓ MÉRÉSEK TERVEZÉSE, KÍSÉRLETI ÖSSZEÁLLÍTÁSA}

Az időfelbontásos fluoreszcencia mérésekre laboratóriumunkban a közelmúltban egy titánzafír oszcillátoron (FemtoRose 100 TUN, R\&D Ultrafast Lasers, Hungary) alapuló kombinált mérési elrendezés építésében vettem részt, amely a fluoreszcencia kinetikát a frekvencia konverziós és a TCSPC módszerével egyaránt képes mérni. Részletesen a mérési elrendezést a 23. ábra mutatja. Az első módszer előnye a nagy időfelbontás (készülékünkön 200 fs), azonban ennek a nemlineáris összegfrekvencia keltésen alapuló módszernek kicsi az érzékenysége. A TCSPC eljárás időfelbontása lényegesen rosszabb (készülékünkön 40 ps), érzékenysége viszont nagyságrendekkel meghaladja az előző módszerét, így a két technika kombinálása jól kiegészíti egymást.

A titán-zafír oszcillátorból érkező 800 nm-es 650 mW átlagteljesítményü, p-polarizált impulzusokat egy nyalábosztó segítségével két egyenlő részre osztottam. Az egyik rész a továbbiakban kapuimpulzusként, a másik pedig optikai pumpaként szolgált. A pumpakarban haladó impulzusok polarizációját $\lambda / 2$ lemez segítségével s-polarizációba forgattam, majd egy $600 \mu \mathrm{m}$ vastag BBO (a 23. ábrán SHG) kristályban másodharmonikust keltettem I. típusú fázisillesztéssel. Így méréseim során a mintáimat gerjesztő p-polarizált impulzus hullámhossza $400 \mathrm{~nm}$ volt. 


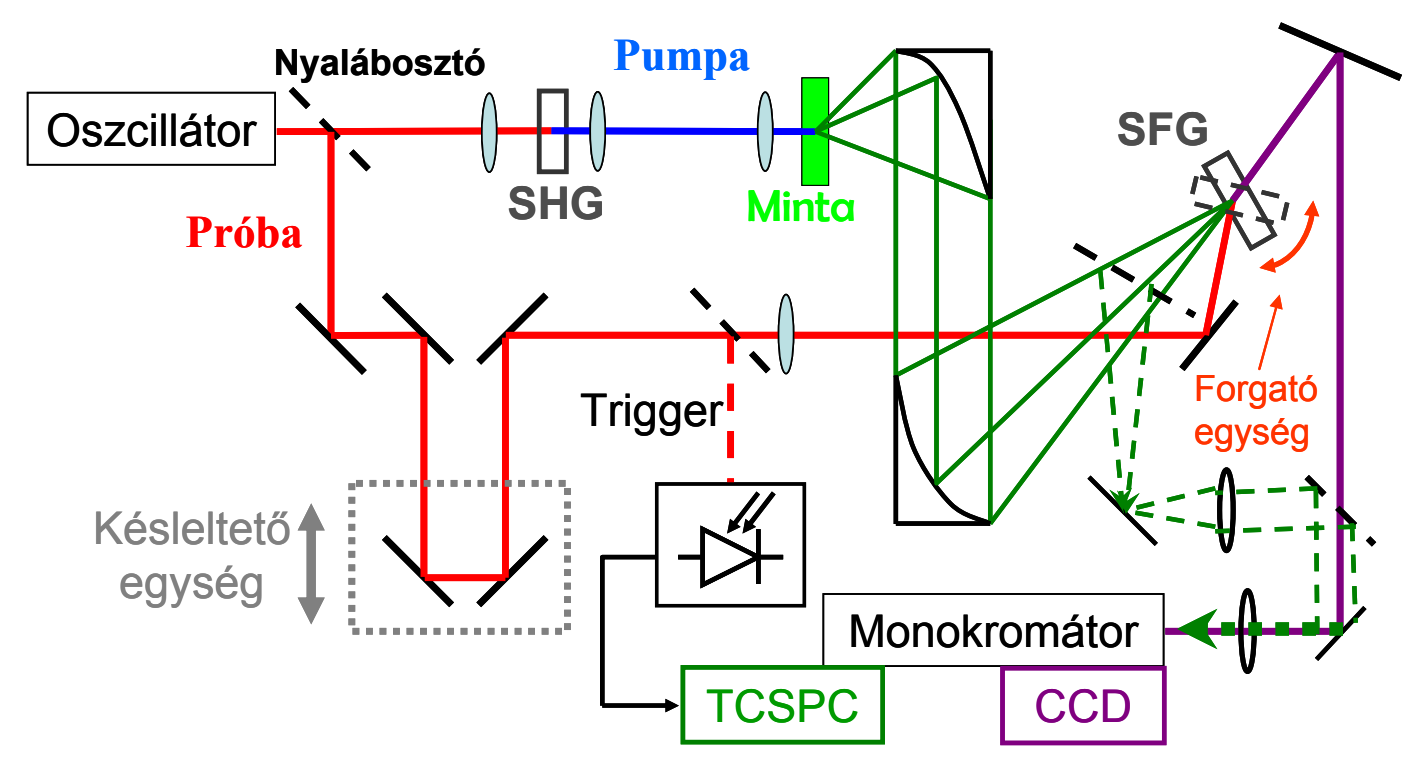

23. ábra - „Kettő az egyben” mérési elrendezés: időbontott fluoreszcencia mérésére alkalmas rendszer fejlesztése 100 fs - 10 ns időtartományban. A kétféle elrendezés csak a minta után különbözik, a kettő között csapótükörrel lehet átváltani. A folytonos vonal a frekvencia konverziós megoldást szemlélteti (rövid, 1 ns alatti időtartományon), a szaggatott vonal pedig a TCSPC technikát mutatja (100 ps - 10 ns közti időtartományon).

A gerjesztő fény károsító hatásának minimalizálása érdekében, a folyadék állapotú minta mindkét elrendezésben egy $1 \mathrm{~mm}$ vastag, négyzet alapú kapillárisban áramlott egy perisztaltikus pumpa segítségével. A mintában a fókuszált gerjesztő fény $24 \mu \mathrm{m}$ átmérőjü volt. Az emittált fluoreszcenciát egy nagy apertúrájú (3 inch átmérőjü) off-axis parabolatükörpár (JanosTech, 300-750 nm AR coating) segítségével gyüjtöttem össze, majd fókuszáltam. A tükörpár alkalmazásának nagy előnye, hogy a tipikus leképezési hibáktól mentes (pl. színi vagy szférikus aberrációk, asztigmia, stb.). Az első tükör $5 \mathrm{~cm}$ effektív fókusztávolságú és $90^{\circ}$-ban kivágott parabola, amely összegyüjti a nagy térszögből érkező fluoreszcenciát és kollimálja. A második tükör (30 cm effektív fókusztávolság, 30-os deviáció) azonos átmérőjü az elsővel, és a kollimált fényt az összegfrekvencia keltésre használt BBO kristályra fókuszálja (a 23. ábrán SFG). A parabola-pár nagyítása 1:6 arányú, így a fókuszban $180 \mu \mathrm{m}$ volt a fluoreszcencia fény nyalábnyak mérete.

A parabola-pár beállításánál szem előtt kell tartani, hogy méréseink során a keltett összegfrekvencia komponens nem látható, valamint az első parabola fókusztávolsága kicsi az átmérőjéhez képest, így a mélységélessége is kicsi $(1.6 \mu \mathrm{m})$. Tehát meg kell találnunk az első valamint a második parabola tükör fókuszsíkjainak nagyon precíz pozícióját, hisz az első tükör fókuszsíkjában a mintát, a másodikéban pedig a BBO kristályt kell nagy pontossággal 
beállítani. A pontos fókuszpontok helyének megkeresésére $10 \mu \mathrm{m}$ pinhole-t használtam, amelyet a pumpa impulzust fókuszáló lencse mögött helyeztem el a fókuszpontban 3 dimenziós eltolón. Az intenzív nyaláb áthaladt a pinhole-on, ami kisebb volt, mint a fókuszpont. Majd a megfelelő pozíciót a pinhole 3D mozgatásával kerestem meg teljesítménymérő segítségével, amelyet rögtön a pinhole mögött helyeztem el. A maximális teljesítmény megtalálása jól definiálja a fókuszpont helyét. A precíz beállítás ezután pausz papír szórt fényével történt a következő sorrendben.

1. Elsö parabola tükör beállítása: A pausz papírt a várható minta-pozícióba helyeztem (a pumpa impulzus fókusza), hogy szimuláljak egy pontszerü fényforrást. Majd behelyeztem a megfelelő fókusztávolságban az első parabola tükröt, és addig mozgattam, míg kb. 6 méter távolságban a reflektált fény a tükör átmérőjével megegyezett, valamint éles, kör alakú lett.

2. Második parabola tükör beállitása: A második tükröt $30 \mathrm{~cm}$ távolságra a kollimált fény útjába helyeztem, hogy a fényt fókuszálja. Háromszög módszerrel kimértem a 30 fokos nyílásszögét.

3. A második tükör preciz fókuszpontjának meghatározása: A második tükör fókuszsíkjának (MFS) pontos helyét pinhole segítségével határoztam meg.

4. Az első tükör preciz fókuszpontjának meghatározása: Az első tükör fókuszsíkjának (EFS) pontos helyzetét könnyen megtalálhatjuk egy másik lézersugár visszaküldésével. Az MFS-be most pauszt helyeztem, és a visszafele irányított szórt fény fókusza kijelöli az EFS-et. A pontos helyzetet az EFS-be helyezett pinhole beállításával határozhatjuk meg.

5. A pumpa fókuszának újradefiniálása: A pumpa fókuszának egybe kell esnie az első parabola tükör fókuszával az EFS-ben. A fókusz pozícióját korrigálhatjuk a lencsével úgy, hogy a pumpa ez előző esetben behelyezett pinhole-ra fókuszál.

A 24. ábán összefoglaltam az első és második parabola tükör fókuszsíkjának meghatározását. A helyes beállítást követően az EFS-ba helyeztem a kapillárist $2 \mathrm{D}$ eltolón (mivel a kapillárisban áramoltatott mintáinkat az optikai tengely és a horizontális tengely mentén kell mozgatni). Az MFS helyére pedig motoros forgatón helyeztem el az SFG-t végző BBO kristályt. 

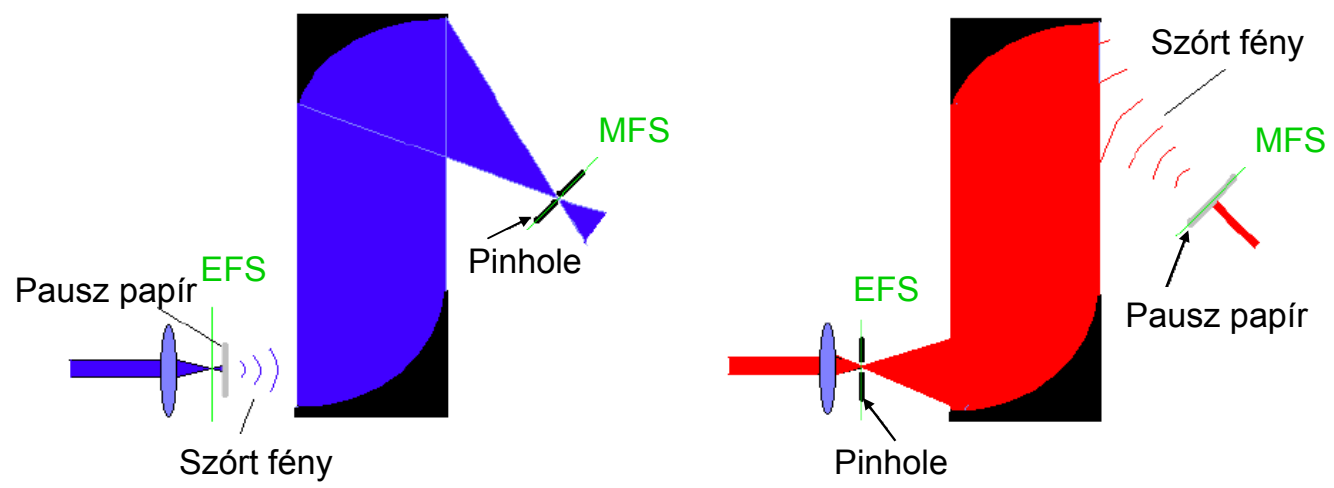

24. ábra - Az off-axis parabola tükrök fókuszsíkjának meghatározása (EFS: első tükör fókuszsíkja; MFS: második tükör fókuszsíkja)

\section{A FREKVENCIA KONVERZIÓN ALAPULÓ MÓDSZER}

A felkonvertálásos elrendezésben kapuzó (próba) impulzusként a lézer alapharmonikusából kicsatolt másik nyalábot használtam (25. ábra), mely egy $150 \mathrm{~mm}$ hosszú, motoros késleltető egységen (Newport, UTS széria, 0.1 um felbontás) áthaladva ugyancsak a BBO kristályra fókuszálódott ( $\mathrm{f}=500 \mathrm{~mm}$, nyalábnyak $160 \mu \mathrm{m})$. A megfelelő pontosságú beállítás érdekében a kristály mögött egy kamerát helyeztem el, amellyel megfigyelhető a két fókuszpont térbeli átfedése.

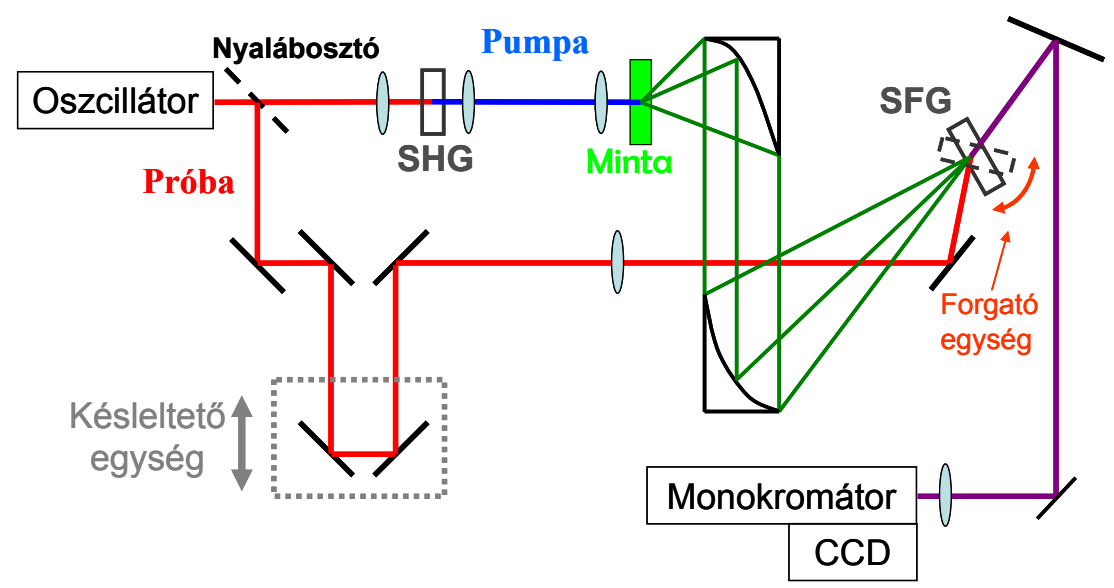

25. ábra - A frekvencia konverzión alapuló kísérleti elrendezés

A frekvencia konverzióhoz használt BBO kristály paramétereit I. típusú fázisillesztés alkalmazásánál az SNLO szoftver [115] segítségével határoztam meg (2. táblázat). A kristály hosszát $(600 \mu \mathrm{m})$ a lézernyaláb fókuszált nyalábnyakához igazítottam [116]. Mivel a fluoreszcencia fény széles spektrális tartománnyal bír, a megfelelő frekvenciák összegzéséhez 
szükséges fázisillesztést a kristály forgatásával biztosítottam. A forgatásához motoros forgatót (Newport, URS széria, $0.001^{\circ}$ pontosság) használtam. A forgatás miatt a kristály $\theta$ fázisillesztési szögét a (2.23) alapján $35^{\circ}$ - nak választottam, hogy a mérendő fluoreszcencia tartomány közepén legyen ( 530 nm konverziójának felel meg), így a kristállyal a teljes látható tartományból érkező fluoreszcencia fényt tudjuk konvertálni.

\begin{tabular}{|c|c|c|c|}
\hline NYALÁBJELLEMZÖK & KAPUIMPULZUS & FLUORESZCENCIA & ÖSSZEGFREKVENCIA \\
\hline Központi hullámhossz [nm] & $795.0(0)$ & $530.0(0)$ & $318.0(\mathrm{e})$ \\
\hline Walkoff [mrad] & 0.00 & 0.00 & 79.30 \\
\hline Fázissebesség [c/...] & 1.661 & 1.674 & 1.669 \\
\hline Csoportsebesség [c/...] & 1.685 & 1.722 & 1.809 \\
\hline $\mathrm{GDD}\left[\mathrm{fs}^{2} / \mathrm{mm}\right]$ & 75.8 & 136.8 & 294.3 \\
\hline$\theta[$ fok $]$ & & & 36.9 \\
\hline Szögtolerancia $\left[\mathrm{mrad}^{\circ} \mathrm{cm}\right]$ & & & 0.24 \\
\hline
\end{tabular}

2. táblázat - A fluoreszcencia frekvencia konverzióhoz használt nyaláboknak az alkalmazott BBO kristály által meghatározott paraméterei

Az összegfrekvencia keltés során a legkritikusabb pont a fázisillesztetlenség. A gyakorlatban nem-kollineáris geometriával könnyebben kiküszöbölhető ez a probléma $[117,118]$. A megfelelő időfelbontás és térbeli szürés miatt az ideális beesési szöget a két nyaláb között 12 foknak terveztem, $600 \mu \mathrm{m}$ vastagságú kristály esetén. A belső reflexiókat elülső és hátsó fali antireflexiós bevonatokkal küszöböltük ki. A kristály mögött réssel és UG11 sávszürőkkel mind térben, mind spektrálisan elimináltuk a pumpa- és kapuimpulzusokat.

A kristályban keletkező összegfrekvencia nyalábot egy monokromátor (Horiba Jobin Yvon, iHR550) résére fókuszáltam egy $35 \mathrm{~mm}$-es fókusztávolságú fused silica lencsével (AR 250-400 nm). A monokromátor - két kimenő portja közül az - egyik kimenetén egy folyékony nitrogénnel hütött 1024x256 pixelü CCD detektor helyezkedett el (Horiba Jobin Yvon, Symphony), biztosítva a teljes spektrum egyidejü detektálását. A spektrális bontáshoz $300 \mathrm{vonal} / \mathrm{mm}$-es rácsot használtam.

A detektálás során a fázisillesztés biztosítása érdekében a BBO kristályt a kívánt hullámhossztartományban a rotátor forgatta. A mérések során mindvégig egy adott kristálypozícióban megmértem a kinetikát különböző késleltetéseknél, majd a kristályt a következő pozícióba mozgattam. Ennek ismétlésével a nyert adatok a fluoreszcencia 
intenzitás idő- és spektrális függését tartalmazták. A kristály szögének hullámhossz kalibrációját (annak a szögnek a megállapítását, amelynél egy adott hullámhosszon az összegfrekvencia keltése maximális) a 400-760 nm spektrális tartományon C102, C153 és Pyridine lézerfestékek fluoreszcenciájának mérése során hajtottuk végre.

A $\mathrm{t}=0$ késleltetés megkeresését a lézer harmadik harmonikusának beállításával biztosítottam $\left(\theta \approx 42^{\circ}\right)$ oly módon, hogy a pumpa nyaláb fókuszsíkjába pausz papírt helyeztem. A beállítást megismételtem Ludox-szal (40 wt. \% colloidal silica suspension in $\mathrm{H}_{2} \mathrm{O}$ ) töltött kapilláris elhelyezésével is. Ezután az eltoló mozgatásával meghatároztam a harmadik harmonikus idő- és hullámhossz szerinti eloszlását. Ezáltal megkaptam a mérőkészülék időbeli felbontására jellemző keresztkorrelációs függvényt.

\section{A FOTONSZÁMLÁLÁSON ALAPULÓ MÓDSZER}

A TCSPC elrendezésben a parabolatükrökkel összegyüjtött fluoreszcencia fényt kollimáltam (3:1 kicsinyítés alkalmazva), majd közvetlenül a monokromátor belépő résére leképeztem 150 mm fókusztávolságú lencsével (26. ábra). A gerjesztő impulzus maradványát felüláteresztő szürőt (FGL435) alkalmazva elimináltam a fluoreszcencia fényből. A monokromátor második kimenő portján egy lavina (avalanche) fotodióda (IDQuantique, ID-100) helyezkedett el az egyfoton számlálást végrehajtó elektronikai egységhez kapcsoltan (Becker\&Hickl GmbH, SPC-130). Ebben az elrendezésben a fluoreszcencia kinetikákat a kívánt hullámhosszakon egymás után lehetett felvenni a monokromátor rácsának elforgatásával. A mérések kezdetén mindig kimértem a rendszer átviteli függvényét a gerjesztő, azaz a $400 \mathrm{~nm}$ központi hullámhosszú impulzussal, ami a mi elrendezésünk/detektorunk esetén mindvégig 40 ps-nak adódott.

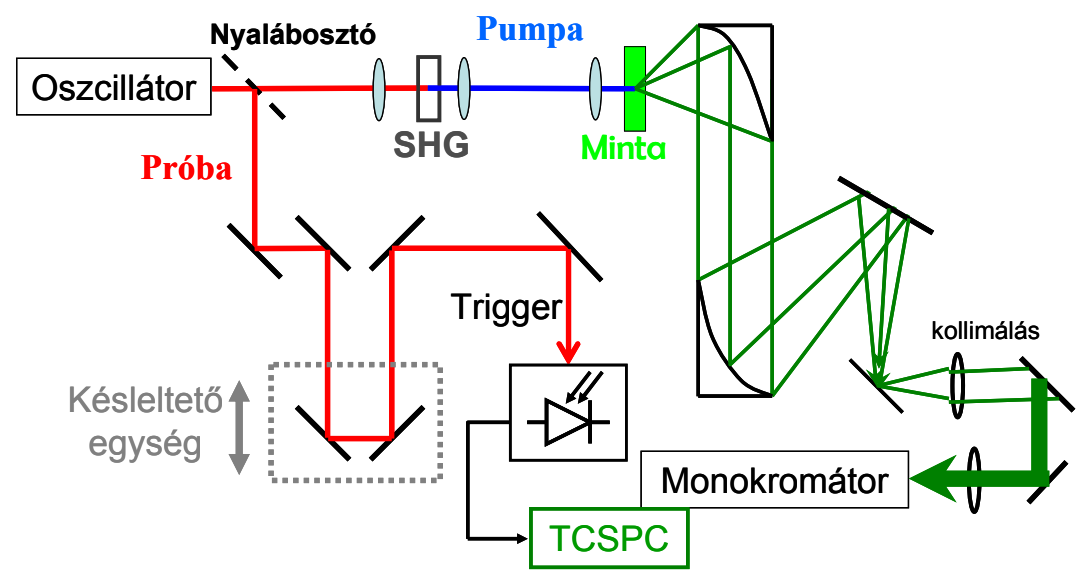

26. ábra - A foton számláláson alapuló kísérleti elrendezés 
A felkonvertálásos illetve TCSPC kísérletek során az eltoló és forgató motorok szabályzását, a monokromátor beállítását, a CCD kamera valamint a TCSPC egység adatainak kiolvasását, az adatok előfeldolgozását és grafikus megjelenítését egy egységes virtuális kezelőfelülettel ellátott Labview program (National Instruments) végezte. A teljes mérési elrendezés fotóját a 27. ábrán mutatom be.

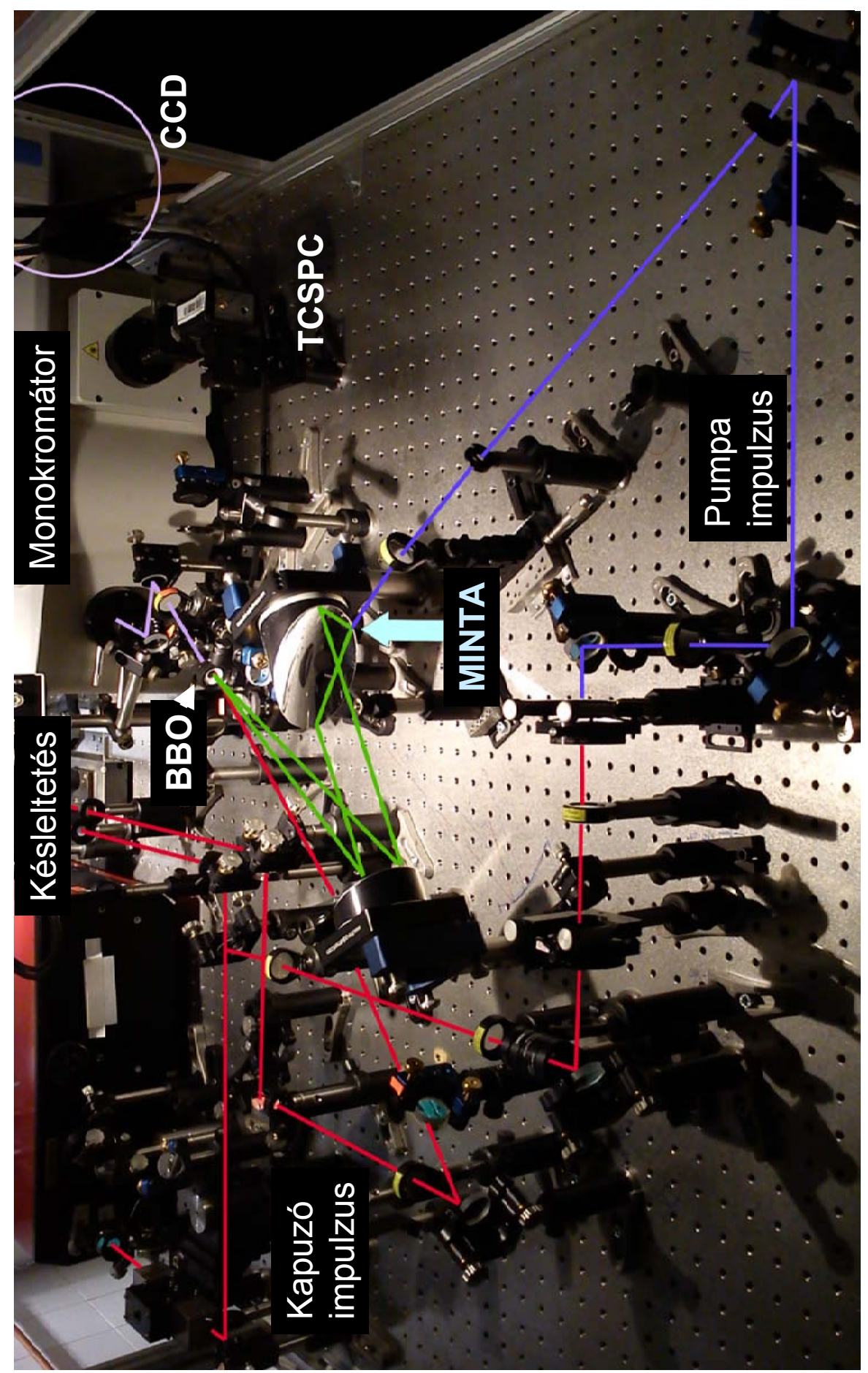

27. ábra - A felépített komplett fluoreszcenciát mérö berendezés (Femtobiológiai Laboratórium, Biofizikai Intézet, MTA SZBK) 


\subsubsection{AZ ADATOK KIÉRTÉKELÉSE}

Mint az előzőekből látható, az időfelbontásos spektroszkópiai méréstechnikák során nyerhető nyers adatok a fényintenzitás idö- és hullámhossz függése, mely egy $I(\lambda, t) 2 D$ mátrixba rendezhető. Fluoreszcencia kinetikák kiértékelése eredményeképpen a gerjesztett állapot(ok) élettartamát és a hozzájuk tartozó amlitudók spektrális eloszlását kell meghatároznunk.

A FAD mintákon a fluoreszcencia kinetikákat mindkét (frekvencia konverzió, egyfoton) módszerrel megmértem. A felkonvertálás esetében a késleltetési pontok $1 \mathrm{~ns}$-ig logaritmikus skálán egyenletesen helyezkedtek el. A zajcsökkentés érdekében az így nyert adatokon az SVD módszerrel szürést hajtottam végre. A TCSPC módszerrel a lézer 76 MHzes ismétlési frekvenciája 13 ns-ig terjedő mérési tartományt engedett meg, melyen utólag logaritmikus kompressziót alkalmaztam. A két mérési módszerrel nyert adatokat a 100 ps -1 ns átfedő időtartományban összeillesztettem, és egymáshoz füztem. Az összefüzés során megtartottam a TCSPC adatok eredeti amplitúdóját (detektált fotonok száma), és ehhez normáltam a felkonvertálással nyert adatokat. Ez biztosította a mérőkészülék spektrális átvitelére való egyszerü korrekciót a gyári adatok (monokromátor, lavinadióda) alkalmazásával. Az időtengely nulla késleltetését ( $\mathrm{t}_{0}$ ) Gauss-függvény és egy exponenciális konvolúciójából határoztam meg minden egyes hullámhosszon, figyelembe véve a csörpöt is. A háttérkorrekciót pedig a negatív időtartományra ( $\mathrm{t}=0$ előtt $)$ megállapított átlagintenzitásból számoltam.

$\mathrm{Az}$ adatok kiértékelése ezután több lépésben történt. A lényegesebb beállítási lépéseket, az adatsorok főbb analíziseit és a kinetikák kiértékelésére vonatkozó matematikai formalizmust az alábbiakban összefoglalom.

\subsubsection{AZ IDÖFELBONTÁS, ÁTVITELI FÜGGVÉNY}

Az egyes spektroszkópiai módszerek térbeli és időbeli felbontása erősen függ a kísérleti elrendezéstől. Egy adott beállításnál a készülék átviteli függvényén (IRF, Instrument Response Function) a mérörendszernek egy végtelenül rövid impulzusra (Dirac delta jel) adott válaszát értjük, amelyről az alábbiakban feltételezzük, hogy jól közelíthető egy Gaussfüggvénnyel. Az IRF a lavinadióda esetén föként elektronikai jellegü, míg a femtoszekundumos pumpa-próba illetve fluoreszcencia frekvenciakonverziós technikáknál a pumpa és próba (vagy a fluoreszcenciát gerjesztő és a kapuzó) impulzus közti keresztkorrelációs függvény (CCF, cross-correlation function) definiálja. A CCF valójában a 
két impulzus $(\mathrm{x}(\mathrm{t})$ és $\mathrm{y}(\mathrm{t}))$ átfedése a $\tau$ késleltetés függvényében. Matematikai definíciója a következő:

$$
\operatorname{CCF}(\tau)=\int_{-\infty}^{+\infty} x(t) \cdot y(t+\tau) d t
$$

A frekvenciakonverziós technikánál az áviteli függvény az előbbiekben leírt harmadik harmonikus keltéssel határozható meg. Esetünkben ez jól közelíthető volt egy 250 fs félértékü Gauss-függvénnyel (28. ábra).
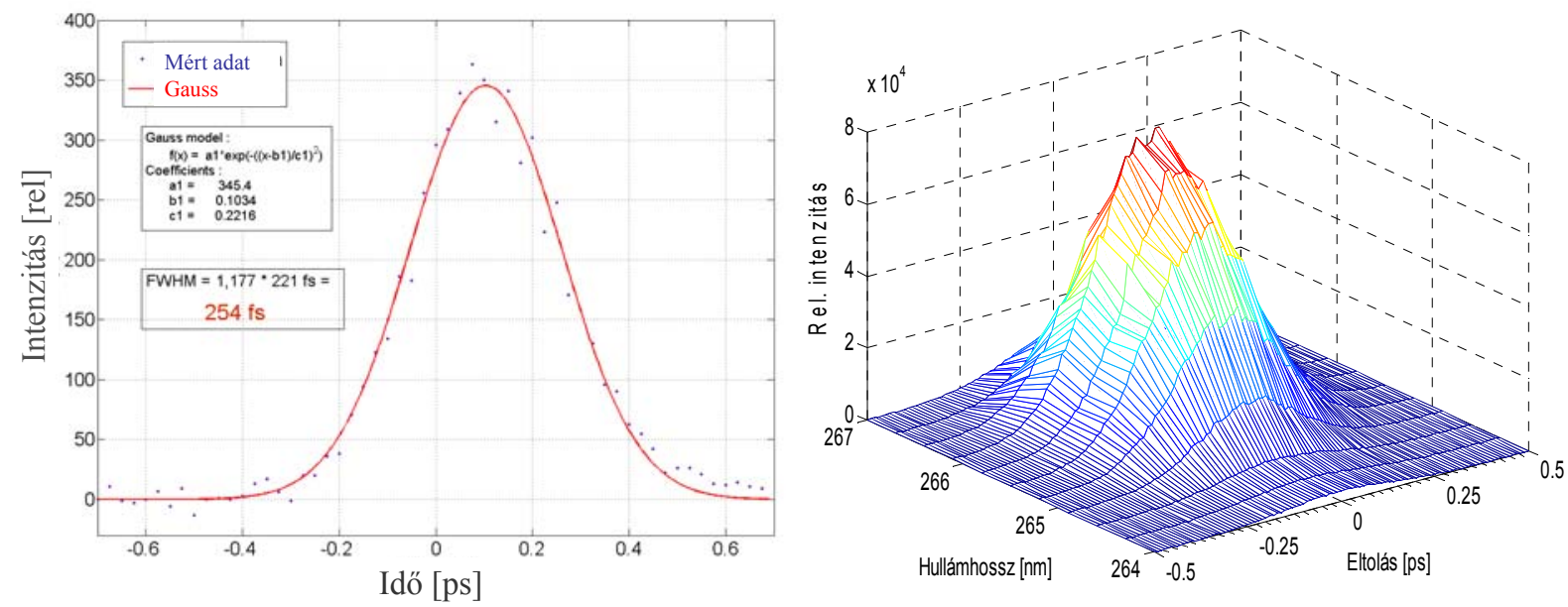

28. ábra - A frekvencia konverziós mérések átviteli függvénye

A TCSPC eljárás átviteli függvényét a pumpa impulzus közvetlenül mért válaszjeléből határozhatjuk meg [100], melynek félértéke esetünkben $38( \pm 4)$ ps-nak adódott (29. ábra), jó egyezésben a gyári specifikációval ( $<40$ ps).

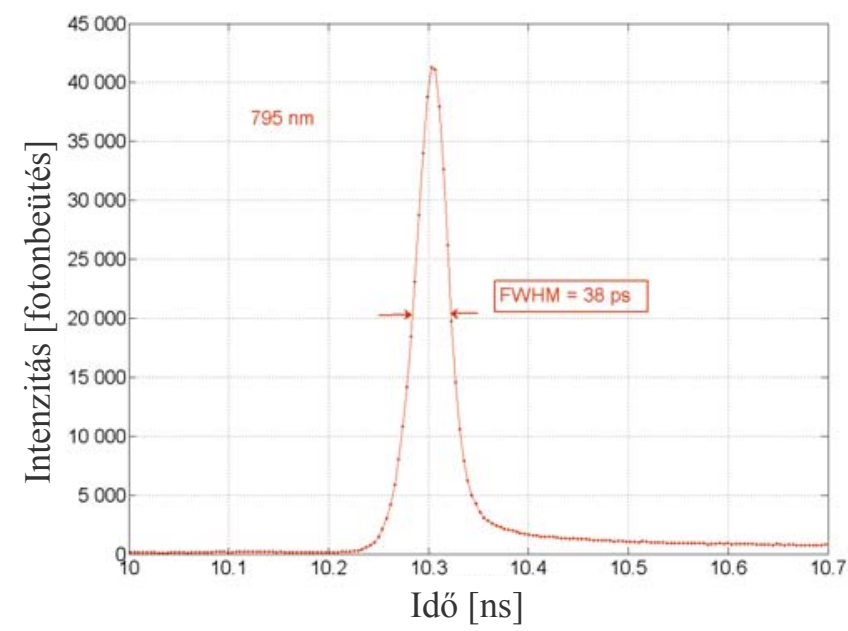

29. ábra - A TCSPC mérések átviteli függvénye 


\subsubsection{ZAJSZÜRÉS AZ SVD MÓDSZERREL}

A szinguláris értékek szerinti felbontás (SVD, Singular Value decomposition) gyakran alkalmazott módszer a zaj csökkentésére. A módszer akkor alkalmazható, ha a zajos jel egy mátrixszal reprezentálható. Mint említettem, az időfelbontásos spektroszkópiával nyert adatok általában egy $\mathrm{n} \times \mathrm{m}$-es $\mathrm{M}_{\mathrm{nm}}$ mátrixba rendezhetők, ahol a sorok a különböző időpontokban, az oszlopok pedig a különböző hullámhosszon a mért intenzitás(változás)okat tartalmazzák. Az SVD felbontja az $M$ mérési mátrixot $U_{S V}^{t}-r e$, ahol az U unitér mátrix, $S$ a diagonális mátrix és $\mathrm{V}^{\mathrm{t}}$ egy másik transzponált unitér mátrix [119]:

$$
\mathrm{M}_{\mathrm{nm}}=\mathrm{U}_{\mathrm{nn}} \mathrm{S}_{\mathrm{nm}} \mathrm{V}_{\mathrm{mm}}^{\mathrm{t}}
$$

Itt a $\mathrm{V}^{\mathrm{t}}$ oszlopai tartalmazzák az egyes spektrumokat, az U oszlopai pedig az egyes tranzienseket. Az S diagonális mátrixról megmutatható, hogy annak főátlójában levő szinguláris értékek közül a kisebbek főleg a jel zajkomponenseit reprezentálják. Ezen kicsiny szinguláris értékek elhanyagolásával, és az így nyert új SVD mátrixot inverz transzformálva a jel zajtartalma csökkenthetö.

\subsubsection{A MÉRŐRENDSZER OPTIMALIZÁLÁSA ÉS KALIBRÁCIÓJA LÉZERFESTÉKEKKEL}

A biológiai minták flureszcenciája általában szemmel nem látható, hiszen a biológiai anyagok fluoreszcenciájának kvantumhatásfoka általában kicsi, illetve a sejtek számát nem lehet elég nagy értékre növelni ahhoz, hogy mintánk megfelelő OD-jü legyen. Ennek következtében a mérések előtt a mérőrendszerünk beállítását célszerü lézerfestékekkel optimalizálni, és erre egy jó beállítási algoritmust kell találni.

A FAD méréseket megelőzően tehát tesztméréseket végeztem Malachite Green és Coumarin 153 (C153) lézerfestékek fluoreszcencia életidejének meghatározására [120].

Először a Malachite Green festék időbontott fluoreszcencia spektrumát mértem meg a frekvencia konverziós eljárással. Ennek oka az volt, hogy az irodalom alapján a várt életidők nagyon rövidek, a fluoreszcencia (szokatlan módon az $\mathrm{S}_{2} \rightarrow \mathrm{S}_{0}$ átmenet során) a néhány pikoszekundumos tartományban lecseng [121-123]. Ezért jó megoldásnak tűnt a frekvencia konverziós rendszerünk és kiértékelési algoritmusunk ellenőrzésére. A mért időbontott spektumokat a 30. ábra mutatja. A spektrumok kiértékelése során figyelembe vettem a használt UG11-es Schott szürők, a monokromátor rácsa, valamint a CCD kamera spektrális átvitelét, melyekkel korrigáltam a mért adatokat. Emellett a mintán átmenő 400 nm-es 
gerjesztő impulzussal összegfrekvenciát keltve kimértem a CCF-et, mellyel a késleltetéseket korrigáltam. A kiértékelést követően eredményeim teljes egyezést mutattak az irodalomban közölt életidőkkel (250 és 730 fs) [124], és időbontott fluoreszcencia spektrumokkal [123].
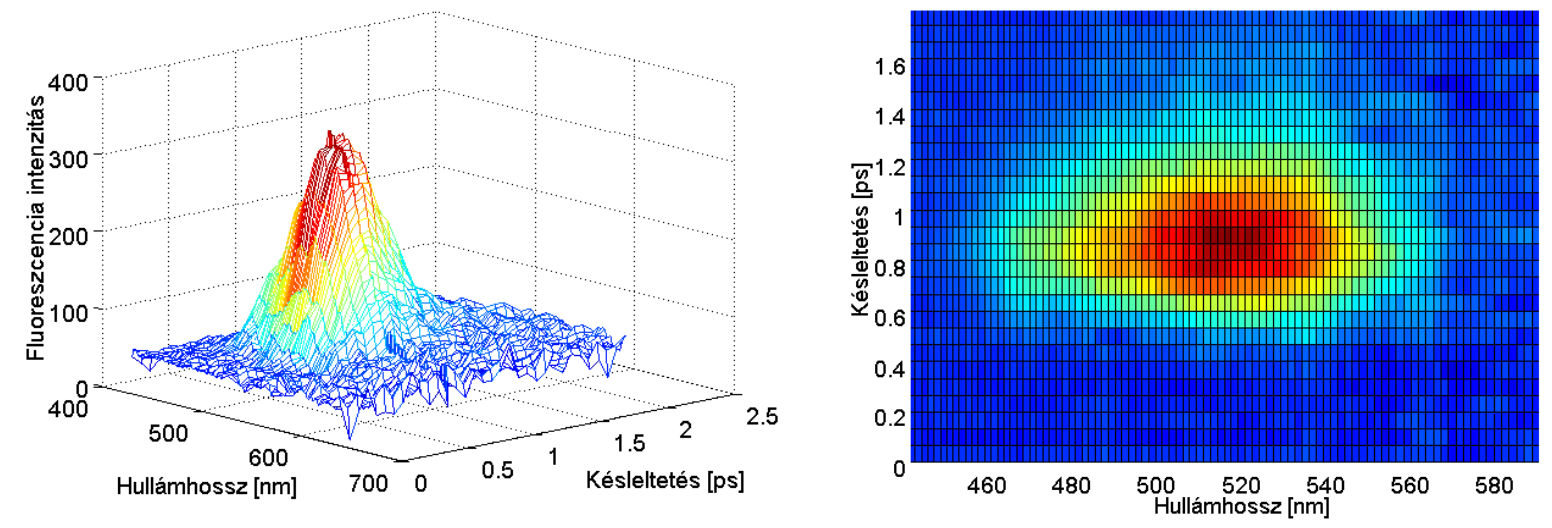

30. ábra - A Malachit green idő- és spektrálisan bontott fluoreszcenciája

A következő lépésben olyan lézerfestéket választottam - a Coumarin 153-at -, melynek fluoreszcenciájának lecsengése a nanoszekundumos nagyságrendbe esik, és jól ismert, egyszerü molekula [125]. Szobahőmérsékleten például etanolban a fluoreszcencia kvantumhatásfoka elérheti a $80 \%$-ot is, korábban gyakran használták lézeraktív anyagként rezonátorokban [126]. Ennek köszöntehően ígéretes jelölt a kísérleti beállításunk optimalizálására, hiszen szemmel jól látható a fluoreszcenciája. Így segítségével a frekvencia konverziós módszernél ellenőrizni lehet a késleltető egységünk precíz beállítását, vagyis a fluoreszcencia és kapuimpulzus térbeli átfedését a frekvenciaátalakító kristályban, a teljes időablakunkban.

Méréseim során először az iménti, Malachite Green festékkel jól beállított frekvencia konverziós eljárással mértem a kinetikákat a 100 fs - 1 ns időtartományban, majd ez követően a C153-mal.

A felkonvertálás esetében a késleltetési pontok 1 ns-ig logaritmikus skálán egyenletesen helyezkedtek el. A zajcsökkentés érdekében az így nyert adatokon az SVD módszerrel szürést hajtottam végre. Az így nyert Coumarin 153 időbontott fluoreszcencia spektrumát a 31. ábra mutatja. Az ábrán külön ábrázoltam az első 5 ps (31.a ábra), majd az 1 ns tartomány (31.b ábra) spektrumait a jobb áttekinthetőség miatt. 

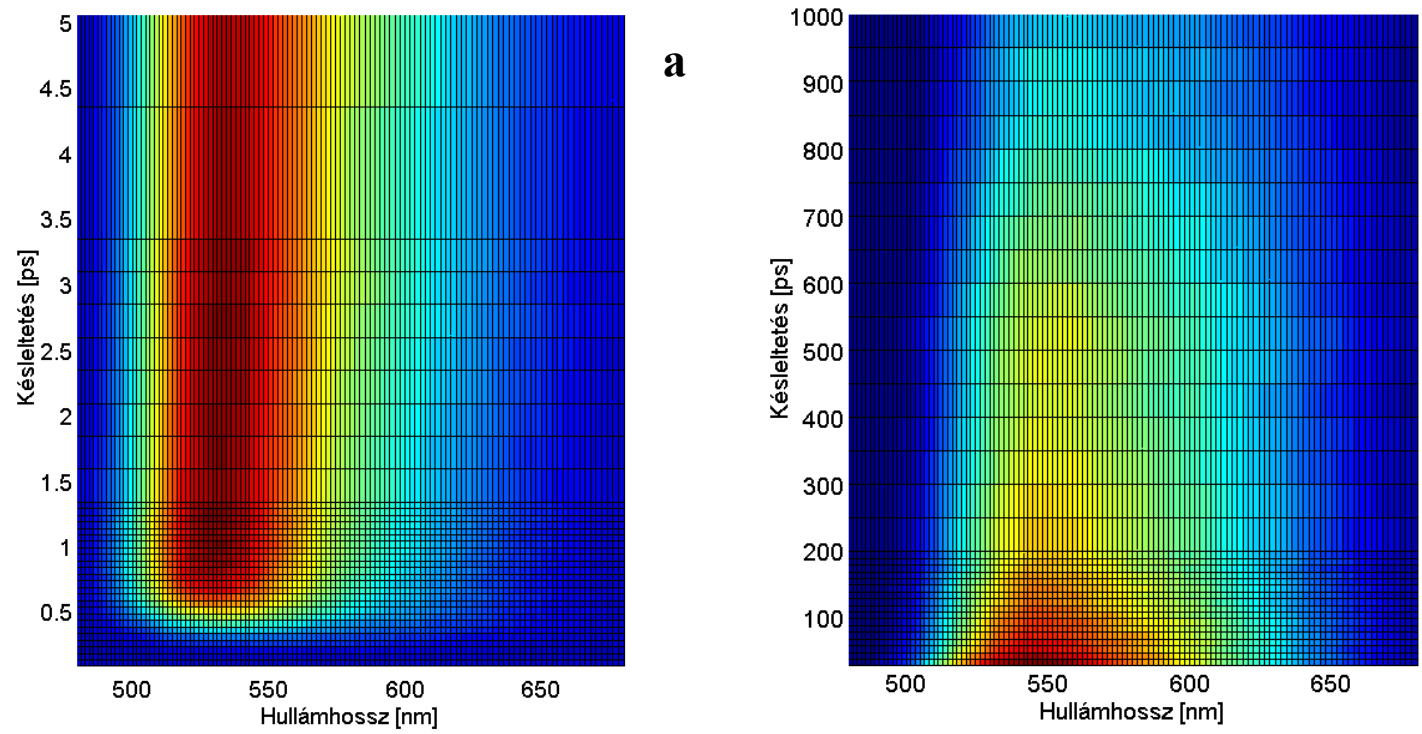

31. ábra - A C153 időbontott spektruma

Méréseink során azt tapasztaltuk, hogy a Coumarin fluoreszcencia spektrumának csúcsánál, 530 nm-en (32. a ábra), 1-2 ps késleltetésnél a fluoreszcencia eléri a maximális értéket. Így ennél a késleltetésnél, a spektrum csúcsánál (32. b ábra) optimális a fluoreszcenciát mérő berendezésünk beállítása. A mérések során a spektrum csúcsintenzitása 2700 fotonbeütés (count) körüli értéket ért el 1.5 ps késleltetésnél 2 darab UG11-es szürő használatával a monokromátor rése előtt. A továbbiakban minden egyes mérés előtt erre a spektrális és időbeli pontra optimalizáltam a fluoreszcencia intenzitásának beállítását mind a minta $2 \mathrm{D}$ mozgatásával, mind pedig a BBO kristály foragásával. Optimalizálás közben a BBO mögött elhelyezett kamerával néztem a fluoreszcencia és kapuimpulzus térbeli átfedését (a nagy kvantumhatásfok miatt szemmel látható a fluoreszcencia Coumarin esetében, míg a FAD-os mérések során nem), majd ezt követően a 317 nm-es összegfrekvencia intenzitás maximális értékére optimalizáltam, hogy a 1.5 ps késleltetésnél elérjük a 2700-as beütés értéket.
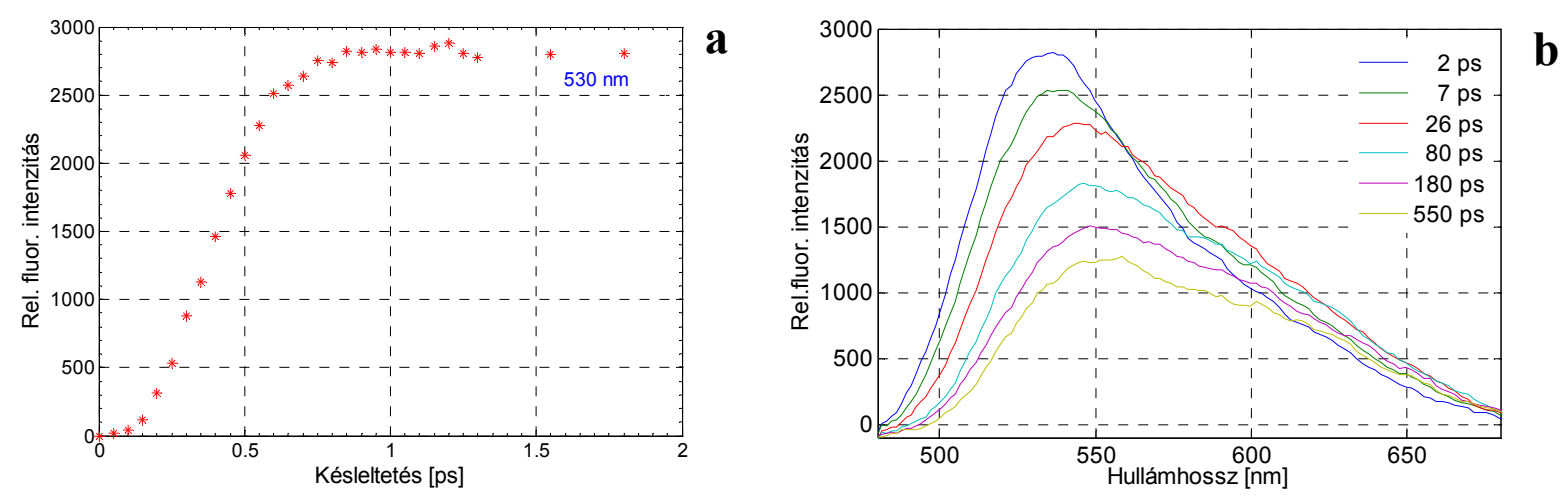

32. ábra - (a) A Coumarin 153 kinetikája 530 nm-en; (b) és spektrumának időfejlődése 
Ezt követően beállítottam a második parabolatükröt követően (26. ábrán látható módon) a csapótükör behelyezésével a fényutat a TCSPC elrendezéshez is a C153-mal, majd a monokromátor résére való leképezést. A gerjesztő impulzust (400 nm-es nyaláb beszóródását) alulvágó szürővel (FLG430) elimináltam. Majd a fluoreszcencia spektrum maximumára optimalizáltam: az egyfoton számláló detektor 3D mozgatásával a monokromátor kimeneténél. Végül ebben az elrendezésben megmértem a gerjesztő impulzussal a rendszer átviteli függvényét, majd a Coumarin 153 fluoreszcencia kinetikáit 10 nm-es lépésközökkel (33. ábra).

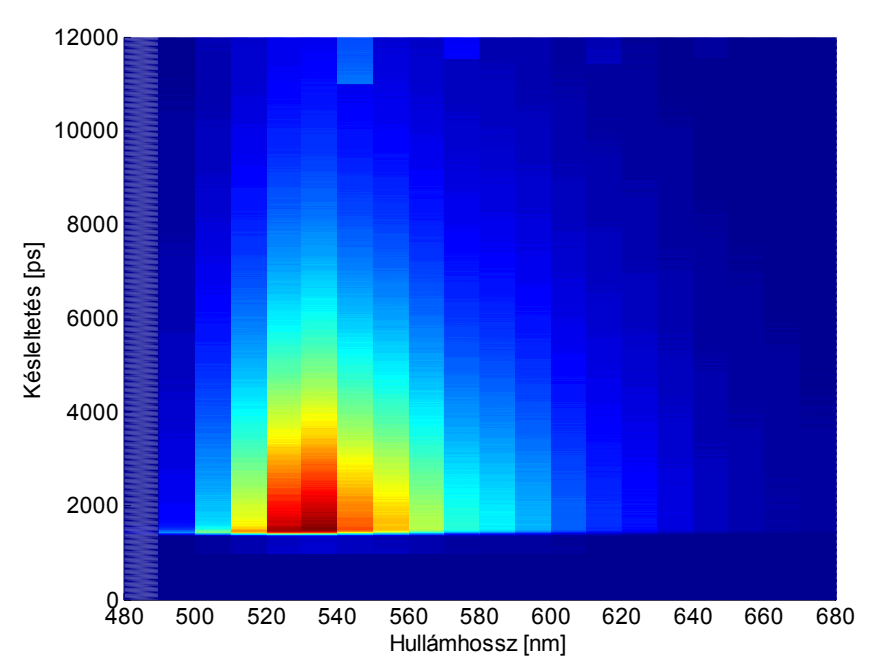

33. ábra - A C153 időbontott spektruma a TCSPC elrendezéssel mérve

\subsubsection{A BPDN ANALÍZIS (KIÉRTÉKELÉSI ALGORITMUS)}

Az időbontott fluoreszcencia spektroszkópia és a FLIM nagyon hatékony módszerek a fluoreszkáló kromofórok mikrokörnyezetének jellemzésére különböző rendszerek esetében [63, 96], és a fluoreszcencia lecsengési kinetikák általában jól jellemezhetőek exponenciális eloszlással (részletesen a 2.2.4.1. fejezetben mutattam be). A gyakorlatban viszont problémát jelenthet, hogy a mérendő minták általában heterogének, ami több exponenciális megjelenését eredményezheti. Továbbá a kinetika a spektrum különböző tartományaiban is eltérő lehet, például az oldószer szolvatációs válaszának következtében. A multiexponenciális illesztés viszont közismerten rosszul meghatározott (ill posed) probléma [127, 128], az illesztés gyakran kerül lokális minimumokba, a végeredmény pedig igen érzékeny a zajokra, ráadásul általában az exponenciálisok száma sem ismert előre.

Alternatív eljárásnak kínálkozik, hogy néhány diszkrét időállandó $(\tau)$ és a hozzájuk tartozó amplitúdó keresése helyett egy széles időállandó-tartományban sürün elhelyezkedő, $n$ 
elemü $\tau_{j}$ halmazhoz keressük azokat az $x_{j}$ amplitúdókat, amelyek a legjobb illeszkedést biztosítják [129]. Nyilvánvalóan a legtöbb $x_{j}$ értékre zérust, vagy legalábbis igen kis $x_{j}$ értéket várunk. Zajmentes esetben a probléma matematikailag az

$$
y=A x
$$

egyenletrendszer megoldását jelenti, ahol $y_{i} \quad(i=1 \ldots m)$ a $t_{i}$ időpontban egy adott hullámhosszon mért fluoreszcencia intenzitást jelöli,

$$
A_{i j}=\exp \left(-t_{i} / \tau_{j}\right)
$$

és az egyenletrendszer alulhatározott, azaz $n>m$. Zaj esetén ennek megfelelően az

$$
\|A x-y\|_{2} \equiv \sqrt{\sum_{i=1}^{m}\left(\sum_{j=1}^{n} A_{i j} x_{j}-y_{i}\right)^{2}}
$$

$L^{2}$ norma minimumát kell meghatároznunk [127, 128, 130]. Az alulhatározottság megengedi, hogy az $x_{i}$ értékekre valamely regularizáló feltételt szabjunk. Esetünkben a kívánt cél az, hogy $x$ nem zérus értékü elemeinek számát (a gyakran $L^{0}$ normának nevezett értéket) minimalizáljuk. Ehhez hasonló problémák számos más területen is felmerülnek, és az utóbbi években 'compressed sensing' gyüjtőnéven intenzív kutatás tárgyát képezik [131]. A témakör egyik legkiemelkedőbb eredménye szerint bizonyos feltételek mellett az $L^{0}$ normával nyert regularizált megoldás numerikusan jól közelíthető az

$$
\|x\|_{1} \equiv \sum_{i=1}^{n}\left|x_{i}\right|
$$

$L^{1}$ normával végzett regularizációval, ami számítástechnikailag az előzőnél lényegesen egyszerübb feladat [132]. Zajmentes esetben megoldandó tehát az úgynevezett 'Basis Pursuit' probléma

$$
\min :\|x\|_{1} \quad A x=y,
$$

zaj esetén pedig az ennek megfelelö 'Basis Pursuit Denoising' (BPDN) probléma

$$
\min :\|A x-y\|_{2}^{2}+\lambda\|x\|_{1},
$$

ahol $\lambda$ a regularizáció mértékét meghatározó paraméter [133]. 
Groma Géza a fentiekben meghatározott problémák megoldására először különböző zajszinttel szintetikusan generált adatokon tesztelte a BPDN-eljárást. A tényleges mérési adatok kiértékelésére a l1_ls programot használtuk (a 'Compressed Sensing Resources' weboldalon elérhető programcsomag [134]), a különböző hullámhosszakon mért adatokra egyenként alkalmazva. A $\lambda$, regularizációs paraméter értékét úgy állítottuk be, hogy az illeszkedés a lehető legjobb legyen, de a lecsengési szakaszban nem elhanyagolható értékü negatív amplitúdók ne jelenjenek meg. Az $m=51$ számú $t_{i}$ mérési időpont logaritmikusan egyenletesen skálán helyezkedett el (ld. bővebben az 5.3.3. fejezetben). 


\subsection{AZ ABSZORPCIÓKINETIKA MÉRÉSHEZ ALKALMAZOTT PUMPA-PRÓBA RENDSZER}

\subsubsection{A MINTA ELÖKÉSZÍTÉSE ÉS TULAJDONSÁGAI}

A méréseknél mindvégig 3.0×10 $0^{-4} \mathrm{M}$ koncentrációjú NADH (Sigma-Aldrich) mintákat használtam, amelyeket minden mérés előtt frissen készítettem. A vizes oldatokban pufferként 0.1 M PIPES-t alkalmaztam $\mathrm{pH}=7.0$ értéken, mert az irodalom alapján a NADH stabilitása e puffer esetén optimálisabb [135]. A minták stabilitását abszorpciós spektrumuk alapján ellenőriztem. A nyitott és zárt konformációs állapotban lévő NADH molekulák száma metanol hozzáadásával szabályozható [59]. Ennek megfelelően 0, 50, 70 és $80 \%$ metanol koncentrációk esetében vizsgáltam a kinetikákat.

\subsubsection{A KÍSÉRLETI ELRENDEZÉS}

A femtoszekundumos abszorpciókinetikai méréseket standard pumpa-próba módszerrel végeztem a strasbourgi IPCMS DON csoportjánál. A mérések során az adenin csoportot gerjesztettem $266 \mathrm{~nm}$ központi hullámhosszú pumpa impulzussal, amelyet az erősített titánzafír rendszer ( $5 \mathrm{kHz}, 40$ fs, $500 \mu \mathrm{J})$ impulzusainak harmadik harmonikusának elöállításával biztosítottam. A pumpa átlagteljesítménye $640 \mu \mathrm{W}$, a minta fókuszában a nyalábnyak mérete pedig $118 \mu \mathrm{m}$ volt. A próba nyalábot kalcium-fluorid tömbben való fehér fény kontinuum (WLC) keltéssel állítottam elő a 330-630 nm spektrális tartományban (33. ábra). Ennek nyalábnyak mérete a mintán $36 \mu \mathrm{m}$ volt. Ahogy a 33. ábrán is látható, az UV-látható tartományon a 4a, KG1 és OD 0.7-es jelzésű szürők esetén megfelelően széles a WLC spektrum, így ezen szürők használatával vizsgálni tudjuk mind a nikotinamid csoport gerjesztett állapoti abszorpciójának (350-400 nm), mind pedig a stimulált emissziójának (450$550 \mathrm{~nm}$ ) időbeli fejlődését. 


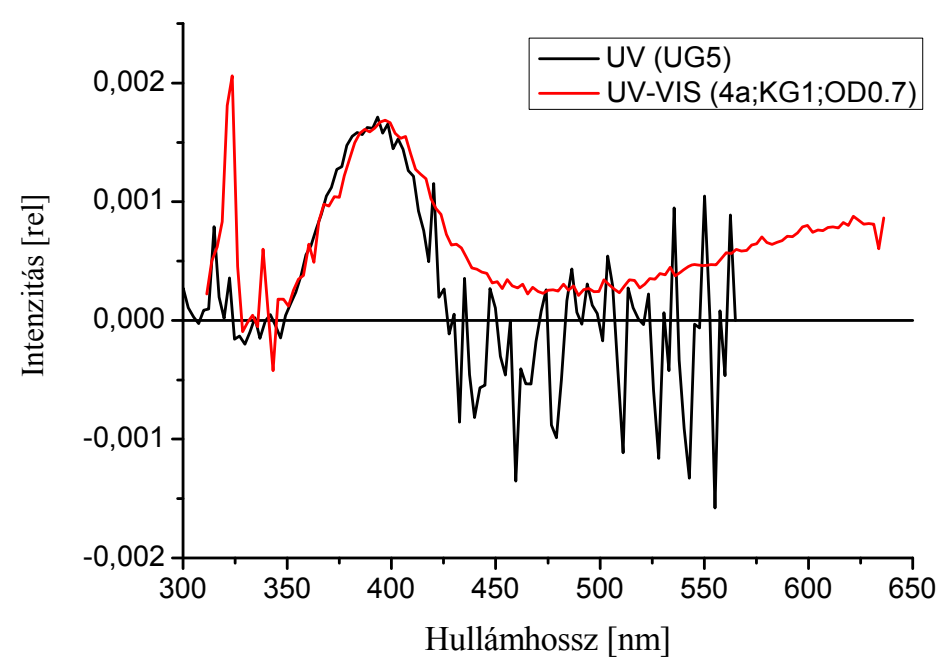

34. ábra - A próba impulzus spektruma különböző szürők alkalmazásával

A kísérleti összeállítást a 35. ábrán mutatom be. A minta előtt a kontinuumot 2 részre osztottam, egyik volt a próba nyaláb, másik pedig a méréseim során referenciának szolgált az abszorpció-változás pontos meghatározásához. A minta után a próba és referencia-nyalábot monokromátorba vezettem, és hütött CCD kamerával detektáltam a spektrumokat. A kinetika mérések időbeli felbontása a hullámhossztól függően 50-100 fs volt. Mintatartónak egy 0.5 $\mathrm{mm}$ átmérőjü négyzetes kvarc cellát használtam, melyben a folyadékmintákat egy perisztaltikus pumpa segítségével áramoltattam.

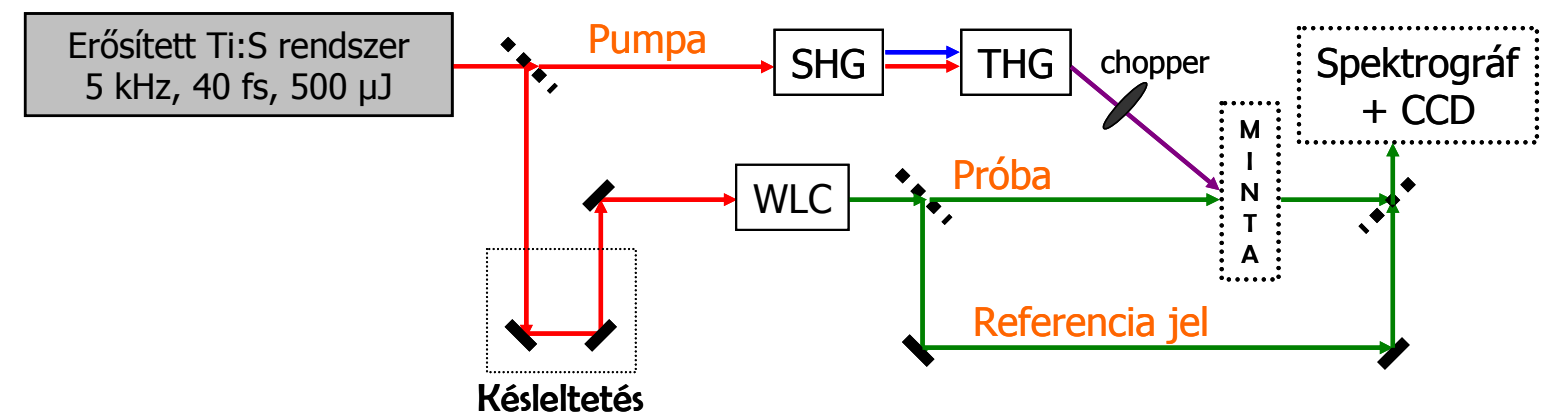

35. ábra - A pumpa-próba mérés elrendezése (SHG: másodharmonikus keltés, 400 nm; THG: harmadik harmonikus keltés, 266 nm; WLC: fehérfény kontinuum, 330-630 nm) 


\subsubsection{ADATKIÉRTÉKELÉS A TRANZIENS ABSZORPCIÓS SPEKTROSZKÓPIÁBAN}

Az időfelbontásos fluoreszcenciához hasonlóan, a tranziens abszorpciós adatok kiértékelése során a mért $\Delta \mathrm{A}(\lambda, \mathrm{t})$ 2D mátrix elemzésével célunk az, hogy a gerjesztett állapot(ok) élettartamát és amlitudóinak spektrális eloszlását meghatározzuk, ezáltal információhoz jussunk a molekulában lezajló fotofizikai, fotokémiai változásokról. Ehhez azonban ebben az esetben is néhány korrekciót és zajszürést kell elvégeznünk. Az alábbiakban röviden ismertetem a lényegesebbeket sorban:

1. Átviteli függvény, IRF

2. SVD zajszürés

3. Spektrális kalibráció

4. Csörpkorrekció

5. Oldószer válasza

6. Globális analízis

Az 1-2 lépés azonos az előző fejezetben ismertetett módszerekkel, a spektrális kalibrációt pedig a mérési program már magába foglalta.

\section{CSÖRPKORREKCIÓ}

Mivel a WLC nagy spekrális sávszélességgel rendelkezik, az anyagi diszperzió hatása, valamint a pumpálás hatására létrejövő kétfotonos abszorpció (two photon absorption, TPA) hatása is jelentős, ami azt eredményezi, hogy az oldószernél mért TPA jelnél a vörös komponens lemarad a kék komponensekhez képest. A 36. ábrán a WLC időbeli megnyúlását szemléltetem 80\% metanol-tartalmú PIPES puffer esetén mért TPA spektrummal. Jól látható, hogy a spektrum piros oldala időben lemarad, azaz erösen csörpölt a WLC impulzus. Az alábbiakban röviden bemutatom az általam alkalmazott csörpkorrekciót.

A korrekciót Matlab-ben végeztem. Mivel több megoldás is alkalmazható e korrekció elvégzésére, én azt mutatom be, amellyel korrigáltam a mérési adatsoraimat. Kiszámoltam, hogy a WLC terjedése közben a kalcium-fluorid tömb $\left(\mathrm{CaF}_{2}\right) 0.15 \mathrm{~mm}$ vastagsága, és a kvarc küvetta $\left(\mathrm{SiO}_{2}\right)$ falainak összesen $0.2 \mathrm{~mm}$ vastagsága összesen mekkora csörpöt okoz, majd a késleltetések függvényében kapott diszperziótól mentesítettem adatsoraimat. 


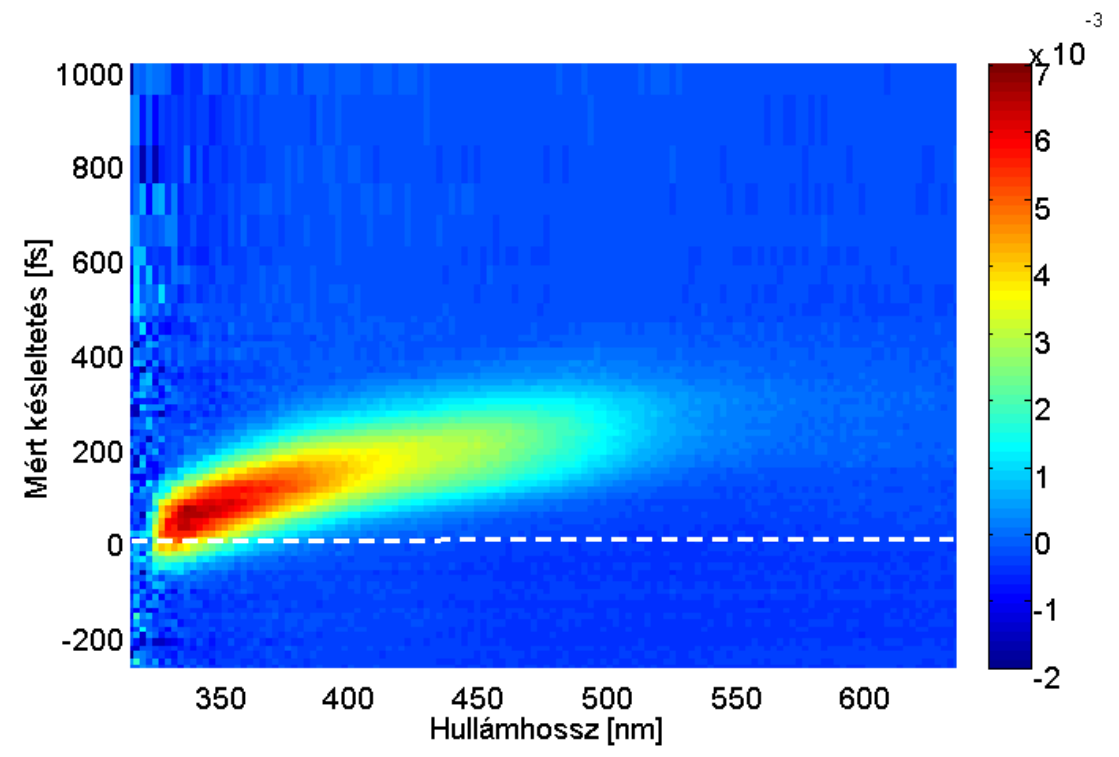

36. ábra - A PIPES puffer időbontott spektruma $80 \%$ metanol jelenléte esetén

A csörpkorrekciónál a $\mathrm{CaF}_{2}$ és a $\mathrm{SiO}_{2}$ anyagok Sellmeier-egyenleteit használtam alapul [136]:

$$
\mathrm{n}_{\mathrm{SiO}_{2}}=\sqrt{1+\frac{\left(\lambda^{2} \cdot \mathrm{c}_{1}\right)}{\left(\lambda^{2}-\mathrm{c}_{2}{ }^{2}\right)}+\frac{\left(\lambda^{2} \cdot \mathrm{c}_{3}\right)}{\left(\lambda^{2}-\mathrm{c}_{4}{ }^{2}\right)}+\frac{\left(\lambda^{2} \cdot \mathrm{c}_{5}\right)}{\left(\lambda^{2}-\mathrm{c}_{6}{ }^{2}\right)}}
$$

valamint

$$
\mathrm{n}_{\mathrm{CaF}_{2}}=\sqrt{1+\frac{\left(\lambda^{2} \cdot \mathrm{k}_{1}\right)}{\left(\lambda^{2}-\mathrm{k}_{2}^{2}\right)}+\frac{\left(\lambda^{2} \cdot \mathrm{k}_{3}\right)}{\left(\lambda^{2}-\mathrm{k}_{4}{ }^{2}\right)}+\frac{\left(\lambda^{2} \cdot \mathrm{k}_{5}\right)}{\left(\lambda^{2}-\mathrm{k}_{6}{ }^{2}\right)}}
$$

Az egyenletekben $\lambda \mu$ m-ben értendő, $c_{n}$ és $k_{n}$ konstansok $(n=1 \ldots 6)$ pedig a két anyag Sellmeier-együtthatói, amelyeket a 3. táblázatban adok meg [137, 138].

\begin{tabular}{ccc}
\hline $\mathrm{n}$, index & $\mathrm{c}_{\mathrm{n}}$ & $\mathrm{k}_{\mathrm{n}}$ \\
\hline 1 & 0.6961663 & 0.5675888 \\
2 & 0.0684043 & 0.050263605 \\
3 & 0.4079426 & 0.4710914 \\
4 & 0.1162414 & 0.1003909 \\
5 & 0.8974794 & 3.8484723 \\
6 & 9.896161 & 34.649040 \\
\hline
\end{tabular}

3. táblázat - $\mathrm{A} \mathrm{SiO}_{2}\left(\mathrm{c}_{\mathrm{n}}\right)$ és a $\mathrm{CaF}_{2}\left(\mathrm{k}_{\mathrm{n}}\right)$ Sellmeier-koefficiensek értékei 
Figyelembe véve tehát a WLC terjedése közben a két anyag törésmutatójából származó fázissebességeket, valamint egy kezdeti 'offset'-et, amely a $\mathrm{t}=0$ időpont (a pumpa és próba impulzusok tökéletes időbeli átfedése, ahol a CCF maximális) pontatlanságából adódik, a végső polinom

$$
\mathrm{P}(\lambda)=\frac{\mathrm{n}_{\mathrm{SiO}_{2}} \cdot \mathrm{d}_{\mathrm{Si}_{2}}}{\mathrm{c}_{0}}+\frac{\mathrm{n}_{\mathrm{CaF}_{2}} \cdot \mathrm{d}_{\mathrm{CaF}_{2}}}{\mathrm{c}_{0}}+\text { offset }
$$

alakú, ahol $\mathrm{c}_{0}$ a fénysebesség vákuumban, $\mathrm{d}$ az anyagban megtett úthossz, $\mathrm{n}$ pedig az adott anyag törésmutatója.

Mivel a törésmutató felírható $\left(\mathrm{n}_{0}+\delta \mathrm{n}\right)$ alakban, ahol az $\mathrm{n}_{0}$ konstans, így számolásaimnál csak az adott hullámhossztartományhoz tartozó diszperziót $(\delta n)$ vettem figyelembe. Így csak egy egyszerü polinomillesztést hajtottam végre (4.14) alapján kicsiny offszet értékekkel: $t_{0}$ értékét a kísérlet alapján (IRF-ből) le tudjuk rögzíteni. A korrigált időbontott spektrumot a Tudományos eredményeim című fejezetben mutatom be (70. ábra).

\section{OLDÓSZER VÁLASZA ÉS LEVONÁSA}

Alacsony pumpaintenzitásoknál az oldószerünk válasza a TPA-s és keresztfázis-modulációs jeleket is tartalmazza, amelyektől mentesítenünk kell az adatsorainkat. A gyakorlatban az oldószerünk válaszát az alábbi módon, az $f$ faktor illesztésével szokás figyelembe venni (az illesztés jóságát a $\mathrm{t}=0$ érték korrekció utáni megtartása, valamint a $\mathrm{t}<0$ tartományon a háttérszint megtartása $(\Delta \mathrm{A}=0)$ jelenti):

$$
\Delta \mathrm{A}_{\mathrm{MINTA}}=\Delta \mathrm{A}_{\text {MINTA+OLDÓSZER, mért }}-\mathrm{f} \cdot \Delta \mathrm{A}_{\text {OLDÓSZER, mért }}
$$

Itt kihasználtuk azt az egyszerüsítő feltevést, hogy a mérések során a pumpa impulzus energiája nem változott. Ebben az esetben kimutatható [139], hogy az illesztési faktor a mintánk OD-jétől az alábbi módon függ:

$$
\mathrm{f}=\frac{1-10^{-\mathrm{OD}}}{2.3 \cdot \mathrm{OD}}
$$

Esetünkben a minták 0.3-0.4 OD-jának megfelelően $f=0.65-0.72$ értékek közé esik, amelyet illesztéssel határoztam meg minden egyes metanol koncentrációnál. 


\section{GLOBÁL ANALÍZIS}

A globális analízis módszere azon a feltevésen alapul, hogy a lecsengési idők függetlenek a hullámhosszaktól. Ezzel a feltevéssel egyidejűleg illeszthetünk az 1-5. korrekciók elvégzése után kapott néhány karakterisztikus tranziensre (például abszorpciós és emissziós maximumoknál) exponenciálisok összegét, és kiszámolhatjuk az egyes amplitudókat és időállandókat. Majd mindezt kiterjesztjük a teljes spektrális tartományra úgy, hogy a kapott időállandókat lerögzítjük, és csak az amplitudókat illesztjük minden egyes hullámhosszon. Egy adott időállandóhoz tartozó amplitudó hullámhosszfüggését amplitudó spektrumnak nevezzük (DAS, decay-associated spectrum). Tranziens abszorpciós mérésnél a pozitív DAS abszorpció, a negatív DAS pedig az SE lecsengését jelenti. A gyakorlatban tehát a $\Delta \mathrm{A}(\mathrm{t}, \lambda)$ adathalmazunk

$$
\Delta \mathrm{A}(\lambda, \mathrm{t})=\sum_{\mathrm{i}=1}^{\mathrm{M}}\left(\mathrm{e}^{-\mathrm{k}_{\mathrm{i}} \mathrm{t}} \otimes \operatorname{IRF}(\mathrm{t})\right) \cdot \operatorname{DAS}_{\mathrm{i}}(\lambda)
$$

alakú, amiből az IRF és az exponensek konvolúciójából megkaphatjuk a DAS( $\lambda$ )-okat. 


\section{TUDOMÁNYOS EREDMÉNYEK}

\subsection{A bR SZUSZPENZIÓ TÖRÉSMUTATÓJÁNAK MÉRÉSE}

Méréseim során először a TRIS puffer törésmutatóját, majd a bR szuszpenziók törésmutatóját határoztam meg $0-76 \mu \mathrm{M}$ koncentráció-tartományon. A minimális deviáció szögét a normális diszperziós tartományon 10 nanométerenként mértem, az abszorpciós tartományon viszont - ahol a bR minta anomális diszperziót mutat (500-600 nm) - 5 nanométerenként. Minden egyes mért hullámhosszon három egymást követő mérést végeztem, így a szögmérés összegzett standard deviációja $0.0017^{\circ}$ értéknél kisebb volt [111]. A minimális deviáció szögének ismeretéböl a (4.3) egyenlet alapján meghatároztam a törésmutató értékeket, ahol a levegö diszperzióját az aktuális laboratóriumi állapotra nagy pontossággal kiszámoltam a hőmérséklet- és nyomásfüggő Sellmeier-egyenletből [140].

A mérés hibáját végső soron a szögmérés, ill. maga a törésmutató értéke befolyásolja. A szögmérés hibája az üreges prizma gyártási hibáiból és a goniométer pontosságából adódik, esetünkben ez 0.09 szögperc volt.

A törésmutató meghatározásakor a hibaterjedés az üreges prizma, ill. a mért minimális deviáció szögétől a következőképpen függ:

$$
\mathrm{dn}=\left|\frac{\partial \mathrm{n}(\delta, \varphi)}{\partial \delta}\right| \mathrm{d} \delta+\left|\frac{\partial \mathrm{n}(\delta, \varphi)}{\partial \varphi}\right| \mathrm{d} \varphi,
$$

Ebből a törésmutató-mérés teljes hibája esetünkben 0.0004-től (a közeli infravörösben) 0.0003-ig (a közeli ultraibolyában) változott.

\subsubsection{A TRIS PUFFER TÖRÉSMUTATÓJA}

A 37. ábrán a minimális deviáció szögének méréséböl és a levegő pontos törésmutatójából meghatározott törésmutató hullámhosszfüggése látható a TRIS $(10 \mathrm{mM}, \mathrm{pH}=7.0)$ puffer esetén. A levegő törésmutatója hatásának demonstrációja céljából a 37. ábrán szemléltetem, hogy az $\mathrm{n}_{\text {air }}=1$ közelítésnél mennyire eltérö értékeket kapunk a pontos értékekhez képest. 


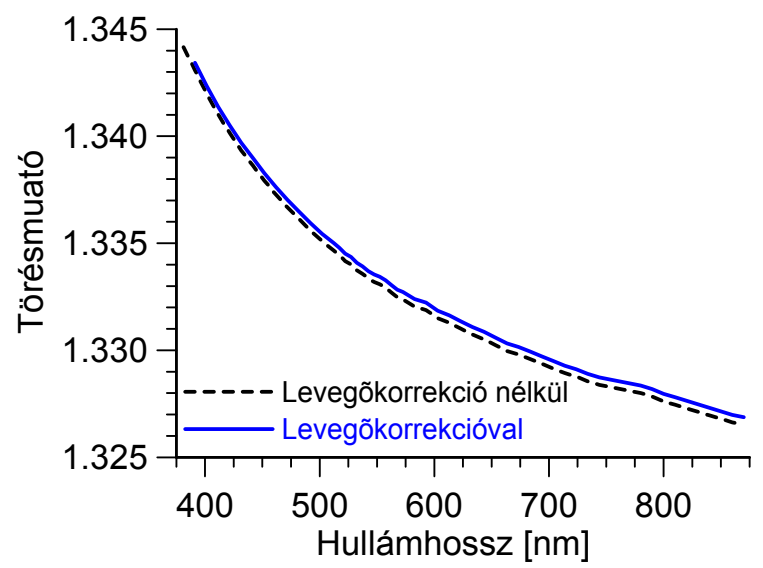

37. ábra - TRIS puffer törésmutatója levegökorrekcióval (kék) és korrekció nélkül (fekete)

Egy anyag törésmutatójának könnyebb kezelése érdekében a mért adatokra diszperziós egyenleteket szokás illeszteni. A létező sokféle képlet közül két okból is a Sellmeier-típusú egyenletet választottam. Először is, ez az egyetlen szemi-empirikus diszperziós egyenlet, azaz az alapvető formája levezethető az abszorpció és diszperzió Lorentz-féle elméletéből. Másodszor, mivel mind a TRIS, mind a bR minta relatíve sok vizet tartalmaz, ezért törésmutatójuk várhatóan közel lesz a desztillált víz törésmutatójához, ami nagyon pontosan illeszthető a Sellmeier-típusú egyenlettel az ultraibolyától a közeli infravörösig [141]. A TRIS ugyan a kémiában, biológiában és biofotonikában népszerü és elterjedt puffer, egyéb, a kémiában gyakran használt oldószerekkel ellentétben [142] optikai tulajdonságai - mint például törésmutatója és diszperziója - nem ismertek.

A TRIS puffer esetén a Sellmeier-egyenletet a (2.10) alakban írható fel. Az egyenletet a lehető legegyszerübb formájában használva először egy egytagú $(i=1)$ kifejezést illesztettem a feltüntetett együtthatókkal (4. táblázat).

\begin{tabular}{lcccc}
\hline TRIS (10mM, pH 7.0) & $\mathrm{A}_{1}\left(10^{5}\right)$ & $\mathrm{A}_{2}\left(10^{9}\right)$ & $\lambda_{1}[\mathrm{~nm}]$ & $\lambda_{2}[\mathrm{~nm}]$ \\
\hline Egytagú Sellmeier & 7.363698414 & - & 101.0293566 & - \\
Kéttagú Sellmeier & 7.757363056 & 1.17425171286 & 98.6571625 & 1040.2402896 \\
\hline
\end{tabular}

4. táblázat - A Sellmeier-egyenlet együtthatói normál légköri nyomáson és $22{ }^{\circ} \mathrm{C}$ hömérsékleten TRIS pufferre 
Ebben az esetben az illesztés eltérése a mért adatoktól (38. ábra) elfogadhatatlanul nagy, azonban egy kéttagú, azaz négyparaméteres Sellmeier-formula már nagyon jól illeszkedik. Utóbbi esetben a mért és illesztett értékek közti eltérés kisebb, mint $1 \cdot 10^{-4}$, ami jóval a $4 \cdot 10^{-4}$ es mérési pontosságon belül van.

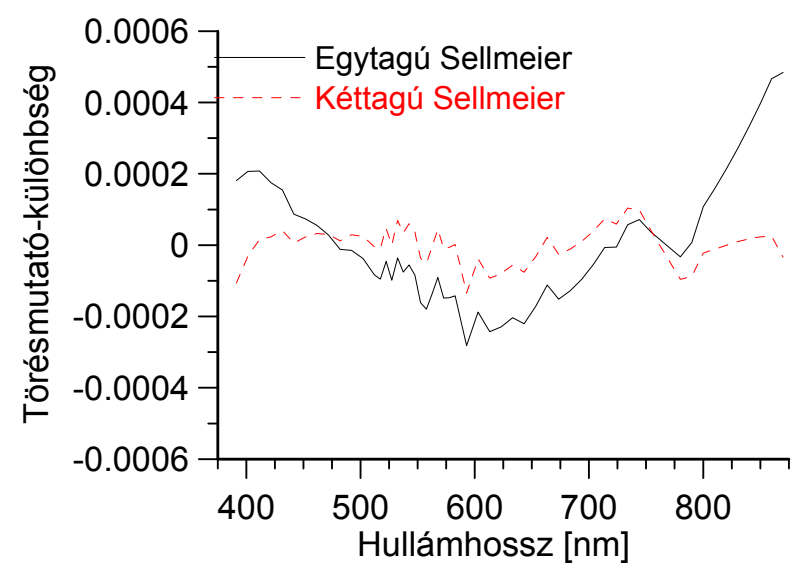

38. ábra - A mért és illesztett törésmutató-értékek eltérése TRIS puffernél

\subsubsection{A bR SZUSZPENZIÓ KONCENTRÁCIÓFÜGGŐ TÖRÉSMUTATÓJA}

A bR törésmutatója meghatározásának második lépéseként 10, különböző mértékben higított bR szuszpenzió törésmutatóját mértem meg. A jobb láthatóság kedvéért a 39. ábrán csak 4 koncentrációnál ábrázoltam a 390 és $880 \mathrm{~nm}$ között mért törésmutató-értékeket. Amint látható, ilyen alacsony koncentráció esetén az oldatok normális diszperziót mutatnak az egész hullámhossz-tartományon, a bR 560 nm körüli anomális diszperziója nem figyelhető meg.

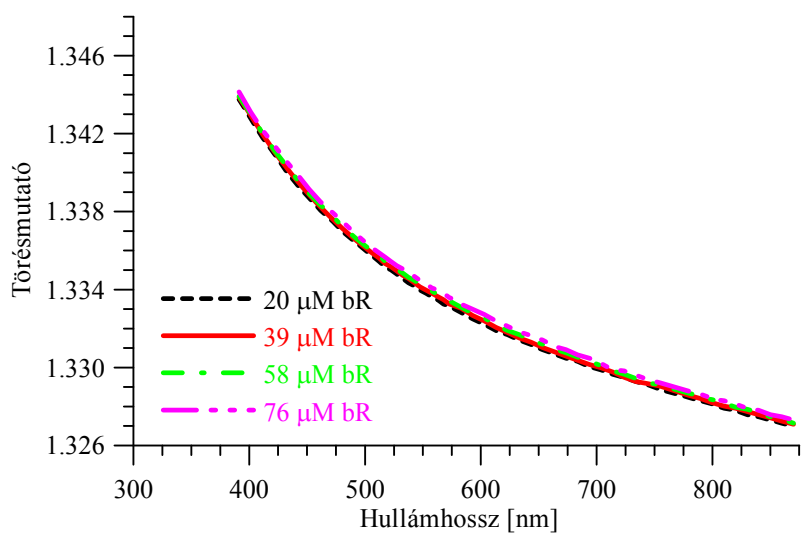

39. ábra - Különböző koncentrációjú bR oldatok mért törésmutatója 
A 40. ábrán két hullámhosszon $(562,800 \mathrm{~nm})$ mért törésmutató-értékek láthatóak az összes mért koncentráció esetén. A koncentráció-függés teljes hullámhossz-tartományra vonatkoztatott hasonlósága ellenére a kiemelt hullámhosszakat az alapján választottam, hogy az egyik a sötétadaptált bR abszorpciós maximuma (562 nm), míg a másiknál (800 nm) egyáltalán nem várható abszorpció. Mindkét esetben, ahogyan az összes többi hullámhosszon is, a mért törésmutató-értékek egyenesen arányosak a bR oldat koncentrációjával.

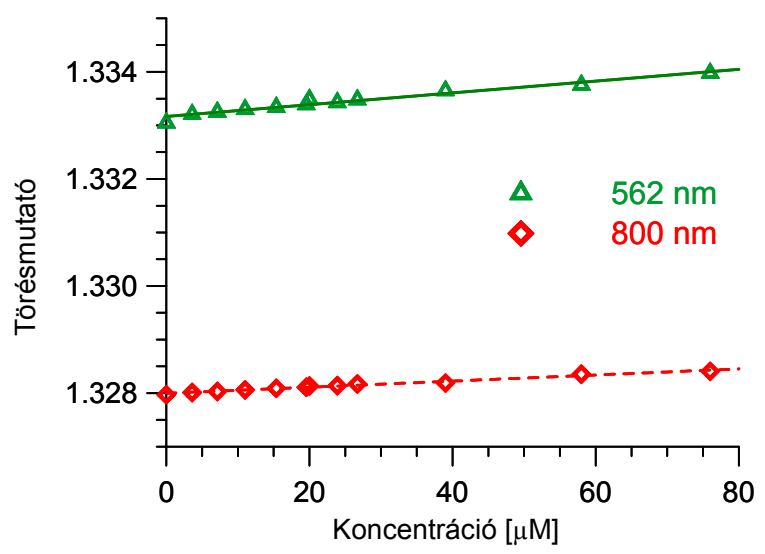

40. ábra - A bR oldatok mért törésmutató-értékei a koncentráció függvényében két különbözö hullámhosszon (562nm: a bR fö abszorpciós vonala; $800 \mathrm{~nm}$ : abszorpció-mentes).

A teljes méréssorozatot megismételtem, kezdve egy friss, fagyasztott bR minta felolvasztásával és higításával, a 4. fejezetben leírt módon. A mért törésmutatók kiválóan egyeztek az előző méréssorozat eredményeivel.

A polarizáció hatásának vizsgálatához a lézerfény polarizációját egy $\lambda / 2$ lemez segítségével forgattam. Alacsony koncentrációkon nem tapasztalható törésmutató-különbség a két ortogonális polarizáció esetén. Csak az általunk használt legmagasabb koncentrációnál (76 $\mu \mathrm{M})$ tapasztaltunk eltérést, az s-polarizált fényre kapott értékek kicsivel kisebbek voltak a ppolarizáltra kapottaknál. A mért eltérés a mérési hiba nagyságrendjében volt, ez alátámasztja, hogy szuszpenzióban nincs kitüntetett irány, így nem várható polarizációs hatás. 


\subsubsection{AZ IZOLÁLT BÍBOR MEMBRÁNOK TÖRÉSMUTATÓJA}

Az előzőekben leírtak után kiszámoltam a bR saját - azaz az izolált bíbor membránok törésmutatóját a különböző mértékben higított bR szuszpenziók mért törésmutatójának értékéből, és az előzőekben meghatározott TRIS puffer négytagú Sellmeier-egyenletéből ((2.10) egyenlet, $i=2)$. A törésmutató-értékeket a Schwers-egyenletböl (4.1) is, valamint a lineáris közelítésböl (4.2) is meghatároztam a teljes spektrális tartományon, a kapott eredményeket a 41-42. ábrák mutatják.

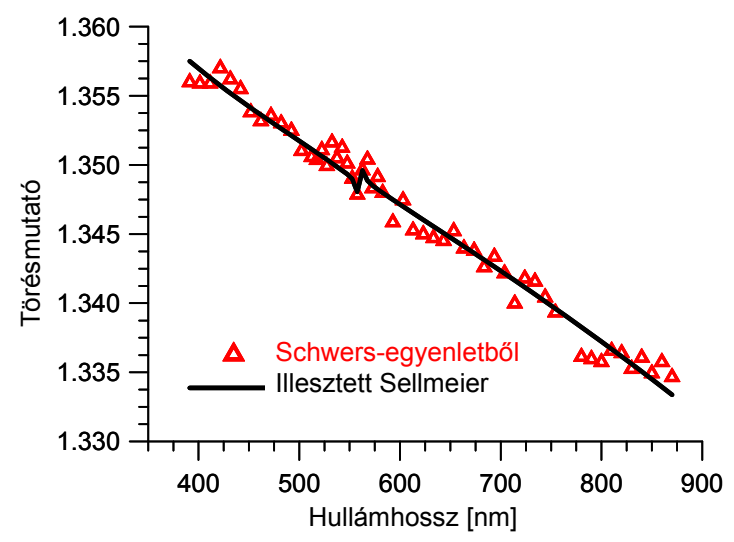

41. ábra - A bR saját törésmutatója a Schwers- és a Sellmeier-egyenletből

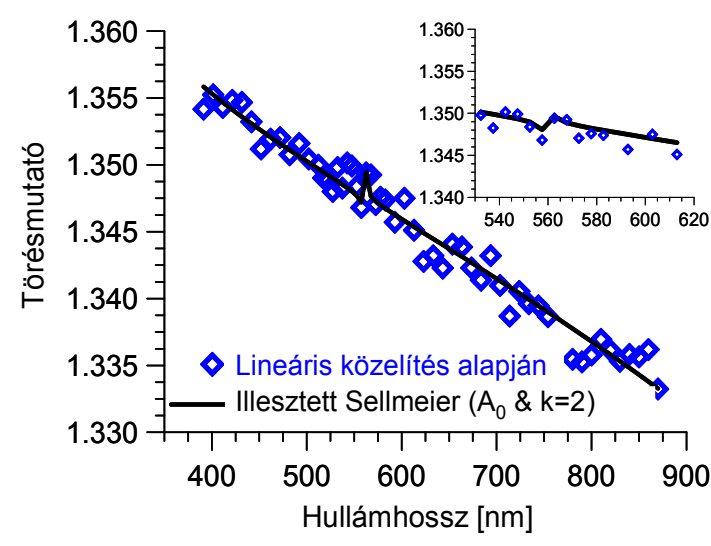

42. ábra - A lineáris közelítésböl és az illesztett Sellmeier-egyenletből számolt bR-törésmutató

Miután a törésmutatót az egész látható - közeli infravörös tartományon megmértem, egy, a mérési adatokra jól illeszkedő diszperziós egyenletet kellett keresnem. Mivel a sötétadaptált bR-nek 560 nm körül abszorpciós maximuma van, a hagyományos Sellmeiertípusú képlet (mint (2.10)) nem alkalmazható közvetlenül. Ezért a különböző képletek közül a kéttagú Sellmeier-egyenlet szemi-empirikus változatát választottam a kövekező formában:

$$
\mathrm{n}(\lambda)^{2}-1=\frac{\mathrm{A}_{0}}{1+\left(\lambda^{-2}-\lambda_{0}^{-2}\right)}+\sum_{\mathrm{i}=1}^{2} \frac{\mathrm{A}_{\mathrm{i}}}{\lambda^{-2}-\lambda_{\mathrm{i}}^{-2}}
$$

ahol $A_{0}$ és $\lambda_{0}$ az abszorpció erősségére és helyére vonatkozó paraméterek. Az 5. táblázat tartalmazza mindkét esetre az (5.2) egyenlet illesztéséből kapott paramétereket. Az illesztési eljárás mindkét esetben jól adta vissza a $\lambda_{0}$ abszorpciós sáv helyét, a mért és illesztett értékek közti eltérés kisebb volt, mint 0.001 (43. ábra). Amint látható, esetünkben gyakorlatilag nincs különbség a Schwers-formula és a lineáris közelítés pontossága közt. 


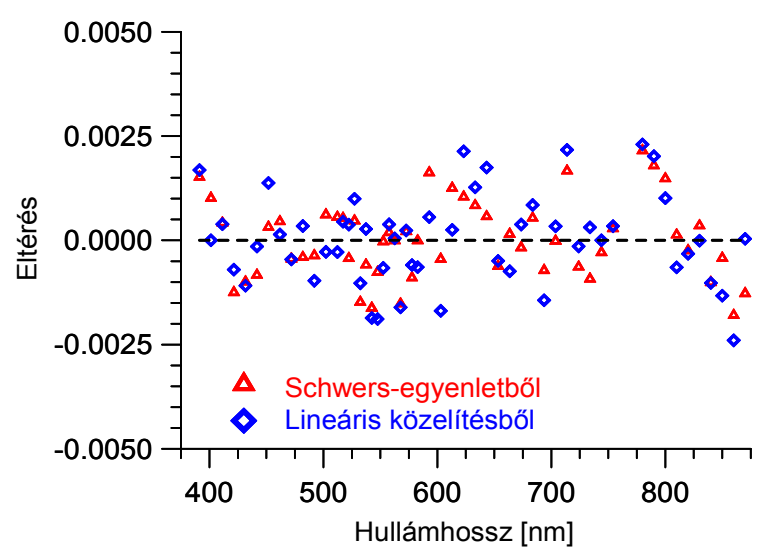

43. ábra - A bR mért és illesztett törésmutató-értékeinek eltérése

$\mathrm{Az}$ általunk meghatározott tiszta $\mathrm{bR}$ törésmutatója alapvetően különbözik a száraz mintán mért, $\mathrm{n}=1.52$ értékektől [143]. Ennek oka a sejtmembrán magas víztartalma, ami a mintakészítés után is megmarad, így a bR oldat törésmutatójának értéke közel van a desztillált vízéhez [141].

\begin{tabular}{lcccccc}
\hline bR szuszpenzió & $\mathrm{A}_{0}\left(10^{11}\right)$ & $\lambda_{0}[\mathrm{~nm}]$ & $\mathrm{A}_{1}\left(10^{4}\right)$ & $\mathrm{A}_{2}\left(10^{8}\right)$ & $\Lambda_{1}[\mathrm{~nm}]$ & $\Lambda_{2}[\mathrm{~nm}]\left(10^{3}\right)$ \\
\hline Schwers-egyenlet & 6.838 & 559.8099 & 2.40692062 & 8.1543917 & 58.928371 & 1445.266549 \\
Lineáris közelítés & 6.838 & 559.8099 & 2.42382645 & 7.5111726 & 58.540103 & 1012.51599 \\
\hline
\end{tabular}

5. táblázat - A bR Sellmeier-egyenletének együtthatói normál légköri nyomáson és $22^{\circ} \mathrm{C}$ hömérsékleten

\subsection{4. ÖSSZEFOGLALÁS}

Méréseim során vad típusú bR $\left(\mathrm{bR}_{\mathrm{Wt}}\right)$ mintákat vizsgáltam szuszpenzió formájában, amelyet TRIS $(10 \mathrm{mM}, \mathrm{pH}=7.0)$ pufferrel higítottam a 0-80 $\mu \mathrm{M}$ közti koncentráció tartományban. Először megmértem a TRIS puffer törésmutatóját, majd a bR szuszpenziók törésmutatóját különböző koncentrációkon 390-880 nm közti hullámhossztartományon, és meghatároztam a bR $\mathrm{Wt}_{\mathrm{t}}$ törésmutatójának koncentrációfüggését. Elsőként adtam meg a TRIS puffer és a bR szuszpenzió Sellmeier-együtthatóit [144].

1. tézispont: A minimális deviáció szögének méréséből meghatároztam a bR törésmutató értékeket. Először meghatároztam a TRIS puffer törésmutatóját, majd a bR szuszpenziók törésmutatóját különböző koncentrációkon $\quad 390-880 \quad \mathrm{~nm}$ közti hullámhossztartományon. Elsőként adtam meg a TRIS puffer és a bR szuszpenzió Sellmeier-együtthatóit. 


\subsection{ULTRAGYORS OPTIKAI KAPCSOLÁS BAKTERIORODOPSZINNAL}

Ormos és munkatársai a korábbi munkáik során kísérletileg kimutatták, hogy a fényindukált átmenet a BR $\rightarrow$ M állapotok között alkalmas optikai kapcsolásra [40]. Ez az átmenet azonban relatíve lassú, a $10 \mu$ s tartományba esik. Munkánk során megvizsgáltuk és kísérletileg igazoltuk, hogy a jóval gyorsabb (néhány ps) $\mathrm{BR} \rightarrow \mathrm{K}$ átmenet is eredményesen használható optikai kapcsolásra [34, 145]. Sőt, egy lépéssel továbbmenve, a bR eddig ismert leggyorsabb $(<0.5 \mathrm{ps}) \mathrm{BR} \rightarrow \mathrm{I}$ átmenetét is sikerült használni fénykapcsolásra, mellyel a $1 \mathrm{THz}$ kommunikációs sebesség elérése lehetővé válhat.

\subsubsection{MÉRÉSI EREDMÉNYEK}

A 22. ábrán bemutatott kísérleti elrendezésben a próba impulzus nagy spektrális sávszélessége miatt Fabry-Perot-interferométert építettünk, hogy - a rácsos becsatolás megfelelő pontosságú detektálásához szükséges - keskeny ( $0.2 \mathrm{~nm}$ alatti) pumpa impulzust használhassunk a mérések során. A 44. ábrán látható a próba impulzus teljes spektruma Fabry-Perotinterferométer után (44. a ábra), valamint kinagyítva a kísérleteinkhez használt $790 \mathrm{~nm}$-es központi hullámhosszú, keskeny sávszélességü nyaláb spektruma (44. $b$ ábra).
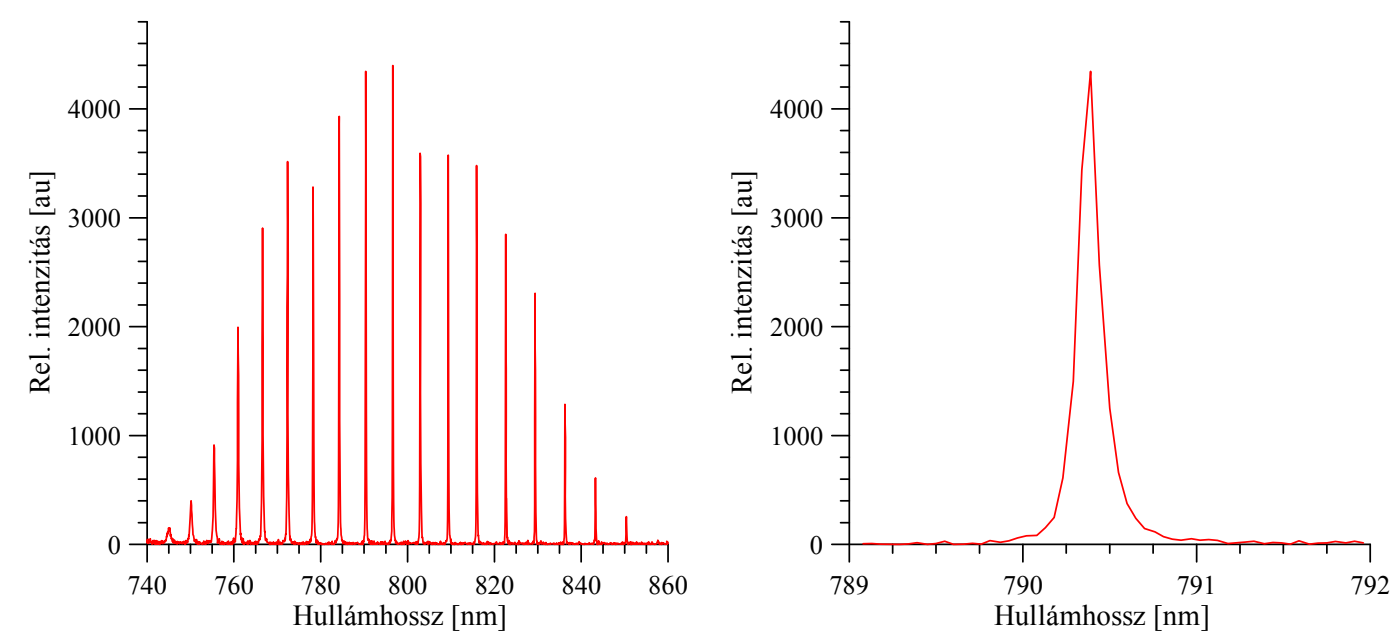

44. ábra - A próba impulzus spektruma a Fabry-Perot-interferométer után (a) valamint a 790 nm-es, keskeny sávszélességü rész spektrumának nagyítása (b), amelyet a mérések során mindvégig használtam

A $0.18 \mathrm{~nm}$ sávszélességü próba impulzust a hullámvezetőbe irányítottam, majd oszcilloszkópon megkerestem az intenzitás maximum segítségével a helyes becsatolási szöget 
a 790 nm-es (44. b ábra) impulzusokra. Méréseim során az optikai kapcsolás demonstrálására a TM rezonanciacsúcsot használtam -19.65 fokos becsatolási szögnél. Mielött eredményeimet ismertetem, röviden felvázolom a várható effektust.

A gerjesztést követően a bR törésmutató-változásának hatására a becsatolási szög megváltozik, így a hullámvezetőbe csatolt módus intenzitásának változását várjuk (amplitúdókapcsolás). A becsatolt módus intenzitását a rezonanciacsúcs inflexiós pontjainak közelében (például az intenzitás-félértékeknél) érdemes megfigyelni, hisz itt várható a legnagyobb intenzitás-változás. Ezt az elképzelést a 45. ábrán mutatom be.

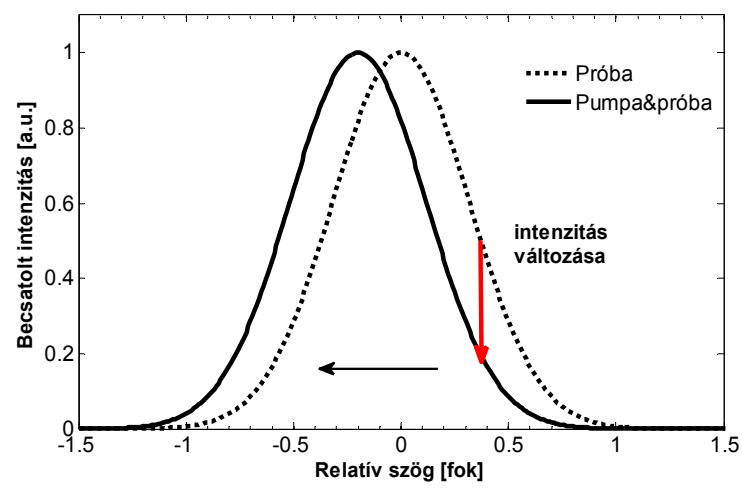

45. ábra - A szubpikoszekundumos mérés demonstrálása. A hullámvezetőbe csatolt fény intenzitásának rezonanciacsúcsa eltolódik a negatív szögek irányába az adlayer hipotetikus törésmutatójának csökkenése miatt. A piros nyíl jelzi a várható intenzitás változását a rezonanciacsúcs félértékénél, a spektum vörös oldalán.

A BR és I állapotok abszorpciós spektrumából a Kramers-Kronig-reláció alkalmazásával kiszámolható (2.9), hogy $790 \mathrm{~nm}$ hullámhosszon $(0.18 \mathrm{~nm}$ sávszélesség mellett) mekkora és milyen előjelü a törésmutató változása. Esetünkben ez az érték -0.002 körüli, amelyből kiszámolható, hogy az adott hullámhosszra vonatkozó becsatolási szög negatív irányba tolódik el. Tehát ha a 45. ábrán látható helyen (piros nyíl) vizsgáljuk a becsatolt intenzitást, a bR konformációjának változása miatt bekövetkező törésmutatóváltozás gerjesztés hatására a jelzett intenzitás csökkenését fogja eredményezni.

Méréseink során 150 fs impulzusidejü pumpa impulzussal gerjesztettük a bR fotociklusát, ezt követően különböző késleltetéseknél detektáltuk a félértéknél fellépő relatív intenzitás-változásokat. Ez a -19.65 fokos becsatolási szög esetében az óramutató járásával ellentétes (counter clockwise, CCW) irányban vett félértéket jelenti a kísérleti 
összeállításunkban. A pumpa és próba impulzusokkal $50 \mu \mathrm{m}$ vastag BBO kristályban összefrekvenciát keltve megkerestük $\mathrm{t}=0$ késleltetést. Majd e nulla késleltetésnél a CCW intenzitásmaximum félértékszélességénél a mért relatív intenzitásokat a 46. $a$ ábrán mutatom be. Látható, hogy a pumpa impulzus (zöld pontozott vonal) nulla körül ingadozik, vagyis nem szóródik be a méréseink során. A becsatolt próba impulzus (fekete szaggatott vonal) intenzitása pumpálás hatására lecsökken, melyet a pirossal jelzett folytonos vonal jelez. Ezt úgy is értelmezhetjük, hogy az adlayer törésmutatója gerjesztés hatására csökken. Ez a hatás összhangban van azzal a feltevésünkkel, hogy ezesetben az amplitudó-kapcsolást az I intermedier uralja a fotociklus során, mivel az I állapot fő abszorpciós csúcsa jelentősen kékeltolódott $\left(\lambda_{\mathrm{I}, \max }=460 \mathrm{~nm}\right)$ a BR alapállapothoz képest $\left(\lambda_{\mathrm{BR}, \max }=570 \mathrm{~nm}\right)$.

Mintegy ellenőrzésképpen megnéztem a másik oldali intenzitásfélértéknél (clockwise, $\mathrm{CW}$ ) is az optikai pumpálás hatását a becsatolt próba impulzusra. A 45. ábrának megfelelően itt intenzitásnövekedést kellene tapasztalnunk, amit a 46. $b$ ábrán látható mérési görbék is megerősítenek: a mért próbaimpulzus intenzitása pumpálás hatására megnő a spektrum rövidebb hullámhosszhoz tartozó oldalánál (piros folytonos vonal).

a)

b)
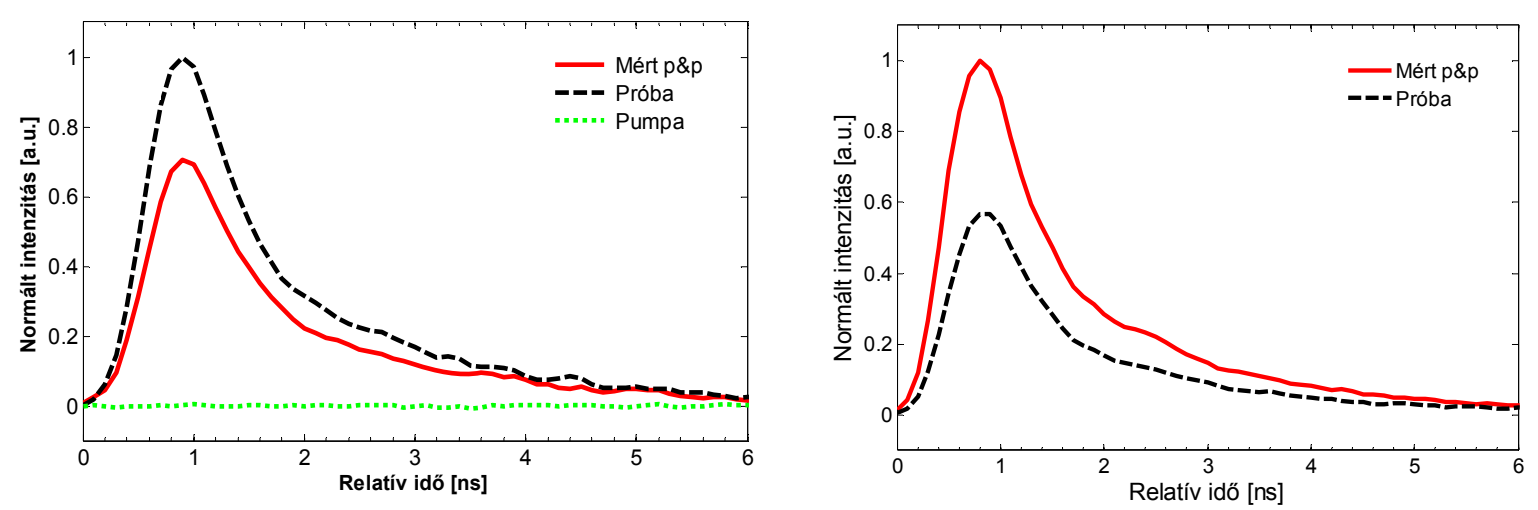

46. ábra - A detektáló fotodióda válaszjele a próba impulzus nulla késleltetésénél. (a) A hullámvezetőbe csatolt próba impulzus intenzitása a rezonancia csúcs hosszabb hullámhosszú félértékénél mérve pumpálással (folytonos piros) és pumpálás nélkül (szaggatott fekete). (b) A becsatolt próba impulzus intenzitása a rezonancia csúcs félértékének rövidebb hullámhosszhoz tartozó oldalánál mérve pumpálással (folytonos piros) és pumpálás nélkül (szaggatott fekete).

\subsubsection{ELMÉLETI MEGGONDOLÁSOK}

Ahhoz, hogy megvizsgáljuk annak a lehetőségét, hogy a bR fotonikai alkalmazása a leggyorsabb BR $\rightarrow$ I spektrális átmenetek között létrejöhet - 150 fs impulzusidejü gerjesztés 
alatt 3 ps-os próba impulzus mérésével - kinetikai elemzést kell végeznünk. Az alkalmazott pumpa és próba impulzusok rövidek voltak, valamint az ismétlési frekvencia $1 \mathrm{~Hz}$ volt, így elegendő a gerjesztést követő első 4 ps-os időtartományt vizsgálnunk.

Ha megnézzük a bR fotociklusát, látható, hogy csak a $H, I, J$ és $K$ állapotok keveréke jelenik meg a gerjesztést követő 4 ps-on belül (ld. 2. ábra). Ezen intermedierek sebességi állandóit felhasználva az irodalomból [30, 146-148] meghatározható, hogy mennyi a relatív hozzájárulásuk a próba impulzus fényindukált intenzitásváltozásához. Az irodalomból rendelkezésünkre álló adatokból, valamint a kísérleti körülményekből kiszámolható a $H, I, J$ és $K$ állapotok időbeli fejlődése (kialakulása és bomlása) a próba impulzusunk időtartama alatt. Számos kísérleti és elméleti kutatást végeztek, hogy felfedjék a gerjesztést követő ultragyors intramolekuláris eseményeket [30, 149-152]. Összegezve mindezeket, a gerjesztést követő Franck-Condon állapot $\left(\mathrm{H}_{560}\right)$ után a bR vibrációsan relaxált - kvázi-stacionárius - $\mathrm{S}_{1}$ állapotba $\left(\mathrm{I}_{460}\right)$, ezt követően pedig elektron-átmenettel a $\mathrm{J}_{625}$ állapotba jut. Mindez 500 fs-nál rövidebb idő alatt végbemegy. Ezt követően egy másik vibrációs-relaxációs folyamat vezet a $\mathrm{K}_{610}$ állapothoz, amely már 13-cis izomerizált retinál kromofórt tartalmaz.

Méréseim során a fotociklust intenzív $\left(3 \mathrm{~mJ} / \mathrm{cm}^{2}\right)$ és rövid (150 fs) pumpa impulzus indította be. A gerjesztést követően egy 3 ps-os próba impulzust használtam a szárított bR minta törésmutató-változásának nyomon követésére. A próba impulzus jelenlétekor mindegyik korai állapot egyidejüleg jelen van a mintában, így a mért jel mindegyik állapot hozzájárulását tartalmazza. A számolásom során az alábbi fotociklus modellt (beleértve az alapállapotot: BR állapot) használtam:

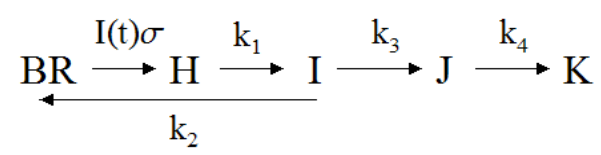

A BR abszorpciós hatáskeresztmetszete $(\sigma) 530 \mathrm{~nm}$-en $0.76 \cdot 10^{-16} \mathrm{~cm}^{2}$. Az átmenetekhez tartozó elsőrendủ sebességi állandókat a nyilak fölött találhatjuk az (5.3) folyamatábrán. A minta $I_{\text {pump }}(t)$ gerjesztését $\tau=150$ fs félértékszélességü Gauss-impulzussal modelleztem. Az intermedierek koncentrációinak időbeli fejlődését numerikus számolással megkaphatjuk, alkalmazva az alábbi elsőrendű sebességi differenciálegyenlet-rendszert: 


$$
\begin{aligned}
& \frac{\mathrm{d}}{\mathrm{dt}}[\mathrm{BR}]=-\mathrm{I}_{\mathrm{PUMP}}(\mathrm{t}) \sigma[\mathrm{BR}]+\mathrm{k}_{2}[\mathrm{I}] \\
& \frac{\mathrm{d}}{\mathrm{dt}}[\mathrm{H}]=\mathrm{I}_{\text {PUMP }}(\mathrm{t}) \sigma[\mathrm{BR}]-\mathrm{k}_{1}[\mathrm{H}] \\
& \frac{\mathrm{d}}{\mathrm{dt}}[\mathrm{I}]=\mathrm{k}_{1}[\mathrm{H}]-\left(\mathrm{k}_{2}+\mathrm{k}_{3}\right)[\mathrm{I}] \\
& \frac{\mathrm{d}}{\mathrm{dt}}[\mathrm{J}]=\mathrm{k}_{3}[\mathrm{I}]-\mathrm{k}_{4}[\mathrm{~J}] \\
& \frac{\mathrm{d}}{\mathrm{dt}}[\mathrm{K}]=\mathrm{k}_{4}[\mathrm{~J}]
\end{aligned}
$$

Itt $[\mathrm{X}](\mathrm{t})$ az $\mathrm{X}$ állapot időfüggő koncentrációját jelöli (beleértve a $B R$ alapállapotot is), és $\mathrm{k}_{\mathrm{i}} \mathrm{az}$ $i$-edik elsőrendủ átmenetnek megfelelő sebességi állandó.

Az alábbi sebességi állandókat használtam a MATLAB beépített Newton-módszerével történő számolások során:

- Az $1 / \mathrm{k}_{1}$ az I-állapot megjelenése (30 fs) [149, 151].

- A $\mathrm{k}_{2}$ és $\mathrm{k}_{3}$ meghatározása az I-állapot lecsengéséből történt: $1 /(\mathrm{k} 2+\mathrm{k} 3)=500$ fs $[150$, 152], továbbá $\mathrm{k}_{3} / \mathrm{k}_{2}$ számolása a fotociklus kvantumhatásfokának kísérleti meghatározásából történt (annak a valószínűsége, hogy egy gerjesztett állapotban (I) levő molekula $J$ és onnan további-, vagy alapállapotba kerül). Száraz minta esetén ezt 63 $\%$-nak találták [30], ezért $\mathrm{k}_{3} / \mathrm{k}_{2}=63 / 37$.

- $\quad \mathrm{A} \mathrm{k}_{4}$ a $K$-intermedier felhalmozódásának időállandóját jelöli (3ps) [148].

A kezdeti állapotokra vonatkozó nyilvánvaló feltétel, hogy $\mathrm{t}=0$ időpillanatban $\mathrm{a} b \mathrm{R}$ alapállapot relatív koncentrációja 1, minden más állapoté pedig zérus. A (5.4) diferrenciálegyenlet fenti értékekkel való megoldását a 47. ábra szemlélteti.

Mivel a $B R$ és $H$ állapotok között a spektrális eltolódás elhanyagolható, a jelentős spektrális eltolódás csak az I intermedier fejlődésénél kezdődik. Ezért elhanyagolható a $H$ hozzájárulása a mért effektusunkhoz, és az egyszerüség kedvéért kihagytam a 47. ábrán.

A mért jelek értelmezése céljából az egyszerüség kedvéért először tételezzük fel, hogy ahhoz minden állapot a koncentrációjával arányos módon járul hozzá. Az egyes állapotoknak a próba impulzus által kiváltott optikai jelhez való súlyozatlan hozzájárulása a megfelelő állapot koncentrációja és a próba impulzus időbeli fejlődésének konvolúciójaként számítható ki. Minthogy a detektorunk válaszideje a tanulmányozott jelenségekhez képest lassú $\left(<^{\circ} 4^{\circ} \mathrm{ps}\right.$ illetve $\sim 1$ ns felfutási idő), a 46. ábrákon bemutatott detektált jelek nagysága a konvolúció során nyert függvény teljes időskálára számított határozott integráljával lesz arányos. Számításaink eredménye szerint ezen integrálok relatív értéke az $I, J$ és $K$ állapotokra 
vonatkozólag 53\%, 39\% és $8 \%$. A tényleges hozzájárulás számolása esetén az imént kapott értékeket súlyozni kell az egyes állapotok és a BR alapállapot törésmutatójának 790 nm-nél fennálló különbségével [34]. Figyelembe kell továbbá venni, hogy a $\mathrm{BR}_{570}$ és az $\mathrm{I}_{460}$ között nagyobb a spektrális eltolódás (ld. 3. ábra), ez a Kramers-Kronig-reláció szerint nagyobb abszolút törésmutató-változásnak felel meg, mint a $\mathrm{J}_{625} \rightarrow \mathrm{BR}_{570}$ és a $\mathrm{K}_{610} \rightarrow \mathrm{BR}_{570}$ állapotok közti eltolódások.

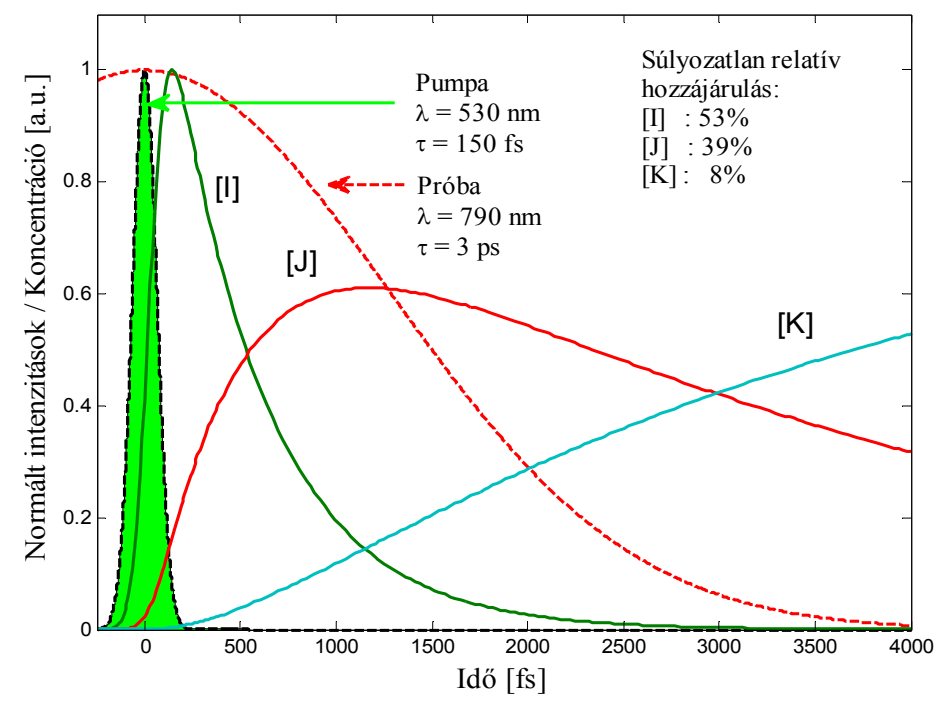

47. ábra - A bakteriorodopszin H, I, J és K állapotainak számolt időfejlődése

Összegezve tehát arra a következtetésre juthatunk, hogy a mért effektust több mint 53 \%-ban az $I$ állapot uralja, míg a $J$ és $K$ állapotok jóval kisebb hatással vannak a próba impulzusra ( $\sim 39^{\circ \%}$ illetve $\sim 8^{\circ \%}$ ). Továbbá, az $I, J$ és $K$ állapotokra jellemző fő abszorpciós csúcsok spektrális eltolódásának nagyságát és irányát a BR állapothoz viszonyítva (110 nm kék; 55 $\mathrm{nm}$ vörös; $40 \mathrm{~nm}$ vörös) szintén a kék-eltolódás jellemző $\mathrm{t}=0$ késleltetésnél, ami összhangban van a mért eredményeinkkel.

\subsection{3. ÖSSZEFOGLALÁS}

Integrált optikai hullámvezető felületére vékony bR film réteget helyeztem. Pumpa-próba méréssekkel kimutattam, hogy a bR abszorpciója miatt bekövetkező törésmutató-változás (azaz optikai pumpálás) hatására a hullámvezetőbe csatolt módus rezonancia csúcsa eltolódik a gerjesztést követően szubpikoszekundumos idő alatt. Mérési eredményeimet összevetettem 
a bR fotociklusára vonatkozó időállandók értékeivel, amelyek alapján számolással igazoltam, hogy a mért jel intenzitásváltozását főként a $\mathrm{BR} \rightarrow \mathrm{I}$ átalakulással együtt járó törésmutatóváltozás dominálja.

A fenti eredmények mutatják, hogy a bR fotociklusának $B R \rightarrow I$ átmenete alkalmazható ultragyors, tisztán optikai elven müködő fénykapcsolásra. Várhatóan hatékonyabb kapcsolást lehet elérni a jövőben a fehérje minta megfelelő módosításával (pl. a fotociklust meg lehet állítani $J$ állapotban a kromofór kémiai módosításával), vagy hűtésével a K állapotban [149, 153]. Az itt bemutatott elv alapja lehet a jövőben egy fehérje alapú integrált optikai eszköz megvalósításának. Hasonló eszközök használatával a teljesen optikai elven müködő kapcsolás forradalmasítható, a jelenlegi néhányszor $100 \mathrm{GHz}$ a jövőben elérheti az 1 THz-es határt is.

2. tézispont: Integrált optikai hullámvezető felszínére szárított vékony bR réteget alkalmazva pumpa-próba mérésekkel kimutattam, hogy a bR abszorpciója miatt bekövetkező törésmutató-változás hatására a hullámvezetőbe csatolt vezetett módus rezonanciacsúcsa a gerjesztést követően szubpikoszekundumos idő alatt eltolódik. Mérési eredményeimet összevetettem a bR fotociklusára vonatkozó időállandók értékeivel, amelyek alapján számolással igazoltam, hogy a mért jel intenzitás-változását főként a $\quad B R \rightarrow I$ átalakulással együtt járó törésmutató-változás dominálja. Az eredmények egyértelmúen mutatják, hogy a bR fotociklusának $B R \rightarrow I$ átmenete alkalmazható ultragyors, tisztán optikai elven múködő fénykapcsolásra. 


\subsection{A FAD FLUORESZCENCIA KINETIKÁJÁNAK VIZSGÁLATA KÜLÖNBÖZŐ MIKROKÖRNYEZETEKBEN}

Az alábbi fejezetben bemutatom a FAD időbontott fluoreszcencia spektrumainak mérésének eredményét a víz, etanol, dioxán, DMSO és FCC környezetekben, majd részletezem a kinetikák analízisét, és összefoglalom eredményeimet.

\subsubsection{A FAD FLUORESZCENCIÁJÁNAK MÉRÉSE KÜLÖNBÖZÖ MIKROKÖRNYEZETEKBEN}

Az időbontott fluoreszcencia mérések előtt megmértem a $3 \cdot 10^{-3}$ M-os FAD törzsoldatok sztatikus (steady-state) abszorpcióját az 50mM-os, $\mathrm{pH}=7.0$-s foszfát pufferben. A mért abszorpciós spektrumot a 48. ábrán mutatom be.

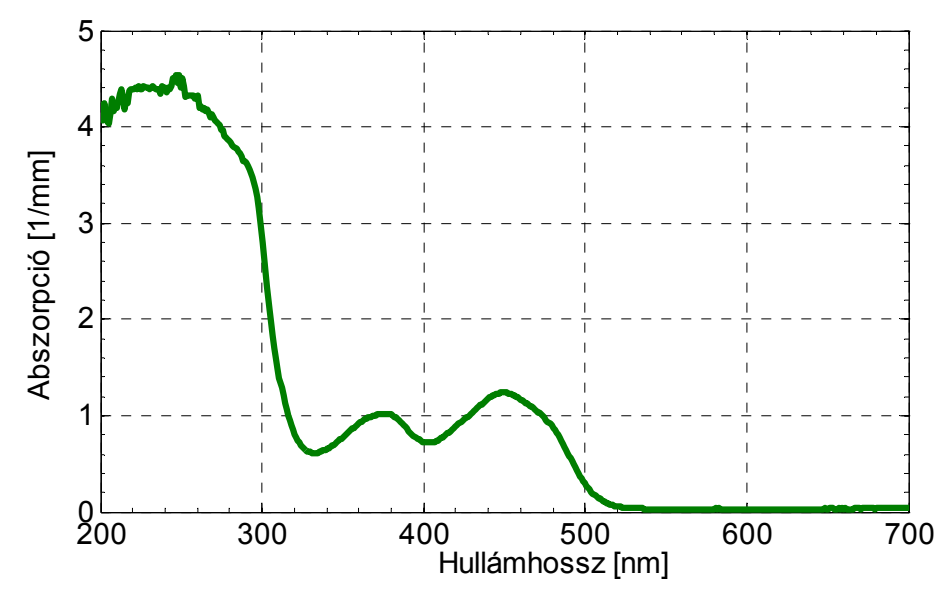

48. ábra - A FAD törzsoldat abszorpciós spektruma $50 \mathrm{mM}$, $\mathrm{pH}=7.0$-s foszfát pufferben

Az idő és hullámhossz függvényében nyert jellegzetes kísérleti fluoreszcencia adatok a 49. ábrán láthatók. Ezek az adathalmazok igen komplex információt tartalmaznak az egyes komponensek kinetikai jellemzőiről, valamint a hozzájuk tartozó spektrumok időbeli változásairól. A könnyebb áttekinthetőség érdekében az adatokat 3D és színkódos ábrázolásban is bemutatom néhány esetben. A sötétvörös a legnagyobb, a sötétkék a legkisebb fluoreszcencia intenzitásnak felel meg. 

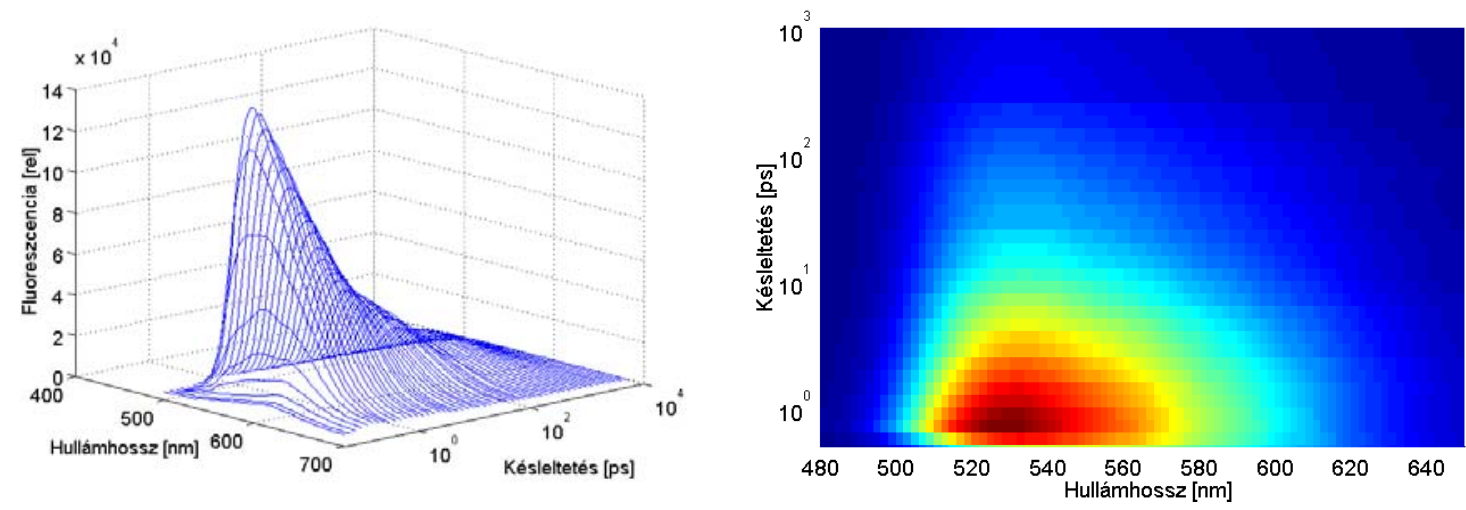

49. ábra - A FAD fluoreszcenciája $50 \mathrm{mM}$ Foszfát pufferben $\mathrm{pH}=7.0$

Vizes oldatban semleges pH mellett (49. ábra) a 100 fs-os időtartományba eső növekedési szakaszban a spektrumok erős kék eltolódása a csörp következménye. A lecsengési szakasz többfázisú, és nagyrészt a 100 ps-os tartományon belül bekövetkezik. Ez összhangban van azzal a megfigyeléssel, hogy vizes fázisban a molekulák döntő többsége összehajtott konformációban van $[65,154,155]$.
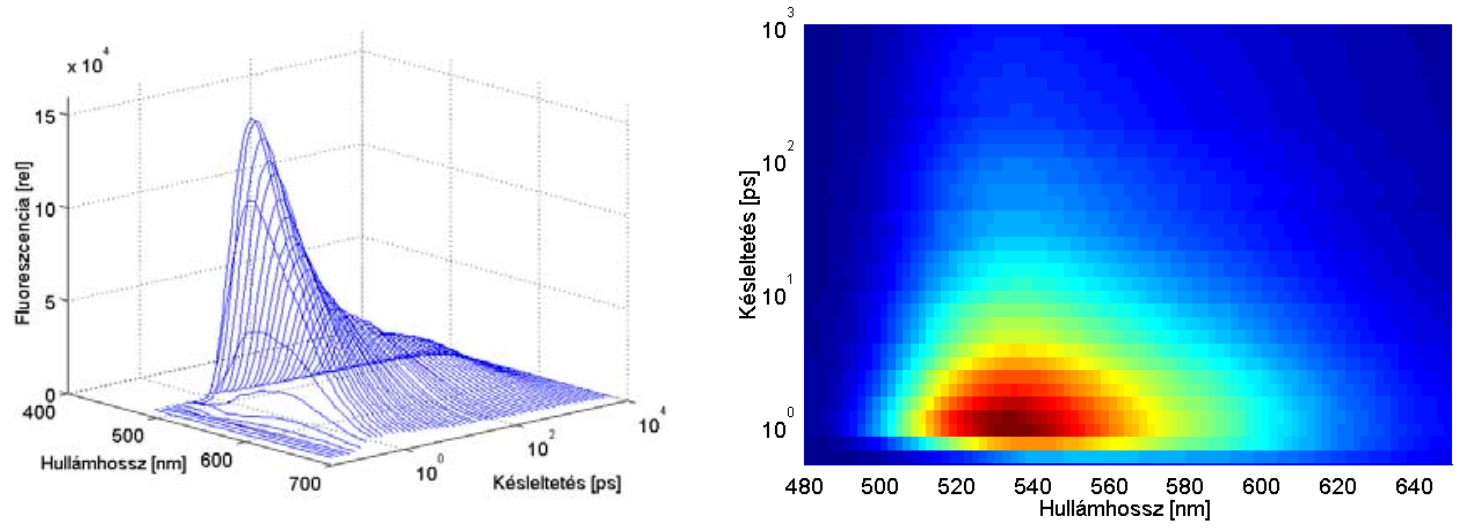

50. ábra - A FAD fluoreszcenciája $50 \mathrm{mM}$ Foszfát pufferben $\mathrm{pH}=6.0$

Ez a kép alig változik, ha a pH értéket egy egységgel csökkentjük (50. ábra) vagy növeljük (51. ábra). Ez összhangban van azzal, hogy extrém kis és nagy pH értékek kivételével vizes közegben a FAD molekula stabil [156], valamint Islam és mtsi. megállapításával, mely szerint a fluoreszcencia kinetika vizes oldatban az 5-9 pH tartományban nem változik [58]. 

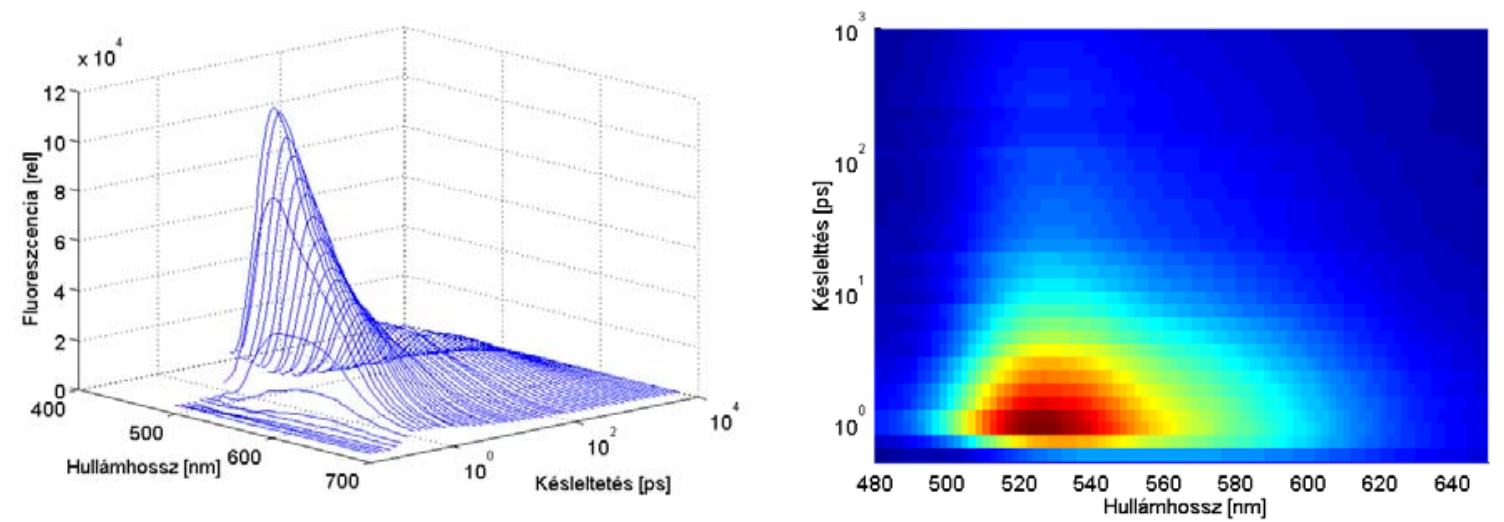

51. ábra - A FAD fluoreszcenciája $50 \mathrm{mM}$ Foszfát pufferben $\mathrm{pH}=8.0$

Ismeretes, hogy etanol hozzáadásával az összehajtott konformációban lévő molekula szerkezete kinyílik, és ennek megfelelően a fluoreszcencia életidő megnövekszik [65]. Ez a jelenség jól látható az 52. ábrán.
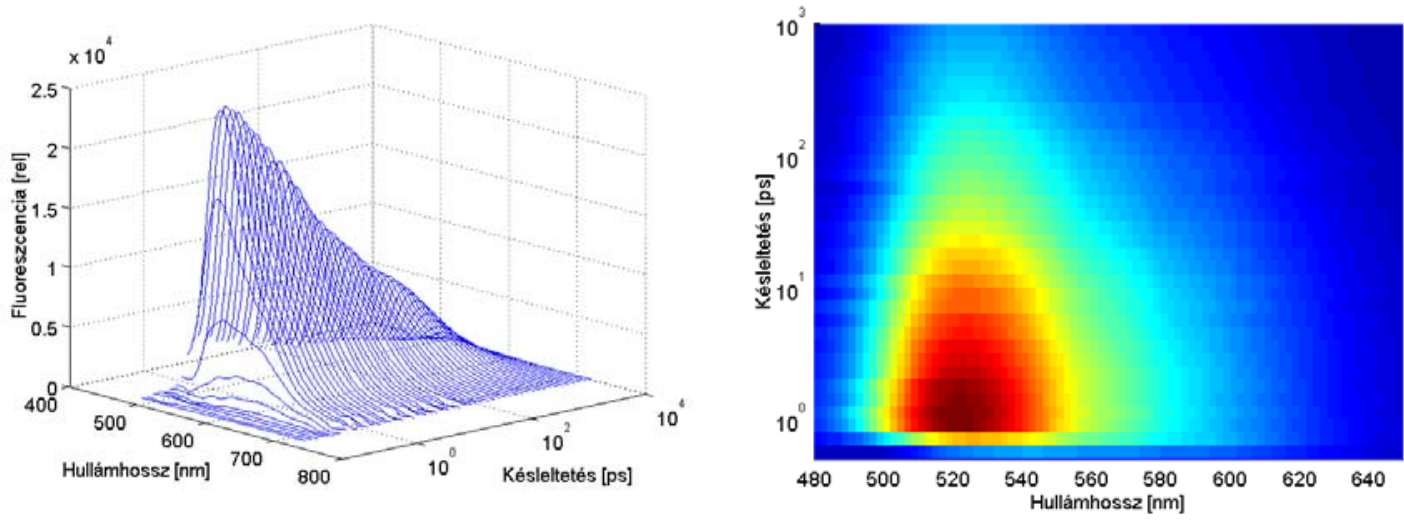

52. ábra - A FAD fluoreszcenciája etanol-víz 1:1 arányú keverékében $\mathrm{pH}=7.0$

NMR mérések során bebizonyították, hogy a nyílt konformáció létrejöttét dioxán hozzáadása is elősegíti. Emellett azt is megállapították, hogy a dioxán H-hidat képez az izoalloxazin gyürüvel [157]. A dioxánnak a fluoreszcencia kinetikára gyakorolt hatását ez idáig nem tanulmányozták. Az 53. ábrán megfigyelhető, hogy az alkoholhoz képest a dioxán hozzáadása további jelentős életidő növekedést eredményezett, továbbá a spektrumok is kiszélesedtek. (Az ábrán a spektrum kék oldalát $500 \mathrm{~nm}$ alatt nem tudtam kiértékelni, mert a víz $3400 \mathrm{~cm}^{-1}$ közelébe eső intenzív kettős Raman vonalától származó 463 nm-nél megjelenő csúcs torzítja a fluoreszcencia spektrumot.) 

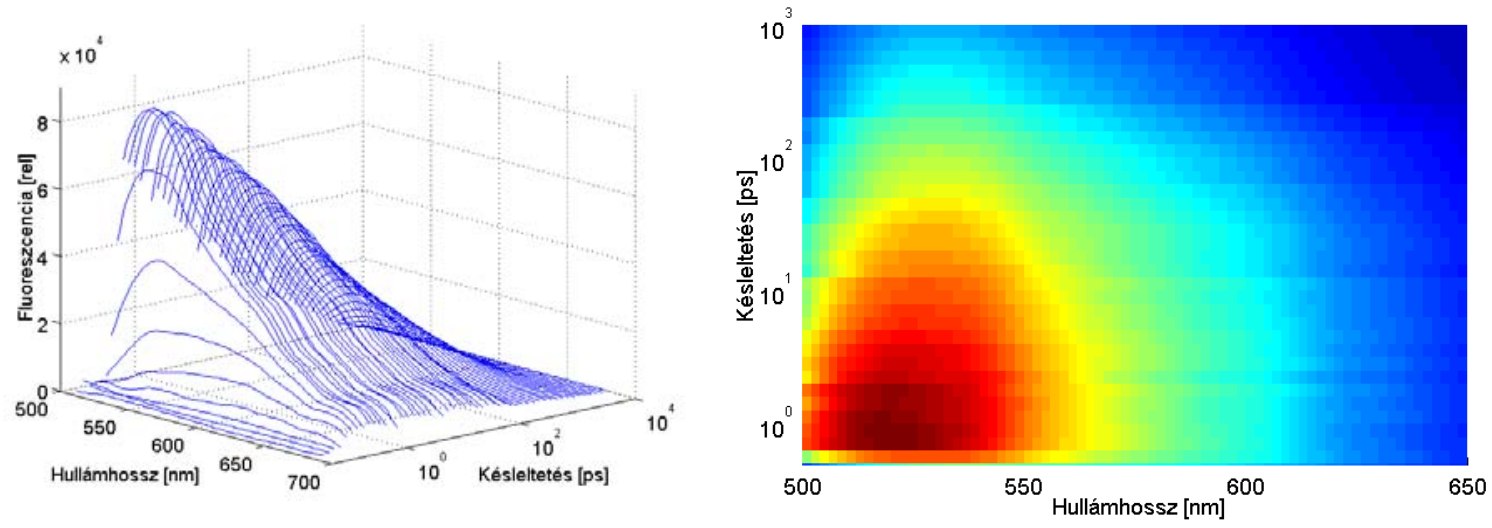

53. ábra - A FAD fluoreszcenciája dioxán-víz 1:1 arányú keverékében $\mathrm{pH}=7.0$

Femtoszekundumos IR tranziens abszorpciós vizsgálatok alapján megállapították, hogy a nyílt konformációt a víznél lényegesen kevésbé poláros dimetil sulfoxid (DMSO) hozzáadása is generálja [154]. Fluoreszcencia kinetikai méréseket eddig ezen a rendszeren sem végeztek. Az 54. ábrán feltüntetett adatokból látható, hogy DMSO jelenlétében a fluoreszcencia a vizes és alkoholos mintákhoz képest kék eltolódást mutat, továbbá a spektrumok strukturáltabbak. A fluoreszcencia életidő jelentősen hosszabb a vizes mintákénál, de rövidebb, mint alkohol vagy dioxán esetén.
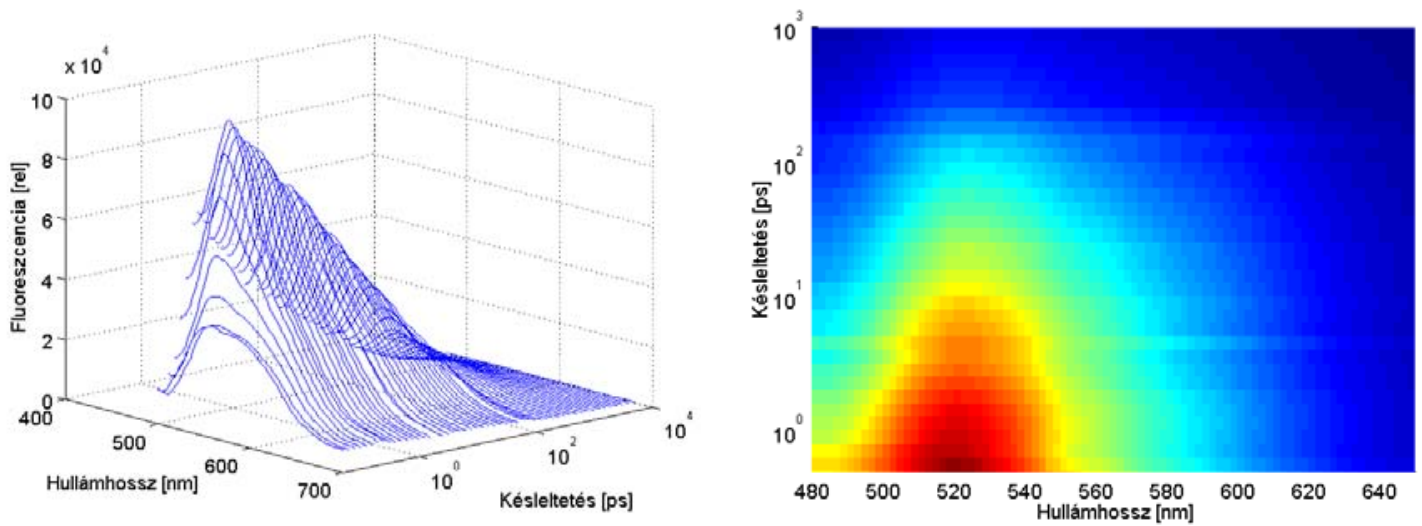

54. ábra - A FAD fluoreszcenciája DMSO-víz 1:1 arányú keverékében $\mathrm{pH}=7.0$

A különböző vizes oldatok mérései után az FCC fehérjéhez kötött FAD-ot tanulmányoztam, amely esetünkben a Thiocapsa roseopersicina baktériumból lett izolálva. A fehérje szerkezetét az 55. a ábrán mutatom be. A folyadék fázisban oldott FAD molekulákkal ellentétben az FCC-n végrehajtott Röntgen-diffrakciós vizsgálatok eredményeképpen a hozzá 
kötődő FAD molekula pontos konformációs állapota is ismert (55. $b$ ábra). Jól látható, hogy fehérjéhez kötött állapot esetén a FAD alapvetően nyitott konformációs szerkezetet mutat.
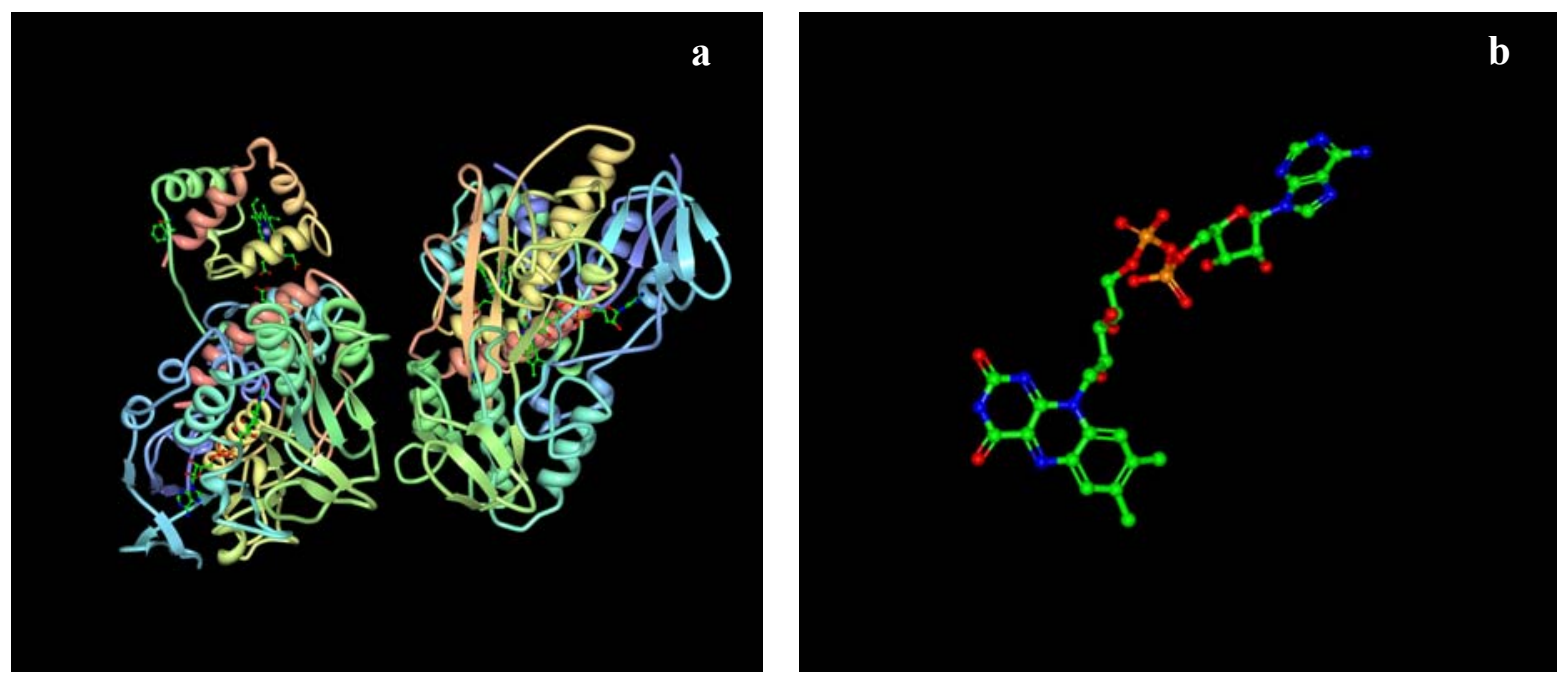

55. ábra - Az FCC fehérje szerkezete (a) külön kiemelve a hozzá kötődő

FAD molekula konformációját (b) [158]

Az időbontott méréseim előtt szintén megmértem a törzsoldat abszorpciós spektrumát, amely az 56. ábrán látható. A nem kötött FAD - mint azt a 48. ábrán is láthattuk - a $400 \mathrm{~nm}$ körüli hullámhossz-tartományban kicsit más abszorpciós spektrummal jellemezhető.

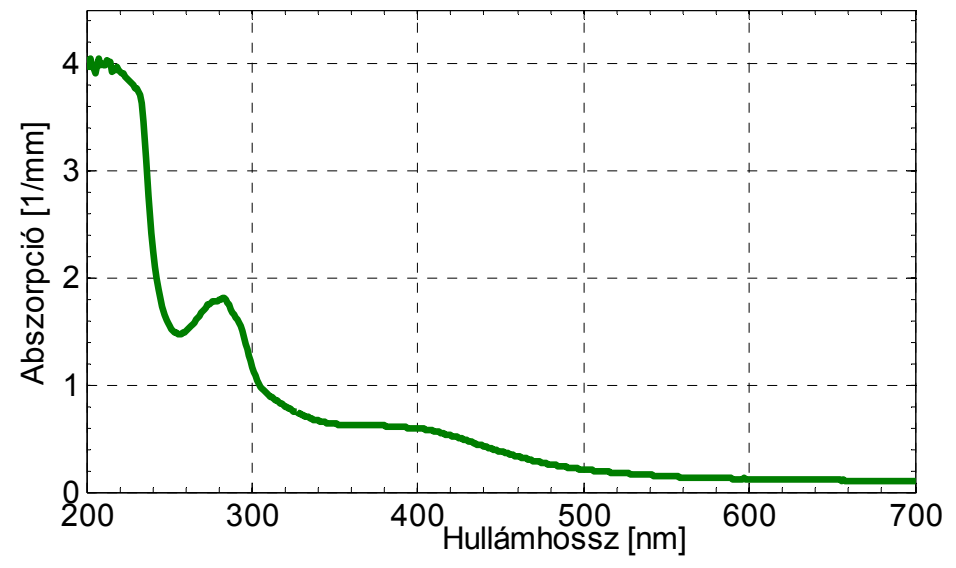

56. ábra - A flavocitokrómhoz kötött FAD abszorpciós spektruma

Minthogy FCC esetén közel sem érhető el akkora kromofór koncentráció, mint oldatban, a fehérjéből származó időbontott fluoreszcencia jelek ebben az esetben lényegesen kisebbek voltak. A lényegesen megnövekedett mérési idők következtében FCC-n széles hullámhossz tartományban csak a TCSPC módszerrel készültek mérések, a felkonvertálásos módszerrel 
egyelöre csak néhány kiválasztott hullámhosszon. A TCSPC mérések eredményeit az 57. ábrán mutatom be. A különböző oldatokban mért FAD fluoreszcenciájához képest szembetünő a különbség, hogy az 530 nm-s csúcson kívül megjelenik egy annál intenzívebb csúcs is 465 nm-es maximummal. Ezen kívül a fluoreszcencia lecsengése is sokkal gyorsabb.
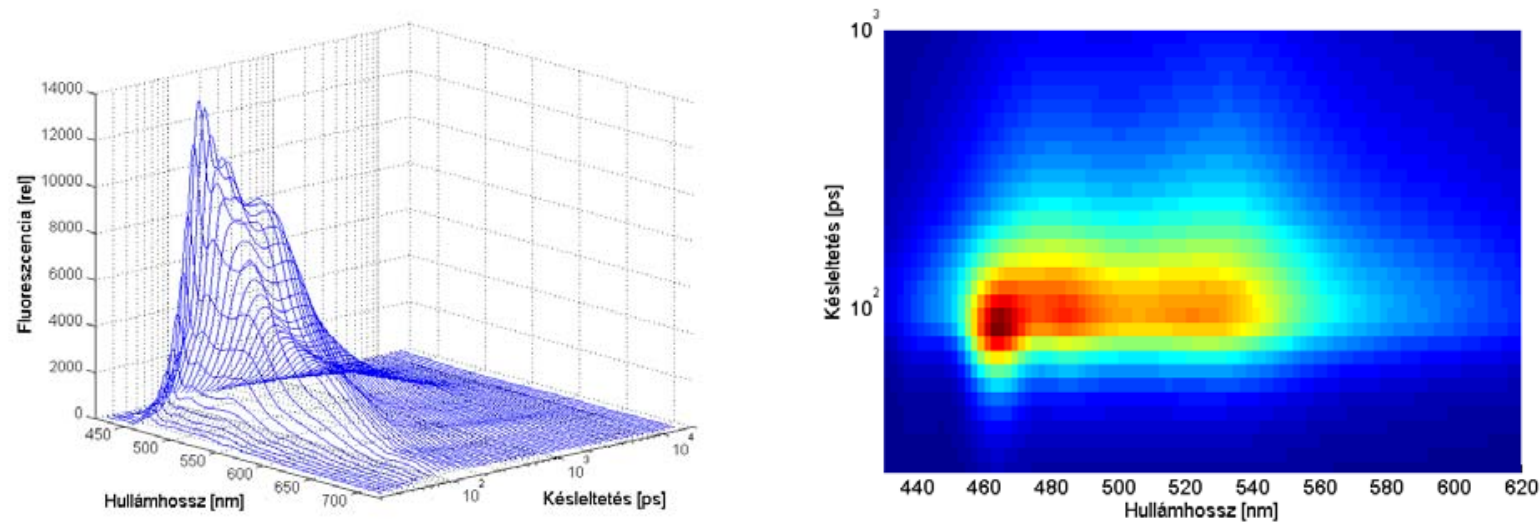

57. ábra - A flavocitokrómhoz kötött FAD fluoreszcenciája

\subsubsection{ANALÍZIS ÉS EREDMÉNYEK}

Az imént bemutatott, különböző mikrokörnyezetekben mért FAD idő- és hullámhosszbontott fluoreszcenciáját a BPDN optimalizációs eljáráson alapuló multiexponenciális illesztéssel analizáltam. Szemben a gyakran alkalmazott globális analízissel, a különböző hullámhosszakon mért fluoreszcencia kinetikák egymástól függetlenül lettek kiértékelve. Az adatok jel/zaj viszonya magasabb volt a TCSPC módszerrel mért szakaszban, amely méginkább nőtt a logaritmikus tömörítés során. A fluoreszcencia intenzitásnak a teljes adatsorra vonatkozó maximális értékére normalizált zajszint jellegzetes standard deviációja $\delta$ $=5 \times 10^{-3}$ körüli érték volt. Ennek megfelelően a regularizációs paramétert $\lambda=3 \times 10^{-4}$ értéknek állítottam be, amely az elözetes szimulációink során tapasztaltak szerint ehhez a zajszinthez optimálisnak bizonyult. [129]. Az analízis eredményét a FAD vizes oldatán $(\mathrm{pH}=8.0)$ az 580 nm-en mért fluoreszcencia kinetika esetében az 58. ábrán mutatom be. A felső ábra (58.a) a BPDN analízis során kapott időállandó-eloszlást mutatja $\left(\mathrm{t}_{0}=496 \mathrm{fs} ; \mathrm{IRF}_{\mathrm{fwhm}}=262 \mathrm{fs} ; \delta=\right.$ $2.38 \times 10^{-3}$ ). Látni, hogy az időállandók eloszlása ritka (sparse), néhány nagyon élesen meghatározott nemzérus értékböl áll. A középső ábrán (58.b) a mért (kék görbe) és az analízis eredményéből visszaszámolt, (piros pont) egyre normált kinetika látható. Az alsó ábrán (58.c) pedig a mért és számolt kinetikák közti eltérést mutatom be. Az eltérés \pm 0.005 értéken belül 
van, ami nagyon jónak mondható, és semmilyen struktúrát nem mutat. (A 250 ps-nál jól elkülönül a két méréstechnikára jellemző zajszint.)
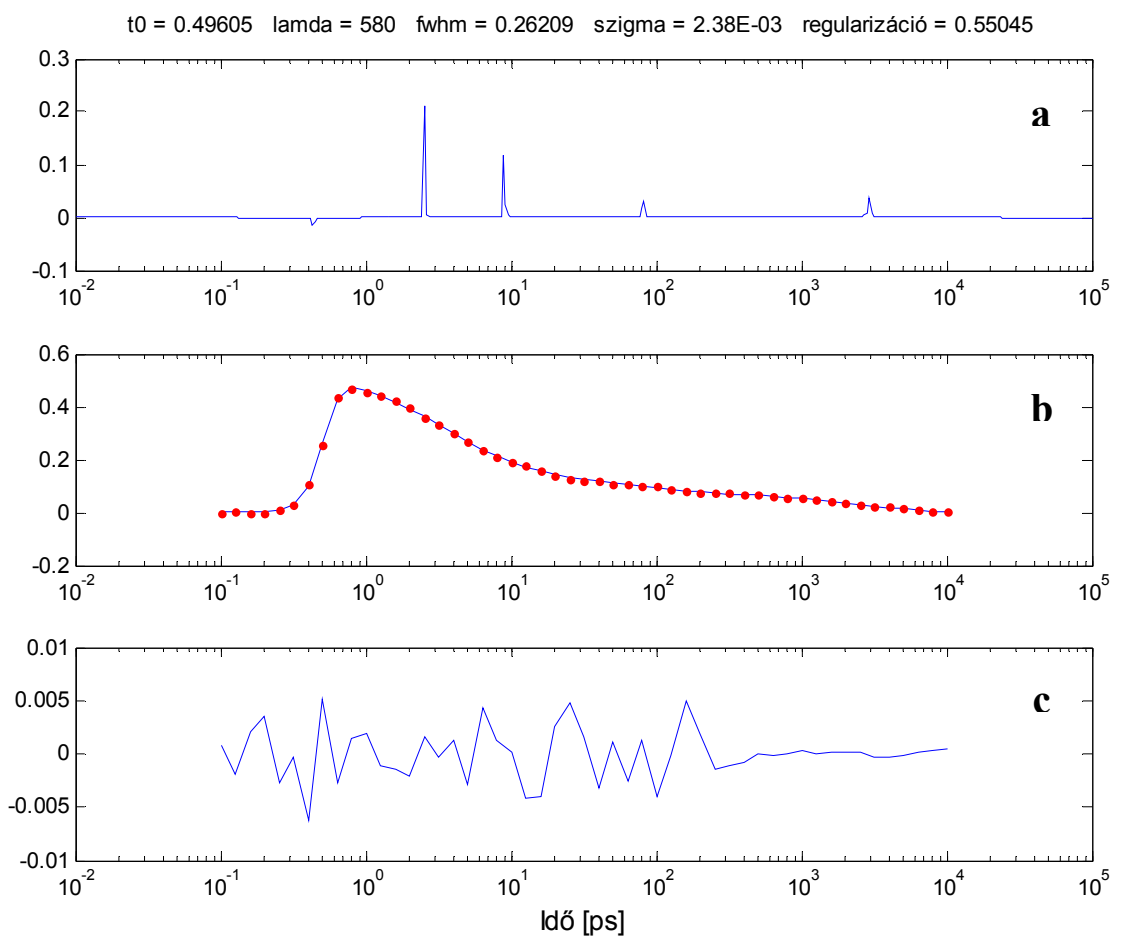

58. ábra - A FAD fluoreszcencia lecsengése vízben 580 nm-en $(\mathrm{pH}=8.0)$ a) A BPDN alanízis során kapott időállandók a hozzájuk tartozó amplitudók függvényében; b) A mért (kék) és visszaszámolt (piros) kinetika 580 nm-en; c) Az illesztés eltérése.

A mért és az illesztések során visszakapott FAD fluoreszcencia kinetikák nagyon jó egyezést mutatnak a teljes spektrális tartományon (59. ábra).

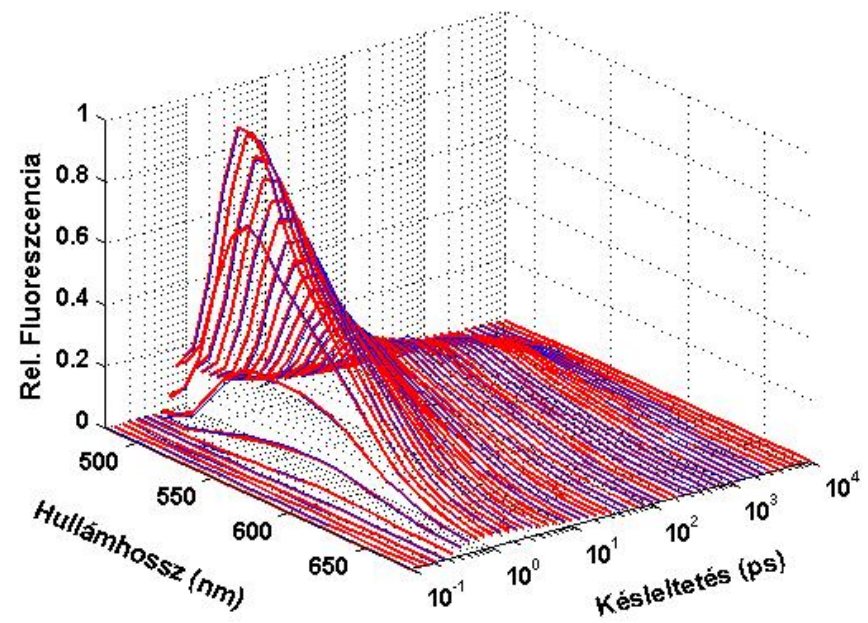

59. ábra - A FAD idő- és spektrálisan bontott fluoreszcenciája vízben ( $\mathrm{pH}=8.0)$

(kék: mért fluoreszcencia; piros: a BPDN analízis eredményeképpen rekonstruált fluoreszcencia, $\lambda=3 \times 10^{-4}$ ) 
Az illesztés során nyert időállandók és amplitudók hullámhossz szerinti eloszlását a 60 . ábrán foglaltam össze. A 2D ábrán zöld színnel jelölöm a nulla, pirossal a pozitív, kékkel pedig a negatív amplitudó-értékeket. Figyelemre méltó, hogy az időállandók eloszlása nagyon „ritka” és a teljes hullámhossz-tartományon át az amplitudók nagyon szük eloszlást mutatnak, annak ellenére, hogy az illesztések hullámhossz-függetlenül történtek. Alacsony hullámhosszon ugyan megfigyelhető kisebb hullámzás, elmosódás az időállandókban, azonban nagy valószínüséggel ezt a mérések rosszabb jel/zaj viszonya okozza. Ez a 2D amplitudó-eloszlás egyértelműen jelzi, hogy a kinetika valóban diszkrét, különben az időállandók hullámhossz menti eloszlása diffúzabb és kevésbé szeparált lenne.

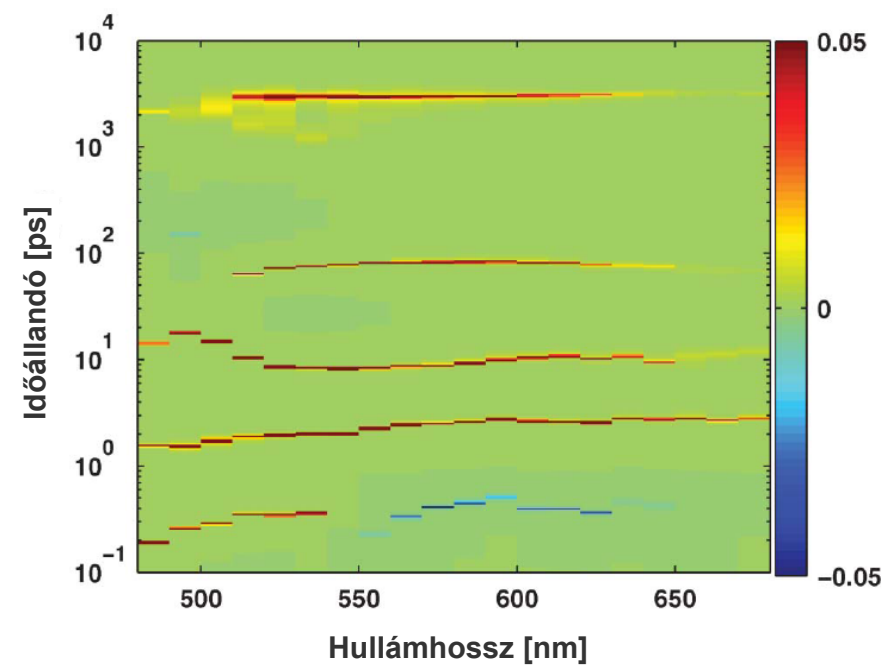

60. ábra - A kapott amplitudók eloszlása a hullámhossz és az időállandók terében (az 54. ábra mérésének BPDN analíziséből)

Mint az 58. és 60. ábrák mutatják, a kinetikák minden egyes hullámhosszon jól jellemezhetők öt időállandóval, melyek átlagos értéke: 500 fs, 2 ps, 10 ps, 80 ps és 3 ns. Ha részletesebben szeretnénk tanulmányozni az eredményeinket, akkor a kapott időállandók és amplitudók spektrumait célszerübb külön-külön szemügyre venni. A 61. a ábrán (felül) az időállandók hullámhosszfüggését szemléltetem. A vonalak pontjai egy adott hullámhosszon (mint pl. az 58. $a$ ábra, $580 \mathrm{~nm}$-en) az időállandók statisztikai súlyozott átlagából lettek kiszámolva - az egyes csúcsokhoz tartozó amplitudók (jellegzetesen 2-3 érték), mint súlyozási faktorok alkalmazásával. Az amplitudók összegének hullámhosszfüggését pedig a 61 . $b$ ábra mutatja. Ez az ábra maga az amplitudó spektrum, a DAS, amelyet az irodalomban gyakran használnak a hagyományos kinetikai elemzések során [159, 160]. 


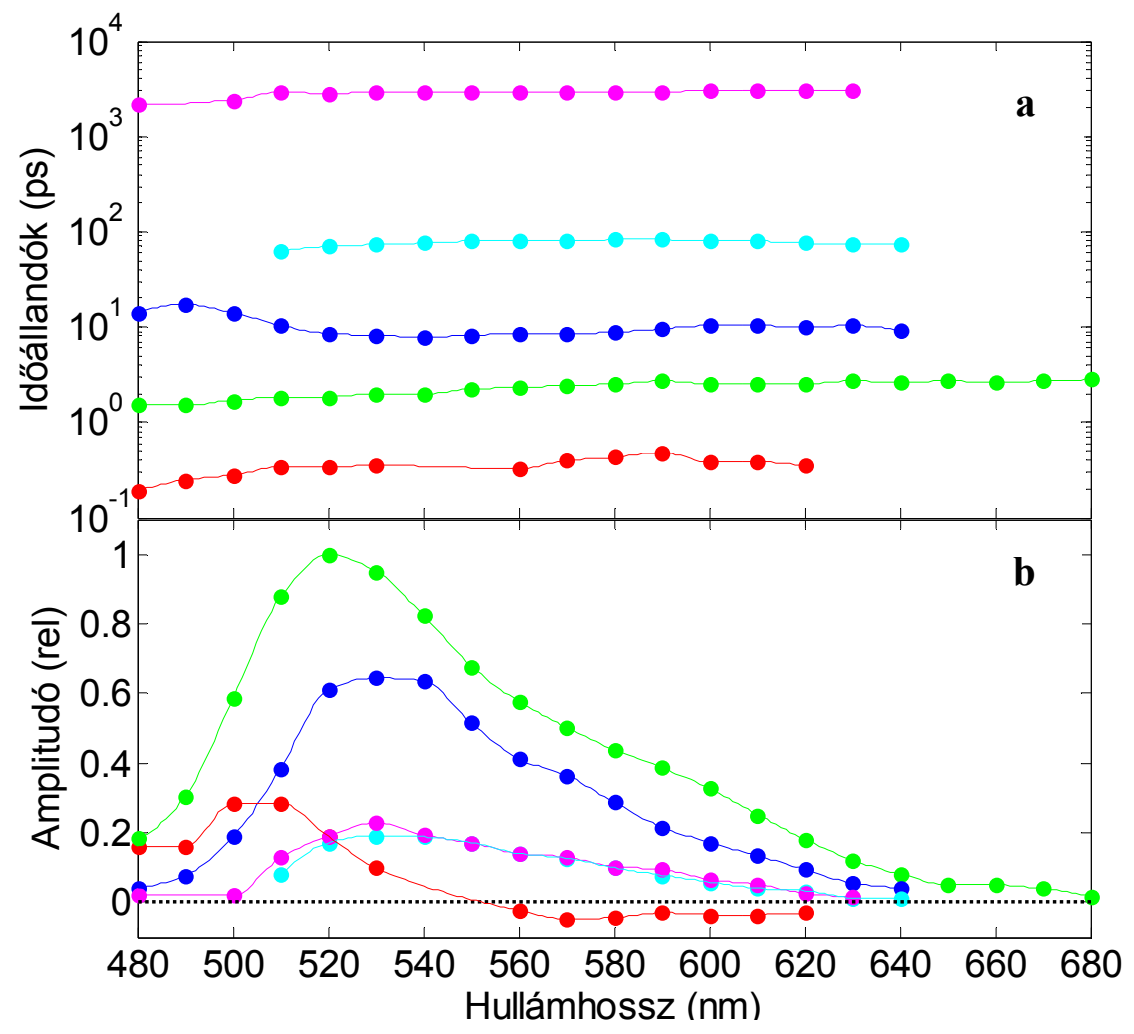

61. ábra - A BPDN analízis során kapott időállandók és amplitudók spektrumai

A 61. összefoglaló ábrát úgy is értelmezhetjük, hogy a kinetikai elemzések során tehát öt független komponenssel lehet pontosan leírni a FAD fluoreszcencia kinetikáját vízben. Alaposabban tanulmányozva az amplitudó spektrumokat látható, hogy a leggyorsabb komponens ( $\sim 500$ fs, piros vonal) amplitudója speciális hullámhossz-függést mutat: alacsony hullámhosszokon pozitív, míg $560 \mathrm{~nm}$ felett negatív értékü. A DAS esetén egy ilyen tipikus szerkezet arra utal, hogy a mögöttes folyamat kapcsolatban lehet a fluoreszcens kromofórok körüli vízmolekulák szolvatációs dinamikájával [161]. Ez az értelmezés jó egyezést mutat a komponens $\sim 500$ fs-os élettartamával. Az irodalom alapján a szolvatációs válaszidő 800 fs körüli, amely a diffúz mozgást jellemzi vízben [162]. A 800 fs-os élettartam és az alacsonyabb hullámhosszak felé eltolódott spektrum is a szolvatációs dinamikának tulajdonítható egy korábbi tanulmány alapján [55].

A többi négy ( 2 ps, 10 ps, 80 ps és 3 ns) komponens amplitúdó spektruma igen hasonló egymáshoz és a FAD publikált fluoreszcencia spektrumához [56]. Az irodalomban általános az egyetértés, hogy a ns körüli életidővel rendelkező komponens a FAD nyitott, a pikoszekundumos időtartományba eső komponensek pedig az összehajtott konformációra jellemzőek, ahol a közelbe kerülő ADP csoport kioltja a flavin fluoreszcenciáját [55, 56, 163]. 
Bár az egyes publikációkban fellelhetőek az általunk megfigyelt időállandókhoz hasonló értékek, ezek általában egy-egy szük időablakban végrehajtott mérések eredményei. Az általunk elsőként alkalmazott széles idő- és spektrális tartományban végrehajtott, és a BPDNmódszerrel analizált kísérletek egyértelmüen jelzik, hogy a FAD molekulák konformációs állapota heterogénebb, mint azt korábban gondolták. Az eddig csupán ’összehajtott konformáció’-nak nevezett állapot valójában három különböző populációból áll [163].

A továbbiakban összefoglalom az iménti analízis során kapott eredményeinket különböző mikrokörnyezetek esetén. A FAD emissziós maximumánál (530 nm) megnézve a kinetikákat a különböző környezetekben (víz, etanol, dioxán, DMSO, FCC) szembetünő különbségeket kapunk (62. ábra). Mint várható volt, a vízben a fluoreszcencia kioltás gyorsabb, mint a többi szerves oldószerek jelenlétében [55, 163]. Az általunk elöször vizsgált flavocitokrómhoz kötött FAD fluoreszcenciája esetében a kioltása rövidebb időskálán bekövetkezik, mint minden más mikrokörnyezetben.

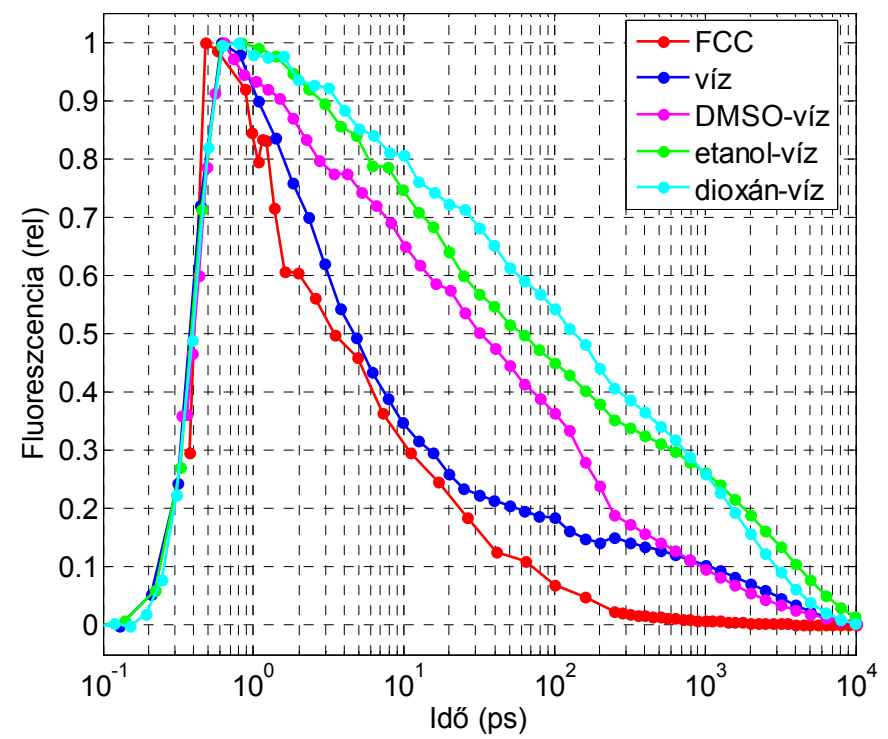

62. ábra - A FAD kinetikája különböző mikrokörnyezetekben 530 nm-en

A 62. ábrán feltüntetett kinetikákhoz tartozó BPDN analízisek eredményeit a 63. ábrán mutatom be (a femtoszekundumos komponenst nem tüntettem fel). Látható, hogy a különböző oldószerekhez tartozó időállandók pozíciójában fellelhető valamelyes eltolódás, amely az oldószereknek a fluoreszcenciára való direkt kölcsönhatásával magyarázható. A lényeges különbségek azonban elsősorban az amplitúdókban figyelhetők meg, ami az egyes konformációk populációjáról szolgáltat információt. Mint várható volt, dioxán, etanol és 
DMSO jelenléte esetén a lassabb, nyitott konformációjú komponensek dominálnak, víz és FCC esetében pedig a gyorsabbak vannak túlsúlyban. Érdekes eredmény, hogy FCC esetében a kinetika egyáltalán nem tartalmaz 1-10 ns-os komponenst. Ez annál inkább meglepő, mivel az 55. $b$ ábra tanúsága szerint az FCC-hez kötött FAD molekula alapvetően nyitott konformációjú. Feltehető tehát, hogy a gyors komponenseket eredményező intenzív kioltás valamely aminosav oldalláncok által okozott direkt perturbáció eredménye. Ez a jövőben lehetőséget nyújt a különböző környezeti hatásoknak kitett fehérjében lejátszódó finom szerkezeti változások követésére.

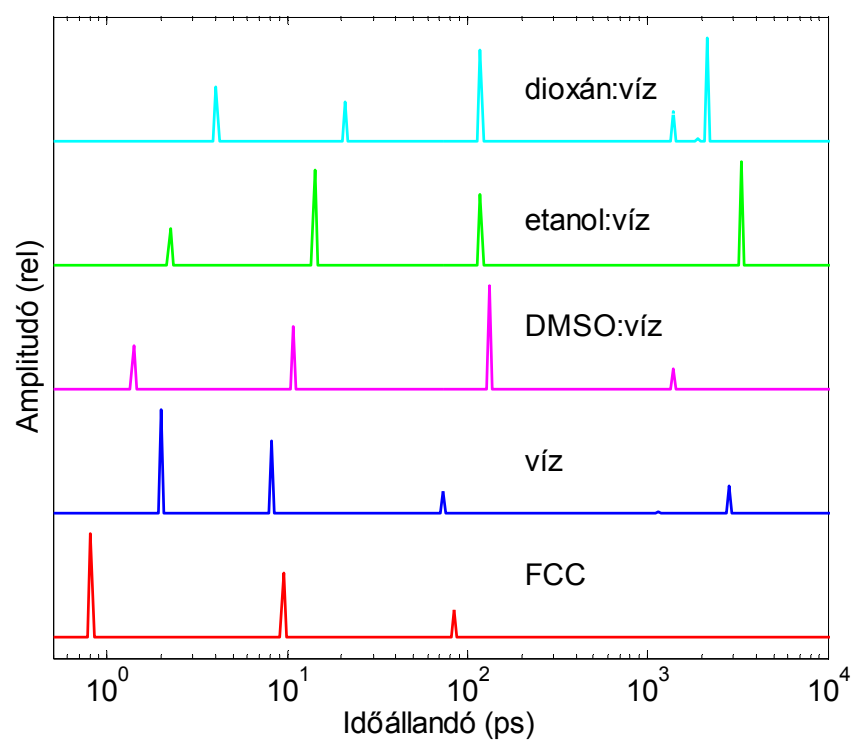

63. ábra - A FAD 530 nm-en mért fluoreszcencia kinetikájának időállandó eloszlása különböző mikrokörnyezetekben

\subsection{3. ÖSSZEFOGLALÁS}

Részt vettem egy femtoszekundumos időfelbontású komplex fluoreszcencia kinetikai mérőrendszer megépítésében és kalibrálásában. Megmértem a FAD fluoreszcencia kinetikáját széles idő- és spektrális tartományon vízben, víz-dioxán, víz-etanol, víz-DMSO oldatokban, valamint fehérjéhez (flavocitokrómhoz) kötve, amely segít megérteni a koenzim intra- és extramolekuláris kölcsönhatásait. Méréseimet egy-foton számláló, illetve a szubpikoszekundumos időtartományon frekvencia átalakítási technikákon alapuló módszerekkel végeztem. A kétféle elrendezés teljes spektrális és időablakbeli összefésülése után egy új kiértékelési algoritmust (Basis Pursuit Denoising) először alkalmazva meghatároztam a FAD időállandóit különböző mikrokörnyezetekben. Megállapítottam, hogy 
oldatok esetében a FAD fluoreszcencia lecsengés négy komponenssel jellemezhető, amellyek egy nyitott és három különböző zárt konformációnak tulajdonítható. Jellemeztem az egyes konformációk populációját a különböző oldószerekben. Ezeken túl vízben a szolvatációs dinamikára utaló 500 fs-os időállandót is sikerült kimutatnom. Az általam elsőként tanulmányozott FCC fluoreszcencia kinetika minden más környezetnél nagyobb mértékü kioltást mutatott, ami a kromofórnak az aminosav oldalláncokkal való erős kölcsönhatására utal. A széles idö- és spekrtális tartományban végzett és új, igen hatékony módszerrel kiértékelt kísérletek a FAD fluoreszcencia mechanizmusának minden eddiginél komplexebb leírását eredményezték [129].

3. tézispont: Részt vettem egy femtoszekundumos időfelbontású komplex fluoreszcencia kinetikai mérőrendszer megépítésében és kalibrálásában. Megmértem a FAD fluoreszcencia kinetikáját széles idő- és spektrális tartományon vízben, víz-dioxán, vízetanol, víz-DMSO oldatokban, valamint flavocitokrómhoz kötve, amely segít megérteni a koenzim intra- és extramolekuláris kölcsönhatásait. Egy új kiértékelési algoritmust (Basis Pursuit Denoising) először alkalmazva megállapítottam, hogy oldatok esetében a FAD fluoreszcencia lecsengése négy komponenssel jellemezhető, amelyek egy nyitott és három különböző zárt konformációnak tulajdoníthatók. Ezeken túl vízben a szolvatációs dinamikára utaló 500 fs-os időállandót is sikerült kimutatnom. Az általam elsőként tanulmányozott flavocitokróm C fluoreszcencia kinetika minden más környezetnél nagyobb mértékü kioltást mutatott, ami a kromofórnak az aminosav oldalláncokkal való erős kölcsönhatására utal. A széles idő- és spektrális tartományban végzett és új, igen hatékony módszerrel kiértékelt kísérletek a FAD fluoreszcencia mechanizmusának minden eddiginél komplexebb leírását eredményezték. 


\subsection{A NADH ABSZORPCIÓ KINETIKÁJÁNAK MÉRÉSE NYITOTT ÉS ZÁRT KONFORMÁCIÓBAN}

Az alábbi fejezetben bemutatom a NADH statikus abszorpciós és fluoreszcenca spektrum mérésének eredményét, majd részletezem a tranziens abszorpciós mérések eredményét különböző koncentrációjú metanol környezetekben. Végül bemutatom a kinetikák illesztésének eredményeit és összegzem munkám.

\subsubsection{STATIKUS ABSZORPCIÓ ÉS FLUORESZCENCIA MÉRÉSEK}

$\mathrm{Az}$ abszorpciókinetikai mérések előtt és után minden esetben mértem abszorpciós spektrumokat, ellenőrizve ezzel a minta stabilitását. A 64. ábrán látható, hogy a mérés előtti (fekete görbe) és utáni kontroll (piros) görbe teljesen megegyezik, a pumpa-próba mérésnél használt minta pedig csak nagyon kis mértékben tér el (zöld), ami az irodalom alapján még elfogadható [60]. A különbséget a pumpáló UV fény által okozott direkt fotodegradáció vagy az abszorpció folytán fellépő magasabb hömérsékleten bekövetkező bomlás okozhatta.

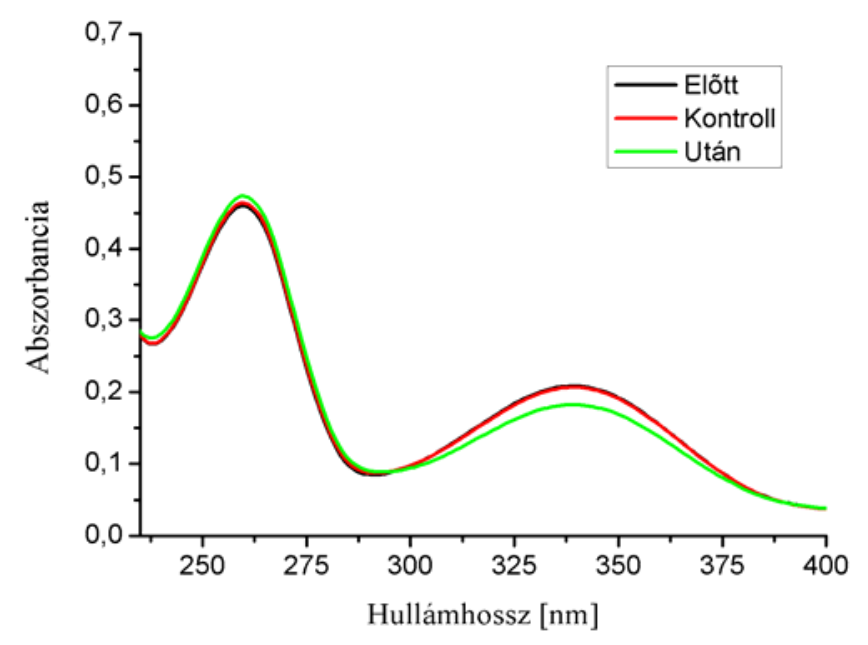

64. ábra - A NADH abszorpciós spektruma

A fluoreszcencia spektrumokat egy standard fluoriméterrel mértem meg különböző $(0,25,50$, 70 és $80 \%$ ) metanol-koncentráció értékeknél 266 nm hullámhosszú gerjesztést alkalmazva (65. ábra). Látható, hogy a növekvő metanol-koncentráció mellett a fluoreszcencia intenzitása egyre csökken. Ez várható volt, hiszen a NADH metanolban nyitott konformációban van, tehát az adenin csoport térben eltávolodik a fluoreszkáló nikotinamid csoporttól (2.1.2.2. 
alfejezet, 7. ábra), vagyis az energia transzfer esélye lecsökken a két csoport között. A 65. ábrán 532 nm-nél a keskeny, intenzív csúcs a spektrumban csak melléktermék, a gerjesztő fény második rendbeli diffrakcióját nem lehetett a gyári szürőkkel eliminálni.

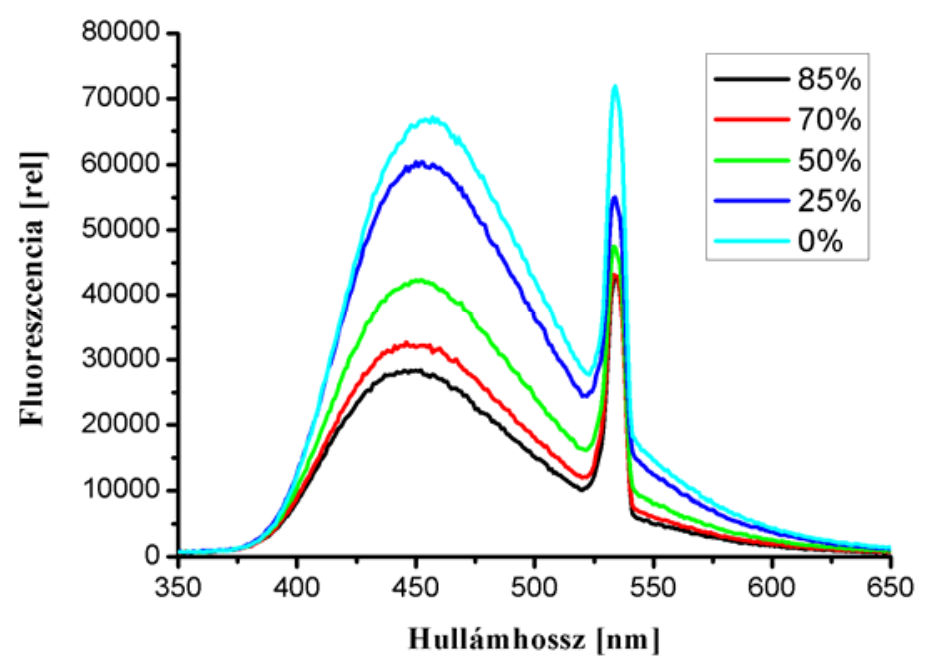

65. ábra - A NADH steady-state fluoreszcenciája 266 nm gerjesztés mellett

A fluoreszcencia $\mathrm{MeOH}$-függését még jobban szemlélteti a 66. ábra, amely esetén a fluoreszcencia gerjesztési spektrumokat is bemutatom, $470 \mathrm{~nm}$ megfigyelési hullámhossz mellett az imént megadott metanol koncentrációk függvényében.

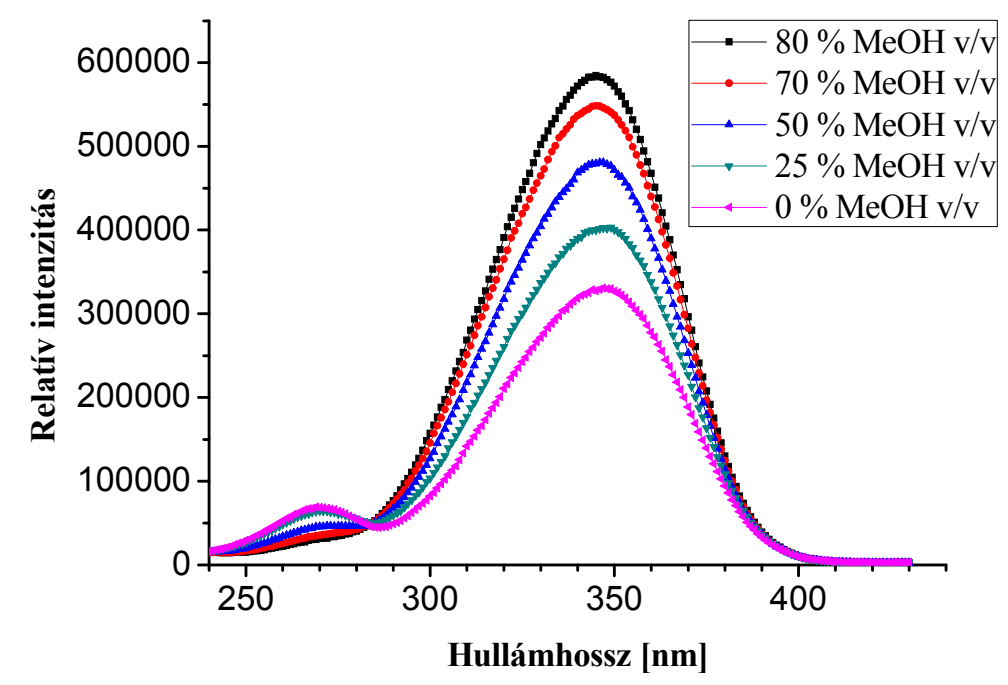

66. ábra - A NADH fluoreszcencia gerjesztési spektruma 470 nm-en különböző metanol-koncentrációk esetén 
Az így kapott abszorpciós maximumok intenzitásának arányából kiszámolható a két konformációs állapot közötti energia transzfer képessége (RPET, relative probability for energy transfer)[59]:

$$
\text { RPET }=\frac{I_{N}-I}{I_{N}-I_{D}},
$$

ahol $I$ a fluoreszcencia intenzitás, $I_{N}$ a natív (zárt forma), $I_{D}$ pedig a denaturált (nyitott forma) NADH fluoreszcencia gerjesztési intenzitása. Mint ahogy a 67 ábrán látható, $50 \%$ metanol koncentráció alatt még képes energia átadásra az adenin csoport, 80 \% esetén azonban már egyáltalán nem. Ezeket az előismereteket felhasználva a NADH tranziens abszorbcióját 0, 50, 70 és $80 \%$ metanol koncentrációkon érdemes mérni, hogy jól lássuk a konformációk közti különbségeket.

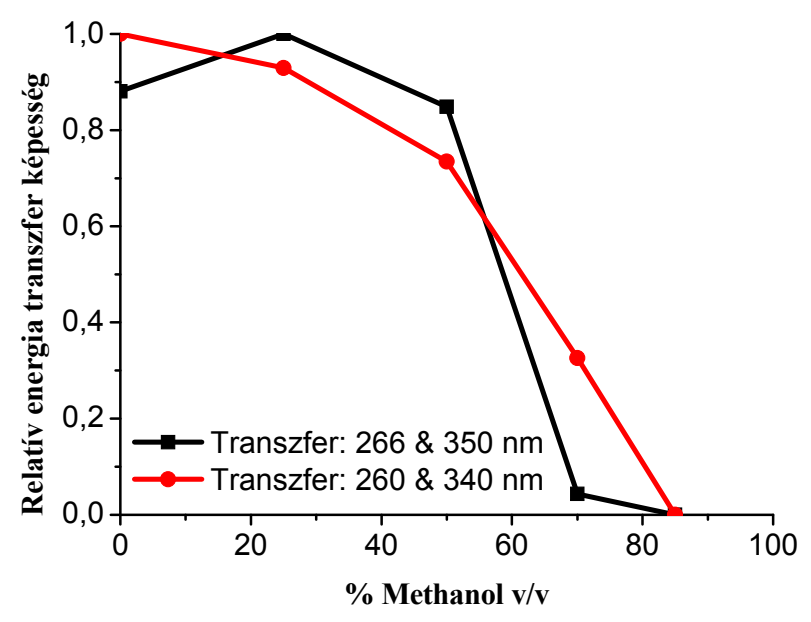

67. ábra - A NADH energiatranszfer képessége különböző metanol koncentrációknál

\subsubsection{TRANZIENS ABSZORPCIÓS MÉRÉSEK}

Pumpa-próba méréseim során először a NADH minták abszorpció változását mértem meg adott metanol koncentráción, majd ezt követően az azonos metanol koncentrációjú PIPES puffert. Az abszorpciós spektrumokat mind a NADH minták, mind pedig a pufferek esetében a -300 fs és 4,5 ns közötti késleltetés tartományon belül négy különböző metanol koncentráción, egyenként 40-szer mértem meg, majd ezeket átlagoltam. Összesen 135 késleltetésnél vettem fel a tranziens spektrumokat, az 1 ps alatti időtartományban lineáris, míg az 1 ps feletti tartományban logaritmikus lépésközzel haladtam. A 68. ábrán a szaggatott, kék 
vonal egy mérés eredményét mutatja metanol jelenléte nélküli NADH mintánál, míg a folytonos, piros görbe a 40 mérés átlagát szemlélteti. (A kék görbén $10^{5}$ fs értéknél fellépö egy pontból álló csúcs a mintában fellépő búborékképződés eredménye. Az ilyen típusú hibákat az átlagolás előtt elimináltam.)

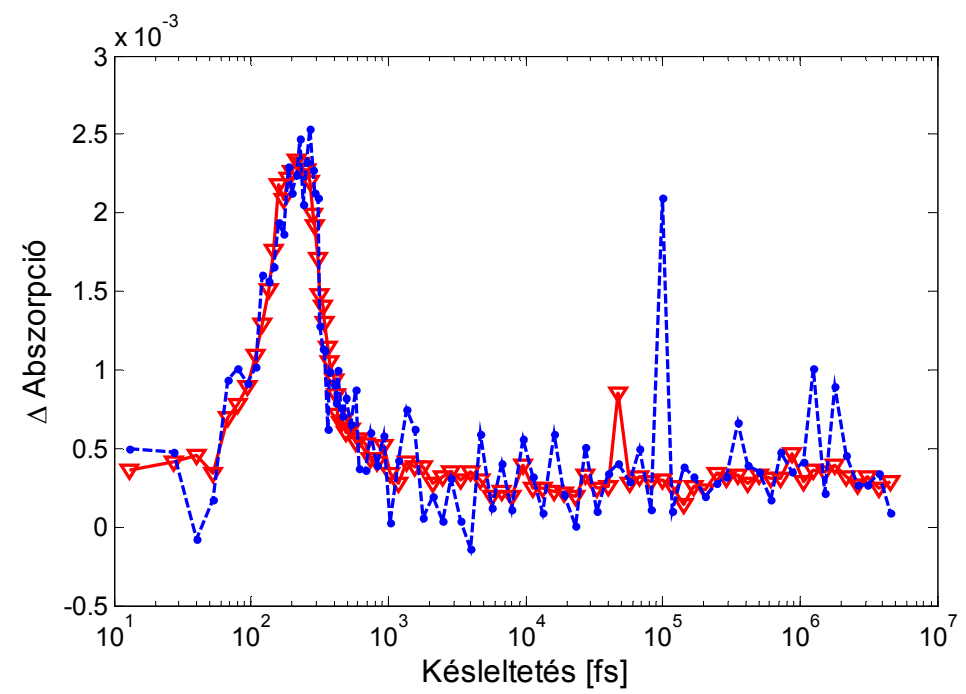

68. ábra - Metanol jelenléte nélkül a NADH 370 nm-nél mért abszorpcióváltozása a késleltetés függvényében (kék, szaggatott vonal: egy mérés; piros, folytonos vonal: 40 mérés átlaga)

Mivel előfordult esetenként a minta buborékolása (például 68. ábra, $10^{5}$ fs értéknél, kék görbe), ami hirtelen, 1 pixelnyi kiugrást jelentett az adatsorokban, ezért az átlagolások elött egyesével végignéztem a méréseket. Ahol 1 pixelnyi hirtelen abszorpcióváltozást találtam, ott az előző vagy következő buborékmentes mérés megfelelő pixelértékével kicseréltem a „hibás” pixelhez tartozó értéket. Majd e buborékkorekció elvégzése után hajtottam végre a mérések átlagolását.

A puffer és a minta kinetikáit a 69. ábrán mutatom be 390 nm-nél. Jól látható, hogy az UV impulzusok nem károsították sem a puffert, sem pedig a NADH mintákat. A 40 mérés ideje nagyjából négy óra volt, amely során nem tapasztalható időfüggő komponens. 

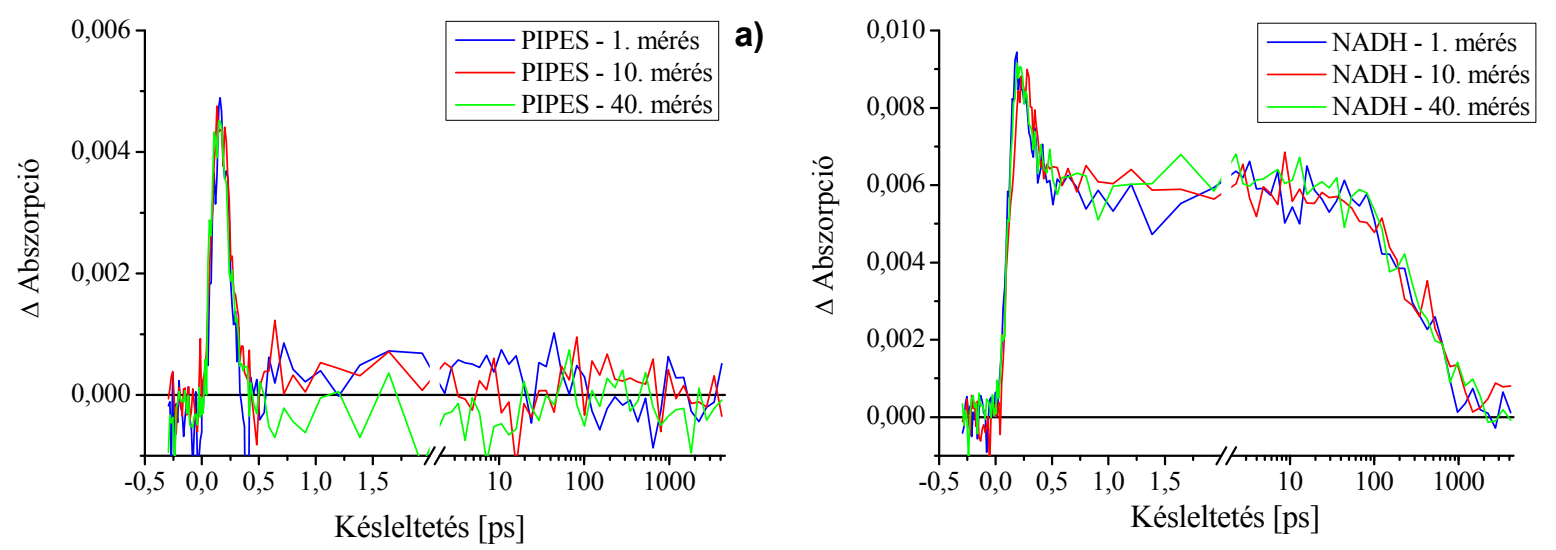

b)

69. ábra - (a) A PIPES puffer és a (b) NADH minta kinetikája 390 nm-nél. Kékkel az 1. mérés, pirossal a 10. mérés, zölddel pedig a 40. mérés eredménye látható.

Az adatok kiértékelését Scilab és Matlab programokkal végeztem a Kisérleti anyagok és módszerek címü fejezetben leírtak alapján. A felvett spektrumok már spektrálisan kalibrálva voltak a beolvasáskor. Így elöször a csörpkorrekciót hajtottam végre. Mivel a vizsgált NADH mintát különböző metanol koncentrációjú pufferben mértem, így minden egyes mintánál megmértem a hozzá tartozó oldószert is.

E korrekció után az abszorpció változás nulla szintjének keresése, vagyis a háttér korrekciója következett. Itt a negatív ( $\mathrm{t}=0$ elötti) időtartománybeli késleltetéseknél a mérésekből egy átlagos hátteret számoltam, amit nulla abszorpció-változásnak definiáltam, majd minden egyes képen végrehajtottam ezt a háttérkorrekciót. Vagyis ezen két korrekcióval mind a méréseim időtengelyét, mind pedig az abszorpciós tengelyét megfelelően kalibráltam.

A 4.4.3 fejezetben leírt módon feldolgozott (csörp- és háttérkorrekció, valamint zajszürés) abszorpciókinetikákat a 70. ábra mutatja (vö. a 36. ábrán látható korrigálatlan adatokkal). 


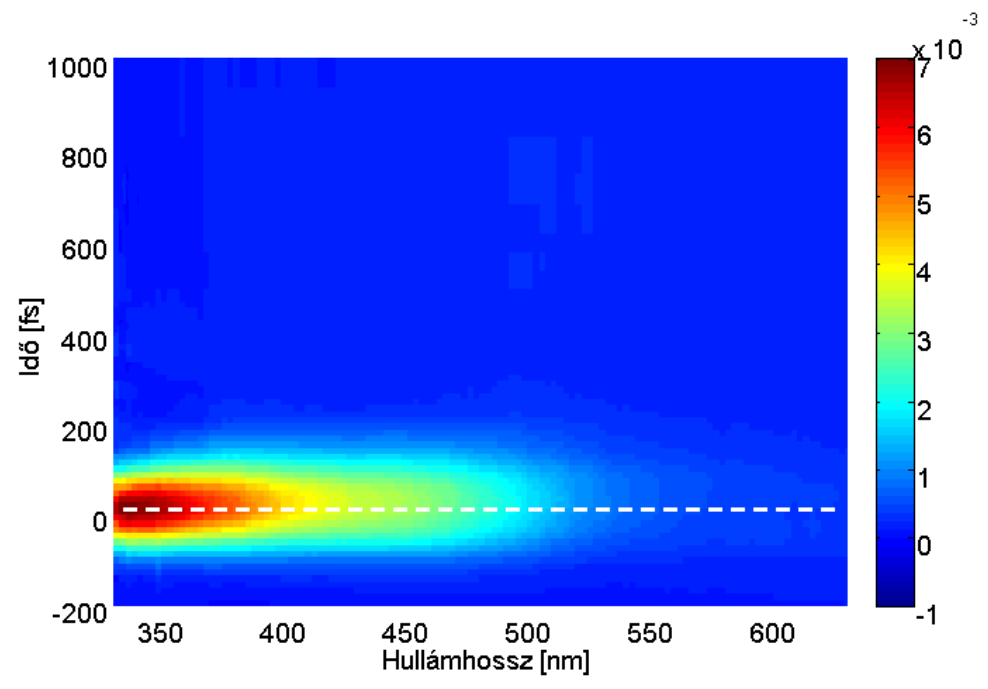

70. ábra - A PIPES puffer időbontott TPA spektruma $80 \%$ metanol jelenléte esetén csörp- és háttérkorrekciót, valamint zajszürést követően

A kiértékeléseim utolsó lépése az oldószer-korrekció volt. A (4.15) illesztést és kivonást elvégezve, az oldószerkorrekció utáni időbontott spektrumokat a 71 . ábrán mutatom be 0,50 , 70 és $80 \%$ metanol koncentrációknál.
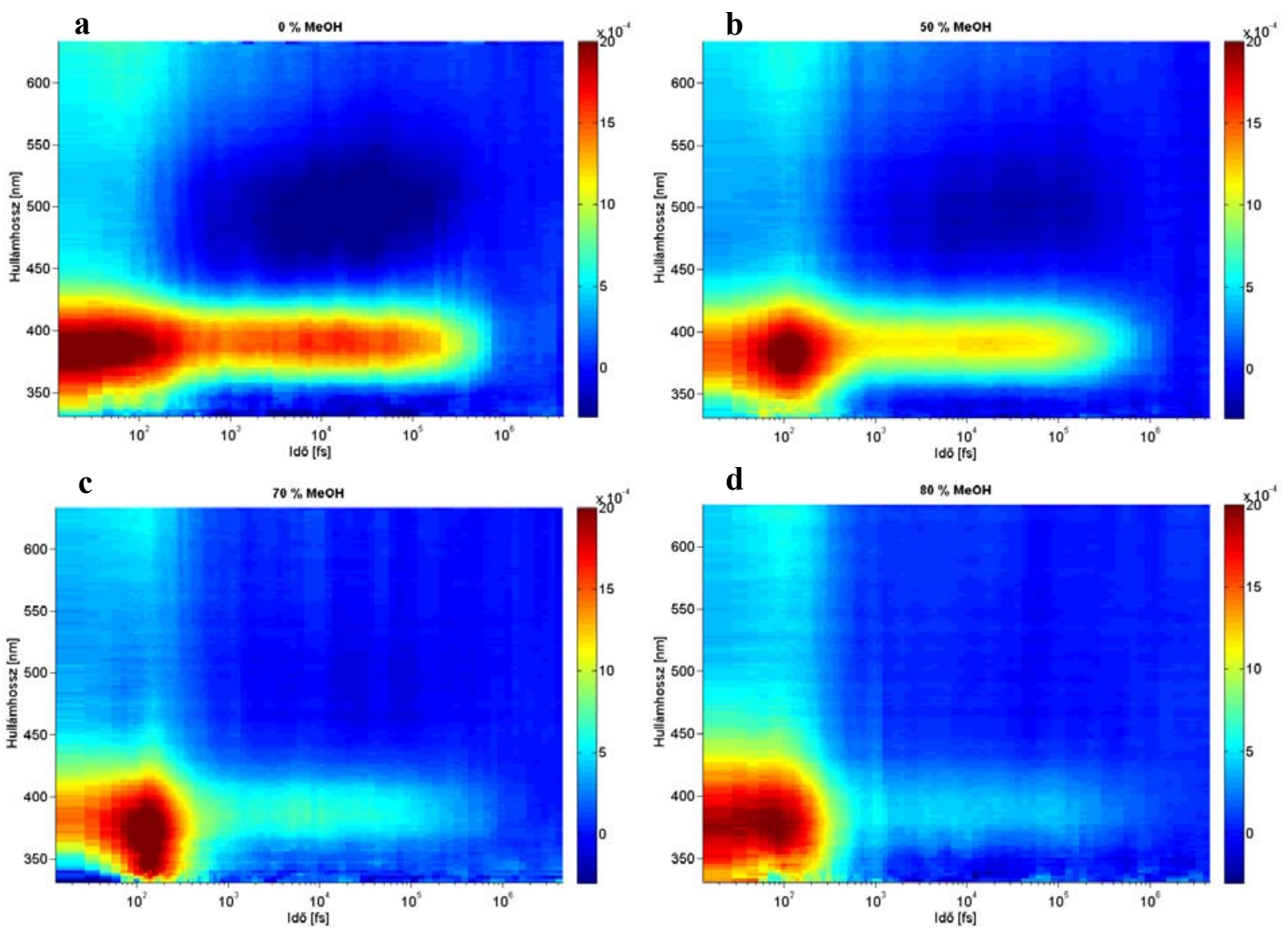

71. ábra - A NADH időbontott spektrumai (a) 0, (b) 50, (c) 70 és (d) $80 \%$ metanol koncentrációk esetén 
A színkódolás a 71. $a-d$ ábrákon megegyezik: a piros a pozitív, sötétkék a negatív abszorpcióváltozásnak felel meg. A metanolos $(a)$ és metanolmentes $(d)$ esetben szembetűnő a különbség: a 470-550 nm közötti SE, valamint a 370 nm központi hullámhosszon látható ESA $80^{\circ} \%$ metanol koncentráción már teljesen eltünik. Ezeket az eltéréseket a tranziensekben a jobb átláthatóság miatt a $370 \mathrm{~nm}$ (72. ábra) és $520 \mathrm{~nm}$ (73. ábra) hullámhosszakon különkülön is bemutatom különböző MeOH koncentrációk mellett. Külön ábrázoltam az első 1 psos időablakot lineáris skálán, és logaritmikus skálán az 1 ps utáni tartományt.
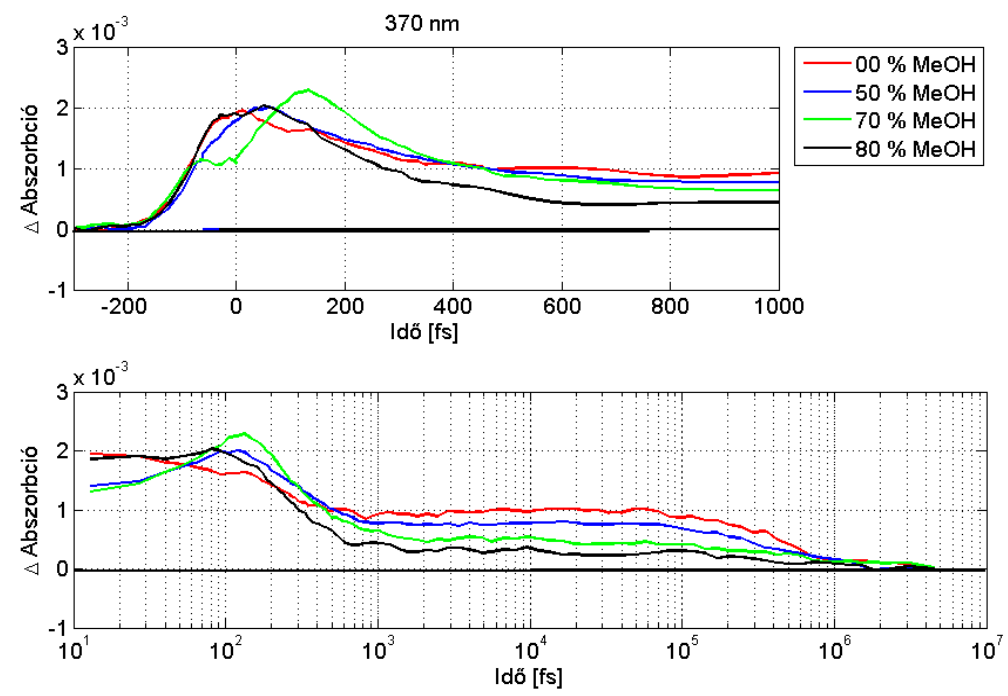

72. ábra - A NADH időfüggő abszorpció változása 370 nm-en
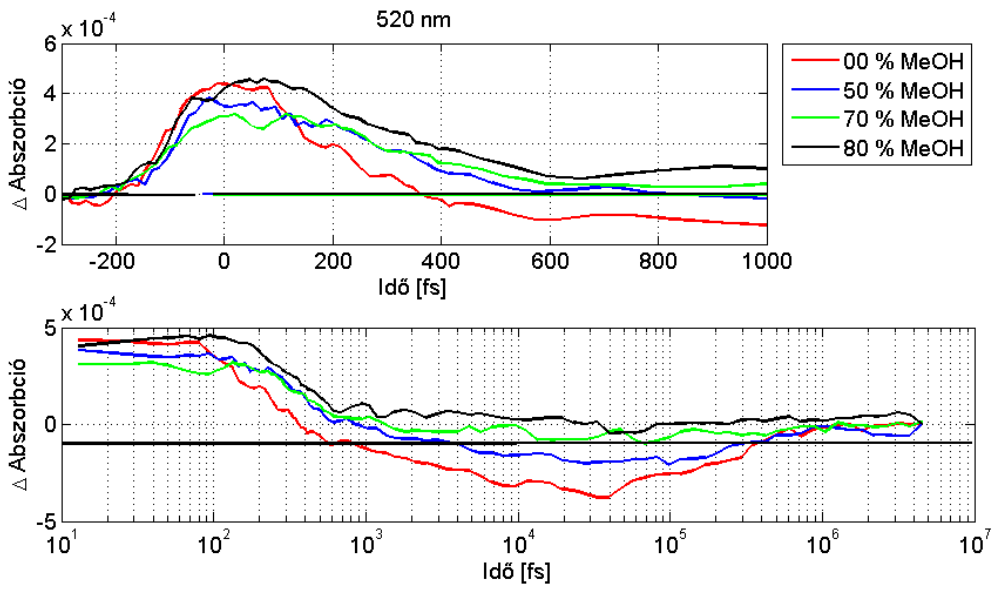

73. ábra - A NADH időfüggő abszorpció változása 520 nm-en

Az adenin csoport gerjesztését követő abszorpció-változás spektrumának időfejlődése látható a 74. ábrán, metanol jelenlétében (a) illetve hiányában (b). Mindkét esetben abszorpció- 
növekedés tapasztalható a 350-450 nm-es tartományban. Ez a gerjesztett állapotbeli abszorpció a nikotinamid csoport abszorpciós sávjába esik, és meghaladja a megfelelő alapállapotú kifakulást. Amint lentebb látható, ez a sáv mind az adenin, mind a nikotinamid ESA-jából adódik, a korábban kialakuló, adeninhez kapcsolható spektrum ( $0 \%$ metanol) abszorpció-változása valamivel nagyobb. További, az adenintől származó ESA figyelhető meg az $500 \mathrm{~nm}$ feletti tartományban, amely igen gyorsan $(<2$ ps) csökken, bár tiszta vízben valamivel nagyobb időállandóval ( 10 ps).
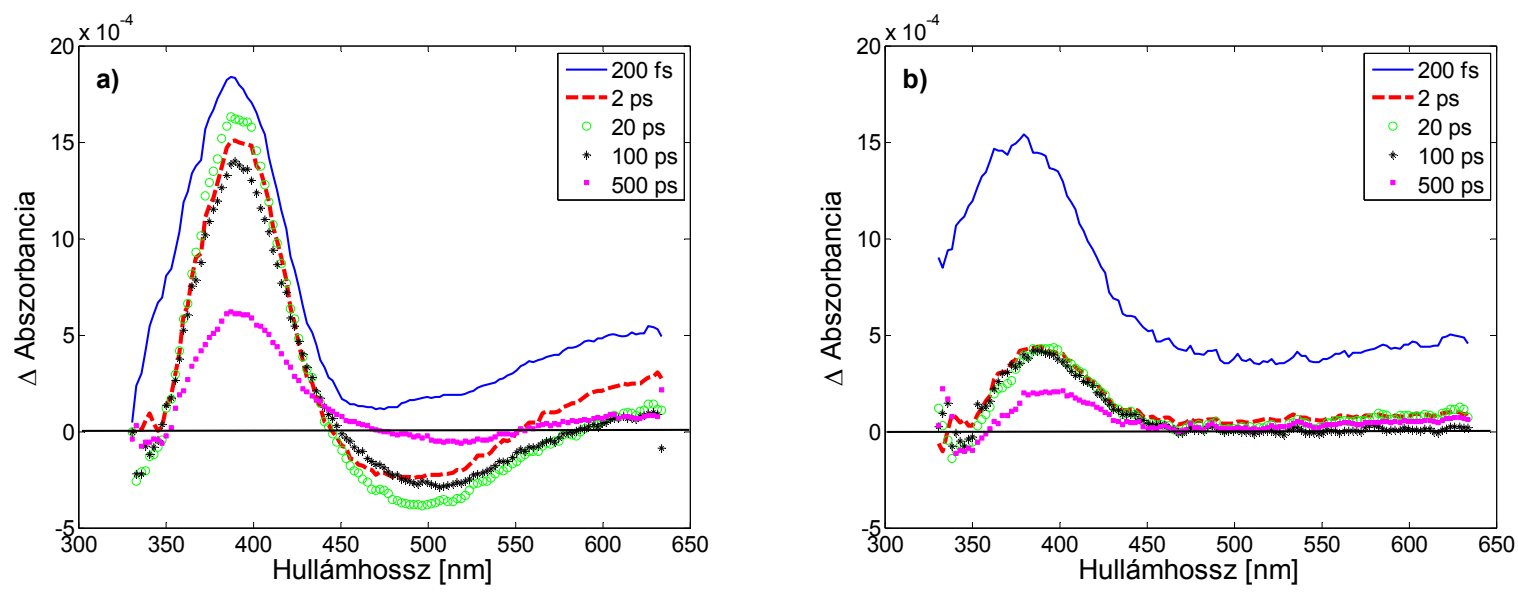

74. ábra - A NADH abszorpciós differenciaspektrumának időbeli fejlődése $0 \%$ (a) és $80 \%$ (b) metanol esetében

Ennek a vörösbeli ESA-lecsengésnek a velejárója egy, a 450-570 nm-es tartományon megjelenő negatív abszorbció, ami tiszta vízben figyelhető meg legjobban. E negatív sáv maximuma egybe esik a NADH emissziós maximumával, ezért ezt indukált emissziónak tulajdoníthatjuk. A gerjesztés után 200 fs-mal mért spektrumok mindegyik metanolkoncentráció esetén hasonlóak, de a metanol nélküli mintában a 2 és 100 ps közti spektrumok esetén, föleg az előbb említett negatív abszorpciós tartományban figyelhető meg eltérés. Ez alátámasztja a nyitott konformációs $(>80 \% \mathrm{MeOH}$ koncentráció feletti) állapotbeli fluoreszcencia-kioltást.

\subsubsection{A KINETIKÁK ILLESZTÉSE ÉS ÉRTELMEZÉSE}

A 380 és 520 nm-en mért kinetikák (75. ábra) jelentősen különböznek a két esetben: 80\% metanolban néhány ps alatt lecsengenek, míg vízben egy második, növekvő fázist találunk a 10 ps-os időtartományban. Ez a különbség a spektrumok időfejlődésén is jól látható (ld. 7274. ábrákon). 

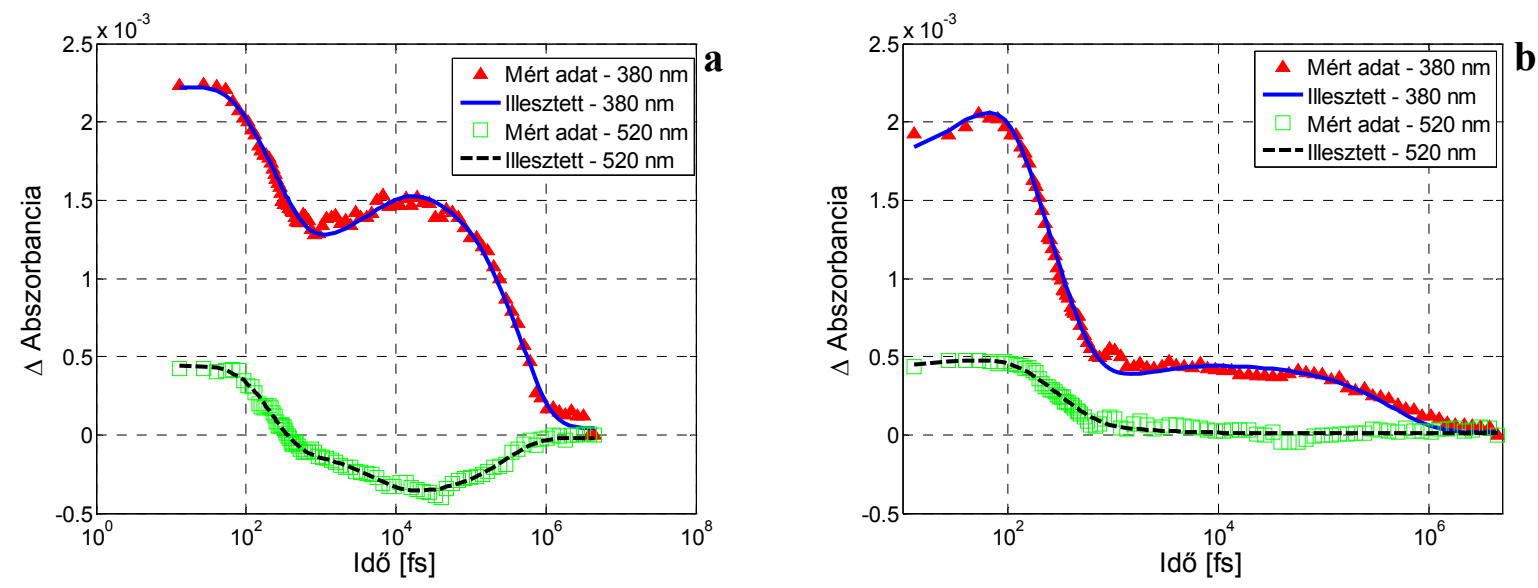

75. ábra - A NADH transiens abszorpciójának időfejlődése $0 \%$ (a) és 80 \% (b) metanol esetében

Azt találtam, hogy a kinetikák hullámhossztól és metanol-koncentrációtól függetlenül három exponenciálissal illeszthetők. A leggyorsabb, 250 fs-os időállandójú komponens metanol jelenlététől függetlenül minden esetben jelentkezik. Ez az adenin csoport gerjesztett állapotú abszorpciójának tulajdonítható és az adeninhez kapcsolható vörös ESA lecsengését jellemzi a $\lambda>600 \mathrm{~nm}$-es tartományban. Metanol nélkül további két komponens (3, ill. 350 ps időállandóval) jelentkezik relatíve nagy súllyal, mind a 380, mind az 520 nm-es kinetikák esetén. A kb. 3 ps-os komponens szintén megfigyelhető a vörös ESA lecsengésében. Ezek alapján megállapíthatjuk, hogy vízben az adenintől a nikotinamid felé energia-átadás történik, amelyet a nikotinamid fluoreszcens gerjesztett állapotának lecsengése követ 350 ps-on belül. Metanol jelenlétében a gyengébb hatásfokú energia-átadásnak megfelelően a nikotinamidhoz kapcsolható, gyenge ESA és stimulált emisszió jelentkezik 3 ps-os időállandóval. Mindezt a 6. táblázatban összegzem. 


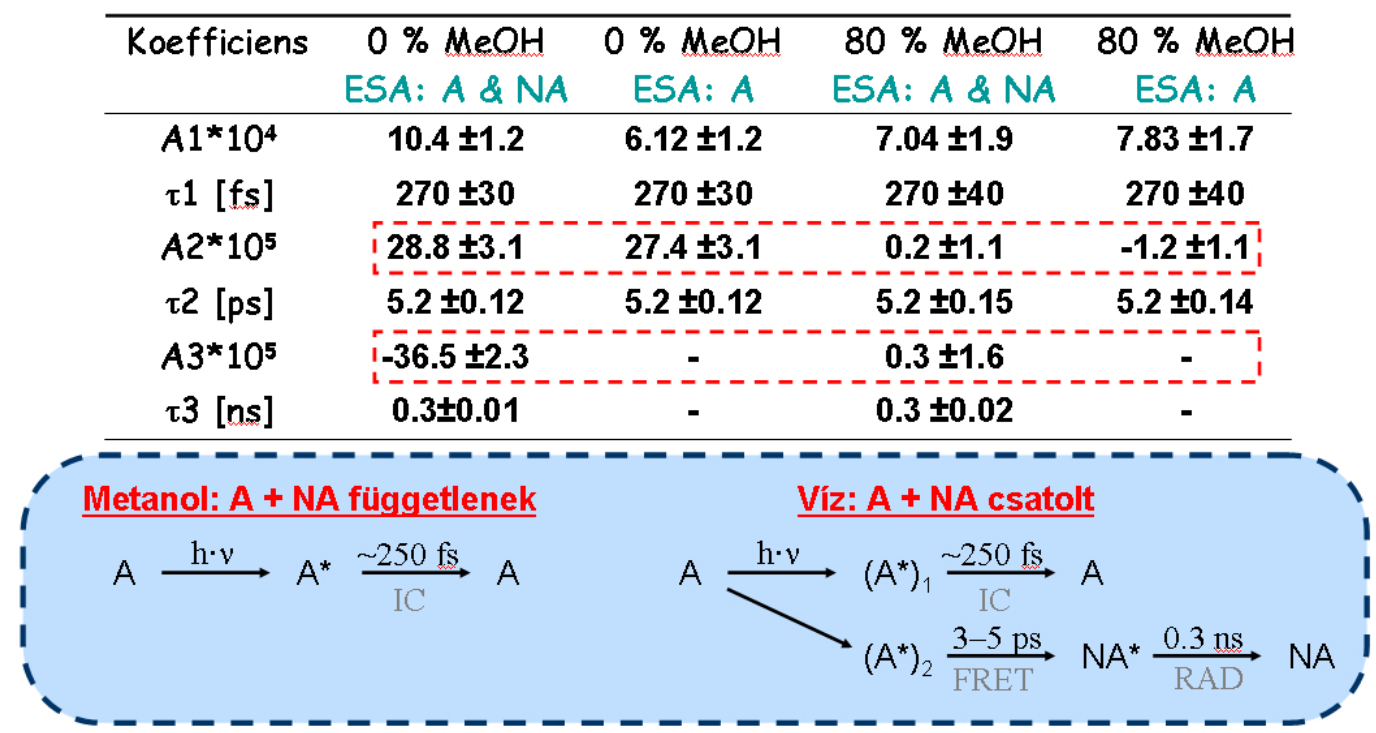

6. táblázat - A NADH nyitott és zárt konformációs állapotának időállandói és amplitudói, valamint a két konformációs állapot lehetséges müködési mechanizmusa

(A: Adenin csoport; NA: nikotinamid csoport)

Összefoglalásként megállapíthatjuk, hogy az adenin gerjesztett állapotának lecsengése kétfázisú folyamat, és csak a lassabb, 3 ps-os időállandóval jellemezhető folyamat felelös a nikotinamid gyürü gerjesztéséért. Ez csak abban az esetben lehetséges, ha tiszta vízben legalább két konformációs állapot (nyitott, ill. zárt) együtt van jelen. Metanol hozzáadásával ez a termodinamikai egyensúly a nyitott konformáció felé tolódik el, amely a FRET gyengülését eredményezi a két csoport térbeli távolodása miatt.

\subsection{4. ÖSSZEFOGLALÁS}

Femtoszekundumos pumpa-próba módszerrel megmértem a NADH tranziens abszorpcióját 0 , 50, 70 és $80 \%$ metanol koncentrációkon. A mért adatok globális analízisét használva meghatároztam a különböző metanol koncentrációkhoz tartozó időrátákat, ezáltal a molekula szerkezeti változására (nyitott és zárt konformáció) vonatkozó 250 fs, 3 ps és 0.35 ns időállandókat sikerült megadnom. Ezek ismeretében a molekula működését az alábbiakban foglalom össze. Az általam mért leggyorsabb időállandó 250 fs - ami megjelenik a metanol jelenlétében és hiányában egyaránt - az adenin csoport gerjesztett állapoti abszorpciójának (ESA, excited state absorption) tulajdonítható. A második és a harmadik komponens (3 ps és 
350 ps) 380 és $520 \mathrm{~nm}$-en a metanol-mentes minta esetében egyre nagyobb hangsúlyt, azaz amplitúdó értéket kap. Ezek a megfigyelések azt mutatják, hogy vízben az energiaátadás az adenintől a nikotinamidhoz 3 ps időállandóval jellemezhető, majd a nikotinamid csoport gerjesztett állapotból indukált emisszióval (SE, stimulated emission) 350 ps alatt tér vissza alapállapotba. Metanol jelenlétében, a nikotinamid csoporthoz tartozó ESA és SE időállandója sokkal alacsonyabb amplitudójú (közel nulla), ami összhangban van a várt energia-átadás csökkenésével nyitott konformációban, hisz a két csoport térben eltávolodik egymástól.

4. tézispont: Femtoszekundumos pumpa-próba módszerrel megmértem a NADH tranziens abszorpcióját 0, 50, 70 és $80 \%$ metanol koncentrációkon, ami a molekula különböző konformációs állapotairól ad információt. A mért adatok globális analízise eredményeként az abszorpció kinetikák 250 fs, 3 ps és 350 ps időállandókkal voltak jellemezhetőek. A 250 fs-os időállandó az adenin csoport gerjesztett állapoti abszorpciójának tulajdonítható. A második és a harmadik komponens metanol-mentes minta esetében rendelkezik nagy amplitúdó értékkel. Ezek a megfigyelések azt mutatják, hogy vízben az energiaátadás az adenintől a nikotinamidhoz 3 ps időállandóval jellemezhető, majd a nikotinamid csoport a gerjesztett állapotból 350 ps alatt tér vissza alapállapotba. Növekvő metanol koncentrációval az energiaátadást biztosító zárt konformáció populációja egyre csökken, ami a fenti lassú komponensek súlyának csökkenéséhez vezet. 


\section{6. ÖSSZEFOGLALÁS}

\subsection{MAGYAR NYELVÜ TÉZISSZERŰ ÖSSZEFOGLALÓ}

Munkám során ultrarövid, nJ-mJ energiájú lézerimpulzusok spektroszkópiai alkalmazásával foglalkoztam. Eredményeim két fó kutatási irányvonalat céloztak meg. Az egyik a bakteriorodopszin membránfehérje törésmutatójának vizsgálata és lehetséges alkalmazása az optikai távközlésben. A másik irányzat pedig a flavin adenin dinukleotid és a redukált nikotinamid adenin dinukleotid koenzimek ultragyors időbontott spektroszkópiai vizsgálata, mivel e koenzimek a sejtek energiatermelő folyamataiban (energiatranszport láncban) vesznek részt, így vizsgálatukon keresztül többek között a sejtek metabolikus állapota is tanulmányozható. Tudományos eredményeimet az alábbi tézispontokban foglalom össze:

1. A minimális deviáció szögének méréséböl meghatároztam a törésmutató értékeket, ahol a levegő diszperzióját az aktuális laboratóriumi állapotra nagy pontossággal kiszámoltam a hőmérséklet- és nyomásfüggő Sellmeier-egyenletből. Először meghatároztam a TRIS puffer törésmutatóját, majd a bR szuszpenziók törésmutatóját különböző koncentrációkon 390-880 nm közti hullámhossztartományon. Elsőként adtam meg a TRIS puffer és a bR szuszpenzió Sellmeier-együtthatóit [J1, C1-C4, K1-K3].

2. Integrált optikai hullámvezető felszínére szárított vékony bR réteget alkalmazva pumpa-próba mérésekkel kimutattam, hogy a bR abszorpciója miatt bekövetkező törésmutató-változás hatására a hullámvezetőbe csatolt vezetett módus rezonanciacsúcsa a gerjesztést követően szubpikoszekundumos idő alatt eltolódik. Mérési eredményeimet összevetettem a bR fotociklusára vonatkozó időállandók értékeivel, amelyek alapján számolással igazoltam, hogy a mért jel intenzitás-változását főként a BR-I átalakulással együtt járó törésmutató-változás dominálja. Az eredmények tisztán mutatják, hogy a bR fotociklusának $\mathrm{BR} \rightarrow \mathrm{I}$ átmenete alkalmazható ultragyors, tisztán optikai elven müködő fénykapcsolásra [J2, C5-C9, C11-C16, C20, K4, K5].

3. Részt vettem egy femtoszekundumos időfelbontású komplex fluoreszcencia kinetikai mérőrendszer megépítésében és kalibrálásában. Megmértem a FAD fluoreszcencia kinetikáját széles idő- és spektrális tartományon vízben, víz-dioxán, víz-etanol, víz-DMSO oldatokban, valamint flavocitokrómhoz kötve, amely segít megérteni a koenzim intra- és extramolekuláris kölcsönhatásait. Egy új kiértékelési algoritmust (Basis Pursuit Denoising) 
először alkalmazva megállapítottam, hogy oldatok esetében a FAD fluoreszcencia lecsengése négy komponenssel jellemezhető, amelyek egy nyitott és három különböző zárt konformációnak tulajdoníthatók. Ezeken túl vízben a szolvatációs dinamikára utaló 500 fsos időállandót is sikerült kimutatnom. Az általam elsőként tanulmányozott flavocitokróm $C$ fluoreszcencia kinetika minden más környezetnél nagyobb mértékű kioltást mutatott, ami a kromofórnak az aminosav oldalláncokkal való erős kölcsönhatására utal. A széles idő- és spektrális tartományban végzett és új, igen hatékony módszerrel kiértékelt kísérletek a FAD fluoreszcencia mechanizmusának minden eddiginél komplexebb leírását eredményezték [J3, J4, C10, C17, C19, C21, K6].

4. Femtoszekundumos pumpa-próba módszerrel megmértem a NADH tranziens abszorpcióját $0,50,70$ és $80 \%$ metanol koncentrációkon, ami a molekula különböző konformációs állapotairól ad információt. A mért adatok globális analízise eredményeként az abszorpció kinetikák 250 fs, 3 ps és 350 ps időállandókkal voltak jellemezhetőek. A 250 fs-os időállandó az adenin csoport gerjesztett állapoti abszorpciójának tulajdonítható. A második és a harmadik komponens metanol-mentes minta esetében rendelkezik nagy amplitúdó értékkel. Ezek a megfigyelések azt mutatják, hogy vízben az energiaátadás az adenintől a nikotinamidhoz 3 ps időállandóval jellemezhető, majd a nikotinamid csoport a gerjesztett állapotból 350 ps alatt tér vissza alapállapotba. Növekvő metanol koncentrációval az energiaátadást biztosító zárt konformáció populációja egyre csökken [J5, C18], ami a fenti lassú komponensek súlyának csökkenéséhez vezet. 


\subsection{ANGOL NYELVÜ ÖSSZEFOGLALÓ}

\section{SUMMARY OF DisSERTATION}

\section{Introduction}

A new dawn of optics has started in 1960, with the development of the first laser. In 1964, invention of mode locking allowed the generation of ultrashort pulses and 20 years later the pulse duration reached 27 fs with the use of prism compressors. Since, the continuous evolution of lasers has contributed to a lot of scientific discoveries in almost all research areas of natural sciences. However, in many applications one needs much more energy than that an oscillator can provide. From the 70's, this demand of high-energy ultrashort pulses led to the intensive research of short-pulse amplification. By using amplified pulses of $10^{10} \mathrm{~W} / \mathrm{cm}^{2}$ intensity we are able to investigate the theoretically foreseen nonlinear effects of light-matter interactions. In the last 15-20 years a lot of new results have emerged in the interdisciplinary fields of femtochemistry and femtobiology and the pioneering work of Ahmed H. Zewail was awarded with the Nobel-prize in chemistry. Nowadays, the pump-probe technique developed by him is a very effective tool in the hands of researchers investigating ultrafast biological and chemical processes.

This thesis deals with the spectroscopic applications of ultrashort laser pulses. In my experiments, either femtosecond pulses of $\mathrm{nJ}$ energy or amplified pulses of several $\mathrm{mJ}$ were used, depending on the requirements of the corresponding experiment.

The thesis is separated into two parts. First, a possible application of the membrane protein bacteriorhodopsin (bR) in optical communication is demonstrated. In the second part, two biologically important coenzymes, flavin adenine dinucleotide (FAD) and the reduced form of nicotinamide adenine dinucleotide (NADH) are investigated by means of femtosecond time-resolved spectroscopy. These coenzymes play a role in the energy producing processes of the cells by converting chemical energy to useful metabolic energy (in the electron transport chain), which provides information about the metabolic state of the cells. 


\section{Scientific objects and goals}

One of the objects of my biophysical investigations is bacteriorhodopsin, a light energy converting protein found in the cell membrane of Halobacterium salinarum, which has been one of the most significant molecules of the biological and biophysical research of the past 30 years. Upon light absorption, the protein pumps a proton across the membrane from the cytoplasm to the extracellular moiety and the generated electrochemical gradient is further used for ATP synthesis. During the proton translocation process the protein undergoes a cyclic change of conformational states with well distinguishable absorption spectra. The consequent light-induced refractive index change offers the possibility of a wide range of applications in photonics, nonlinear optics, and bioelectronics. In spite of bR being used in several optical devices and applications, experimental data on its concentration-dependent refractive index and optical dispersion are not available. Therefore, one of my aims was (1) to measure the concentration-dependent refractive index of bacteriorhodopsin suspensions and to determine its Sellmeier-coefficients in the visible range of the spectrum.

The speed and bandwidth of today's telecommunication components are continuously growing, the desired $1 \mathrm{Tbit} / \mathrm{s}$ trafficking rate is thought to be achieved by using all-optical data processing devices. One of the biggest challenges in integrated optics (IO) is to find new materials of proper nonlinear optical (NLO) properties which can play an active, controlling role in integrated optical circuits. Besides inorganic crystals, materials of biological origin are also considered for use as active elements in IO devices, among which the bacteriorhodopsin has generated the most interest. Due to its favorable NLO properties and mechanical stability, $\mathrm{bR}$ is a promising candidate as an active material in future photonic applications. (2) In order to demonstrate the feasibility of a protein-based integrated optical device, I investigated the subpicosecond $(B R \rightarrow I)$ transition of the protein photocycle by means of ultrafast pump-probe techniques and a waveguide-based photonic structure.

An important part of my research activities conducted at the Institute of Biophysics was the development of a fluorescence kinetic measuring system based on optical frequency up-conversion, by which the fluorescence of different natural and artificial chromophores can be monitored with a good time-resolution in a wide spectral range. Among the most important autofluorescent molecules are the coenzymes FAD and NADH, which play a key role in the redox processes of the molecular respiratory chain. The in vivo fluorescence decay rates of these molecules are often used to characterize healthy and diseased cells and tissues. However, we have very few experimental data about how the individual components (e.g. 
polarity of solvent, $\mathrm{pH}$, etc.) of the cell's micro-environment affect these characteristic rate constants. Comparison of the experimental findings concerning the effects of these parameters with the in vivo results can be important in future medical applications. (3) My aim was to measure the effect of different micro-environments on the fluorescence lifetime of coenzyme FAD on the 100 fs -10 ns timescale. The molecule was investigated both in its free forms in different solvents and when bound to a protein.

The coenzyme NADH has two chromophores (nicotinamide and adenine) between which an efficient FRET (fluorescence resonance energy transfer) process can occur. The efficiency of the energy transfer is strongly dependent on the conformational state of the molecule. (4) In order to deeply understand the intramolecular processes following excitation, I used ultrafast transient absorption measurement techniques to investigate the open and closed conformations of the coenzyme.

\section{Materials and methods}

The experiments were conducted using femtosecond light sources including Ti:sapphire oscillators and chirped pulse amplifiers (CPAs). In the following subsections, I describe the experimental methods and setups used in my work together with the preparation of biological samples.

1. The sample used in the measurement of the concentration dependent refractive index of bR was obtained in the form of suspension from the Institute of Biophysics, Biological Research Centre of HAS. The concentrations between 0 and $80 \mu \mathrm{M}$ were set using $10 \mathrm{mM}$, pH 7.0 Tris(hydroxymethyl)-aminomethane buffer (Sigma-Aldrich Co. LLC).

To determine the refractive indices of the liquid samples, we have chosen a classical yet robust refractometry method based on the measurement of the angle of minimal deviation. The sample suspensions were filled into a hollow prism, which was then inserted into a goniometer. The eyepiece of the goniometer was replaced with a camera sensitive in the near IR. In order to cover the selected wavelength range, two types of light sources were used. In the wavelength range of 390-780 nm, the light of a Xe lamp with a power of $1 \mathrm{~kW}$ was collimated by achromatic lenses. The required wavelength was selected by an SPM-2 monochromator having a bandwidth of $0.4 \mathrm{~nm}$, so that the peak spectral power at the sample never exceeded $60 \mu \mathrm{W}$ within the 390-780 nm range. Hence, the effect of photobleaching could be neglected. For the wavelength range of 780-880 nm, femtosecond laser pulses from 
a $70 \mathrm{MHz}$ Ti:Sa laser oscillator were used. A quasi-monochromatic component of the $100 \mathrm{~nm}$ bandwidth (FWHM) pulses was selected by a Jobin Yvon H20UV monochromator and then was imaged onto the surface of the hollow prism.

These measurements were carried out using the Ti:sapphire oscillator and a high pressure Xe lamp at the TeWaTi Laboratory, Department of Optics and Quantum Electronics, University of Szeged, under the supervision of Dr. Karoly Osvay.

2. The feasibility study of ultrafast optical switching was conducted in the pump-probe scheme utilizing the $10 \mathrm{~Hz}, 800 \mathrm{~nm}$ amplified pulses of a TW-class laser system. The beam was split into two parts. By injecting the more intense beam into an optical parametric amplifier followed by a sum frequency mixer and a compressor, $150 \mathrm{fs}, 80 \mu \mathrm{J}$ green pump pulses were generated. These pulses excited the absorption band of $\mathrm{bR}$ at a center wavelength of $530 \mathrm{~nm}$, starting the photocycle of the membrane protein. The probe pulses were obtained from the less intense beam by utilizing a $18001 / \mathrm{mm}$ line density gold grating, a slit, and a Fabry-Perot interferometer (finesse $\approx 50$ ) to narrow the spectrum yielding $1 \mu \mathrm{J}$ pulse energy and a bandwidth of $0.2 \mathrm{~nm}$ near $790 \mathrm{~nm}$. The transform limited pulse duration was 3 ps. After propagating through a delay line, the probe pulses were directed onto a plane, grating coupled waveguide coated with a bR film. The change in the light intensity coupled into the waveguide under an appropriate angle of incidence was measured with a fast photodiode (Thorlabs, DET10A) and a multichannel oscilloscope (LeCroy WaveRunner 6100A).

These measurements were carried out using the hybrid laser-and optical parametric chirped pulse amplifier system at the TeWaTi Laboratory, Department of Optics and Quantum Electronics, University of Szeged, under the supervision of Dr. Karoly Osvay and Dr. Andras Der.

3. The FAD sample was purchased from Sigma-Aldrich Co. LLC. For my measurements, I prepared a $3 \mathrm{mM}$ stock solution in $50 \mathrm{mM}, \mathrm{pH} 7.0$ phosphate buffer, which was diluted in 1:1 ratio with tri-distilled water, dioxane, ethanol, and DMSO solutions to keep the FAD concentration at a constant value of $1.5 \mathrm{mM}$. The flavocytochrome-bound FAD sample was obtained from Dr. Csaba Bagyinka and Dr. Gabor Rakhely.

For time-resolved fluorescence measurements, we have recently constructed a Ti:sapphire laser oscillator based apparatus capable of measuring time-resolved fluorescence both with the technique of frequency up-conversion and time correlated single photon counting (TCSPC). The output beam of the laser oscillator was split into two beams providing the optical pump and the gate pulses, respectively. The pulses traveling in the pump beamline 
were focused into a beta-barium borate (BBO) crystal in order to generate their second harmonic. The fluorescence emitted as a result of exciting the sample by the so obtained pump beam was collected and focused by a pair of large aperture off-axis parabolic mirrors onto a second BBO crystal constituting the frequency up-conversion unit, where it was sum frequency mixed with the gate pulses. The generated frequency up-converted beam was then focused onto the entrance slit of a monochromator. A liquid nitrogen cooled 1024x256 pixel CCD was mounted on one of the exit ports of the monochromator making it possible to detect all the spectral components simultaneously. A 300 line/mm optical diffraction grating was used to spectrally disperse the beam. In the case of TCSPC, the fluorescence was directly imaged onto the entrance slit of the monochromator instead of traveling through the upconversion unit. The second output port of the monochromator had an avalanche photodiode (IDQuantique, ID-100) mounted onto it, which was connected to a single photon counting electronic unit (Becker \& Hickl GmbH).

These measurements were carried out using a femtosecond Ti:sapphire oscillator at the Laboratory for Femtobiology of the Institute of Biophysics, Biological Research Centre of HAS (Szeged, Hungary) under the supervision of Dr. Geza Groma.

4. In the case of measurements of absorption kinetics, a $3.0 \times 10^{-4} \mathrm{M}$ NADH solution was prepared freshly in 0.1 M PIPES (1,4-Piperazine-diethanesulfonic acid) buffer in $\mathrm{pH}=7.0$ and was kept at $24{ }^{\circ} \mathrm{C}$ during the measurements. This buffer was proven optimal in avoiding thermal NADH degradation. The equilibrium ratio of the folded and unfolded conformational states was controlled by the methanol concentration of the sample. Time-dependent differential absorption spectra upon excitation of the adenine group were measured at 0,50 , 70 and $80 \%$ methanol concentrations.

Femtosecond absorption kinetics measurements were carried out by the standard pump-probe method. The excitation pulses were obtained at $266 \mathrm{~nm}$ by third harmonic generation of an amplified Ti:sapphire laser system $(5 \mathrm{kHz}, 40 \mathrm{fs}, 500 \mu \mathrm{J})$. A white light continuum pulse train was generated by focusing a small portion of the fundamental beam into a piece of bulk material and the 330-630 nm range was selected by spectral filters. The pulses were then split into two beams before reaching the sample: one serving as the probe beam, while the other provided a reference for determining the accurate absorption changes. After the sample, the probe and reference pulses were directed into a monochromator and the spectra were detected by a cooled CCD camera. The time resolution of the kinetic measurements was $\sim 100$ fs. A $0.5 \mathrm{~mm}$ diameter square-aperture quartz cuvette was used as 
sample holder where the liquid samples were circulated using a peristaltic pump. Data analysis and evaluation was performed using Matlab codes including time- and spectral calibration results, background correction data and SVD filtering. The data were then corrected for the solvent response, pump-probe two-photon absorption and solvated electron signals.

These measurements were carried out using an amplified Ti:sapphire laser system at the laboratory of the CNRS-IPCMS DON (Department of Optics and Nanophotonics, Strasbourg, France) under the guidance of Prof. Stefan Haacke.

\section{New scientific results}

My scientific results are summarized in the following thesis statements:

1. From the measurements of the angle of minimum deviation, I have calculated the refractive index values of $\mathrm{bR}$ taking into account the temperature and pressure dependent Sellmeier equation of air. First, I have determined the refractive index of TRIS buffer, then the refractive indices of bR suspensions with different concentration in the wavelength range between 390 and $880 \mathrm{~nm}$. For the first time I have published the Sellmeier coefficients of TRIS buffer and bR suspensions [J1, C1-C4, K1-K3].

2. Employing pump-probe measurements on a thin bR film dried onto the surface of an integrated optical waveguide, I have demonstrated that the peak of resonance of the mode coupled into the waveguide shifts after excitation on a sub-picosecond timescale due to the index change induced by the absorption of bR. Based on the comparison of my measurement results with the time constants of the photocycle of $b R$, I have confirmed that the amplitude of the measured signal is controlled by the index change during the $B R \rightarrow I$ transition. The results suggest that the $B R \rightarrow I$ transition of the photocycle of $b R$ can be exploited for ultrafast switching based purely on optical principles [J2, C5-C9, C11-C16, $\mathrm{C} 20, \mathrm{~K} 4, \mathrm{~K} 5]$.

3. I have participated in the construction and calibration of a complex apparatus for the measurement of femtosecond time-resolved fluorescence kinetics. I have measured the fluorescence kinetics of FAD in a wide time- and spectral range in water, water-dioxane, water-ethanol, water-DMSO solutions. The fluorescence kinetics was also investigated when the FAD molecule was bound to flavocytochrome, which helps to understand the intra- and extramolecular interactions of the coenzyme. Employing a new evaluation 
algorithm for the first time (Basis Pursuit Denoising), I have determined that the fluorescence of FAD is characterized by four decay components, which can be attributed to one open and three closed conformations. In addition, a 500-fs time constant was also identified and linked to salvation dynamics in water. FCC fluorescence kinetics, which was studied for the first time in this work, showed quenching larger than in all other environments, which suggests a strong interaction between the chromophore and the amino acid side chains. The experiments conducted in a wide temporal and spectral range and the data analyzed using new and very efficient methods resulted in a model of the fluorescence mechanisms of FAD, which is more thorough and complex than the earlier models in the literature [J3, J4, C10, C17, C19, C21, K6].

4. I have measured the transient absorption of NADH using a femtosecond pump-probe technique at $0 \%, 50 \%, 70 \%$, and $80 \%$ methanol concentrations, which provide information about the different conformational states of the molecule. The global analysis of the measured data yielded the time constants of $250 \mathrm{fs}, 3 \mathrm{ps}$, and $350 \mathrm{ps}$. The $250-\mathrm{fs}$ time constant can be attributed to the excited state absorption of the adenine group. The other two decay components have large amplitude values in methanol-free samples. These observations suggest that the energy transfer in water from adenine to nicotinamide is characterized by a 3-ps time constant, while the nicotinamide group returns to the ground state in $250 \mathrm{ps}$. The population of the closed conformational state, which facilitates energy transfer, gradually decreases with increasing methanol concentration [J5, C18], which leads to a decrease of the weight of the above slow components. 


\subsection{A TÉZISEK ALAPJÁT KÉPEZÖ SAJÁT KÖZLEMÉNYEK JEGYZÉKE}

\section{REFERÁLT FOLYÓIRATOKBAN, KÖNYVFEJEZETEKBEN}

J1. Z. Heiner, K. Osvay Refractive Index of Dark-Adapted Bacteriorhodopsin and TRIS Buffer between 390-880 nm Applied Optics 48, 4610-4615, 2009

J2. L. Fábián, Z. Heiner, M. Mero, M Kiss, E. Wolff, P. Ormos, K. Osvay, A. Dér Protein-based ultrafast photonic switching Optics Express 19, 18861-18870 (2011)

J3. G. I. Groma, Z. Heiner, A. Makai, F. Sarlos Estimation of kinetic parameters from time-resolved fluorescence data: A compressed sensing approach RSC Advances 2, 11481-11490 (2012)

J4. Z. Heiner, A. Makai, F. Sarlós, C. Bagyinka, A. Tóth, G. Rákhely, G. I. Groma Fluorescence Kinetics of Flavin Adenine Dinucleotide in Different Microenvironments EPJ Web of Conferences 41, 07021 (2013)

J5. Z. Heiner, T. Roland, S. Haacke, G. I. Groma Ultrafast Absorption Kinetics of NADH in Folded and Unfolded Conformations EPJ Web of Conferences 41, 07003 (2013)

\section{REFERÁlt ÉS PUblikÁLt KONFERENCIA-KIADVÁNYOKBAN}

C1. Z. Heiner, G. Szalay, K. Osvay: Ultrafast dispersion measurement of $b R$ in the near IR range EOS Annual Meeting 2006, Paris, France, P13, 2006

C2. G. Szalay, Z. Heiner, K. Osvay: Dispersion of dark BacterioRhodopsin at $800 \mathrm{~nm}$ ECAMP IX. 2007, Crete, Greece, paper Tu3-1, 2007

C3. Z. Heiner, G. Szalay, K. Osvay Refractive Index and Dispersion Measurement of Dark-Adapted Wild Type Bacteriorhodopsin Trends of Laser Applications in Biology and Biomedicine, Heraklion, Greece 2008 (szóbeli előadás)

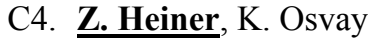
Measurement of the Concentration Dependent Refractive Index of Dark-Adapted Wild-type Bacteriorhodopsin in 390-880 nm CLEO®/Europe-EQEC 2009, Munich, Germany, paper: CL1.2 THU (szóbeli előadás)

C5. L. Fábián, M. Mero, Z. Heiner, K. Osvay, A. Dér Ultrafast Integrated Optical Switching Based on the Protein Bacteriorhodopsin SPIE Photonics Europe 2010, Brussels, Belgium (szóbeli előadás)

C6. L. Fábián, M. Mero, Z. Heiner, M. Kiss, K. Osvay, A. Dér Ultrafast Integrated Optical Switching Based on the Protein Bacteriorhodopsin CLEO 2010, San Jose, USA (szóbeli előadás)

C7. Z. Heiner, L. Fábián, M. Mero, M. Kiss, K. Osvay, A. Dér Ultrafast, Protein-Based All-Optical Switching Ultrafast Phenomena 2010, Snowmass, Colorado United States, ThE18

C8. A. Dér, L. Fábián, Z. Heiner, M. Kiss, M. Mero, K. Osvay Ultrafast all-optical switching and dispersion of the protein Bacteriorhodopsin ICOOPMA10 2010, Budapest, Hungary (meghívott szóbeli előadás)

C9. Z. Heiner, L. Fábián, M. Mero, M. Kiss, A. Dér, K. Osvay Bacteriorhodopsin based ultrafast all-optical switching 10th European Conference on Atoms Molecules and Photons 2010, Salamanca, Spain, paper 758

C10.Z. Heiner, A. Makai, G. I. Groma Ultrafast fluorescence kinetics measurement based on up-conversion method COST Meeting \& Training School, Nonlinear Nanophotonics 2010, Visegrád, Hungary

C11.Pal Ormos, L. Fabian, Z. Heiner, M. Mero, M. Kiss, E. Wolff, K. Osvay, A. Der Subpicosecond photonic switching based on bacteriorhodopsin $55^{\text {th }}$ Annual Meeting of Biophysical Society 2011, Baltimore, USA, 2634-Pos/B620

C12.Pal Ormos, L. Fabian, Z. Heiner, M. Mero, M. Kiss, E. Wolff, K. Osvay, A. Der Subpicosecond photonic switching based on bacteriorhodopsin APS March Meeting 2011, Volume 56, Number 2 (S1.00068) 
C13.L. Fábián, Z. Heiner, M. Mero, M. Kiss, E.K. Wolff, P. Ormos, K. Osvay, A. Der Ultrafast photonic switching based on the protein bacteriorhodopsin SPIE Optics and Optoelectronics 2011 Prague, Czech Republic [8071-39]

C14.L. Fábián, Z. Heiner, M. Mero, M. Kiss, E.K. Wolff, P. Ormos, K. Osvay, A. Der Subpicosecond all-optical switching by the protein bacteriorhodopsin VIII. European Biophysics Congress 2011 Budapest, Hungary [P-760]

C15.L. Fábián, Z. Heiner, M. Mero, M Kiss, E. Wolff, P. Ormos, K. Osvay, A. Dér Subpicosecond all-optical switching by the protein bacteriorhodopsin European Biophysics Journal 40 S236 (2011)

C16.L. Fábián, Z. Heiner, M. Mero, M. Kiss, E.K. Wolff, P. Ormos, K. Osvay, A. Der Protein-based ultrafast all-optical switching 13th International Conference-School (2011) "Advanced Materials and Technologies" Palanga, Lithuania [P39]

C17.Z. Heiner, A. Makai, F. Sarlós, Cs. Bagyinka, A. Tóth, G. Rákhely,G. I. Groma Fluorescence Kinetics of Flavin Adenine Dinucleotide in Different Microenvironments $18^{\text {th }}$ International Conf. on Ultrafast Phenomena Lausanne, Svájc (2012) [MON.PI.76]

C18. Z. Heiner, T. Roland, S. Haacke, G. I. Groma Ultrafast Absorption Kinetics of NADH in Folded and Unfolded Conformations $18^{\text {th }}$ International Conf. on Ultrafast Phenomena Lausanne, Svájc (2012) [MON.PI.76]

C19.Z. Heiner, A. Makai, F. Sarlós, Cs. Bagyinka, A. Tóth, G. Rákhely,G. I. Groma Ultrafast time-resolved fluorescence of Flavine Adenine Dinucleotide Regional Biophysics Conference 2012, Kladovo-Belgrád, Szerbia [P2.S1]

C20.L. Fábián, Z. Heiner, M. Mero, M. Kiss, E. K. Wolff, P. Ormos, K. Osvay, A. Dér Protein-based ultrafast all-optical switching The 11th Greta Pifat Mrzljak International School of Biophysics, Primosten, Croatia (2012) Book of Abstracts P25

C21.Z. Heiner, A. Makai, F. Sarlós, G. I. Groma A compressed sensing approach for kinetic parameter estimation from time-resolved fluorescence data Chemometrics in Time-Resolved and Imaging Spectroscopy, Lille, France (2012)

\section{EGYÉB KONFERENCIÁKON}

K1. Z. Heiner, G.Szalay, K.Osvay The dispersion of dark-adapted bacteriorhodopsin at $800 \mathrm{~nm}$ STRAUB-NAPOK, Szeged, Biophysics Section, 2007

K2. Z. Heiner, K.Osvay A bakteriorodopszin törésmutatójának mérése a 390-880 nm közötti tartományon Kvantumelektronika 2008, Budapest

K3. Z. Heiner, K.Osvay A bakteriorodopszin koncentrációfüggõ diszperziójának mérése a közeli infravörös tartományon MBFT XXIII. Kongresszusa, Pécs, P42 (2009)

K4. Z. Heiner, L. Fábián, M. Merö, M. Kiss, A. Dér, K. Osvay Ultragyors optikai fénykapcsolás fehérjével Fizikus Vándorgyülés, 2010, Pécs (szóbeli előadás)

K5. László Fábián, Zsuzsanna Heiner, Mark Mero, Miklós Kiss, Elmar K. Wolff, Pál Ormos, Károly Osvay and András Dér: Protein-based ultrafast photonic switching Straub Days, 2010, Szeged, Hungary (szóbeli előadás)

K6. Z. Heiner, A. Makai, F. Sarlós, G.I. Groma Ultrafast fluorescence kinetics measurements based on up-conversion method Straub Days, 2010, Szeged, Hungary 


\section{RöVIDÍTÉSEK JEGYZÉKE}

\begin{tabular}{|c|c|c|}
\hline RöVITÍTÉS & ANGOL NYELVÜ KIFEJEZÉS & MAGYAR NYELVÜ KIFEJEZÉS \\
\hline ADP & adenosin diphosphate & adenozin difoszfát \\
\hline ATP & adenosin triphosphate & adenozin trifoszfát \\
\hline BBO & $\beta$-Barium-Borate $\left(\beta-\mathrm{BaB}_{2} \mathrm{O}_{4}\right)$ & $\beta$-Bárium-Borát $\left(\beta-\mathrm{BaB}_{2} \mathrm{O}_{4}\right)$ \\
\hline BPDN & basis persuit denoising & Basis Persuit Denoising \\
\hline $\mathrm{bR}$ & bacteriorhodopsin & bakteriorodopszin \\
\hline $\mathrm{CCF}$ & cross-correlation function & keresztkorrelációs függvény \\
\hline $\mathrm{CCW}$ & counter clockwise & óramutató járásával ellentétes \\
\hline CEP & carrier-envelope phase & hordozó-burkoló fázis \\
\hline CPA & chirped pulse amplification & fázismodulált impulzuserősítés \\
\hline $\mathrm{CW}$ & clockwise & óramutató járásával megegyező \\
\hline DAS & decay-associated spectrum & amplitudó spektrum \\
\hline ESA & excited state absorption & gerjesztett állapoti abszorpció \\
\hline FAD & flavin adenine dinucleotide & flavin adenin dinukleotid \\
\hline FCC & flavocytocrome C & flavocitokróm C \\
\hline FLIM & fluorescence lifetime imaging & fluoreszcencia életidő képalkotás \\
\hline \multirow[t]{2}{*}{ FRET } & Förster resonance energy transfer $\underline{o r}$ & Förster-rezonancia energiaátadás $\underline{v a g y}$ \\
\hline & Fluorescence resonance energy transfer & fluoreszcencia rezonancia energiaátadás \\
\hline GD & group delay & csoportkésleltetés \\
\hline GDD & group delay dispersion & csoportkésleltetés-diszperzió \\
\hline IC & internal conversion & belső átalakulás \\
\hline IRF & instrument response function & készülék átviteli függvény \\
\hline ISC & intersystem crossing & rendszerek közti átmenet \\
\hline NAD & nicotinamide adenine dinucleotide & nikotinamid adenin dinukleotid \\
\hline NADH & reduced nicotinamide adenine dinucleotide & redukált nikotinamid adenin dinukleotid \\
\hline
\end{tabular}




\begin{tabular}{lll}
\hline NLO & nonlinear optical & nem-lineáris optikai \\
OD & optical density & optikai denzitás \\
OPCPA & optical parametric chirped-pulse & optikai parametrikus fázismodulált \\
& amplification & impulzuserösítés \\
OWLS & optical waveguide lightmode spectroscopy & optikai hullámvezető módusspektroszkópia \\
RPET & relative probability for energy transfer & energiatranszfer képessége \\
SE & stimulated emission & stimulált emisszió \\
SFG & sum-frequency generation & összegfrekvencia keltése \\
SHG & second harmonic generation & másodharmonikus keltése \\
SPR & surface plasmon resonance & felületi plazmon rezonancia \\
SVD & singular value decomposition & szinguláris értékek szerinti felbontás \\
TAC & time-amplitude converter & idő-amplitudó átalakító \\
TCSPC & time-correlated single photon counting & időkorrelált egy-foton számláló \\
TE & transverse electric & transzverzális elektromos \\
TM & transverse magnetic & transzverzális mágneses \\
TOD & third order dispersion & harmadrendü diszperzió \\
TPA & two photon absorption & fehér fény kontinuum \\
WLC & white light continuum & \\
\hline & &
\end{tabular}




\section{KöSZÖNETNYILVÁNÍTÁS}

Ezúton fejezem ki köszönetemet témavezetőimnek, Dr. Osvay Károlynak és Dr. Groma Gézának, hogy bizalmukkal, irányításukkal és útmutatásukkal mindezidáig a helyes út irányába tereltek, és irányt adtak kutatásaimnak. Köszönöm, hogy részt vehettem a Szegedi Biológia Központban egy új femtoszekundumos labor felépítésében, amelynek során nagyon sok ismeretet sajátítottam el mind a szinkronpumpált optikai parametrikus oszcillátorokról, mind pedig az időbontott fluoreszcencia spektroszkópiai módszerekről. Köszönet témavezetőim türelméért - $\mathrm{s}$ egyben bocsánat az esetlegesen okozott ősz hajszálakért. Hálásan köszönöm Dr. Stefan Haacke-nak, hogy lehetőséget adott a csoportjában dolgozni, és nagyon sok új elméleti és kísérleti ismereteket szerezhettem az időbontott spektroszkópia területén.

Köszönetet szeretnék mondani Dr. Bor Zsolt, Dr. Szabó Gábor és Dr. Rácz Béla professzor úrnak, hogy lehetővé tették számomra, hogy az SZTE Optikai és Kvantumelektronikai Tanszéken kutatómunkát folytathassak, illetve bekapcsolódhassak az SZTE Fizikai Doktori Iskola ösztöndíjasainak körébe.

Köszönöm a TeWaTi csoport 2002-2008 tagjainak tanácsait, észrevételeit. Kiemelten köszönöm Börzsönyi Ádámnak, hogy a számítógépek ellen küldött negatív impulzusaim korrigálta közös munkáink során.

Hálás köszönetem fejezem ki Makai András, Fábián László és Dr. Dér András SZBKs kollégáim felé, akiktől sokat tanulhattam. Köszönöm Dr. Ormos Pál akadémikusnak, hogy lehetőséget adott a Szegedi Biológiai Központ Biofizikai Intézetében zajló kutatásokba bekapcsolódni, mint MTA Fiatal Kutató.

Köszönöm egykori témavezetőmnek, Dr. Vinkó Józsefnek is, hogy hallgató koromban megtanított tanulni, s egyben köszönöm az „első szegedi csillagász diplomát kapott” évfolyamtársaimnak is a küzdésszellem és a szakmai rajongásaim kialakításában való közreműködését.

Hálás köszönet illeti Kedvesem, Gyermekeim, Szüleim, Nagyszüleim, Nagybátyáim és Barátaim is, akik elviseltek, segítettek, formáltak. És kitartanak velem jóban-rosszban... hagyva, hogy a magam útját járjam...

Köszönöm!

Szeged, 2013. május

Heiner Zsuzsanna

MTA SzBK, Biofizikai Intézet 
A dolgozatban közölt eredmények elérését az OTKA K75149, az NKFP 1/00007/2005, a TÁMOP-4.2.1, a TÁMOP-4.2.2, a TECH-09 valamint az Európai Regionális Projektek támogatták. A strasbourgi csoporton keresztül pedig köszönet O. Crégut technikai segítségéért. 


\section{IRODALOMJEGYZÉK}

1. L. E. Hargrove, R. L. Fork, and M. A. Pollock, "Locking of He-Ne laser modes induced by synchronous intracavity modulation" Applied Physics Letters 5, 4-5 (1964)

2. O. E. Martinez, J. P. Gordon, and R. L. Fork, "Negative group-velocity dispersion using refraction" JOSA A 1, 1003-1006 (1984)

3. R. L. Fork, O. E. Martinez, and J. P. Gordon, "Negative dispersion using pairs of prisms" Optics Letters 9, 150-152 (1984)

4. Zs. Bor, and B. Rácz, "Group velocity dispersion in prisms and its application to pulse compression and travelling-wave excitation" Optics Communications 54, 165-170 (1985)

5. J. A. Valdmanis, R. L. Fork, and J. P. Gordon, "Generation of optical pulses as short as 27 femtoseconds directly from a laser balancing self-phase modulation, group-velocity dispersion, saturable absorption, and saturable gain" Optics Letters 10, 131-133 (1985)

6. F. X. Kärtner, N. Matuschek, T. Schibli, U. Keller, H. A. Haus, C. Heine, R. Morf, V. Scheuer, M. Tilsch, and T. Tschudi, "Design and fabrication of double-chirped mirrors" Optics Letters 22, 831-833 (1997)

7. G. Tempea, V. Yakovlev, B. Bacovic, F. Krausz, and K. Ferencz, "Tilted-front-interface chirped mirrors" JOSA B 18, 1747-1750 (2001)

8. R. Szipöcs, F. Kárpát, C. Spielmann, and F. Krausz, "Chirped multilayer coatings for broadband dispersion control in femtosecond lasers" Optics Letters 19, 201-203 (1994)

9. D. H. Sutter, G. Steinmeyer, L. Gallmann, N. Matuschek, F. Morier-Genoud, U. Keller, V. Scheuer, G. Angelow, and T. Tschudi, "Semiconductor saturable-absorber mirror assisted Kerr-lens mode-locked Ti:sapphire laser producing pulses in the two-cycle regime" Optics Letters 24, 631-633 (1999)

10. A. Apolonski, A. Poppe, G. Tempea, Ch. Spielmann, Th. Udem, R. Holzwarth, T. W. Hänsch, and F. Krausz, "Controlling the Phase Evolution of Few-Cycle Light Pulses" Phys. Rev. Lett. 85, 740-743 (2000)

11. V.S. Yakovlev, P. Dombi, G. Tempea, C. Lemell, J. Burgdörfer, T. Udem, and A. Apolonski, "Phase-stabilized 4-fs pulses at the full oscillator repetition rate for a photoemission experiment" Applied Physics B 76, 329-332 (2003) 
12. A. Baltuska, Th. Udem, M. Uiberacker, M. Hentschel, E. Goulielmakis, Ch. Gohle, R. Holzwarth, V. S. Yakovlev, A. Scrinzi, T. W. Hänsch, and F. Krausz, "Attosecond control of electronic processes by intense light fields" Nature 421, 611-615 (2003)

13. C. V. Shank, R. L. Fork, R. F. Leheny, and J. Shah, "Dynamics of Photoexcited GaAs Band-Edge Absorption with Subpicosecond Resolution" Phys. Rev. Lett. 42, 112-115 (1979)

14. D. Strickland, and G. Mourou, "Compression of amplified chirped optical pulses" Optics Communications 56, 219-221 (1985)

15. P. Maine, D. Strickland, P. Bado, M. Pessot, and G. Mourou, "Generation of ultrahigh peak power pulses by chirped pulse amplification" IEEE Journal of Quantum Electronics 24, 398-403 (1988)

16. C. Rouyer, É. Mazataud, I. Allais, A. Pierre, S. Seznec, C. Sauteret, G. Mourou, and A. Migus, "Generation of 50-TW femtosecond pulses in a Ti:sapphire/Nd:glass chain" Opt. Lett. 18, 214-216 (1993)

17. M. Dantus, R. M. Bowman, and A. H. Zewail, "Femtosecond laser observations of molecular vibration and rotation" Nature 343, 737-739 (1990)

18. A. H. Zewail, "Laser femtochemistry" Science 242, 1645-1653 (1988)

19. A. H. Zewail, "Femtochemistry: Atomic-Scale Dynamics of the Chemical Bond Using Ultrafast Lasers (Nobel Lecture)," in Femtochemistry(Wiley-VCH Verlag GmbH, 2001), pp. 1-85.

20. W. Stoeckenius, and R. Rowen, "A morphological study of Halobacterium Halobium and its lysis in media of low salt concentration" The Journal of Cell Biology 34, 365$393(1967)$

21. R. H. Lozier, R. A. Bogomolni, and W. Stoeckenius, "Bacteriorhodopsin: a LightDriven Proton Pump in Halobacterium Halobium" Biophysical Journal 15, 955-962 (1975)

22. D. Oesterhelt, and W. Stoeckenius, "Functions of a new photoreceptor membrane" Proceedings of the National Academy of Sciences 70, 2853-2857 (1973)

23. O. Beja, L. Aravind, E. V. Koonin, M. T. Suzuki, A. Hadd, L. P. Nguyen, S. B. Jovanovich, C. M. Gates, R. A. Feldman, J. L. Spudich, E. N. Spudich, and E. F. DeLong, "Bacterial Rhodopsin: Evidence for a New Type of Phototrophy in the Sea" Science 289, 1902-1906 (2000) 
24. H. G. Khorana, G. E. Gerber, W. C. Herlihy, C. P. Gray, R. J. Anderegg, K. Nihei, and K. Biemann, "Amino acid sequence of bacteriorhodopsin" Proceedings of the National Academy of Sciences 76, 5046-5050 (1979)

25. L.-O. Essen, "Halorhodopsin: light-driven ion pumping made simple?" Current Opinion in Structural Biology 12, 516-522 (2002)

26. H. Luecke, "Atomic resolution structures of bacteriorhodopsin photocycle intermediates: the role of discrete water molecules in the function of this light-driven ion pump" BBA 1460, 133-156 (2000)

27. J. A. Stuart, D. L. Marcy, and R. R. Birge, "Photonic and optoelectronic application of bacteriorhodopsin," in Bioelectronic Applications of Photochromic Pigments, A. Dér, and L. Keszthelyi, eds. (2001), pp. 15-29.

28. S. P. Balashov, "Photoreactions of the photointermediates of bacteriorhodopsin" Israel Journal of Chem 35, 415-428 (1995)

29. P. Ormos, Z. Dancsházy, and L. Keszthelyi, "Electric response of a back photoreaction in the bacteriorhodopsin photocycle" Biophysical Journal 31, 207-213 (1980)

30. A. Colonna, G. I. Groma, and M. H. Vos, "Retinal isomerization dynamics in dry bacteriorhodopsin films" Chem. Phys. Letters 415, 69-73 (2005)

31. G. Váró, and L. Keszthelyi, "Photoelectric signals from dried oriented purple membranes of Halobacterium halobium" Biophysical Journal 43, 47-51 (1983)

32. A. C. Terentis, L. Ujj, H. Abramczyk, and G. H. Atkinson, "Primary events in the bacteriorhodopsin photocycle: Torsional vibrational dephasing in the first excited electronic state" Chemical Physics 313, 51-62 (2005)

33. D. Zeisel, and N. Hampp, "Spectral relationship of light-induced refractive index and absorption changes in bacteriorhodopsin films containing wildtype BR and the variant BR-D96N" J. Phys. Chem. 96, 7788-7792 (1992)

34. L. Fábián, E. K. Wolff, L. Oroszi, P. Ormos, and A. Dér, "Fast integrated optical switching by the protein bacterorhodopsin" Appl. Phys. Lett. 97, 023305 (2010)

35. L. Zimányi, "Analysis of the Bacteriorhodopsin Photocycle by Singular Value Decomposition with Self-Modeling: A Critical Evaluation Using Realistic Simulated Data " J. Phys. Chem. B 108, 4199-4209 (2004)

36. J. M. Hales, J. Matichak, S. Barlow, S. Ohira, K. Yesudas, J.-L. Bredas, J. W. Perry, and R. R. Marder, "Design of polymethine dyes with large third-order optical nonlinearities and loss figures of merit" Science 327, 1485-1487 (2010) 
37. S. A. Haque, and J. Nelson, "Toward organic all-optical switching" Science 327, 14661467 (2010)

38. X. Hu, P. Jiang, C. Ding, H. Yang, and Q. Gong, "Picosecond and low-power alloptical switching based on an organic photonic bandgap microcavity" Nature Photonics 2, 185-189 (2008)

39. A.Dér, L.Fábián, S.Valkai, and P.Ormos, "Az integrált optika biofizikai alkalmazásai " in A kvantumoptika és -elektronika legújabb eredményei, Z. Heiner, and K. Osvay, eds. (SzTE, 2006).

40. P. Ormos, L. Fabian, L. Oroszi, E. K. Wolff, J. J. Ramsden, and A. Der, "Protein-based integrated optical switching and modulation " Appl. Phys. Lett. 80, 4060-4062 (2002)

41. A. Dér, P. Hargittai, and J. Simon, "Time-resolved photoelectric and absorption signals from oriented purple membranes immobilized in gel" J. Biochem. Biophys. Meth. 10, 295-300 (1985)

42. D. Oesterhelt, C. Bräuchle, and N. Hampp, "Bacteriorhodopsin: a biological material for information processing" Quarterly Reviews of Biophysics 24, 425-478 (1991)

43. J. A. Stuart, D. L. Marcy, K. J. Wise, and R. R. Birge, "Volumetric optical memory based on bacteriorhodopsin" Synthetic Metals 127, 3-15 (2002)

44. Q. W. Song, C. P. Zhang, and R.R.Birge, "Optical limiting by chemically enhanced bacteriorhodopsin films " Opt. Lett. 18, 775-777 (1993)

45. O. Werner, B. Fischer, A. Lewis, and I. Nebenzahl, "Saturable absorption, wave mixing, and phase conjugation with bacteriorhodopsin" Opt. Lett. 15, 1117-1119 (1990)

46. K. Clays, S. Van Elshocht, M. Chi, E. Lepoudre, and A. Persoons, "Bacteriorhodopsin: a natural, efficient (nonlinear) photonic crystal" J. Opt. Soc. Am. B 18, 1474-1482 (2001)

47. O. Bouevitch, A. Lewis, and M. Sheves, "Probing Bacteriorhodopsin Photochemistry with Nonlinear Optics: Comparing the Second Harmonic Generation of $b R$ and the Photochemically Induced Intermediate $K^{\prime \prime}$ The Journal of Physical Chemistry 99, 10648-10657 (1995)

48. J. Y. Huang, Z. Chen, and A. Lewis, "Second-harmonic generation in purple membrane-poly(vinyl alcohol) films: probing the dipolar characteristics of the bacteriorhodopsin chromophore in bR570 and M412" The Journal of Physical Chemistry 93, 3314-3320 (1989) 
49. R. R. Schaller, "Moore's law: past, present and future" IEEE Spectrum 34, 52-59 (1997)

50. W. W. Gibbs, "Computing at the speed of light" Sci.Am. 291, 80-87 (2004)

51. Ádám, Dux, Faragó, Fésüs, Machovich, Mandl, and Sümegi, "Orvosi Biokémia," Á. Veronika, ed. (Medicina, Budapest, 2006).

52. Hrabák, Idei, Mészáros, Staub, Tóth, and Vér, Biokémia - Aminosavak, peptidek, szénhidrátok, lipidek, nukleotidok, nukleinsavak, vitaminok és koenzimek szerkezete és tulajdonságai (jegyzet) (Semmelweis Kiadó, 2006).

53. M. Brownlee, "Biochemistry and molecular cell biology of diabetic complications" Nature 414, 813 (2001)

54. "http://www.mikeblaber.org/oldwine/BCH4053/Lecture33/Lecture33.html."

55. H. Chosrowjan, S. Taniguchi, N. Mataga, F. Tanaka, and A. J. W. G. Visser, "The stacked flavin adenine dinucleotide conformation in water is fluorescent on picosecond timescale" Chemical Physics Letters 378, 354-358 (2003)

56. T. Nakabayashi, M. S. Islam, and N. Ohta, "Fluorescence Decay Dynamics of Flavin Adenine Dinucleotide in a Mixture of Alcohol and Water in the Femtosecond and Nanosecond Time Range" The Journal of Physical Chemistry B 114, 15254-15260 (2010)

57. N. Nakashima, K. Yoshihara, F. Tanaka, and K. Yagi, "Picosecond fluorescence lifetime of the coenzyme of D-amino acid oxidase" Journal of Biological Chemistry 255 , 5261-5263 (1980)

58. Md. S. Islam, M. Honma, T. Nakabayashi, M. Kinjo, and N. Ohta, "pH Dependence of the Fluorescence Lifetime of FAD in Solution and in Cells" Int. J. Mol. Sci. 14, 19521963 (2013)

59. R. V. Hull, P. S. Conger Iii, and R. J. Hoobler, "Conformation of NADH studied by fluorescence excitation transfer spectroscopy" Biophysical Chemistry 90, 9-16 (2001)

60. L. Rover Jr, J. C. B. Fernandes, Graciliano de Oliveira Neto, L. T. Kubota, E. Katekawa, and S. H. P. Serrano, "Study of NADH Stability Using Ultraviolet-Visible Spectrophotometric Analysis and Factorial Design" Analytical Biochemistry 260, 50-55 (1998)

61. A. S. Ladokhin, and L. Brand, "Evidence for an excited-state reaction contributing to NADH fluorescence" Journal of Fluorescence 5, 99-106 (1995) 
62. K. Blinova, S. Carroll, S. Bose, A. V. Smirnov, J. J. Harvey, J. R. Knutson, and R. S. Balaban, "Distribution of Mitochondrial NADH Fluorescence Lifetimes: Steady-State Kinetics of Matrix NADH Interactions" Biochemistry 44, 2585-2594 (2005)

63. D. Chorvat, and A. Chorvatova, "Multi-wavelength fluorescence lifetime spectroscopy: a new approach to the study of endogenous fluorescence in living cells and tissues" Laser Physics Letters 6, 175-193 (2009)

64. R. Richards-Kortum, and E. Sevick-Muraca, "Quantitative Optical Spectroscopy for Tissue Diagnosis" Annual Review of Physical Chemistry 47, 555-606 (1996)

65. T. Nakabayashi, M.S. Islam, and N. Ohta, "Fluorescence decay dynamics of flavin adenine dinucleotide in a mixture of alcohol and water in the femtosecond and nanosecond time range" J. Phys. Chem. B 114, 15254-15260 (2010)

66. M. C. Skala, K. M. Riching, A. Gendron-Fitzpatrick, J. Eickhoff, K. W. Eliceiri, J. G. White, and N. Ramanujam, "In vivo multiphoton microscopy of NADH and FAD redox states, fluorescence lifetimes, and cellular morphology in precancerous epithelia" Proceedings of the National Academy of Sciences 104, 19494-19499 (2007)

67. D. Schweitzer, F. G. Holz, and R. Spaide, "Metabolic Mapping: Medical Retina," G. K. Krieglstein, and R. N. Weinreb, eds. (Springer Berlin Heidelberg, 2010), pp. 107-123.

68. N. D. Evans, L. Gnudi, O. J. Rolinski, D. J. S. Birch, and J. C. Pickup, "Glucosedependent changes in $N A D(P) H$-related fluorescence lifetime of adipocytes and fibroblasts in vitro: Potential for non-invasive glucose sensing in diabetes mellitus" Journal of Photochemistry and Photobiology B: Biology 80, 122-129 (2005)

69. J. McGinty, N. P. Galletly, C. Dunsby, I. Munro, D. S. Elson, J. Requejo-Isidro, P. Cohen, R. Ahmad, A. Forsyth, A. V. Thillainayagam, M. A. A. Neil, P. M. W. French, and G. W. Stamp, "Wide-field fluorescence lifetime imaging of cancer" Biomed. Opt. Express 1, 627-640 (2010)

70. R. Drezek, K. Sokolov, U. Utzinger, I. Boiko, A. Malpica, M. Follen, and R. RichardsKortum, "Understanding the contributions of NADH and collagen to cervical tissue fluorescence spectra: Modeling, measurements, and implications" Journal of Biomedical Optics 6, 385-396 (2001)

71. B. E. A. Saleh, and M. C. Teich, "Electromagnetic Optics," in Fundamentals of Photonics(John Wiley \& Sons, Inc., 1991), pp. 157-192.

72. R. W. Boyd, Nonlinear Optics (Academic Press, 2008).

73. H. M. Nussenzveig, Causality and Dispersion Relations (Academic Press, New York, 1972). 
74. F. Wooten, Optical Properties of Solids (Academic Press, New York, 1972).

75. P. W. Langhoff, and M. Karplus, "Padé Summation of the Cauchy Dispersion Equation" J. Opt. Soc. Am. 59, 863-871 (1969)

76. S. Ciulli, and G. Nenciu, "Weighted dispersion relations" and cut to cut extrapolations" Communications in Mathematical Physics 26, 237-246 (1972)

77. Sellmeier, "Zur Erklärung der abnormen Farbenfolge im Spectrum einiger Substanzen" Annalen der Physik 219, 272-282 (1871)

78. Z. Heiner, and K. Osvay, eds. A kvantumoptika és -elektronika legújabb eredményei (Szegedi Tudományegyetem, Szeged, 2006).

79. A.Baltuska, M.Uiberacker, E.Goulielmakis, R.Kienberger, V.Yakovlev, Th.Udem, T.Hänsch, and F.Krausz, "Phase controlled amplification of few-cycle laser pulses" IEEE J. Sel. Topics Quantum Electron. 9, 972-989 (2003)

80. D. J. Jones, S. A. Diddams, J. K. Ranka, A. Stentz, R. S. Windeler, J. L. Hall, and S. T. Cundiff, "Carrier-Envelope Phase Control of Femtosecond Mode-Locked Lasers and Direct Optical Frequency Synthesis" Science 288, 635-639 (2000)

81. R. K. Shelton, L.-S. Ma, H. C. Kapteyn, M. M. Murnane, J. L. Hall, and J. Ye, "PhaseCoherent Optical Pulse Synthesis from Separate Femtosecond Lasers" Science 293, 1286-1289 (2001)

82. Hámori András, and N. Nagy, "Integrált optikai szenzorok," (ftp://alag3.mfa.kfki.hu/PUB/Optics/Optikai\%20szenzorok.pdf., Budapest).

83. P.K. Tien, "Integrated optics and new wave phenomena in optical waveguides" Reviews of Modern Physics 49, 361-420 (1977)

84. B. Liedberg, C. Nylander, and I. Lunström, "Surface plasmon resonance for gas detection and biosensing" Sensors and Actuators 4, 299-304 (1983)

85. N. L. Thompson, T. P. Burghardt, and D. Axelrod, "Measuring surface dynamics of biomolecules by total internal reflection fluorescence with photobleaching recovery or correlation spectroscopy" Biophysical Journal 33, 435-454 (1981)

86. N. J. Harrick, Internal reflection spectroscopy (Harrick Scientific Corp., Ossining, N.Y., 1967).

87. R. W. Watkins, and C. R. Robertson, "A total internal-reflection technique for the examination of protein adsorption" Journal of Biomedical Materials Research 11, 915938 (1977)

88. M. Born, and E. Wolf, Principles of Optics (Pergamon, London, 1959).

89. M. V. Klein, and T. E. Furtak, Optik (Springer-Verlag, Berlin, 1984). 
90. J. J. Ramsden, "Review of new experimental techniques for investigating random sequential adsorption" Journal of Statistical Physics 73, 853-877 (1993)

91. K. Tiefenthaler, and W. Lukosz, "Optical sensor for selective detection of substances and/or for the detection of refractive index changes in gaseous, liquid, solid and porous samples," in United States Patent(Oerlikon-Buhrle Holding AG, Zurich, Switzerland, 1989).

92. H. P. Braun, "Wave-guide spectroscopy of biological material" Berichte der Bunsengesellschaft für physikalische Chemie 93, 358-364 (1989)

93. K. Tiefenthaler, and W. Lukosz, "Sensitivity of grating couplers as integrated-optical chemical sensors" J. Opt. Soc. Am. B 6, 209-220 (1989)

94. S. Damjanovich, J. Fidy, and J. Szöllösi, Orvosi Biofizika (Medicina, Budapest, 2006).

95. Ian

D. Johnson, and

M. W.

Davidson, "http://www.olympusmicro.com/primer/java/jablonski/jabintro/index.html."

96. J. R. Lakowicz, Principles of Fluorescence Spectroscopy Third Edition (Springer, Baltimore, 2006).

97. W. Becker, Advanced Time-Correlated Single Photon Counting Techniques (Springer, Heidelberg, 2005).

98. David Birch, and R. Imhof, "Time-Domain Fluorescence Spectroscopy Using TimeCorrelated Single-Photon Counting," in Topics in Fluorescence Spectroscopy, J. R. Lakowicz, ed. (Kluwer Academic Publishers, Boston, 2002), pp. 1-95.

99. N. H. Schiller, "Picosecond streak camera photonics," in Semiconductors probed by ultrafast laser spectroscopy(Academic Press, New York, 1984), pp. 441-458.

100. W. Becker, The bH TCSPC Handbook 4th Edition (Becker \& Hickl GmbH, Berlin, 2010).

101. M. A. Duguay, "The ultrafast optical Kerr shutter" Progress in Optics 14, 161-193 (1976)

102. B. Schmidt, S. Laimgruber, W. Zinth, and P. Gilch, "A broadband Kerr shutter for femtosecond fluorescence spectroscopy" Applied Physics B: Lasers \& Optics 76, 809$814(2003)$

103. M. A. Kahlow, W. Jarzeba, T. P. DuBruil, and P. F. Barbara, "Ultrafast emission spectroscopy in the ultraviolet by time-gated upconversion" Review of Scientific Instruments 59, 1098-1109 (1988) 
104. G. C. Walker, W. Jarzeba, T. J. Kang, A. E. Johnson, and P. F. Barbara, "Ultraviolet femtosecond fluorescence spectroscopy: techniques and applications" J. Opt. Soc. Am. B 7, 1521-1527 (1990)

105. "http://www.univie.ac.at/ultrafast-dynamics/newgraphix/uc1.jpg."

106. V. G. Dimitriev, G. G. Gurzadyan, and D. N. Nikogosyan, Handbook of Nonlinear Optical Crystals 3rd Edition (Springer, Berlin, 1999).

107. M. Nakata, and M. Sakurai, "Refractive index and excess volume for binary liquid mixtures. Part 1.-Analyses of new and old data for binary mixtures" Journal of the Chemical Society, Faraday Transactions 1: Physical Chemistry in Condensed Phases 83, 2449-2457 (1987)

108. M. Friebel, and M. Meinke, "Model function to calculate the refractive index of native hemoglobin in the wavelength range of 250-1100nm dependent on concentration" Applied Optics 45, 2838-2842 (2006)

109. L. E. Nielsen, Predicting the Properties of Mixture: mixture rules in science and engineering (M. Dekker, 1978).

110. C. Gergely, L. Zimányi, and G. Váró, "Bacteriorhodopsin Intermediate Spectra Determined over a Wide pH Range" The Journal of Physical Chemistry B 101, 93909395 (1997)

111. D. Tentori, and J. R. Lerma, "Refractometry by minimum deviation: accuracy analysis" Opt. Eng. 29, 160-168 (1990)

112. E. Korchemskaya, D. Stepanchikov, and T. Dyukova, "Photoinduced anisotropy in chemically-modified films of bacteriorhodopsin and its genetic mutants" Opt. Mater. 14, $185-191(2000)$

113. G. Chen, Y. Yuan, C. Zhang, G. Yang, J. G. Tian, T. Xu, and Q. W. Song, "All-optical time-delay relay based on a bacteriorhodopsin film" Opt. Lett. 31, 1531-1533 (2006)

114. M. Mero, A. Sipos, G. Kurdi, and K. Osvay, "Generation of energetic femtosecond green pulses based on an OPCPA-SFG scheme" Opt. Express 19, 9646-9655

115. "http://www.sandia.gov/pcnsc/departments/lasers/snlo-software.html," (Sandia National Laboratories, 2005).

116. J. T. Verdeyen, Laser Electronics (3rd Edition) (Prentice-Hall, 1995).

117. H. Rhee, and T. Joo, "Noncollinear phase matching in fluorescence upconversion" Opt. Lett. 30, 96-98 (2005)

118. Jean-Claude Diels, and W. Rudolph, Ultrashort Laser Pulse Phenomena 2nd Edition (Academic Press, Boston, 2006). 
119. "http://mathworld.wolfram.com/SingularValueDecomposition.html,"

(Wolfram MathWorld).

120. Z. Heiner, A. Makai, and G. I. Groma, "Ultrafast fluorescence kinetics measurement based on up-conversion method," (COST Meeting \& Training School, Nonlinear Nanophotonics 2010, Visegrád, Hungary).

121. A. Mokhtari, A. Chebira, and J. Chesnoy, "Subpicosecond fluorescence dynamics of dye molecules" J. Opt. Soc. Am. B 7, 1551-1557 (1990)

122. M. Yoshizawa, K. Suzuki, A. Kubo, and S. Saikan, "Femtosecond study of S2 fluorescence in malachite green in solutions" Chemical Physics Letters 290, 43-48 (1998)

123. Y. Kanematsu, H. Ozawa, I. Tanaka, and S. Kinoshita, "Femtosecond optical Kerr-gate measurement of fluorescence spectra of dye solutions" Journal of Luminescence 87-89, 917-919 (2000)

124. A. C. Bhasikuttan, A. V. Sapre, and T. Okada, "Ultrafast Relaxation Dynamics from the S2 State of Malachite Green Studied with Femtosecond Upconversion Spectroscopy" J. Phys. Chem. A 107, 3030-3035 (2003)

125. K. Dobek, "The Influence of Temperature on Coumarin 153 Fluorescence Kinetics" Journal of Fluorescence 21, 1547-1557 (2011)

126. U. Brackmann, Laser Dyes (Lambda Physik AG, Göttingen, Germany, 2000).

127. G. Landl, T. Langthaler, H. W. Englt, and H. F. Kauffmann, "Distribution of event times in time-resolved fluorescence: The exponential series approach-algorithm, regularization, analysis" Journal of Computational Physics 95, 1-28 (1991)

128. J. T. Giurleo, and D. S. Talaga, "Global fitting without a global model: Regularization based on the continuity of the evolution of parameter distributions" The Journal of Chemical Physics 128, 114114-114118 (2008)

129. G. I. Groma, Z. Heiner, A. Makai, and F. Sarlos, "Estimation of kinetic parameters from time-resolved fluorescence data: A compressed sensing approach" RSC Advances 2, 11481-11490 (2012)

130. Y. S. Liu, and W. R. Ware, "Photophysics of polycyclic aromatic hydrocarbons adsorbed on silica gel surfaces. 1. Fluorescence lifetime distribution analysis: an illconditioned problem" The Journal of Physical Chemistry 97, 5980-5986 (1993)

131. E. J. Candes, and M. B. Wakin, "An Introduction To Compressive Sampling" IEEE Signal Process. Mag. 25, 21-30 (2008) 
132. D. L. Donoho, and J. Tanner, "Sparse nonnegative solution of underdetermined linear equations by linear programming" Proceedings of the National Academy of Sciences of the United States of America 102, 9446-9451 (2005)

133. S. Chen, D. Donoho, and M. Saunders, "Atomic decomposition by basis pursuit" SIAM Review J. Sci. Comput. 20, 33-61. (1999)

134. "http://dsp.rice.edu/cs."

135. L. Rover Jr, J. C. B. Fernandes, G. de Oliveira Neto, L. T. Kubota, E. Katekawa, and S. H. P. Serrano, "Study of NADH Stability Using Ultraviolet-Visible Spectrophotometric Analysis and Factorial Design" Analytical Biochemistry 260, 50-55 (1998)

136. "http://refractiveindex.info/."

137. M. Daimon, and A. Masumura, "High-Accuracy Measurements of the Refractive Index and its Temperature Coefficient of Calcium Fluoride in a Wide Wavelength Range from 138 to 2326 nm" Appl. Opt. 41, 5275-5281 (2002)

138. I. H. Malitson, "A Redetermination of Some Optical Properties of Calcium Fluoride" Appl. Opt. 2, 1103-1107 (1963)

139. M. Lorenc, M. Ziolek, R. Naskrecki, J. Karolczak, J. Kubicki, and A. Maciejewski, "Artifacts in femtosecond transient absorption spectroscopy" Appl. Phys. B 74, 19-27 (2002)

140. A. Börzsönyi, Z. Heiner, M. P. Kalashnikov, A. P. Kovács, and K. Osvay, "Dispersion measurement of inert gases and gas mixtures at $800 \mathrm{~nm}$ " Appl. Opt. 47, 4856-4863 (2008)

141. M. Daimon, and A. Masumura, "Measurement of the refractive index of distilled water from the near-infrared region to the ultraviolet region" Appl. Opt. 46, 3811-3820 (2007)

142. I. Z. Kozma, P. Krok, and E. Riedle, "Direct measurement of the group-velocity mismatch and derivation of the refractive-index dispersion for a variety of solvents in the ultraviolet" J. Opt. Soc. Am. B 22, 1479-1485 (2005)

143. C. Zhang, Q. W. Song, C.-Y. Ku, R. B. Gross, and R. R. Birge, "Determination of the refractive index of a bacteriorhodopsin film" Opt. Lett. 19, 1409-1411 (1994)

144. Z. Heiner, and K. Osvay, "Refractive index of dark-adapted bacteriorhodopsin and tris(hydroxymethyl)aminomethane buffer between 390 and 880 nm" Appl. Opt. 48, 4610-4615 (2009)

145. L. Fábián, Z. Heiner, M. Mero, M. Kiss, E. K. Wolff, P. Ormos, K. Osvay, and A. Dér, "Protein-based ultrafast photonic switching" Opt. Express 19, 18861-18870 (2012) 
146. R. A. Mathies, C. H. Brito Cruz, W. T. Pollard, and C. V. Shank, "Direct observation of the femtosecond excited-state cis-trans isomerization in bacteriorhodopsin" Science 240, 777-779 (1988)

147. S. Ruhman, B. X. Hou, N. Friedman, M. Ottolenghi, and M. Sheves, "Following evolution of bacteriorhodopsin in its reactive excited state via stimulated emission pumping" J. Am. Chem. Soc. 124, 8854-8858 (2002)

148. S. Sharkov, A. Pakulev, S. Chekalin, and Y. Matveetz, "Primary events in bacteriorhodopsin probed by subpicosecond spectroscopy" Biochim. Biophys. Acta 808, 94-102 (1985)

149. A. Aharoni, B. Hou, N. Friedman, M. Ottolenghi, I. Rousso, S. Ruhman, M. Sheves, T. Ye, and Q. Zhong, "Non-isomerizable artificial pigments: Implications for the primary light-induced events in bacteriorhodopsin" Biochemistry-Moscow 66, 1210-1219 (2001)

150. A. Biesso, W. Qian, and M. El-Sayed, "Gold nanoparticle plasmonic field effect on the primary stepof the other photosynthetic system in Nature, bacteriorhodopsin" J. Am. Chem. Soc. 130, 3258-3259 (2008)

151. D. W. McCamant, P. Kurkura, and R. A. Mathies, "Femtosecond stimulated Raman study of excited-state evolution in bacteriorhodopsin" J. Phys. Chem. B 109, 1044910457 (2005)

152. J. Dobler, W. Zinth, W. Kaiser, and D. Oesterhelt, "Excited-state reaction dynamics of bacteriorhodopsin studied by femtosecond spectroscopy" Chem. Phys. Letters 144, 215$220(1988)$

153. M. L. Applebury, K. S. Peters, and P. M. Rentzepis, "Primary intermediates in the photochemical cycle of bacteriorhodopsin" Biophysical Journal 23, 375-382 (1978)

154. G. Li, and K. D. Glusac, "The Role of Adenine in Fast Excited-State Deactivation of FAD: a Femtosecond Mid-IR Transient Absorption Study" The Journal of Physical Chemistry B 113, 9059-9061 (2009)

155. Haik Chosrowjan, Seiji Taniguchi, Noboru Mataga, Fumio Tanaka, and A. J. W. G. Visser, "The stacked flavin adenine dinucleotide conformation in water is fluorescent on picosecond timescale" Chemical Physics Letters 378, 354-358 (2003)

156. S. D. M. Islam, T. Susdorf, A. Penzkofer, and P. Hegemann, "Fluorescence quenching of flavin adenine dinucleotide in aqueous solution by $\mathrm{pH}$ dependent isomerisation and photo-induced electron transfer" Chemical Physics 295, 137-149 (2003) 
157. G. Kotowycz, N. Teng, M. P. Klein, and M. Calvin, "The $220 \mathrm{MHz}$ nuclear magnetic resonance study of a solvent-induced conformational change in flavin adenine dinucleotide" Journal of Biological Chemistry 244, 5656-5662 (1969)

158. Z. W. Chen, M. Koh, G. Van Driessche, J. J. Van Beeumen, R. G. Bartsch, T. E. Meyer, M. A. Cusanovich, and F. S. Mathews, "The structure of flavocytochrome c sulfide dehydrogenase from a purple phototrophic bacterium" Science 266, 430-432 (1994)

159. I. H. M. van Stokkum, D. S. Larsen, and R. van Grondelle, "Erratum to "Global and target analysis of time-resolved spectra" "Biochimica et Biophysica Acta (BBA) Bioenergetics 1658, 262 (2004)

160. J. R. Knutson, D. G. Walbridge, and L. Brand, "Decay-associated fluorescence spectra and the heterogeneous emission of alcohol dehydrogenase" Biochemistry 21, 46714679 (1982)

161. D. Zhong, S. K. Pal, D. Zhang, S. I. Chan, and A. H. Zewail, "Femtosecond dynamics of rubredoxin: Tryptophan solvation and resonance energy transfer in the protein" Proceedings of the National Academy of Sciences 99, 13-18 (2002)

162. R. Jimenez, G. R. Fleming, P. V. Kumar, and M. Maroncelli, "Femtosecond solvation dynamics of water" Nature 369, 471-473 (1994)

163. P. A. W. van den Berg, K. A. Feenstra, A. E. Mark, H. J. C. Berendsen, and A. J. W. G. Visser, "Dynamic Conformations of Flavin Adenine Dinucleotide: Simulated Molecular Dynamics of the Flavin Cofactor Related to the Time-Resolved Fluorescence Characteristics" J. Phys. Chem. B 106, 8858-8869 (2002) 